МIНICTЕРСТВО ОСВІТИ І НАУКИ УКРАЇНИ

\title{
НАУКОВИЙ ЧАСОПИС
}

\author{
НАЦІОНАЛЬНОГО ПЕДАГОГІЧНОГО УНІВЕРСИТЕТУ \\ IMЕНІ М. П. ДРАГОМАНОВА
}

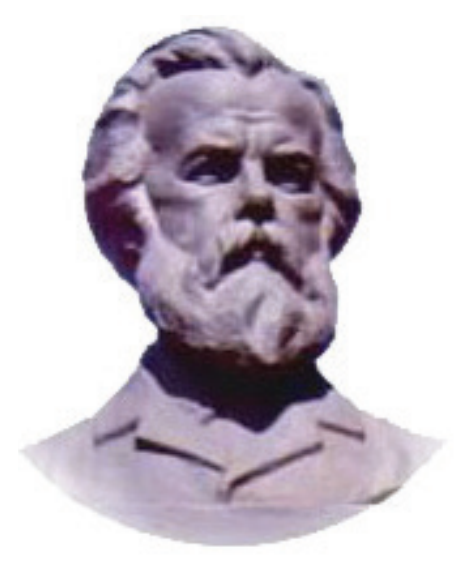

\section{Сepir 18}

\author{
Право
}

Випуск 36

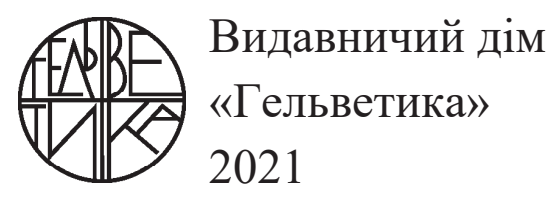




\section{УДК 06}

H 34

Свідоцтво про державну ресстрацію друкованого засобу масової інформації

Серія КВ № 8824 від 01.06.2004 р. (перересстровано - Свідоцтво про державну ресстрацію друкованого засобу масової інформації Серія КВ № 22863-12763ПР від 19.08.2017 р.)

Журнал включено до категорії «Б» Переліку наукових фахових видань України зі спеціальностей 081 - Право, 262 - Правоохоронна діяльність, 293 - Міжнародне право на підставі Наказу МОН України від 09.02.2021 № 157 (додаток 4)

Науковий журнал включено до міжнародної наукометричної бази Index Copernicus International (Республіка Польща)

Статті у виданні перевіряються на наявність плагіату за допомогою програмного забезпечення StrikePlagiarism.com від польської компанії Plagiat.pl.

Офіційний сайт видання: www.chasopys.law.npu.kiev.ua

Схвалено рішенням Вченої ради НПУ імені М. П. Драгоманова (протокол № 6 від 22 грудня 2021 року)

\section{Головний редактор:}

В. Ю. Стеценко - доктор юридичних наук, професор, заслужений діяч науки і техніки України, завідувач кафедри правознавства та галузевих юридичних дисциплін, Національний педагогічний університет імені М. П. Драгоманова.

\section{Редакційна колегія:}

С. В. Агієвєць - кандидат юридичних наук, доцент;

Б. І. Андрусишин - доктор історичних наук, професор;

В. В. Бєлєвцева - доктор юридичних наук, старший науковий співробітник;

К. І. Бєляков - доктор юридичних наук, професор;

Є. В. Білозьоров - кандидат юридичних наук, доцент;

М. Ю. Віхляєв - доктор юридичних наук, доцент;

О. С. Дніпров - доктор юридичних наук;

Ярослав Добковскі - габілітований доктор права, професор;

о. Д. Довгань - доктор юридичних наук, професор;

І. В. Зозуля - доктор юридичних наук, професор;

О. О. Золотар - доктор юридичних наук, старший науковий співробітник;

I. Ф. Корж - доктор юридичних наук, старший науковий співробітник;

М. О. Ларкін - кандидат юридичних наук, доцент;

А. О. Монаєнко - доктор юридичних наук, професор;

Н. М. Опольська - кандидат юридичних наук, доцент;

В. Г. Пилипчук - доктор юридичних наук, професор;

В. В. Тильчик - доктор юридичних наук, доцент;

О. В. Токарчук - доктор юридичних наук, доцент.

НАУКОВИЙ ЧАСОПИС НАЦІОНАЛЬНОГО ПЕДАГОГІЧНОГО УНІВЕРСИТЕТУ ІМЕНІ М. П. ДРАГОМАНОВА. Серія 18. Право. Журнал / М-во освіти і науки України, Нац. пед. ун-т імені М. П. Драгоманова. - Випуск 36. - Одеса: Видавничий дім “Гельветика”, 2021. - 110 с.

У статтях розглядаються актуальні проблеми наукових досліджень докторантів, аспірантів, викладачів вищих навчальних закладів та співробітників наукових установ України, у яких висвітлюються актуальні теоретичні, наукові та науково-методичні проблеми правових наук. 


\author{
УДК 343.985 \\ DOI https://doi.org/10.31392/NPU-nc.series 18.2021.36.01
}

Антощук А. О., Гриненко К. В.

\title{
ОСОБЛИВОСТІ ПРЕД’ЯВЛЕННЯ ОСОБИ ДЛЯ ВПІЗНАННЯ ЗА МАТЕРІАЛАМИ ВІДЕОЗАПИСУ
}

У статті розглядається низка питань, які стосуються тактики проведення такої процесуальної слідчої дії в кримінальному провадженні, як пред'явлення особи для впізнання. Метою статті є розкриття й аналіз особливостей тактики проведення пред'явлення особи для впізнання за матеріалами відеозапису на початковому та подальшому етапах розслідування. Детально розглянуто підготовчий, робочий $і$ заключний етап проведення цієї слідчої (розшукової) дії, а також описано підстави ї̈ проведення та основні завдання, які вирішуються.

Виокремлено й досліджено деякі організачійно-підготовчі заходи щзодо проведення пред 'явлення особи для впізнання за матеріалами відеозапису. Зокрема, роз 'яснюється роль фахівия, який володіє спеціальними знаннями у наданні технічної підтримки під час попереднього допиту особи. А також значну увагу приділено особливостям виготовлення слідчим зразків відеоматеріалів для подальшого проведення впізнання.

У статті наведено приклади судових рімень, у яких докази визнано недопустимими. Зокрема, акцентується увага на проблематиці дотримання належної процедури одержсання доказів та фіксування результатів діï. Зазначено причини порушення умов допустимості доказів під час досудового розслідування та можливості їх усунення. Надано практичні рекомендації щุодо підготовки, проведення та використання результатів пред 'явлення особи для впізнання за матеріалами відеозапису.

Зроблено висновок, що сторона обвинувачення під час здійснення підготовчих заходів, організаuіï його проведення, підбору порівнюваних під час впізнання статистів і використання матеріалів відеозапису має докласти максимальних зусиль для дотримання всіх вимог проведення процесуальної дії відповідно до кримінального прочесуального закону.

Ключові слова: пред'явлення особи для впізнання, матеріали відеозапису, досудове розслідування, тактика, допустимість доказів.

Аналіз досліджень і публікацій. Зазначимо, що темі пред'явлення особи для впізнання присвячували свої наукові роботи Н.М. Ахтирська, Р.С. Бєлкін, О.Я. Гінзбург, М.М. Гопанович, М.О. Головецький, А.В. Дулов, В.А. Колесник, В.О. Коновалова, Г.І. Кочаров, В.Г. Лукашевич, Є.Д. Лук'янчиков, М.В. Салтевський, К.О. Чаплинський, Л.Д. Удалова, В.Ю. Шепітько та інші. Зокрема, цими науковцями розкрито загальну тактику пред’явлення особи для впізнання, однак питання організації і тактики пред’явлення особи для впізнання за матеріалами відеозапису потребують детальнішого висвітлення.

3 огляду на це головною метою статті є аналіз особливостей проведення пред'явлення особи для впізнання за матеріалами відеозапису з урахуванням сучасних потреб правоохоронної практики.

Виклад основного матеріалу. Найбільш ефективною слідчою (розшуковою) дією ідентифікаційного характеру, яку доцільно проводити під час розкриття та розслідування будь-якої категорії кримінальних правопорушень (чи то злочин проти життя та здоров’я особи, наприклад вбивство або умисне тяжке тілесне ушкодження, чи проти власності, наприклад крадіжка, грабіж, розбій тощо), $є$ пред'явлення для впізнання. Розкриваючи значення впізнання в процесі доказування, М.С. Строгович вказував на те, що цей прийом відомий протягом тисячоліть, він існував у кримінально-процесуальних системах усіх часів і народів [8, с. 318].

Проведення пред'явлення особи для впізнання як слідча (розшукова) дія полягає в пред’явленні свідкові, потерпілому або іншій особі для впізнання іншої особи. Це здійснюється з метою встановлення тотожності або відмінності цієї особи від тої, яка спостерігалася раніше, збереглась у пам'яті і про яку така особа давала показання.

Відповідно до ч. 6 ст. 228 КПК України за необхідності впізнання може проводитися за фотознімками та матеріалами відеозапису з додержанням вимог, зазначених у частинах першій 
і другій цієї статті. Проведення впізнання за фотознімками, матеріалами відеозапису виключає можливість подальшого пред’явлення особи для впізнання [5].

Необхідність пред'явлення особи для впізнання за матеріалами відеозапису виникає в тих випадках, коли особу, яка підлягає впізнанню, треба показати в русі, відтворюючи ситуацію, в якій ії спостерігали, але безпосереднє пред'явлення особи або неможливе (наприклад, підозрюваний або обвинувачений зник або місце його знаходження не встановлено з інших причин), або недоцільне в інтересах особи, яка впізнає (з метою дотримання безпеки впізнаючого за умови, коли існує загроза його життю або здоров'ю з боку підозрюваного або обвинуваченого).

Крім того, відеозапис залишається нині єдиним засобом, що дозволяє зафіксувати ознаки динамічних елементів зовнішнього вигляду людини.

Однак пред'явлення для впізнання за матеріалами відеозапису має свої тактичні особливості. Криміналістичної тактикою передбачені такі стадії проведення слідчої дії, як:

- підготовка до слідчої (розшукової) дії - підготовчий етап;

- безпосереднє проведення слідчої (розшукової) дії - робочий етап;

- оформлення результатів слідчої (розшукової) дії - заключний етап.

Говорячи про тактичні прийоми застосування спеціальних знань під час проведення пред'явлення особи для впізнання за матеріалами відеозапису, слід приділити увагу такому питанню, як залучення фахівця для участі в цій слідчій (розшуковій) дії. Спеціаліст, володіючи спеціальними знаннями у сфері габітології і портретної експертизи, відеотехніки, може надати істотну допомогу слідчому на всіх етапах проведення пред'явлення особи для впізнання за матеріалами відеозапису.

Результати правозастосовчої практики засвідчують, що слідчі не завжди проводять допит за участю спеціаліста й не використовують можливість отримання відповідної консультації, коли в цьому постає об'єктивна необхідність. Зазначене призводить до зниження ефективності допиту, втрати доказової інформації та слідчих помилок. У зв'язку з цим ми пропонуємо тактичні рекомендації, спрямовані на удосконалення етапів проведення пред'явлення особи для впізнання за матеріалами відеозапису.

Одним з обов'язкових елементів підготовчого етапу пред'явлення особи для впізнання за матеріалами відеозапису є допит особи, якій необхідно пред'явити відеозапис. Допит $\epsilon$ обов'язковою умовою проведення впізнання [1, с. 67]. Можна погодитися 3 думкою Є.Д. Лук'янчикова та О.М. Моісєєва, які вважають, що попередній допит потерпілих (свідків) є не тільки необхідним етапом у підготовці до пред'явлення для впізнання, а ще й обставиною, яка забезпечує прийняття правильного рішення про доцільність проведення цієї слідчої дії, її успішний процес, отримання належних результатів та їх подальшу оцінку [6, с. 30].

Під час допиту слідчому слід задавати питання спеціального характеру:

1) чи може допитуваний впізнати особу за ознаками зовнішнього вигляду в разі ії̈ пред'явлення для впізнання за матеріалами відеозапису;

2) за якими конкретно ознаками допитуваний може впізнати пред'явлене йому обличчя на відеозаписі:

а) комплексними (антропологічний тип, зріст, статура, вік);

б) динамічними (хода, жестикуляція, артикуляція, постава);

в) анатомічними (форма голови, волосяний покрив голови, особливості шкірного покриву, ознаки брів, очей, носа, підборіддя тощо) [4, с. 2].

Ці питання фахівець може роз'яснити слідчому в індивідуальному порядку в межах консультації або безпосередньо під час проведення допиту особи, що впізнаватиме, що, на наш погляд, $\epsilon$ найбільш прийнятним і доцільним.

Діяльність фахівця в цьому разі буде спрямована на повний та професійний опис ознак зовнішності людини, яку раніше спостерігав впізнаючий, зі спеціальною термінологією і певною послідовністю: зверху вниз, від загального до конкретного. Роль фахівця у процесі допиту повинна зводитися до активізації пам'яті допитуваної особи з уявного образу, і тому доцільно 
використовувати інформаційно-довідкову літературу, а також спеціальні альбоми, що містять типи й елементи зовнішності.

При цьому слідчий не повинен обмежуватися певними ознаками зовнішнього вигляду і його особливостями (прикметами), а результати, отримані на допиті, повинні бути проаналізовані фахівцем з погляду достатності ознак зовнішнього вигляду для проведення пред'явлення для впізнання.

Забороняється заздалегідь показувати впізнаючому особу, яка підлягає впізнанню (натурально, за фотознімками або відеозображеннями), або повідомляти ії ознаки.

Однак на практиці бувають такі випадки, коли слідчий попередньо показує відео $з$ камер спостереження за участю особи, яка підлягатиме впізнанню, і такі протоколи пред’явлення особи для впізнання в подальшому визнаються недопустимим доказом.

Наведемо приклад: «Так, із матеріалів провадження вбачається, що під час розгляду суду першої інстанції судом було досліджено основні докази обвинувачення - протоколи пред'явлення особи для впізнання від 19.12.2016 року та від 23.12.2016 року за участю свідка ОСОБА_3 , який у ході цієї слідчої дії повідомив, що зможе впізнати особу, яка 20.08.2016 року спричинила тілесні ушкодження ОСОБА_2, та серед інших осіб впізнав ОСОБА_1.

Проте перевіркою матеріалів провадження встановлено, що перед пред'явленням особи для впізнання слідчий показував ОСОБА_3 відео з камер спостереження кафе-бару «Наталі» за участю ОСОБА_1, тобто фактично провів впізнання за матеріалами відеозапису, що підтвердив і свідок ОСО̄БА_3 безпосередньо у судовому засіданні.

Так, відповідно до ч. 1 ст. 228 КПК забороняється попередньо показувати особі, яка впізнає, особу, яка повинна бути пред'явлена для впізнання, та надавати інші відомості про прикмети цієї особи. Вказана вимога закону пояснюється врахуванням властивостей людської психіки, оскільки краще запам'ятовується і відтворюється той образ людини, що сприйнятий пізніше.

Також у ч. 6 ст. 228 КПК передбачено, що проведення впізнання за фотознімками, матеріалами відеозапису виключає можливість у подальшому пред'явленні особи для впізнання. Крім того, $\epsilon$ неприпустимим також проводити повторне пред'явлення особи для впізнання тому самому впізнаючому та за тими самими ознаками» [7].

На підготовчому етапі слідчому необхідно вивчити відеозапис, який підлягає пред'явленню для впізнання, а також здійснити підбір відеозаписів, серед яких буде здійснюватися пред'явлення для впізнання, якщо на досліджуваному відеозаписі відсутні особи, схожі зі впізнаваною особою. При цьому, залучаючи фахівця, слідчому необхідно отримати інформацію, спрямовану на виявлення факторів, що впливають на повноту і достовірність відображення ознак зовнішності на відеозаписі, визначити якість відеозапису шляхом встановлення різкості, контрастності, типу і характеру освітлення, ракурсу і дистанції зйомки, технічних параметрів відеокамери, а також відповідність розмірних характеристик на відеозаписі з розмірними характеристиками особи в натурному вигляді.

Спеціаліст повинен роз'яснити слідчому, а також допитуваній особі, що на відеозаписі певним чином змінюються або спотворюються ознаки зовнішнього вигляду (наприклад, через освітлення частина елементів може не відобразитися; зріст людини і пропорції різних елементів зовнішності зменшуються, а за наявності перспективних спотворень відеокамери зображення може «витягуватися», тим самим змінюючи елементи зовнішності по довжині і ширині). Також слід встановити, що пропонований для впізнання матеріал відеозапису є оригіналом або копією [4, с. 3$]$.

Під час підготовки пред'явлення для впізнання слідчий у присутності фахівця вибирає той кадр відеозапису, де без істотних змін і викривлень найбільш повно і достовірно відобразилися ознаки зовнішнього вигляду особи, що пред'являється для впізнання.

Відповідно до ч. 7 ст. 228 КПК матеріали відеозапису із зображенням особи, яка підлягає впізнанню, можуть бути пред'явлені лише за умови зображення на них не менше чотирьох осіб, які повинні бути тієї ж статі і не повинні мати різких відмінностей у віці, зовнішності та одязі з особою, яка підлягає впізнанню [5]. 
Недотримання цих вимог призводить до визнання доказу недопустимим. Прикладом є ухвала Апеляційного суду Закарпатської області від 6 вересня 2016 року у справі № 299/2594/15 (провадження № №11-кп/777/375/16).

В апеляційній скарзі захисник вважає, що неналежними доказами у справі є протоколи пред'явлення потерпілим та свідкам особи для впізнання за відеозаписами, оскільки така слідча дія проведена з порушенням ст. 228 КПК України, та зазначає, що для впізнання потерпілим і свідкам надано відеозаписи з різних магазинів, які невідомо де вилучені та які не визнані речовими доказами у справі.

Як убачається з матеріалів кримінального провадження, зокрема із протоколів пред'явлення особи для впізнання за відеозаписами від 13.08.2015, 14.08.2015, 15.08.2015, 18.08.2015, вимоги ч. 7 ст. 228 КПК України слідчим не дотримані, а судом першої інстанції належним чином не перевірені, а тому ці докази є неналежними та недопустимими, і вони підлягають виключенню із мотивувальної частини вироку як докази винуватості обвинуваченого у вчиненні інкримінованих йому злочинів [9].

Саме тому в такому разі доцільно використовувати матеріали відеозапису, що зберігаються в відеотеці органу досудового розслідування або отримані в процесі проведення різних слідчих (розшукових) дій (наприклад, слідчий експеримент). Використовуючи дані відеотек, у протоколі необхідно зафіксувати прізвище, ім'я, по батькові особи, яка підлягає впізнанню.

У тому разі, коли на певному відеокадрі знаходиться кілька осіб, серед яких є особа, що підлягає впізнанню, необхідність у виготовленні додаткових відеозаписів відсутня. При цьому треба враховувати, що ці особи повинні бути зовні подібними між собою.

У такому разі під час підбору відеозаписів, що пред'являються для впізнання, необхідно відбирати ті, на яких є збіги в осіб деяких комплексних (зріст, статура, вік, антропологічний тип) і анатомічних ознак (наприклад, колір, густота і довжина волосяного покриву, наявність вусів, бороди, бакенбардів або лисини). Також видається доцільним здійснювати підбір відеозаписів з відображенням однакових супутніх ознак (одяг і різні аксесуари).

Що ж стосується динамічних ознак, то тут необхідно зазначити, що досягти їх збігу - досить складне завдання, але цілком реалізоване, про що говорилося вище (наприклад, під час підбору людей з певними особливостями ходи можна залучати пацієнтів з ортопедичних або травматологічних центрів).

У разі, коли необхідно виготовити додаткові відеозаписи самостійно, слідчий повинен дотримуватися певних правил. По-перше, для проведення запису відеоматеріалу слід мати приміщення площею приблизно 30 м², з достатнім освітленням та нейтрально-сірим фоном. По-друге, на стіні (фоні) необхідно закріпити номер, за яким особу пред’являтимуть для впізнання, а навпроти слід встановити відеокамеру на штативі.

Відеозапис починається з того, що слідчий пропонує особі, яка підлягає впізнанню, підійти до стіни з номером і стати обличчям до камери. У подальшому оператор збільшує план зйомки так, щоб у кадрі опинилось зображення особи по груди (тривалість зйомки - 20 с), а потім так, щоб у кадрі була лише голова (20 c).

Якщо особа, яка буде впізнавати, під час допиту зазначила певні особливості міміки, то слідчий повинен поставити декілька запитань на сторонні теми або ж дати особі прочитати будь-який текст. Після цього слідчий пропонує особі повернути голову ліворуч (тривалість зйомки - 10 c), праворуч (10 c), а також поглянути на камеру (10 c).

Під час відеозапису процесу впізнання за динамічними ознаками (наприклад, за особливостями ходи) осіб, яких пред’явлено для впізнання, варто розташувати їх у ряд і знімати спочатку всіх разом, а потім кожну особу окремо для забезпечення можливості порівняння ходи. При цьому враховують показання особи, яка впізнає, щодо того, в якому ракурсі вона сприймала об’єкт впізнання (наприклад, якщо особа, яка впізнає, спостерігала людину, що стояла до неї боком, то група осіб, серед яких знаходиться особа, яка підлягає впізнанню, повинна рухатися по колу, а відеокамера - знаходитися у його центрі). 
Організатор слідчої дії пропонує особі, яка підлягає впізнанню, пройтися, не кваплячись, кілька разів уздовж стіни (праворуч і ліворуч на дистанції 5-10 м), спостерігаючи за тим, щоб вона не виходила за межі кадру [3, с. 106].

Безпосереднє пред'явлення особи для впізнання за матеріалами відеозапису, тобто робочий етап цієї слідчої (розшукової) дії, включає в себе загальні правила.

Зазначений етап слідчої дії можна проводити в будь-якому службовому приміщенні (зазвичай його проводять у кабінеті слідчого). Для демонстрації відеозапису може бути використаний будь-який телевізор 3 підключеним програвачем або монітор персонального комп’ютера. Участь у цьому етапі беруть слідчий, спеціаліст (у разі потреби), особа, яка впізнає, поняті.

Насамперед слідчий повідомляє про те, яка слідча (розшукова) дія проводиться, іiі цілі, технічні засоби, які буде використано. До протоколу вносять відповідні реквізити: дату, місце проведення слідчої дії, відомості про іiі учасників, роз'яснюють їм їхні права та обов'язки. Учасникам пред'являють пакет із відеоносієм для того, щоб вони переконалися у цілісності пакування [2].

Після цього слідчий або спеціаліст демонструє учасникам слідчої дії відеозапис осіб, які підлягають пред'явленню для впізнання за матеріалами відеозапису, і в особи, яка впізнає, з'ясовують, чи впізнає вона кого-небудь з осіб, чиї відеозображення їй продемонстровано. У разі позитивного результату всім присутнім оголошують зміст довідки, доданої до відеоносія, про що роблять відповідний запис у протоколі слідчої дії. Відеоносій із довідкою долучають до протоколу пред'явлення особи для впізнання за матеріалами відеозапису як додаток.

Заключний етап пред'явлення для впізнання передбачає прийняття рішення про закінчення пред'явлення особи для впізнання, фіксацію ходу і результатів пред'явлення особи для впізнання, оцінку результатів пред'явлення особи для впізнання.

3 огляду на велику складність і специфіку пред'явлення для впізнання особи за iï динамічним ознаками, особливо якщо таке впізнання відбувається за матеріалами відеозапису, доцільна додаткова фіксація ходу і результатів цієї слідчої дії поряд зі складанням протоколу за допомогою відеозапису.

Обов'язково в протоколі пред'явлення особи для впізнання за матеріалами відеозапису необхідно вказати:

- особу, яку було впізнано свідком (потерпілим) на пред'явленому йому матеріалі відеозапису;

- вид та найменування відео відтворювального пристрою (наприклад, відеоплеєр), порядковий номер матеріалів відеозапису і формат відеозапису;

- опис фрагмента (фрагментів) відеозапису, на якому відображено особу, яка пред’являється для впізнання;

- час відеозапису, в момент якого було встановлено факт впізнання.

Крім цього, у протоколі необхідно точно описати ознаки зовнішнього вигляду особи, за якими її впізнали.

Ця слідча (розшукова) дія, як свідчить практика, майже не проводиться, незважаючи на певні іiі переваги, зокрема можливість пред'явлення для впізнання матеріалів відеозапису замість особи безпосередньо. Під час перегляду такого відеозапису створюють умови, близькі до безпосереднього ознайомлення з особою, тому результативність цієї слідчої (розшукової) дії $є$ підвищеною порівняно зі впізнанням за фотознімками.

Висновки. Підсумовуючи вищевикладене, варто зазначити, що аналіз судової практики показує, що під час проведення пред’явлення особи для впізнання слідчі припускаються помилок як процесуального, так і тактичного характеру, що призводить до втрати доказів.

Найчастіше такі помилки пов'язані із прорахунками у здійсненні комплексу підготовчих заходів, організації його проведення, підборі порівнюваних під час впізнання статистів і використанні матеріалів відеозапису, тактичних прийомів проведення цієї слідчої(розшукової) дії, а тому сторона обвинувачення має докласти максимальних зусиль для дотримання всіх вимог проведення процесуальної дії відповідно до кримінального процесуального закону. 


\section{Використана література:}

1. Возгрин И.А., Иванов И.И., Кузьминых К.С. и др. Криминалистика. Схемы и терминология: Учеб. пособ. / Под ред. И.А. Возгрина, В.П. Сальникова, К.И. Сотникова. 2-е изд., испр. СПб., 2000.

2. Жирко В.В. Відеозапис слідчих дій : метод. реком. Дніпропетровськ : Розмножувальний центр УМBC, 2004. $28 \mathrm{c}$.

3. Жирко В.В. Тактика проведення впізнання особи за матеріалами відеозапису. Криміналістичний вісник. №1 (21). 2014. с. 104-107 URL: http://elar.naiau.kiev.ua/jspui/handle/123456789/1954

4. Ильин Н.Н. Предъявление лица для опознания по видеоизображениям: тактические особенности // Вестник ВИ МВД России. 2013. №2. URL: https://cyberleninka.ru/article/n/predyavlenielitsa-dlya-opoznaniya-po-videoizobrazheniyam-takticheskie-osobennosti

5. Кримінальний процесуальний кодекс України від 13 квітня 2012 р. (зі змінами). URL: http://zakon2.rada.gov.ua/laws/show/4651-17.

6. Лук'янчиков Є.Д., Моісєєв О.М. Пред’явлення для впізнання: навчальний посібник. Макіївка, 1998. $104 \mathrm{c}$

7. Постанова Верховного Суду колегії суддів Другої судової палати Касаційного кримінального суду від 02 лютого 2021 року у справі № 366/1365/17, провадження № 51-5752км19. Сдиний державний реєстр судових рішень: [сайт]. URL: https://reyestr.court.gov.ua/Review/94738005

8. Строгович М.С. Курс советского уголовного процесса. Москва: Изд-во Академии наук СССР, $1958.704 \mathrm{c}$.

9. Ухвала Апеляційного суду Закарпатської області від 06 вересня 2016 року у справі № 299/2594/15, провадження № 11-кп/777/375/16. Сдиний держсавний реєстр судових рішень: [сайт]. URL: https://reyestr.court.gov.ua/Review/61219058

\section{References:}

1. Vozgrin I.A.. Ivanov I.I.. Kuzminykh K.S. (2000). Kriminalistika. Skhemy i terminologiya [Forensic science. Schemes and terminology]. 2nd ed. Saint Petersburz, 165 p. [in Russian].

2. Zhyrko V.V. (2004). Videozapys slidchykh dii [Video of investigative actions]. Dnipropetrovsk, Rozmnozhuvalnyi tsentr Upravlinnia ministerstva vnutrishnikh sprav, 28 p. [in Ukrainian].

3. Zhyrko V.V (2014). Taktyka provedennia vpiznannia osoby za materialamy videozapysu [Tactics of presentation a person for identification by video materials]. Forensic Bulletin, vol. 1, no. 21, pp. 104-107. Retrieved from: http://elar.naiau.kiev.ua/jspui/handle/123456789/1954 [in Ukrainian].

4. Ilin N. N. (2013). Predyavleniye litsa dlya opoznaniya po videoizobrazheniyam: takticheskiye osobennosti [Presentation a person for identification by video images: tactical features]. The bulletin of Voronezh Institute of the Ministry of Internal Affairs of Russia, no 2. Retrieved from: https://cyberleninka.ru/article/n/predyavlenie-litsa-dlya-opoznaniya-po-videoizobrazheniyam-takticheskie-osobennosti [in Russian].

5. Verkhovna Rada of Ukraine (2012). Kryminalnyi protsesualnyi kodeks Ukrainy vid 13.04.2012 № 4651VI [Criminal Procedure Code of Ukraine of April 13, 2012 № 4651-VI]. Ofitsiinyi visnyk Ukrainy. Retrieved from: http://zakon2.rada.gov.ua/laws/show/4651-17 [in Ukrainian].

6. Lukianchykov Ye.D., Moisieiev O.M. (1998). Prediavlennia dlia vpiznannia [Presentation for identification]. Makiivka, 104 p. [in Ukrainian].

7. The Supreme Court of Ukraine (2021). Postanova Verkhovnoho Sudu kolehii suddiv Druhoi sudovoi palaty Kasatsiinoho kryminalnoho sudu vid 02 liutoho 2021 roku u spravi № 366/1365/17, provadzhennia № 51-5752km19 [Resolution of the Supreme Court of the panel of judges of the Second Judicial Chamber of the Criminal Court of Cassation of February 2, 2021 in case № 366/1365/17, proceedings № 51-5752km19]. Yedynyi derzhavnyi reiestr sudovykh rishen. Retrieved from: https://reyestr.court.gov.ua/Review/94738005 [in Ukrainian].

8. Strohovych M.S. (1958). Kurs sovetskogo ugolovnogo protsessa [Course of Soviet Criminal Procedure]. Moscow, USSR Academy of Sciences, 704 p. [in Russian].

9. Court of Appeal (2016). Ukhvala Apeliatsiinoho sudu Zakarpatskoi oblasti vid 06 veresnia 2016 roku u spravi № 299/2594/15, provadzhennia № 11-kp/777/375/16 [Decision of the Court of Appeal of the Zakarpattia region of September 6, 2016 in the case № 299/2594/15, proceedings № 11-kp / 777/375/16]. Yedynyi derzhavnyi reiestr sudovykh rishen. Retrieved from: https://reyestr.court.gov.ua/ Review/61219058 [in Ukrainian]. 
Antoshchuk A. O., Hrynenko K. V. Features of presentation a person for identification by video materials

The article deals with a number of issues related to the tactics of conducting such procedural investigative action in criminal proceedings, as presentation a person for identification. The purpose of the article is to disclosure and analyzes the peculiarities the tactics of presentation a person for identification by video materials at the initial and subsequent stages of the investigation. The preparatory, work and final stage of this investigative (search) action are considered in detail, as well as the grounds for its implementation and the main tasks to be solved are described.

Some organizational and preparatory measures for presentation a person for identification by video materials have been identified and researched. In particular, the role of a specialist with expertise in providing technical support during a preliminary interview is explained. And also considerable attention is paid to features of production by investigators of samples of video materials for the further carrying out of identification.

The article provides examples of court decisions in which evidence was declared inadmissible. In particular, attention is focused on the issue of compliance with the proper procedure for obtaining evidence and recording the results of action. The reasons for violation of the conditions of admissibility of evidence during the pre-trial investigation and the possibility of their elimination are indicated. Practical recommendations are provided for the preparation, conduct and use of the results of the presentation a person for identification by video materials.

It is concluded that the prosecution should make every effort to comply with all the requirements of the procedural action in accordance with the criminal procedure law during the preparatory activities, organization of its conduct, selection of comparable extras during identification and use of video materials.

Key words: presentation a person for identification, video materials, pre-trial investigation, tactics, admissibility of evidence. 
УДК 340.11

DOI https://doi.org/10.31392/NPU-nc.series 18.2021.36.02

Бліхар М. М.

\section{ПУБЛІЧНИЙ ІНТЕРЕС В АДМІНІСТРАТИВНОМУ ПРАВІ}

Стаття присвячена дослідженню особливостей публічного інтересу в адміністративному праві. Простежено, що в адміністративному праві встановлена реальна правова можливість оскаржити в суді будь-який акт управління, якщз він порушує чи може порушувати права $і$ свободи фізичних чи юридичних осіб. 3 огляду на ие в контексті обговорення проблеми публічних інтересів в адміністративному праві потрібно наголосити на такій адміністративно-процесуальній функиї правових актів публічного управління, як оскарження через суд незаконних дій та рішень державної і місиевої адміністрації, щзо не відповідають публічному інтересу суб'єктів правовідносин. У такому разі можна виокремити правоохоронну функиію адміністративного права. Адже інтереси соиіальної спільноти визначаються державою як публічні інтереси; право покликане забезпечити їх реалізацію та сприяти через ичей публічний інтерес розвитку соціальної спільноти. Доведено, щз не варто відкидати і важливість забезпечення за допомогою правових механізмів не тільки публічних інтересів, а й приватних, хоча багато дослідників теорії адміністративного права наголошують саме на покликанні адміністративного права формувати, висловлювати, захищати $і$ забезпечувати публічні інтереси. Обгрунтовано, щзо від вибраного засобу захисту публічного інтересу та його якості залежить доцільність та обгрунтованість адміністративного правового регулювання, щзо своєю чергою впливає на корисність і важливість адміністративних та адміністративно-процесуальних актів у процесі забезпечення публічних інтересів конфліктуючих сторін. А реалізація зазначених повноважень в адміністративному акті полягає в конкретній послідовності дій, визначених прочедурою контрольного адміністративного провадження.

Ключові слова: публічний інтерес, правові механізми, адміністративно-правове регулювання, адміністративно-правовий захист, публічне адміністрування, суспільно-правові відносини, право, правовідносини, адміністративне право.

У системі адміністративно-правового регулювання перевага віддається формуванню та реалізації публічних інтересів спільнот. Проте, на мою думку, часто важко відділити приватноправові та публічно-правові інтереси, що встановлюються в нормі вітчизняного адміністративного права. Наприклад, Н.Д. Дячук, досліджуючи поняття адміністративно-правового захисту, вказує на плюралізм думок щодо юридичної природи адміністративно-правового механізму забезпечення прав та інтересів суб'єктів правовідносин. Так, залежно від рівня важливості охоронюваних правовідносин дослідниця виділяє три рівні захисту [4, с. 157-160]: 1) адміністративно-правовий захист - активні дії органів публічного управління (публічної влади), що здійснюються на відновлення порушених законних інтересів, прав та свобод фізичних, юридичних осіб, зняття засобами адміністративного, адміністративно-процесуального права перешкод щодо їх здійснення, зокрема застосування заходів адміністративного примусу та вимоги правової відповідальності (адміністративної зокрема); 2) адміністративно-правова охорона у вузькому розумінні - використання превентивної функції адміністративного права для запобігання адміністративному правопорушенню (його профілактики) чи унеможливлення створення перешкод публічною адміністрацією стосовно прав, свобод та реалізації законних публічних інтересів відповідних суб' єктів суспільно-правових відносин; 3) адміністративноправова охорона в широкому розумінні - це система елементів адміністративно-правового захисту публічного інтересу та його правової охорони у вузькому розумінні, тобто сукупність актів публічної влади, які можуть набувати форми статичної чи динамічної діяльності і здійснюються на основі певних адміністративно-правових норм.

Публічні інтереси можуть стосуватися різних сфер суспільних відносин, і тому серед регламентації правових режимів публічних інтересів можна виокремити кілька видів адміністративного регулювання публічних інтересів, що спрямовані на забезпечення: публічних інтересів стосовно діяльності держави; публічних інтересів стосовно діяльності органів виконавчої 
влади; захисту порядку публічного управління; прав і публічних інтересів територіальних громад і громадян; захисту особи, охорони особистих і громадянських прав і свобод, охорони здоров'я громадян, реалізації публічних інтересів в економічній, соціальній, культурній, екологічній та іншій суспільній діяльності; санітарно-епідемічного благополуччя населення, охорони праці, захисту суспільної моральності, охорони довкілля; інтересів державної безпеки та охорони громадського порядку; інтересів додержання митного режиму перетину кордону; інтересів охорони державних кордонів, усіх соціальних цінностей, які захищаються законом.

Сюди ж можна зарахувати публічний інтерес щодо забезпечення безперешкодного здійснення чи реалізації публічних прав, таких як право на публічну службу, на формування владних повноважень і влади, а також діяльності органів публічної адміністрації у площині правового дотримання принципів верховенства права, законності, прозорості, гласності, ефективності під час розгляду та вирішення адміністративного провадження.

Адміністративне право забезпечує реалізацію публічного інтересу учасників суспільноправових відносин за допомогою прийняття (видання) конкретного правового акту управління (адміністративного акту). При цьому основним критерієм для обгрунтування розроблення й ухвалення певного адміністративного акту для управлінця, який займається правозастосовною діяльністю, є саме публічний інтерес, який при цьому виникає і вимагає правоохоронного рішення [2, с. 43-44].

Загалом категорія «публічний інтерес» є відносно новою. Це загальновизнані потреби держави, територіальної громади, суспільства, що залежать від напрямів державотворення відповідного історичного етапу, цілей, завдань і цінностей, які закріплені в конституції держави, а також загальновизнаних у світі цінностей, що забезпечують збереження цілісності та розвитку суспільства та держави [10, с. 457].

Адміністративне право у своєму розпорядженні має достатньо правових засобів для встановлення і забезпечення публічного інтересу, таких як: нормативне встановлення публічного інтересу та зазначення його ознак; закріплення видів публічних інтересів; визначення пріоритету публічних інтересів; встановлення порядку та гарантій забезпечення публічних інтересів; визначення засобів захисту публічних інтересів і міри адміністративної відповідальності за їх порушення [6, с. 88].

Адміністративний акт тоді відповідатиме публічним інтересам, коли буде вибрана й обгрунтована доцільність його прийняття, корисність із погляду публічних інтересів, відповідність реаліям суспільних відносин, комплексність у вирішенні питань, що становлять публічний інтерес, своєчасне прийняття необхідного адміністративного акта, що значною мірою залежить від кваліфікації і професіоналізму посадових осіб, котрі беруть участь у їх розробленні.

На думку М.В. Шиленка, варто звернути увагу, що адміністративно-правова охорона (захист) має подвійну правову природу залежно від того, в якій правовій площині розглядається ця категорія. 3 погляду публічного права суб'єкти публічної влади зобов'язані захищати суб'єктів суспільно-правових відносин, їхні права та законні інтереси, але коли одна зі сторін цих суспільних правовідносин порушує, наприклад, антимонопольне, податкове, екологічне чи інший вид законодавства, порушує права споживачів, вони уповноважені застосувати щодо порушників заходи адміністративного примусу. Проте, як зауважує дослідник, з погляду приватного права суб'єкти публічної адміністрації під час професійної діяльності не можуть втручатися в саму господарську діяльність суб'єктів господарювання, а тому в адміністративноправовій площині потрібно забезпечувати захист суб'єктів господарювання від незаконного перешкоджання суб' єктами публічної адміністрації їхній виробничо-господарської діяльності [11, c. 1192].

Правовою підставою для застосування адміністративної відповідальності у сфері порушення публічного інтересу є юридичний факт скоєння адміністративного проступку, тобто наявність у діях правопорушника складу адміністративного делікту щодо публічного інтересу, який розглядається. Визначити специфічні риси адміністративного правопорушення, що відрізняють його від інших порушень публічних інтересів, можна за допомогою дослідження його структури, зокрема таких елементів адміністративного правопорушення, як його об'єкт, 
об'єктивна сторона, суб'єкт та суб'єктивна сторона. Об'єкт порушення публічного інтересу можна визначити як адміністративний проступок, тобто порушення функціонування певної групи суспільних відносин, яким цей адміністративний проступок завдає шкоду або створює таку загрозу [8, с. 4].

Водночас, оскільки об'єктом правопорушення виступає публічний інтерес, потрібно додати, що правовідносини, які порушуються цим адміністративним проступком, повинні входити до потенційної сфери реалізації конкретного публічного інтересу, тобто об'єктом адміністративного правопорушення публічного інтересу є його об'єктивація у формі окремих суспільних відносин. Водночас адміністративно-правовий захист публічного інтересу здійснюється у вигляді підтримки усталеного правового функціонування зазначених публічних відносин шляхом заборони певних видів поведінки під загрозою адміністративного покарання, завдяки чому окреслюються межі допустимої та вказуються форми неправомірної поведінки.

Отже, особливість адміністративно-правових засобів захисту публічного інтересу полягає в необхідності скоординованого розгляду діяльності публічних інституцій, часто різних гілок влади щодо реалізації публічного інтересу. Зміст захисту публічного інтересу в контексті його правового забезпечення органами публічної влади (публічної адміністрації) полягає в можливості реалізації суспільних та особистісних потреб незалежно від сфери адміністрування.

Також слід зауважити, що останнім часом у правовідносинах простежуються процеси дерегуляції значної частини суспільних відносин. Особливо характерно це для сфери публічного права, якій властиві такі риси, як владний характер та імперативність правочинів. 3 огляду на суспільні демократичні та економічні виклики стосовно публічних інтересів, реформування правової системи на демократичних і цивілізаційно-культурних, правових засадах, а також зважаючи на значне зростання кількості ситуацій, для вирішення яких часто потрібно застосовувати індивідуальний підхід, держава в особі їі державних органів чи посадових осіб дедалі частіше вимушена та намагається враховувати публічні інтереси інших сторін суспільних відносин, що вимагає від неї деякою мірою узгоджувати владні рішення із суб'єктами економічної діяльності, а це дає змогу ухвалювати владні рішення у вигляді договору із взаємними правами та обов’язками стосовно публічного інтересу, який ці рішення можуть зачіпати.

Оскільки правовий договір слугує універсальним засобом правового регулювання певного суспільного явища, він застосовується як форма правового документа в більшості галузей права, зокрема й адміністративного, будучи одним із джерел правочину. Тому можна вести мову про активну правову практику оформлення договірних відносин у публічному адмініструванні, тобто про активне взаємопроникнення публічного і приватного права.

Договори у сфері публічного адміністрування стають звичним правовим явищем у діяльності суб'єктів права. Щоправда, інститут договору в публічному праві загалом і в адміністративному праві зокрема не можна вважати аналогом для ідентичної правової категорії у приватному праві, тому варто здійснити порівняльний аналіз договірних конструкцій у різних сферах права, зокрема в адміністративному праві.

Стосовно сучасної теорії адміністративно-процесуального права захист публічного інтересу може бути здійснений під час: конфліктного адміністративного процесу, тобто через діяльність суб'єкта публічної адміністрації, зокрема адміністративних органів та органів судової влади, в тому числі через правову діяльність адміністративних судів та судів загальної юрисдикції щодо вирішення публічно-правового спору; судового адміністративного процесу, здійсненого через діяльність органів судової влади, зокрема через правову діяльність адміністративних судів та судів загальної юрисдикції з розгляду та вирішення публічно-правових спорів відповідно до порядку, визначеного Кодексом адміністративного судочинства України та Кодексом України про адміністративні правопорушення; сервісного адміністративного процесу, якщо діяльність органів публічної адміністрації $є$ неконфліктною, що проявляється у вирішенні публічного інтересу через індивідуально-конкретні справи фізичної або юридичної особи за ії зверненням.

Підсумовуючи, доцільно констатувати, що публічний інтерес об'єктивно наявний у суспільстві, тобто передумовою для його існування є необхідність встановлення пріоритетності при- 
родних потреб суспільства. Його задоволення має важливе значення для всього суспільства як сукупності (широкого кола) суб'єктів чи значного кола учасників суспільно-правових відносин, для яких він однаково цінний. Як правило, публічний інтерес визнається державою та закріплюється в нормах публічного права, насамперед у положеннях Конституції України. Публічна адміністрація та публічне управління є єдиним суб'єктом, що має правові компетенції щодо забезпечення публічного інтересу, яке покладається на чинні адміністративно-правові акти [3, с. 18-19].

Об'єктивний характер публічного інтересу зумовлює необхідність створення у правовій системі відповідного синергетичного механізму, тобто механізму їх узгодження стосовно всіх учасників цього соціально-правового конфлікту.

Соціально-правовий механізм формування та реалізації державного управління публічним інтересом може бути представлений низкою взаємопов'язаних суспільно-правових актів, що опосередковані державою чи публічним управлінням як суб'єктом управління: «публічні потреби - публічні інтереси - публічна мета - рішення публічного управління чи адміністративно-правових установ у разі судового розгляду - дії на дотримання публічного інтересу або виправлення порушення публічного інтересу - результати реалізації публічного інтересу».

Розвиток вітчизняного законодавства, зокрема адміністративного, має спрямовуватися на врахування і забезпечення публічних інтересів, що в підсумку сприятиме поліпшенню правового регулювання відносин органів публічного управління і громадянина, частини громадянського суспільства чи суспільства загалом, а також протидіяти прийняттю непродуманих актів публічного управління, які не повністю задовольняють інтереси суспільства. У такому разі в контексті обговорення проблеми захисту публічного інтересу йдеться про охоронну функцію адміністративного права, оскільки сучасна теорія адміністративного акту забезпечує дотримання публічного інтересу через можливість судового оскарження будь-якого акту управління, якщо він перешкоджає реалізації прав і свобод фізичних чи юридичних осіб. Отже, адміністративне судочинство $€$ важливим адміністративно-правовим засобом забезпечення й захисту публічних інтересів, хоча нині це не встановлено нормативно, що може викликати суперечності і двозначність у практиці адміністративного судочинства.

3 огляду на можливість захисту публічного інтересу шляхом адміністративно-правового регулювання можна стверджувати, що правові акти публічного управління створюють підставу для формування системи адміністративної юстиції - важливого правового засобу усунення помилок у сфері адміністративного правоутворення через врахування численних публічних інтересів. Тут ідеться про позитивну управлінську діяльність, яка спрямована на вирішення публічного інтересу через здійснення публічного управління з дотримуванням прав та обов'язків усіх членів суспільства чи соціальних груп.

\section{Використана література:}

1. Адміністративне право України: навч. посіб. Т. 1:Загальне адміністративне право / В.В. Галунько, В.І. Курило, С.О. Короєд та ін.; за ред. В. В. Галунька. Київ: Ін-т публічного права, 2015. 180 с.

2. Бліхар М. Адміністративно-правові засоби захисту публічного інтересу. Юридичний вісник. 2021. № 3. C. 41-48.

3. Бліхар M.M. Публічне адміністрування як реалізація управлінських рішень; Public Administration and Management : modern scientific discussions : Collective monograph. Riga, Latvia : Baltija Publishing, 2020. P. 17-34.

4. Дячук Н.Д. Адміністративно-правовий механізм забезпечення прав суб'єктів приватного підприємництва в Україні. Науковий вісник Ужгородського наиіонального університету. Сер.: Право. 2016. Вип. 41 (1). С. 157-160.

5. Золотухіна Л.О., Легеза Ю.О. Гарантії захисту публічного інтересу. Юридичний бюлетень. 2020. Вип. 14. С. 39-48. URL: https://doi.org/10.32850/LB2414-4207.2020.14.05.

6. Калюжний P.A. Публічний інтерес у адміністративному праві. URL: https://er.nau.edu.ua/ bitstream/NAU/26547/1/.

7. Кармаліта В.М. Приватний і публічний інтерес у системі податкових правовідносин: монографія. Хмельницький: ФОП Мельник А. А., 2019. 328 с. 
8. Тернущак М.М. Адміністративний процес у публічному адмініструванні: автореф. дис. ... д-ра юрид. наук. Київ: Держ. наук.-дослід. ін-т т-ства внутр. справ України, 2020. 35 с.

9. Чернадчук В.Д. Стан та перспективи розвитку бюджетних правовідносин в Україні: монографія. Суми: Ун-ка книга, 2008. 456 с.

10. Фінансове право : Велика українська юридична енциклопедія : у 20 т. Т. 6. Харків : Право, 2020. $616 \mathrm{c}$.

11. Шиленко М.В. Поняття адміністративно-правової охорони суб'єктів малого підприємництва. Форум права. 2013. № 1. С. 1188-1193. URL: http://nbuv.gov.ua/UJRN/FP_index.

\section{References:}

1. Administratyvne Pravo Ukrainy: navch. posibnyk (2015). [Administrative law of Ukraine: textbook]. T. 1. Zagalne Administratyvne Pravo / V.V. Galun `ko, V.I. Kurylo, S.O. Koroied ta in.; za red. V.V. Galun 'ka. Kyiv: Inst-t publichnogo prava. 180 p. [in Ukrainian].

2. Blikhar M. (2021). Administratyvno-pravovi zasoby zaxystu publichnogo interesu. [Administrative and legal means of protection of public interest]. Yurydychnyj visnyk. Vol. 3. P. 41-48. [in Ukrainian].

3. Blikhar M.M. (2020). Publichne administruvannia iak realizaciia upravlins'kyx rishen'. [Public administration as the implementation of management decisions]; Public Administration and Management : modern scientific discussions : Collective monograph. Riga, Latvia : Baltija Publishing. P. 17-34. [in Latvia].

4. Diachuk N.D. (2016). Administratyvno-pravovyj mexanizm zabezpechennia prav sub iektiv pryvatnogo pidpryiemnyctva $v$ Ukraini. [Administrative and legal mechanism for ensuring the rights of private entrepreneurs in Ukraine]. Naukovyj visnyk Uszgorodskogo nacionalnogo universytetu. Seriia: Pravo. Vol. 41 (1). P. 157-160. [in Ukrainian].

5. Zolotuxina L.O., Legeza Yu.O. (2020). Garantii zaxystu publichnogo interesu. [Guarantees of protection of public interest]. Yurydychnyi biuleten'. Vol. 14. P. 39-48. Retrieved from: https://doi.org/10.32850/LB2414-4207.2020.14.05. [in Ukrainian].

6. Kaliusznyj R.A. (2017). Publichnyj interes u administratyvnomu pravi. [Public interest in administrative law]. Retrieved from: https://er.nau.edu.ua/bitstream/NAU/26547/1/. [in Ukrainian].

7. Karmalita V.M. (2019). Pryvatnyj i publichnyj interes u systemi podatkovyx pravovidnosyn: monographiia. [Private and public interest in the system of tax relations: a monograph]. Xmelnyc kyj: FOP Mel'nyk. 328 p. [in Ukrainian].

8. Ternushak M.M. (2020). Administratyvnyj process u publichnomu administruvanni [Administrative process in public administration]: avtoref. dyss. ... d-ra yuryd. nauk. Kyiv: Dersz. nauk.-doslid. In-t min. vnutr. sprav Ukrainy. 35 p. [in Ukrainian].

9. Chernadchuk V.D. (2008). Stan ta perspektyvy biudszetnyx pravovidnosyn v Ukraini: monographiia [Status and prospects of development of budgetary legal relations in Ukraine: monograph]. Sumy: Universytets`ka knyga. 456 p. [in Ukrainian].

10. Finansove Pravo : Velyka ukrains`ka yurydychna encyklopediia : u 20 t. (2020). [Financial law: The Great Ukrainian Legal Encyclopedia: in 20 vols]. Vol. 6. Kharkiv: Law. 616 p.

11. Shylenko M.V. (2013). Poniattia administratyvno-pravovoi ohorony sub iektiv malogo pidpryiemnyctva. [The concept of administrative and legal protection of small businesses]. Forum prava. Vol. 1. P. 1188-1193. Retrieved from: http://nbuv.gov.ua/UJRN/FP_index. [in Ukrainian].

\section{Blikhar M. M. Public interest in administrative law}

The article is devoted to the study of the features of public interest in administrative law. It is observed that the administrative law provides a real legal opportunity to appeal in court any act of management, if it violates or may violate the rights and freedoms of individuals or legal entities. In view of this, in the context of discussing the problem of public interests in administrative law, it is necessary to emphasize such administrative-procedural function of legal acts of public administration as appeals against illegal actions and decisions of state and local administration that do not meet the public interest. In this case, we can distinguish the law enforcement function of administrative law. After all, the interests of the social community are defined by the state as public interests; the law is designed to ensure their implementation and to promote the development of the social community through this public interest. It is proved that the importance of ensuring not only public interests but also private ones through legal mechanisms should not be ruled out, although many researchers of the theory of administrative law emphasize the vocation of administrative law to form, express, protect and ensure public interests. It is substantiated that 
the expediency and validity of administrative legal regulation depends on the chosen means of protection of public interest and its quality, which in turn affects the usefulness and importance of administrative and administrative-procedural acts in the process of ensuring public interests of conflicting parties. And the implementation of these powers in the administrative act is a specific sequence of actions defined by the procedure of control administrative proceedings.

Key words: public interest, legal mechanisms, administrative-legal regulation, administrative and legal protection, public administration, social and legal relations, law, legal relations, administrative law. 
УДК 342

DOI https://doi.org/10.31392/NPU-nc.series18.2021.36.03

Буковинська Н. А.

\title{
НАПРЯМИ УДОСКОНАЛЕННЯ ОРГАНІЗАЦИЙНОГО ТА ПРАВОВОГО ЗАБЕЗПЕЧЕННЯ ГЕНДЕРНОЇ ПОЛІТИКИ В УКРАЇНІ
}

\begin{abstract}
Ратифікація Угоди про асоиіачію між Україною та ЄС стала своєрідним поштовхом у розвитку політики рівних можливостей для чоловіків $і$ жінок у нашій державі. Перед Україною постали амбітні завдання з поліпшення якості людського капіталу, утвердження соціальної рівності, подолання дискримінащії тощо. Саме тому протягом останнього десятиліття в украӥнському суспільстві відбуваються істотні зміни з переосмислення та легітимації гендерних відносин, а також запроваджується інституиійний механізм їх регулювання. Українське суспільство залишається значною мірою патріархальним у поглядах на участь жінок $i$ чоловіків у політиці, публічній та приватній сферах життя суспільства, на ринку прачі, де часто спостерігаються гендерний дисбаланс і дискримінація за ознакою статі. У статті набули подальшого розвитку дослідження концептуальних засад гендерної політики в Україні й теоретичних підходів до ї̈ трактування. Наголошено на недосконалості иілісного механізму забезпечення гендерної рівності в Украӥні, спричиненій неповним залученням інституцій, які регулюють гендерні відносини, поодинокістю інституційних інновацій та браком усталених інституційних зв'язків між основними інституиіями, залученими до процесу регулювання гендерних відносин, щзо дало змогу обтрунтувати доцільність формування в нашій державі інституційних механізмів реалізації гендерної рівності за європейським зразком. Отримані висновки можуть бути використані у роботі держсавних органів і недержсавних організачій, діяльність яких пов 'язана з формуванням і реалізацією політики рівності в Україні, зокрема, для оцінювання чинних і розроблення нових державних програм із гендерної рівності; для удосконалення, розроблення й запровадження нових інституційних механізмів із забезпечення гендерної рівності; для поліпшення законодавства, яке стосується аспектів рівноправ'я; для розроблення інформаційних кампаній і програм сприяння гендерній толерантності в украӥнському суспільстві тощзо.
\end{abstract}

Ключові слова: гендер, гендерна рівність, гендерна політика, правові засади, подвійний підхід інституційний механізм, регулювання гендерних відносин.

Постановка проблеми у загальному вигляді та її зв'язок із важливими науковими чи практичними завданнями. Стан дотримання прав та свобод людини і громадянина у державі $є$ певним лакмусом рівня демократичного розвитку. Надзвичайно важливою $є$ можливість доступу до таких прав без будь-якої дискримінації для кожної особи. Ефективна правова політика держави сприяє захисту прав та свобод людини і громадянина, в тому числі і свободи від дискримінації. Дотримання прав людини є правовим ідеалом, на досягнення якого спрямований розвиток законодавства, а методами забезпечення є загальні принципи права.

Сучасний етап розвитку нашої державності гостро поставив питання забезпечення політики рівності в суспільних відносинах. Сьогодні ми маємо ситуацію, коли в Україні посилюється диференціація суспільства, одним із проявів якої є нерівність між статями, що особливо проявляється в нерівних можливостях жінок і чоловіків у сфері реалізації своїх прав. Специфіка гендерних проблем в Україні виявляється в тому, що на фоні доволі повної правової регламентації гендерної рівності, на практиці жінкам, а інколи і чоловікам, доволі складно нею скористатися. Все це актуалізує питання новітніх досліджень гендерних проблем з метою забезпечення рівності та справедливості у правових відносинах.

Демократичні принципи є основним орієнтиром у розбудові зовнішньої та внутрішньої політики України. Перед Україною постають амбітні завдання з поліпшення якості людського капіталу, утвердження соціальної справедливості і рівності усіх верств населення, подолання дискримінації тощо. Саме тому протягом останнього десятиліття в українському суспільстві відбуваються переосмислення та легітимація гендерних відносин, запроваджується інституційний механізм їх регулювання. 
Аналіз останніх досліджень і публікацій. Окремі аспекти забезпечення принципу рівності прав і свобод особистості розглядалися у працях К.Б. Айріян, О.В. Журби, О.Е. Лукашевої, Л.В. Мединської, В.М. Панькевича, О.М. Руднєва, І.С. Семенової, О.В. Ткалі, С.В. Ткаченка, К.І. Чижмарь, Н.Г. Шукліної, Г.В. Янковської та ін. Безпосередньо питанням гендерної рівності були присвячені дослідження Ц.Б. Жамсуєва, В.Ю. Зубакіна, Г.М. Комкової, В.С. Крилова, І.К. Полховської, В.Г. Федорової, К.О. Чернова та ін

Мета статті. Метою статті $є$ цілісне й грунтовне вивчення концептуальних засад гендерної політики в Україні та вироблення на цій основі напрямів удосконалення ії організаційного та правового забезпечення.

Виклад основного матеріалу дослідження. Упродовж останніх тридцяти років в утвердженні принципу рівних прав і можливостей для жінок і чоловіків у світі досягнуто значного прогресу. Принцип гендерної рівності дедалі частіше стає справжньою політичною силою впливу на забезпечення сталого розвитку, рівності та миру. У процесі еволюції на глобальному рівні виникають нові політичні ініціативи із забезпечення комплексного гендерного підходу шляхом розвитку інституційних механізмів, удосконалення та поповнення нормативно-правової бази і надання експертно-технічної допомоги. Як наслідок, на початку XX ст. 3'являється новий напрям - гендерна політика.

В основу концепції гендерної рівності покладено принцип недискримінації, «позитивних дій», забезпечення рівних прав і можливостей для жінок і чоловіків, що слугує наскрізним індикатором ефективності будь-якої політичної сфери демократичного суспільства. Саме тому наприкінці XX ст. з'являється розуміння критичної необхідності зміцнення механізмів імплементації та провадження гендерної політики.

Варто зазначити, що демократичне суспільство - це передусім суспільство з рівними можливостями для самовизначення та самореалізації всіх його членів, як чоловіків, так і жінок [1, с. 44].

Питання гендерної рівності поступово набуло визнання як невід'ємний елемент соціального ладу і стало складовою частиною усіх суспільних інститутів, закріпившись на пріоритетному місці в економіці, на ринку праці, в освіті, науці, політичних інституціях, ЗМІ тощо. На рівні найвищих органів державної влади в Україні проголошено прихильність до цінностей демократії та необхідності забезпечення гендерної рівності. На практиці це втілюється в окремих інституційних інноваціях, зокрема у Конституції України [2], Угоді про асоціацію між Україною та ЄС [3], Законі України «Про забезпечення рівних прав та можливостей жінок і чоловіків» [4], Державній соціальній програмі «Забезпечення рівних прав та можливостей жінок і чоловіків на період до 2021 року» [5] тощо. До регулювання гендерних відносин так чи інакше долучаються усі державні інститути, оскільки гендерна приналежність індивіда усвідомлюється і враховується під час будь-якої людської взаємодії і, відповідно, вбудовується в чинні державі організації та інституційний порядок.

Угода про асоціацію між Україною та СС охоплює зобов’язання щодо широкого кола питань політичної, соціальної, економічної, правової й інших сфер функціонування держави, серед яких дотримання гендерної рівності є наскрізним пріоритетом. Угода про асоціацію також визначає стратегічні орієнтири соціально-економічних реформ в Україні й розвитку національного законодавства. Перед Україною, відповідно до положень цього документа, постали амбітні завдання щодо поліпшення якості людського капіталу та утвердження соціальної справедливості. Це означає забезпечення гендерної рівності та рівних можливостей для представників обох статей у сферах зайнятості, освіти та навчання, економічної і громадської діяльності та у процесі ухвалення рішень. Сторони Зобов'язання з протидії дискримінації та забезпечення рівних можливостей визначені у спеціальній главі 21 Угоди про асоціацію - «Співробітництво у галузі зайнятості, соціальної політики та рівних можливостей» розділу $\mathrm{V}$ «Економічне та галузеве співробітництво». [3].

До ключових Директив РСС у групі «Антидискрімінація та гендерна рівність» глави 21 розділу V віднесено такі: про реалізацію принципу рівного ставлення до чоловіків і жінок щодо доступу та надання товарів і послуг; про реалізацію принципу рівного ставлення до осіб неза- 
лежно від расової або етнічної належності; про запровадження загальних правил рівного ставлення у сфері зайнятості та професійної діяльності; про рамкову угоду щодо батьківської/ декретної відпустки, укладеної ЮНІСЕФ, Європейським центром роботодавців та підприємств, СЕЕР і Європейською конфедерацією профспілок; про вжиття заходів із поліпшення безпечних і здорових умов праці вагітних працівниць, працівниць, які нещодавно народили; про поступову реалізацію принципу рівного ставлення до чоловіків і жінок із питань соціального забезпечення.

Основним меседжем перелічених директив є те, що будь-яка пряма або опосередкована дискримінація, заснована на гендерній, расовій або етнічній приналежності у сферах, які охоплюються цими документами, повинна бути заборонена на всій території ЄС. Заборона дискримінації повинна стосуватися і громадян третіх країн. У директивах також йдеться про те, що під час виконання принципу рівноправного поводження $Є C$, відповідно до ст. 3(2) Договору ЄС, повинен прагнути до усунення нерівноправності та сприяти поширенню ідеї рівноправності між чоловіками і жінками у всіх сферах суспільного життя, тим більше що жінки часто стають жертвами множинної дискримінації [6].

3 метою виконання зобов'язань захисту від дискримінації за ознакою статі, зокрема положень Директив № 2000/43/СС та № 2000/78/ЄС, на розгляді у Верховній Раді 155 України перебуває проєкт Закону України «Про внесення змін до деяких законодавчих актів України (щодо гармонізації законодавства у сфері запобігання та протидії дискримінації із правом Свропейського Союзу)» (реєстр. № 3501) [7], очікуючи на друге читання. 3 метою гармонізації з правом ЄС у сфері запобігання та протидії дискримінації внесено зміни до Кодексу законів про працю України, спрямовані на приведення законодавства України у відповідність до положень Директиви Ради № 2000/78/ЄС, що окреслює загальні рамки рівноправного поводження у сфері зайнятості і професійної діяльності. Завдяки таким позитивним змінам відкрито доступ жінкам до раніше заборонених професій [8].

Затверджену у квітні 2018 р. Державну соціальну програму забезпечення рівних прав та можливостей жінок і чоловіків на період до 2021 р. погоджено з РЄ і спрямовано на імплементацію положень Директив Ради 2004/113/СС та 79/7/ СЕС. 3 метою імплементації положень Директиви Ради 2010/18/ЄС розроблено проєкт Закону «Про внесення змін до деяких законодавчих актів України (щодо надання додаткових гарантій, пов'язаних із поєднанням сімейних і трудових обов'язків)», що передбачає створення рівних умов і можливостей для реалізації батьками своїх обов'язків щодо виховання й догляду за дітьми, підтримки материнства й батьківства [9]. Проведено значну роботу з практичного впровадження принципу гендерної рівності в усі сфери життя суспільства. Офіційно в Україні запроваджено святкування Дня батька - у третю неділя червня.

Відповідно до Звіту про виконання Угоди про асоціацію з СС, у 2017 р. скасовано майже всі обмеження (крім шахтних робіт) для жінок стосовно зайняття професіями (видами робіт), що відкриває жінкам доступ до цілих галузей. У новому Законі України «Про освіту» передбачена норма про обов'язковість здобуття учнями гендерної компетентності - здатності усвідомлювати рівні права й можливості. Недискримінація, рівність, забезпечення прав людини починаються з освіти й мають бути сформовані під час здобуття учнями загальної середньої освіти [10].

За відносно короткий проміжок часу Україна домоглася чималих успіхів у справі побудови справедливого та демократичного суспільства, де кожен зможе реалізувати власний потенціал, права кожного можуть бути захищені, а інтереси - враховані, незалежно від біологічної статі. Перелічені здобутки сприяють зростанню обізнаності населення про права кожного громадянина, поширенню інформації про випадки домашнього насильства (що більше не тема для табу), адже на державному рівні впроваджено механізми реагування та запобігання таким випадкам. Жінки почали опановувати нові, раніше не доступні для них професії. Підготовлено основу для більш ефективного планування, розроблення політики з урахуванням потреб різних груп населення, в тому числі жінок, які стикаються із множинною дискримінацією, на регіональному та центральному рівнях. Зростає усвідомлення, що рівність - це засадничий 
принцип існування сучасного демократичного суспільства, а також потужний поштовх для економічного розвитку.

Водночас, відповідно до Угоди про асоціацію з СС, перед Україною постали нові виклики у сфері гендерної політики: позитивний розвиток законодавства, спрямованого на ліквідацію дискримінації за ознакою статі та утвердження принципу рівного ставлення; повна заборона безпосередньої (прямої) та опосередкованої (непрямої) дискримінації за ознакою статі; заборона віктимізації жертв насильства за ознакою статі, переслідувань і сексуальних домагань як дискримінаційних дій; запровадження особливих/спеціальних заходів (позитивних дій), які сприяли б фактичному досягненню рівності між жінками та чоловіками на практиці та були би спрямовані на заборону прямої й непрямої дискримінації; ухвалення спеціальних законодавчих актів із питань гендерної рівності.

Крім підписаної Угоди про асоціацію між Україною та СС, не менш вагомими чинниками провадження гендерної політики в нашій державі є економічний та політичний. Адже рівні економічної активності та зайнятості серед жінок завжди були меншими, а рівень безробіття вищим, ніж серед чоловіків, тоді як заробітна плата жінок переважно не сягає й 80\% заробітної плати чоловіків [11, с. 174]. Поступове збільшення представництва жінок у Верховній Раді України, в органах місцевого самоврядування дає надію на зміцнення фундаментальних засад гендерної політики в державі. Європейська модель регулювання гендерної політики цілком придатна для застосування в Україні, оскільки у нас, як і в країнах $€ C$, ключовими виконавцями у процесах регулювання й дослідження гендерних відносин виступають інституції політики і держави.

Виконавцями другого плану у процесах регулювання і дослідження гендерних відносин в Україні є жіночі організації та інші громадські ініціативи (наприклад, «Чоловіки проти домашнього насилля»). Хоча в Україні є багато жіночих громадських організацій (близько тисячі зареєстрованих, за інформацією Державної служби статистики України), вони не мають такого впливу на формування інституційних засад регулювання гендерних відносин і політики забезпечення рівних прав. Лише 4\% усіх громадських організацій є масовими за складом та активними на національній арені, а це критично низький показник [12, с. 11].

Жіночі організації в Україні ще не налагодили належної взаємодії, тому розглядати жіночий рух як впливову суспільну та політичну силу, подібну до Жіночого лобі у Свропі, недоцільно. На тлі великої кількості організацій вирізняються кілька найбільш активних, що взаємодіють між собою, спільно провадять невеликі локальні дослідження і різноманітні тренінги та конференції. Більшість жіночих організацій (за винятком наукових чи освітніх гендерних центрів), спрямовують свої зусилля на вирішення соціальних проблем, які в Україні традиційно вважаються виключно жіночими (охорона материнства і дитинства, допомога дітям-інвалідам, малозабезпеченим, самотнім матерям, жінкам, які наражаються на дискримінацію, жінкам, які живуть у важких життєвих обставинах, тощо).

Дослідники гендерних відносин в Україні, зокрема, Н. Лавріненко, виокремлюють низку перешкод, які заважають розвиткові жіночого руху [12, с. 12]: патріархальні стереотипи українського суспільства («ренесанс патріархату», що особливо зміцнив свої позиції в пострадянський період); нерозвинена самосвідомість і слабка зорганізованість жінок; відмежування приватного життя в окрему сферу, що часто табуюється (домашнє насильство, сексуальне насильство тощо).

У сфері забезпечення гендерної рівності жінок і чоловіків сьогодні існує низка проблем, що потребують від України нагальних дій. Серед них - боротьба зі стереотипи масової свідомості, які досі розглядають жінку значно слабшу за чоловіка, а іiі роль у суспільному, політичному та економічному житті - як другорядну. Важливим завданням є підвищення рівня обізнаності державних службовців, представників недержавних організацій, наукових та освітніх установ, журналістів стосовно політики гендерної рівності в Україні. Виконати його можливо шляхом проведення відповідних тематичних заходів - семінарів, конференцій, публічних лекцій, соціальних рекламних кампаній тощо, а також спеціальних тренінгів 3 гендерної проблематики із залученням експертів з гендерних питань. Серед інших проблем українські вчені виокремлю- 
ють кризову економічну ситуацію (зокрема безробіття, яке штовхає жінок на заробітчанство, що часто призводить до торгівлі жінками та подальшої їх сексуальної експлуатації) й домінування на ринку праці попиту на працівників-чоловіків. Вимоги гендерного балансу необхідно враховувати і під час імплементації в Україні національної та регіональних політик, а також програм соціально-економічного й культурного розвитку.

Окрім того, наразі існує низка проблем і перешкод, що заважають гендерній політиці утвердитися. У тому числі недостатньо ефективним є національний механізм із забезпечення гендерного рівноправ’я. Свідченням цього є низка фактів.

1. Не виконуються задекларовані нашою країною зобов'язання. Наявне протиріччя між процесам в соціальних відносинах і задекларованою державною гендерною політикою. Виконання міжнародних зобов'язань стосовно гендерної рівноправності фактично не відбувається. Щоб утвердити в соціумі гендерну рівність, урядом було взято на себе низку зобов'язань: вдосконалення інституціонального механізму забезпечення рівності в правах і можливостях між жінками і чоловіками, утворення Національного гендерного ресурсного центру і розширення мережі гендерних ресурсних центрів по країні; забезпечення включення гендерного складника у Національну стратегію розвитку, державну, регіональні та галузеві програми соціальноекономічної розбудови тощо. Проте проблематика гендерного рівноправ'я не становить пріоритет для Кабміну.

2. Слабкий рівень системи застосування права. Рівність із правового погляду практично не забезпечується. Різниця між тим, як на папері і фактично просувається гендерна рівність в нашій країні, зумовлена тим, що правовій системі забезпечення гендерної рівності бракує економічних підстав, а контроль і моніторинг дотримання законодавчих норм щодо гендерного рівноправ'я здійснюється через недосконалі механізми. Недостатня відповідальність за те, що не виконуються нормативні акти. Україні властива слабка система правозастосування (законодавство виконується необов'язково або селективно). Попри те, що існує доволі жорстке законодавство по захисту громадянських прав, контролюючі механізми щодо його реалізації доволі слабкі.

3. Слабко втілюються гендерні підходи в межах основних державних стратегій, слабкий рівень впливу на гендерні зрушення в соціумі. Між пріоритетом гендерної паритетності та іншою стратегічною документацією немає зв'язку.

4. Слабкий рівень кадрового забезпечення. Внаслідок кадрових змін, які сталися після зміни уряду, до влади прийшло багато осіб, які зовсім не обізнані з гендерною проблематикою. Державні службовці на кожному рівні слабко розуміють необхідність реалізації гендерних підходів, нерозвинена гендерна свідомість. Практично це передбачає, що інститути не здатні здійснювати ефективний вплив на гармонізацію зовнішньої допомоги, покликаної просувати гендерну рівність.

Проблемним аспектом вважаємо і відсутність позитивної судової практики з питань забезпечення гендерної рівності. Аналіз Єдиного державного реєстру судових рішень дозволяє зробити висновок про існування незначної кількості випадків констатації судами дискримінації особи за ознакою статі. Здебільшого судова практика представлена рішеннями, у яких органами правосуддя не вбачається порушень та обмежень по відношенню до особи за вказаною ознакою. Так, Львівський окружний адміністративний суд у відповідній постанові відмовив у задоволенні позову особі-військовослужбовцю щодо визнання протиправними дій командира військової частини по відмові у наданні соціальної відпустки для догляду за дитиною до досягнення нею 3-річного віку [13]. Причиною прийняття такого рішення є відсутність правових підстав для надання особі зазначеного виду відпустки, оскільки останній не є батьком, який виховує дитину без матері. При цьому у ході розгляду справи судом не було виявлено застосування керівництвом військової частини дискримінації до особивійськовослужбовця за ознакою статі, зважаючи на обгрунтоване відступлення від зобов'язань за Європейською конвенцією з прав людини у зв'язку із існуванням особливого періоду в державі (мобілізації), легітимною метою якого є захист національної та громадської безпеки.

Висновки. Регулювання гендерних відносин в Україні характеризуються, по-перше, неповним залученням інституцій, які регулюють гендерні відносини в суспільстві (зокрема, інсти- 
туції політики та економіки отримують значно більше уваги від органів державної влади, ніж інститут сім'ї та культура); по-друге, впровадженням поодиноких інституційних інновацій, діяльність яких не завжди грунтується на цінностях гендерної рівності, проголошеної міжнародною спільнотою; по-третє, неналагодженістю усталених інституційних зв'язків (правових, соціальних, економічних тощо) між основними інститутами, залученими до регулювання гендерних відносин. Завдання вдосконалення гендерної політики залишається актуальним для України, незважаючи на ухвалення за останні роки багатьох національних законів і нормативноправових актів у цій сфері. Національний механізм забезпечення гендерної рівності в Україні $\epsilon$ політично слабким та малоефективним. Норми законів, які гарантують рівність і недискримінацію, є декларативними, органи влади не мають реальних важелів впливу на порушників. Реальні процеси у сфері соціальних відносин суперечать задекларованій державній гендерній політиці, міжнародні зобов'язання з гендерної рівності де-факто не виконуються. Немає єдиної концепції (стратегії) гендерної політики, у програмах уряду переважає соціальна риторика, наявна державна програма не містить звітних механізмів та системи моніторингу виконання запланованих заходів. Вважаємо за необхідне переглянути державну ідеологічну доктрину гендерної рівності та розробити і прийняти новий закон «Про гендерну рівність в Україні».

\section{Виктористана література:}

1. Агеєва В., Марценюк Т. Інша оптика: гендерні виклики сучасності. Київ: Смолоскип, 2019. $256 \mathrm{c}$.

2. Конституція України від 28 червня 1996 року. Верховна Рада Украйни: вебсайт. URL : https://zakon.rada.gov.ua/laws/show/254\%D0\%BA/96- \%D0\%B2\%D1\%80

3. Угода про асоціацію між Україною, з однієї сторони, та Свропейським Союзом, Свропейським співтовариством з атомної енергії і їхніми державами-членами, з іншої сторони: вебсайт. URL: https://zakon.rada.gov.ua/laws/show/984_011

4. Про забезпечення рівних прав та можливостей жінок і чоловіків: Закон України від 8 верес. 2005 p. No 2866-IV. Верховна Рада України : вебсайт. URL: http://portal.rada.gov.ua

5. Про затвердження Державної соціальної програми забезпечення рівних прав та можливостей жінок і чоловіків на період до 2021 р.: Постанова Кабінету Міністрів України від 11 квітня 2018 p. No 273. Урядовий портал : вебсайт. URL: https://www.kmu.gov.ua/ua

6. Звіт Віце-прем'єр-міністра 3 питань європейської та євроатлантичної інтеграції України за час роботи в Уряді 2016 - 2019 pp. URL: https://helsinki.org.ua/wp-content/uploads/2019/02/Report-onGender-policy- for-2018_ukr.pdf

7. Про внесення змін до деяких законодавчих актів України (щодо гармонізації законодавства у сфері запобігання та протидії дискримінації із правом Європейського Союзу): Проект Закону 0931 від 29.08.2019. URL: http://w1.c1.rada.gov.ua/pls/zweb2/webproc4_1?pf3511=66561

8. Про внесення зміни до Кодексу законів про працю України щодо гармонізації законодавства у сфері запобігання та протидії дискримінації з правом Європейського Союзу: Закон України. URL: https://zakon.rada.gov.ua/laws/show/785-19

9. Про внесення змін до деяких законодавчих актів України (щодо надання додаткових гарантій, пов'язаних з поєднанням сімейних і трудових обов'язків: Проект Закону 9045 від 05.09.2018. URL: http://w1.c1.rada.gov.ua/pls/zweb2/webproc4_1?pf3511=64544

10. Звіт із впровадження політики гендерної рівності та недискримінації УГСПЛ у 2018 році. Загальнийопис, висновкитарекомендації.URL:https://helsinki.org.ua/wp-content/uploads/2019/02/ Report-on-Gender-policy- for-2018_ukr.pdf

11. Сгоров I., Красовська О. Основи гендерної політики : навч.-метод. посіб. Київ: ДП «Укртехінформ», 2013. $234 \mathrm{c.}$

12. Лавріненко Н. Жіночий рух у посткомуністичній Україні: досягнення і прорахунки. Політичний nортрет України : бюлетень дослідно- навчального центру «Демократичні ініціативи». 1995. No 13. C. 9-14.

13. Рішення Львівського окружного адміністративного суду від 16.03.2018p. URL: http://www.reyestr.court.gov.ua/Review/72949487 


\section{References:}

1. Aheieva V., Martseniuk (2019) T. Insha optyka: henderni vyklyky suchasnosti [Other optics: gender challenges of today]. Kyiv: Smoloskyp, $256 \mathrm{~s}$.

2. Verkhovna Rada of Ukraine (1996). Konstytutsiia Ukrainy [Constitution of Ukraine]. Vidomosti Verkhovnoi Rady Ukrainy, no. 30, art. 141. Retrieved from: https://zakon.rada.gov.ua/laws/ show $/ 254 \% \mathrm{D} 0 \% \mathrm{BA} / 96-\% \mathrm{D} 0 \% \mathrm{~B} 2 \% \mathrm{D} 1 \% 80$ [in Ukrainian]

3. Uhoda pro asotsiatsiiu mizh Ukrainoiu, z odniei storony, ta Yevropeyskym Soiuzom, Yevropeyskym spivtovarystvom $\mathrm{z}$ atomnoi enerhii i ikhnimy derzhavamy-chlenamy, z inshoi storony: vebsayt. URL: https://zakon.rada.gov.ua/laws/show/984_011

4. Verkhovna Rada of Ukraine (2005). Pro zabezpechennia rivnykh prav ta mozhlyvostey zhinok i cholovikiv [On ensuring equal rights and opportunities for women and men] Vidomosti Verkhovnoi Rady Ukrainy vid 08.09.2005 № 2866-IV. Retrieved from https://zakon.rada.gov.ua/laws/card/2866-15 [in Ukrainian]

5. Cabinet of Ministers of Ukraine (2018). Pro zatverdzhennia Derzhavnoi sotsialnoi prohramy zabezpechennia rivnykh prav ta mozhlyvostey zhinok i cholovikiv na period do $2021 \mathrm{r}$. [About the statement of the State social program of maintenance of equal rights and opportunities of women and men for the period till 2021]: Postanova Kabinetu Ministriv Ukrainy no. 273. Retrieved from: https://www.kmu.gov.ua/npas/pro-zatverdzhennya-derzhavnoyi-socialnoyi-programizabezpechennya-rivnih-prav-ta-mozhlivostej-zhinok-i-cholovikiv-na-period-do-2021-roku

6. Zvit Vitse-premier-ministra z pytan yevropeiskoiskoi ta yevroatlantychnoi intehratsii Ukrainy za chas roboty v Uriadi 2016 - 2019 rr. URL: https://helsinki.org.ua/wp-content/uploads/2019/02/Report-onGender-policy- for-2018_ukr.pdf

7. Verkhovna Rada of Ukraine (2019). Pro vnesennia zmin do deiakykh zakonodavchykh aktiv Ukrainy (shchodo harmonizatsii zakonodavstva u sferi zapobihannia ta protydii dyskryminatsii iz pravom Yevropeiskoho Soiuzu) [On Amendments to Certain Legislative Acts of Ukraine (Regarding Harmonization of Legislation in the Sphere of Prevention and Counteraction of Discrimination with the Law of the European Union]: Vidomosti Verkhovnoi Rady Ukrainy: Proekt Zakonu 0931.Retrieved from: http://w1.c1.rada.gov.ua/pls/zweb2/webproc4_1?pf3511=66561

8. Verkhovna Rada of Ukraine (2015). Pro vnesennia zminy do Kodeksu zakoniv pro pratsiu Ukrainy shchodo harmonizatsii zakonodavstva u sferi zapobihannia ta protydii dyskryminatsii z pravom Yevropeyskoho Soiuzu [On Amendments to the Labor Code of Ukraine on Harmonization of Legislation in the Sphere of Prevention and Counteraction of Discrimination with the Law of the European Union] Vidomosti Verkhovnoi Rady Ukrainy, no. 49-50, Retrieved from: https://zakon.rada.gov.ua/laws/show/785-19

9. Verkhovna Rada of Ukraine (2018). Pro vnesennia zmin do deiakykh zakonodavchykh aktiv Ukrainy (shchodo nadannia dodatkovykh harantii, poviazanykh $\mathrm{z}$ poiednanniam simeinykh i trudovykh oboviazkiv [On amendments to some legislative acts of Ukraine (concerning the provision of additional guarantees related to the combination of family and work responsibilities:]: Vidomosti Verkhovnoi Rady Ukrainy: Proekt Zakonu 9045 Retrieved from: http://w1.c1.rada.gov.ua/pls/zweb2/ webproc4_1?pf3511=64544

10. Zvit iz vprovadzhennia politykky hendernoi rivnosti ta nedyskryminatsii UHSPL u 2018 rotsi. Zahalnyy opys, vysnovky ta rekomendatsii [Report on the implementation of the policy of gender equality and non-discrimination of the Ukrainian Helsinki Human Rights Union in 2018. General description, conclusions and recommendations] Retrieved from: https://helsinki.org.ua/wp-content/ uploads/2019/02/Report-on-Gender-policy- for-2018_ukr.pdf

11. Iehorov I., Krasovska (2013) O. Osnovy hendernoi polityky: navch.-metod. posib. [Fundamentals of gender policy] Kyiv: DP «Ukrtekhinform», $234 \mathrm{~s}$.

12. Lavrinenko N. (1995) Zhinochyy rukh u postkomunistychniy Ukraini: dosiahnennia i prorakhunky [Women's movement in post-communist Ukraine: achievements and failures]. Politychnyy portret Ukrainy: biuleten doslidno- navchalnoho tsentru «Demokratychni initsiatyvy». No 13. S. 9-14.

13. Rishennia Lvivskoho okruzhnoho administratyvnoho sudu [Decision of the Lviv District Administrative Court] vid 16.03.2018r. Retrieved from: http://www.reyestr.court.gov.ua/Review/72949487 


\section{Bukovynska N. A. Directions of improvement of organizational and legal support of gender} policy in Ukraine

Ratification of the Association Agreement between Ukraine and the EU has become a kind of impetus for the development of equal opportunities policy for men and women in our country. Ukraine faces ambitious tasks to improve the quality of human capital, promote social justice and equality, overcome discrimination, and so on. That is why over the last decade in Ukrainian society there have been significant changes in rethinking and legitimizing gender relations, as well as introducing an institutional mechanism for their regulation. Ukrainian society remains largely patriarchal in its views on the participation of women and men in politics, public and private spheres of society, the labor market, where gender imbalances and gender discrimination are common. The article further develops the study of the conceptual foundations of gender policy in Ukraine and theoretical approaches to its interpretation. Emphasis was placed on the imperfection of the integrated mechanism for gender equality in Ukraine, caused by incomplete involvement of institutions regulating gender relations, loneliness of institutional innovations and lack of established institutional links between the main institutions involved in the process of regulating gender relations. state institutional mechanisms for the implementation of gender equality on the European model. The obtained conclusions can be used in the work of state bodies and non-governmental organizations whose activities are related to the formation and implementation of gender policy in Ukraine, in particular, to assess existing and develop new state programs on gender equality; to improve, develop and implement new institutional mechanisms to ensure gender equality; to improve gender-related legislation; to develop information campaigns and programs to promote gender tolerance in Ukrainian society, etc.

Key words: gender, gender equality, gender policy, legal framework, dual approach, institutional mechanism, regulation of gender relations. 


\author{
УДК 349.2 \\ DOI https://doi.org/10.31392/NPU-nc.series18.2021.36.04
}

Глущенко М. П.

\title{
РОЛЬ ПРОФСПІЛОК У ЗАХИСТІ ТРУДОВИХ ПРАВ В УМОВАХ РОЗВИТКУ ЦИФРОВОЇ ЕКОНОМІКИ
}

Стаття присвячена дослідженню питання щодо ролі $і$ значення професійних спілок для відстоювання $і$ захисту трудових прав $i$ законних інтересів працівників в умовах ијифровізації економіки та розвитку нестандартних форм зайнятості, зокрема роботи на онлайн-платформах. Наголошено, щзо в умовах сьогодення роль професійних спілок у захисті соиіально-трудових прав - комплексне питання, вирімення якого потребує системних підходів до різних напрямів діяльності профспілок. Враховуючи різноманітність форм реалізачії профспілками захисної функиії, вони не можуть залишатися незмінними у зв'язку з трансформаціями у сфері праці й зайнятості, зумовленими розвитком інформаційних технологій, зокрема поширенням нестандартних форм зайнятості.

Зазначено, щро більшість нестандартних та новітніх форм зайнятості зазвичай передбачають відсутність прямої залежності працівника від роботодавия. Найбільш складні форми зайнятості пов'язані з розвитком Інтернету та пристроїв мобільного зв'язку, в яких не завжди очевидно, чи існують трудові відносини, чи ні, і ще складніше визначити, чи повинні розповсюджуватися на осіб, залучених до таких форм зайнятості, гарантії захисту прав прачівників, щзо існують у стандартних трудових відносинах. Все ие зумовлює необхідність запровадження відповіднихмеханізмів, які б дозволяли розповсюдити колективно-договірне регулювання на працівників із нестандартною (нестійкою) зайнятістю, зокрема зайнятих на інтернет-платформах. Однією з гарантій реалізації таких прав може стати включення таких працівників до кола соціальних партнерів шляхом надання їм самостійного права на колективні переговори та/або представнищтво на ринку праці галузевими профспілками.

Ключові слова: професійні спілки, нестандартні форми зайнятості, інтернет-платформи, право на об'єднання, захист трудових прав.

Постановка проблеми. Актуальність захисту трудових прав найманих працівників зумовлена як динамічними змінами й новими викликами в соціально-економічній сфері нашої держави, так і перманентними спробами реформування трудового законодавства, адже розбудова та розвиток правової соціальної держави неможливі без удосконалення юридичних гарантій здійснення трудових прав працівників та форм їх захисту.

В умовах сьогодення роль професійних спілок у захисті соціально-трудових прав - комплексне питання, вирішення якого потребує системних підходів до різних напрямів діяльності профспілок, враховуючи різноманітність форм реалізації їхньої захисної функції, які не можуть залишатися незмінними у зв'язку з трансформаціями у сфері праці й зайнятості, зумовленими розвитком інформаційних технологій, зокрема поширенням нестандартних форм зайнятості.

Аналіз останніх досліджень. Правове регулювання діяльності професійних спілок у тому чи іншому аспекті було предметом дослідження багатьох науковців України з різних галузей права. Зокрема, Н.А. Циганчук вивчала професійні спілки як суб’єктів трудового права. Теоретичним проблемам участі профспілок у розбудові соціально-правової держави присвятила своє дисертаційне дослідження В.В. Соломінчук. Конституційно-правові засади організації та діяльності професійних спілок в Україні та країнах СС у докторській дисертації дослідив О.О. Піфко. До вивчення адміністративно-правового статусу профспілок в Україні зверталася у своїй роботі А.Ю. Шакірова. Однак, незважаючи на значний інтерес учених-правників, проблематика щодо ролі професійних спілок у захисті трудових прав і законних інтересів працівників не втрачає своєї актуальності з огляду на трансформаційні процеси соціально-економічної сфери, зумовлені інформатизацією та цифровізацією.

Мета статті полягає у з'ясуванні ролі профспілок у захисті трудових прав та інтересів працівників в умовах цифровізації економіки та розвитку нестандартних форм зайнятості, зокрема роботи на онлайн-платформах. 
Виклад основного матеріалу. Конституція України, гарантуючи громадянам право на об'єднання у статті 36, окремо виділяє право на участь у професійних спілках з метою захисту своїх трудових і соціально-економічних прав та інтересів [1].

Право на свободу об’єднання є одним з фундаментальних міжнародних прав працівників. Відповідно до преамбули Статуту Міжнародної організації праці (далі - МОП) визнання принципу свободи об'єднання є однією з умов поліпшення умов праці та встановлення миру [2]. Основним міжнародним актом, що гарантує право на свободу об'єднання, є Конвенція МОП № 87 від 09 липня 1948 року «Про свободу асоціації та захист права на організацію», ратифікована ще за часів УРСР, 06 липня 1956 року [3]. При цьому Комітет МОП зі свободи об'єднань відзначає, що той рівень захисту прав профспілок, який закріплений у Конвенції МОП № 87, $€$ мінімальним стандартом, а держави мають працювати над тим, аби встановлювати додаткові гарантії охорони та захисту прав профспілок, зважаючи на свої правові системи та розвиток трудових відносин [4].

У прийнятій у 1998 році Декларації МОП основних принципів та прав у світі праці принцип свободи асоціації та реальне визнання права на ведення колективних переговорів закріплено першим із чотирьох основних принципів, які є предметом фундаментальних конвенцій МОП [5].

Крім того, право створювати для здійснення і захисту своїх економічних та соціальних інтересів професійні спілки закріплено у ст. 8 Міжнародного пакту про економічні, соціальні і культурні права 1966 року [6], ст. 22 Міжнародного пакту про громадянські та політичні права 1966 року [7], ст. 5 Свропейської соціальної хартії (переглянутої) 1996 року [8], ст. 11 Конвенції про захист прав людини та основоположних свобод та право на свободу асоціації [9], а також дістало закріплення в Угоді про асоціацію між Україною, з однієї сторони, та Європейським Союзом, Свропейським співтовариством з атомної енергії і їхніми державами-членами, з іншої сторони (ч. 2 ст. 291) [10].

Слушною є думка В.В. Соломінчук, яка зазначає, що «необхідні межі втручання держави у діяльність профспілок мають бути зведеними до мінімуму та забезпечувати досягнення оптимального балансу інтересів держави і суспільства, створювати максимально сприятливі умови для реалізації громадянами права на об'єднання у профспілки та для одночасного захисту членів суспільства від можливих зловживань цим правом. Встановлення невиправданих обмежень у створенні та діяльності профспілок призводитиме до порушення фундаментального конституційного права громадян на свободу об'єднання» [11, с. 13].

На думку I.I. Яцкевича, з метою удосконалення правового регулювання повноважень профспілки щодо захисту трудових прав та інтересів працівників варто не лише зберегти чинні норми законодавства щодо повноважень профспілок у сфері захисту трудових прав та інтересів працівників, а й передбачити нові положення, спрямовані на підвищення спроможності професійних спілок на варті трудових прав та інтересів працівників. 3 урахуванням положень міжнародних актів загальний позитивний ефект на зміцнення позицій профспілок у справ захисту як індивідуальних, так і колективних трудових прав матиме приєднання України до Додаткового протоколу до Європейської соціальної хартії, який передбачає систему колективного оскарження (ETS № 158)115 [12, с. 112].

В умовах цифровізації економіки питання захисту трудових прав та інтересів працівників за допомогою профспілок постають особливо гостро з огляду на стрімкий перехід до надання послуг за допомогою різноманітних інтернет- або онлайн-платформ, які виступають посередником між користувачами послуг та їх надавачами. При цьому особи-надавачі таких послуг (кур'єри, водії таксі тощо) не визнаються працівниками, а отже, позбавлені можливості мати будь-які базові гарантії трудового права та є соціально незахищеними.

За даними МОП, понад 6 працівників із 10 та 4 підприємств із 5 у світі працюють у неформальній економіці. На відміну від старих прогнозів, неформальність із часом не зменшується і навіть зростає у багатьох країнах. Неформальна економіка, як правило, характеризується високим рівнем бідності та серйозним дефіцитом гідної праці [13].

Як зазначає Я.В. Сімутіна, сучасна трудова діяльність істотно відрізняється від тієї, яка була найбільш поширеною у період промислового суспільства, коли сформувалася більшість кла- 
сичних норм трудового права. 3 початку XXI століття у сучасному лексиконі міцно закріпилися поняття «гіг-економіка», «онлайн-платформи» тощо, а найбільш характерні ознаки трудових правовідносин у повному обсязі залишаються притаманними лише для обмеженого кола найманих працівників за трудовим договором [14, с. 144].

У дослідженні МОП 2016 року, присвяченому нестандартній зайнятості, ці форми праці розуміються досить широко. Фахівці МОП виділяють чотири нестандартні форми зайнятості: 1) тимчасову зайнятість (строкові трудові договори, включаючи виконання разових чи сезонних робіт); роботу на умовах неповного робочого часу (включає роботу за викликом та трудові договори з нульовим робочим часом); 3) трудові правовідносини більш ніж із двома сторонами (так звана позикова праця); 4) прихована зайнятість або залежна самозайнятість, за якої трудові відносини оформлюються як цивільно-правові) [15]. При цьому не всі форми нестандартної зайнятості слід відносити до нових форм праці, що виникли в результаті інформаційно-технологічної революції. Поза тим більшість із них належать саме до нестандартної зайнятості, частка якої зростає у зв'язку із появою нових форм залучення до праці.

Європейський фонд із покращення умов праці та життя (Сврофонд) у 2015 році опублікував дослідження, присвячене так званим новітнім формам зайнятості. До таких форм, зокрема, віднесені:

- «employee sharing» (з англ. «працівник на обмін» або «спільне використання працівника»), коли індивідуальний працівник спільно найнятий групою роботодавців для задоволення кадрових потреб різних компаній, внаслідок чого такий працівник працює по черзі на різних роботодавців;

- «job sharing» (з англ. «розподіл роботи»), коли роботодавець наймає двох або більше працівників для спільного виконання конкретної роботи, об'єднуючи два або більше неповних робочих місця на повний робочий день;

- «interim management» (з англ. «тимчасове управління»), коли висококваліфіковані спеціалісти тимчасово приймаються на роботу для реалізації конкретного проєкту або вирішення конкретної проблеми, тим самим інтегруючи зовнішні управлінські можливості в організацію роботи;

- «casual work» (з англ. «разова або випадкова робота»), коли роботодавець не зобов'язаний регулярно надавати роботу працівнику, але може викликати його у випадку потреби. Сврофонд виокремив дві схеми разової зайнятості: нерегулярна робота (intermittent work) та робота за запитом (on-call work) або контракти з нульовим робочим часом (zero-hours contracts);

- «ICT-based mobile work» (з англ. «мобільна робота на базі IКТ»), де працівники можуть у будь-який час виконувати свою роботу з будь-якого місця, застосовуючи сучасні інформаційнокомп'ютерні технології. У законодавстві України ця нестандартна форма зайнятості відома як дистанційна праця, що врешті отримала своє законодавче закріплення під тиском нових викликів, пов'язаних із пандемією COVID19;

- «crowd employment» (з англ. дослівно «зайнятість у натовпі»), коли роботодавці та працівники взаємодіють на певній онлайн-платформі, і завдання розподіляються між працівниками у «віртуальній хмарі» [16].

Більшість нестандартних та новітніх форм зайнятості зазвичай передбачають відсутність прямої залежності працівника від роботодавця. Працівник може вибирати, як і коли він виконує свої завдання. Найбільш складні форми зайнятості пов'язані з розвитком Інтернету та пристроїв мобільного зв'язку, в яких не завжди очевидно, чи існують трудові відносини, чи ні, і ще складніше визначити, чи повинні розповсюджуватися на осіб, залучених до таких форм зайнятості, гарантії захисту прав працівників, що існують у стандартних трудових відносинах $[17$, c. 426$]$.

Все це зумовлює необхідність запровадження відповідних механізмів захисту соціальнотрудових прав працівників цього сегменту ринку праці.

У таких умовах європейські дослідники наголошують на надзвичайній важливості солідарності та об'єднання поза звичними межами робочих місць на підприємствах. Враховуючи це, основним завданням профспілок у державі з цифровою економікою вчені 
вважають організаційне об'єднання працівників з нестандартними формами зайнятості [18, c. $130-168]$.

Однією з гарантій реалізації таких прав може стати включення таких працівників до кола соціальних партнерів шляхом надання їм самостійного права на колективні переговори та/або представництво на ринку праці галузевими профспілками.

Зокрема, у державах, де переважають колективні переговори на галузевому рівні, це може бути шляхом приєднання цифрових платформ до існуючих асоціацій роботодавців або створення ними власних асоціацій та взаємодії з професійними спілками в рамках правил, встановлених національним законодавством. Наприклад, у Німеччині в параграфі 12А Закону про тарифний договір закріплено правило щодо застосування цього акта до осіб, схожих на працівників, тобто таких, які є економічно залежними та потребують соціального захисту в тій самій мірі, в якій і працівники, якщо такі особи працюють на підставі підрядних договорів в інтересах інших осіб або надають послуги переважно особисто (без залучення працівників) для однієї особи та якщо вони мають право на отримання більше половини винагороди, на яку вони б мали право за умов повної зайнятості при дотриманні передбачених законом вимог. Крім того, цей закон поширює на осіб, схожих на найманих працівників, право на страйк [19].

В останні роки в українських ЗМІ почастішали повідомлення про протестні акції кур'єрів Glovo, Bolt Food тощо, на яких все активніше лунають заклики до об'єднання та створення профспілки для відстоювання своїх трудових і соціальних прав. Разом із тим невизначений правовий статус таких осіб, а також норми чинного українського законодавства не дозволяють їм виступати в якості легітимних представників працівників, зайнятих на інтернет-платформах, у соціальному діалозі з бізнесом та державою.

Конституція України гарантує усім громадянам право на участь у професійних спілках. Водночас Закон України «Про професійні спілки, їх права та гарантії їх діяльності» (далі Закон про профспілки) визначає, що членами профспілок можуть бути особи, які працюють на підприємстві, в установі або організації незалежно від форм власності і видів господарювання, у фізичної особи, яка використовує найману працю, особи, які забезпечують себе роботою самостійно, особи, які навчаються в закладі освіти. Незважаючи на те, що Закон про профспілки не містить обмежень щодо того, що трудова діяльність має бути лише колективною, нині профспілки й досі традиційно вважаються представницькими організаціями лише працівників, які перебувають у трудових відносинах з підприємством, установою, організацією. Адже згадка у наведеній вище нормі про осіб, які забезпечують себе роботою самостійно, залишає певний простір для реалізації права на об'єднання «некласичних» працівників, проте відсутність механізмів, які б дозволяли розповсюдити колективно-договірне регулювання на працівників із нестандартною (нестійкою) зайнятістю, зокрема зайнятих на інтернет-платформах, поки що унеможливлює ефективний захист трудових прав таких осіб у нашій державі.

У зв'язку з цим захисні дії з боку професійних спілок щодо об'єднання зайнятих на інтернет-платформах реалізуються переважно в площині колективних протестних акцій, що організовуються за допомогою соціальних мереж та месенджерів, через які профспілки планують та координують свої акції, що за своїм змістом нагадують страйки, проте юридично такими не $\epsilon$, виходячи $з$ поняття та порядку оголошення страйку, закріплених нині в нормах Закону України «Про порядок вирішення колективних трудових спорів (конфліктів).

Водночас, як свідчить практика зарубіжних країн, профспілки працівників з нестандартними формами зайнятості, в тому числі й тих, що залучені до праці через інтернет-платформи, здатні зробити свій відчутний внесок у правову регламентацію діяльності, що нині не вкладається в рамки класичних категорій трудового права, особливо в тих випадках, коли на певні групи зайнятих осіб не поширюються норми законодавства про працю.

У низці європейських країн вже $є$ позитивний досвід укладення на загальнодержавному рівні колективних угод, покликаних покращити умови праці кур'єрів. Зокрема, на початку 2021 року профспілка 3F Transport та Торгова палата Данії уклали загальнонаціональний колективний договір, за яким працівникам служб доставки гарантуються основні трудові права, включаючи забезпечення відпустки по догляду за дитиною, забезпечення пенсійних відрахувань, мож- 
ливість вести переговори щодо розміру зарплати, право на оплачувану відпустку, оплачувані лікарняні, при цьому вартість послуг з доставки не змінюється. Компанія Just-Eat, яка використовує працю близько 600 кур'єрів 3 доставки їжі, першою долучилась до цього договору, забезпечивши їх базовими трудовими правами [20].

Як зазначають експерти в найбільшому об'єднанні профспілок США, нині є три напрями діяльності профспілок у гіг-економіці. Перший полягає у виробленні юридичної стратегії, спрямованої на боротьбу з позовами про оскарження статусу незалежних підрядників працівників гіг-економіки. Другий - розвиток асоціацій та альянсів, які надають різного роду послуги для працівників гіг-економіки та адвокатують за них. I третій - просування реформи законодавства 3 метою сприяння реалізації права на асоціацію та ведення колективних переговорів для працівників платформ [21].

Висновки. Підсумовуючи, слід зазначити, що одним із найбільш гострих викликів цифровізації економіки в Україні стає вироблення адекватного механізму реалізації працівниками 3 нестійкою, нестандартною зайнятістю одного з фундаментальних прав - права на об'єднання для колективного захисту своїх соціально-економічних інтересів та застосування законних представницьких повноважень профспілок, у тому числі й у сфері нестандартної зайнятості.

У світлі наведеного не можемо не піддати критиці спроби нинішнього Уряду України знівелювати захисну функцію профспілок. Так, у розробленому Кабінетом Міністрів України проєкті Закону «Про внесення змін до деяких законодавчих актів щодо дерегуляції трудових відносин», реєстр. № 5388 від 16.04.2021, який 02 червня 2021 Верховна Рада України прийняла за основу у першому читанні, фактично нівелюються існуючі правові важелі профспілок захищати трудові і соціально-економічні права навіть тих найманих працівників, які працюють на підставі трудових договорів. При цьому загальною тенденцією у розвинених країнах $\epsilon$ посилення ролі професійних спілок у колективних переговорах з метою наділення відповідними соціальними гарантіями не тільки працівників, які працюють за трудовими договорами, а й тих, зайнятість яких здійснюється у нестандартних формах.

Нині у світі не вироблено універсальної моделі розвитку колективного представництва працівників із нестандартною зайнятістю, оскільки реалізація права на об’єднання залежить від багатьох факторів, починаючи від специфіки правового регулювання праці в конкретній державі, закінчуючи особливостями діяльності цифрових платформ. Поза тим очевидною є необхідність об'єднання зусиль та взаємодії професійних спілок, роботодавців та держави для адекватної відповіді на вже наявні та майбутні виклики у соціально-трудовій сфері.

\section{Використана література:}

1. Конституція України. Відомості Верховної Ради України. 1996. № 30. Ст. 141. URL: https://zakon.rada.gov.ua/laws/show/254\%D0\%BA/96-\%D0\%B2\%D1\%80\#Text

2. Статут Міжнародної Організації Праці від 28.06.1919 p. URL: https://zakon.rada.gov.ua/laws/ show/993 154\#Text

3. Конвенція МОП про свободу асоціації та захист права на організацію № 87 від 9.07.1948р. URL: https://zakon.rada.gov.ua/laws/show/993_125\#Text

4. Freedom of Association. Compilation of decisions of the Committee on Freedom of Association / International Labour Office. Geneva: ILO, 6th edition, 2018. URL: https://ilo.primo.exlibrisgroup. com/discovery/delivery/41ILO_INST:41ILO_V2/1253169950002676?lang=en\&viewerServiceCode $=\mathrm{AlmaViewer}$

5. Декларація МОП основних принципів та прав у світі праці, 1998. URL: https://zakon.rada.gov.ua/ laws/show/993 260\#Text

6. Міжнародний пакт про економічні, соціальні i культурні права 1966 p. URL: https://zakon.rada.gov.ua/laws/show/995_042\#Text

7. Міжнародний пакт про громадянські та політичні права 1966 p. URL: https://zakon.rada.gov.ua/ laws/show/995_043\#Text

8. Свропейська соціальна хартія (переглянута) 1996 p. URL: https://zakon.rada.gov.ua/laws/ show/994_062\#Text 
9. Конвенціяпрозахистправлюдиниі основоположних свобод 1950 p.URL:https://zakon.rada.gov.ua/ laws/show/995 004\#Text

10. Угода про асоціацію між Україною, з однієї сторони, та Європейським Союзом, Свропейським співтовариством 3 атомної енергії і їхніми державами-членами, з іншої сторони, 29 травня 2014 p. URL: https://zakon.rada.gov.ua/laws/show/984_011\#Text

11. Соломінчук В.В. Участь професійних спілок у розбуддові соціально-правової держави (теоретико-правовий аспект): автореферат дис. к. ю. н. 12.00.01. Харків, 2018. 19 с.

12. Яцкевич I.I. Роль профспілок у захисті трудових прав та інтересів працівників. Кухня трудових прав: нариси про важливі інгредієнти: збірник статей. Київ: ВД Дакор, 2021. С. 106-114.

13. Informal economy. URL: https://www.ilo.org/global/topics/employment-promotion/informaleconomy/lang--en/index.html

14. Сімутіна Я.В. Трансформація ознак трудових правовідносин в умовах інформаційного суспільства / Сучасне право в епоху соціальних змін: Матеріали XI Міжнародної науково-практичної конференції, м. Київ, Національний авіаційний університет, 26 лютого 2021 р. Т. 2. Тернопіль: Вектор, 2021. С. 144-146.

15. Non-standard employment around the world: Understanding challenges, shaping prospects. ILO. Geneva, 2016. P. XXII. URL: https://www.ilo.org/global/publications/books/WCMS_534326/lang-en/index.htm.

16. New forms of employment. Research Report. Luxembourg: Publications Office of the European Union, 2015. URL: https://www.eurofound.europa.eu/publications/report/2015/new-forms-ofemployment

17. Tavits Gaabriel. Changing world of labour and social protection / Ефективність норм права : зб. наук. праць. Матеріали VII міжнар. наук.-практ. конф. (Київ, 17 лист. 2016 р.) / за заг. ред. Н.М. Пархоменко, М.М. Шумила, І.О. Ізарової. Київ: Ніка-Центр, 2016. С. 426.

18. Srnicek N., Williams A. Die Zukunft erfinden. Postkapitalismus und eine Welt ohne Arbeit. Berlin, 2016. $384 \mathrm{~S}$.

19. Tarifvertragsgesetz (TVG). URL: https://www.gesetze-im-internet.de/tvg/_ 12a.html

20. Groundbreaking agreement: Danes can now order takeaways with a clean conscience. URL: https://fagbladet3f.dk/artikel/danes-can-now-order-takeaways-clean-conscience?fbclid=IwAR2VqZY WuDOo5IjHHESaS9_3XN

21. Hannah Johnston, Chris Land-Kazlauskas. Organizing on-demand: Representation, voice, and collective bargaining in the gig economy. URL: https://www.ilo.org/wcmsp5/groups/public/---ed_ protect/---protrav/---travail/documents/publication/wcms_624286.pdf.

\section{References:}

1. Verkhovna Rada of Ukraine (1996). Konstytutsiia Ukrainy [Constitution of Ukraine]. Vidomosti Verkhovnoi Rady Ukrainy, no. 30, art. 141. Retrieved from: https://zakon.rada.gov.ua/laws/ show $/ 254 \% \mathrm{D} 0 \% \mathrm{BA} / 96-\% \mathrm{D} 0 \% \mathrm{~B} 2 \% \mathrm{D} 1 \% 80$ [in Ukrainian].

2. Statut Mizhnarodnoi Orhanizatsii Pratsi vid 28.06.1919 [ILO Constitution of June, 1919]. Retrieved from: https://zakon.rada.gov.ua/laws/show/993_154\#Text [in Russian].

3. Konventsiia MOP pro svobodu asotsiatsii ta zakhyst prava na orhanizatsiiu № 87 vid 09.07.1948 [ILO, Freedom of Association and Protection of the Right to Organise Convention, 1948, No. 87] Retrieved from: https://zakon.rada.gov.ua/laws/show/993_125\#Text [in Ukrainian].

4. Freedom of Association. Compilation of decisions of the Committee on Freedom of Association / International Labour Office. Geneva: ILO, 6th edition, 2018. Retrieved from: https://ilo.primo.exlibrisgroup.com/discovery/delivery/41ILO_INST:41ILO_V2/1253169950002676?lang=en\&viewerSer viceCode $=$ AlmaViewer

5. Deklaratsiia MOP osnovnykh pryntsypiv ta prav u sviti pratsi, 1998. [ILO Declaration on Fundamental Principles and Rights at Work, 1998] Retrieved from: https://zakon.rada.gov.ua/laws/ show/993_260\#Text [in Ukrainian].

6. Mizhnarodnyi pakt pro ekonomichni, sotsialni i kulturni prava, 1966. [International Covenant on Economic, Social and Cultural Rights, 1966]. Retrieved from: https://zakon.rada.gov.ua/laws/ show/995_042\#Text [in Ukrainian].

7. Mizhnarodnyy pakt pro hromadyans'ki ta politychni prava, 1966. [International Covenant on Civil and Political Rights, 1966]. Retrieved from: https://zakon.rada.gov.ua/laws/show/995_043\#Text [in Ukrainian]. 
8. Ievropeiska sotsialna khartiia (perehlianuta), 1996. [European Social Charter (revised), 1996] Retrieved from: https://zakon.rada.gov.ua/laws/show/994_062\#Text [in Ukrainian].

9. Konventsiia pro zakhyst prav liudyny i osnovopolozhnykh svobod, 1950 [Convention for the Protection of Human Rights and Fundamental Freedoms, 1950] Retrieved from: https://zakon.rada.gov.ua/ laws/show/995 004\#Text [in Ukrainian].

10. Uhoda pro asotsiatsiiu mizh Ukrainoiu, z odniiei storony, ta Yevropeiskym Soiuzom, Yevropeiskym spivtovarystvom $\mathrm{z}$ atomnoi enerhii $\mathrm{i}$ yikhnimy derzhavamy-chlenamy, $\mathrm{z}$ inshoi storony vid 29.05.2014 [Association Agreement between the European Union and the European Atomic Energy Community and their Member States, of the one part, and Ukraine, of the other part of 29 May, 2014] Retrieved from: https://zakon.rada.gov.ua/laws/show/984_011\#Text [in Ukrainian].

11. Solominchuk V.V. (2018) Uchast profesiinykh spilok u rozbudovi sotsialno-pravovoi derzhavy (teoretyko-pravovyi aspect): avtoreferat dys. k. yu. n. 12.00.01) [Participation of trade unions in the development of the social and legal state (theoretical and legal aspect): phd dissertation abstract]. Kharkiv, 2018. 19 s. [in Ukrainian].

12. Yatskevych I.I. (2021) Rol profspilok u zakhysti trudovykh prav ta interesiv pratsivnykiv. Kukhnia trudovykh prav: narysy pro vazhlyvi inhrediienty: zbirnyk statei. [The role of trade unions in protecting labor rights and interests of workers. The kitchen of labor rights: essays on important ingredients: a collection of articles] Kyiv: VD Dakor, 2021. S. 112. [in Ukrainian].

13. Informal economy. Retrieved from: https://www.ilo.org/global/topics/employment-promotion/informal-economy/lang--en/index.html

14. Simutina Ya.V. (2021) Transformatsiia oznak trudovykh pravovidnosyn v umovakh informatsiinoho suspilstva / Suchasne pravo v epokhu sotsialnykh zmin. zmin: Materialy XI Mizhnarodnoi naukovopraktychnoi konferentsii, Kyiv, Natsionalnyi aviatsiinyi universytet, 26.02.2021 [Transformation of signs of labor relations in the information society / Modern law in the era of social change: Proceedings of the XI International Scientific and Practical Conference, Kyiv, National Aviation University, February 26, 2021]. T. 2. Ternopil: Vektor, 2021, 2021. S. 144-146. [in Ukrainian].

15. ILO. Non-standard employment around the world: Understanding challenges, shaping prospects. Geneva, 2016. P. XXII. Retrieved from: https:/www.ilo.org/global/publications/books/ WCMS_534326/lang--en/index.html

16. New forms of employment. Research Report. Luxembourg: Publications Office of the European Union, 2015. Retrieved from: https://www.eurofound.europa.eu/publications/report/2015/new-formsof-employment

17. Tavits G. (2016) Changing world of labour and social protection // Efektyvnist norm prava : zb. nauk. prats. Materialy VII mizhnar. nauk.-prakt. konf. (Kyiv, 17 lyst. 2016 r.) / za zah. red. N.M. Parkhomenko, M.M. Shumyla, I.O. Izarovoi. Kyiv: Nika-Tsentr, 2016. S. 426.

18. Srnicek N., Williams A. Die Zukunft erfinden. Postkapitalismus und eine Welt ohne Arbeit [Invent the future. Post-capitalism and a world without work] Berlin, 2016. 384 S. [in German].

19. Tarifvertragsgesetz (TVG) [Collective Agreement Act]. Retrieved from: https://www.gesetze-im-internet.de/tvg/_ 12a.html [in German].

20. Groundbreaking agreement: Danes can now order takeaways with a clean conscience. Retrieved from: https://fagbladet3f.dk/artikel/danes-can-now-order-takeaways-clean-conscience?fbclid=IwAR2VqZY WuDOo5IjHHESaS9_3XN

21. Johnston H., Land-Kazlauskas C. (2019) Organizing on-demand: Representation, voice, and collective bargaining in the gig economy. Retrieved from: https://www.ilo.org/wcmsp5/groups/public/---ed_ protect/---protrav/---travail/documents/publication/wcms_624286.pdf

\section{Gluschenko M. P. The role of trade unions in protecting labour rights in the digital economy}

The article is dedicated to the study of the role and importance of trade unions for the defense and protection of labour rights and legitimate interests of workers in the digital economy and the development of nonstandard forms of employment, in particular, work on online platforms. It is emphasized that in today's conditions the role of trade unions in protecting social and labour rights is a complex issue, the solution of which requires systematic approaches to various functions of trade unions. Given the variety of forms of trade union protection, they cannot remain unchanged due to the transformations in the field of labour and employment due to the development of information technology, in particular, the spread of nonstandard forms of employment. 
It is noted that most of non-standard and new forms of employment usually involve the absence of direct dependence of the employee on the employer. The complex forms of employment are related to the development of the Internet and mobile devices, in which it is not always clear whether there is an employment relationship or not, and even more difficult to determine whether those involved in such forms of employment should be identified as employees in a standard employment relationship. All this necessitates the introduction of appropriate mechanisms that would allow the extension of collective bargaining to employees with non-standard (unstable) employment, in particular, employed on Internet platforms. One of the guarantees for the realization of such rights can be the inclusion of such workers in the circle of social partners by giving them an independent right to collective bargaining and / or representation in the labour market by industry unions.

Key words: trade unions, non-standard forms of employment, Internet platforms, the right to association, protection of labour rights. 
УДК 340.12

DOI https://doi.org/10.31392/NPU-nc.series18.2021.36.05

Заяць О. С.

\section{ІНТЕНЦІОНАЛЬНИЙ АНАЛІЗ СВІТОГЛЯДНИХ ОЗНАК ПРОФЕСІЙНОЇ АДВОКАТСЬКОЇ ДІЯЛЬНОСТІ}

У статті проведено інтенціональний аналіз світоглядних ознак професійної адвокатськоі діяльності, в межсах якого з 'ясовано, щзо професійна адвокатська діяльність відноситься до типу професій «людина - людина», для успішної реалізаиії в якому необхідно вміти легко встановлювати контакт із людьми, підтримувати спілкування та розуміти людей з їхніми психологічними особливостями та проблемами; володіти високим рівнем аналітичних здібностей, відмінними професійними знаннями. Обгрунтовано, що суть адвокатської діяльності полягає у наданні професійної правової допомоги клієнтам із метою досягнення справедливості виключно на основі законних та морально виправданих способів. Визначено, що здійснення професійної адвокатської діяльності відповідно до вимог закону сприяє: підвищенню рівня довіри до адвокатської діяльності шляхом формування позитивного іміджу адвокатури в державі; позитивному впливу на рівень правосвідомості, правової освіти та правомірної поведінки населення; функиіонуванню принципу верховенства права на території держави та пріоритетності прав і свобод людини, іï законних інтересів; самовдосконаленню адвоката як фахівия своєї справи, який сприяє досягненню справедливості виключно на основі законних та морально виправданих методів. Запропоновано трактувати професійну адвокатську діяльність як людиноорієнтовану професію, завданням якої є допомога людині з метою покращення рівня ї̈ життя. Взаємодіючи з людиною у прочесі надання їй правової допомоги, адвокат водночас взаємодіє $i$ з суспільством, $i$ з державою. Взаємодія із суспільством відбувається через того ж таки клієнта, який є частиною суспільства, а тому виражає його настрої та очікування; взаємодія з державою відбувається через уповноважених нею осіб та органи, інститути на здійснення функиій, які сприяють досягненню справедливості.

Ключові слова: інтениіональний аналіз, адвокатська діяльність, адвокат, верховенство права, суспільство, держава, право.

Вільне здійснення адвокатом своєї професійної діяльності є однією з ознак правової держави. Завдяки цьому положенню, яке закріплене в законі, реалізується низка інших прав та свобод людини, зокрема і право на правову допомогу як спосіб досягнення справедливості на основі законних та морально виправданих методів. Однак для того, щоб адвокат міг виконувати свою роботу ефективно, він повинен мати певні законодавчі гарантії, які б забезпечували йому можливість діяти відповідно до принципів адвокатської діяльності - незалежності, законності, конфіденційності, уникнення конфлікту інтересів.

Адже будь-який зовнішній вплив на адвоката нівелює його можливості для надання якісної правової допомоги своєму клієнту, створюючи бар'єр між ними, тому виникає недовіра до адвоката, з'являються сумніви у його компетентності, рівні моральних якостей; значно знижуються шанси на досягнення справедливості на основі законних та морально виправданих способів. «Адвокатура - публічний інститут суспільства. Держава зобов'язалася перед суспільством і кожним його членом забезпечити всім і кожному допомогу з питань права. Однак таку допомогу надаватиме не чиновник, а представник громадянського суспільства, що знає право. Держава зобов'язана створити таким знавцям права сприятливі умови для виконання їхніх функцій. Такими знавцями права $є$ адвокати» [1, с. 13].

Звідси випливає один із принципів діяльності адвоката - принцип незалежності. Цей принцип є сутнісним, оскільки він визначає правову природу адвокатської діяльності, характеризує іiї статус, виступає гарантією ефективного захисту прав і свобод людини. Завдяки існуванню принципу незалежності адвокатської діяльності наявні механізми захисту прав і свобод людини починають функціонувати реально, що сприяє реалізації принципу верховенства права та досягненню кінцевої мети правосуддя - справедливості. Т. Демчина визначає незалежність адвоката у професійній діяльності як такий його правовий стан, що дає йому змогу незалежно 
від будь-якого зовнішнього впливу, тиску чи втручання здійснювати на підставі закону свою професійну діяльність із надання професійної правничої допомоги клієнту, а незалежність адвокатури як встановлений законом правовий стан органів адвокатського самоврядування, що дозволяє їм самостійно та незалежно вирішувати питання своєї внутрішньої організації, а також інші завдання, закріплені у законодавстві [2, с. 20].

Я пропоную розглядати незалежність адвоката у кількох аспектах. По-перше, це незалежність особистісних переконань від зовнішніх впливів. Адвокат поряд із відмінним знанням законодавства повинен володіти усвідомленою чіткою системою моральних цінностей та орієнтирів. Відповідно до цієї системи він вибудовує свою як побутову, так і професійну поведінку; відступити від неї він не зможе навіть задля досягнення поставленої мети або ж прагнутиме досягти її виключно на основі законних та морально виправданих способів. Якщо людина обдумувала певні моральні цінності, зіставляла їх із уже прийнятими для себе цінностями та усвідомлено прийняла як орієнтири для себе, то вони сформують стійку систему поведінки, вплинути на яку з метою спонукання до вчинення одноразової неправомірної дії, яка несумісна з особистими моральними цінностями, буде неможливо. По-друге, це незалежність від органів та інститутів влади. Незалежність адвоката гарантується законом, однак для того, щоб цей принцип діяв на практиці, а не лише декларувався, попри бажання самого адвоката необхідно об'єднати зусилля адвокатської спільноти, аби не йти на компроміси із владою, а здійснювати свою професійну діяльність виключно в межах закону. Те саме стосується ситуацій, коли адвокат виступає захисником у справах «людина - держава», де держава апріорі має більше шансів на захист своїх позицій, ніж пересічна людина. Саме можливість отримання правової допомоги від незалежного адвоката зрівнює їхні шанси на досягнення справедливості. По-третє, незалежність від людей, які володіють певним впливом у суспільстві. Щоб не потрапити в залежність від впливових у суспільстві людей, адвокат у своїй поведінці не повинен допускати жодних порушень правових норм, сумнівних знайомств. Адже усе це може у подальшому спонукати його діяти в інтересах певних осіб, які мають на меті здійснення протиправної діяльності. А це може зашкодити виконанню професійного обов'язку із захисту прав, свобод та законних інтересів клієнта. По-четверте, принцип незалежності адвоката випливає з його особистості, з готовності розвиватися, щоби відповідати тим принципам та вимогам, які висуваються до такого виду професійної діяльності та продиктовані часом, розвитком суспільства, держави і людини. Своєю професійною поведінкою, складниками якої є право і мораль як системи світосприйняття, адвокат може впливати на правослухняну поведінку в суспільстві.

«Практична реалізація принципу незалежності адвоката безпосередньо зумовлена дуалістичною природою інституту адвокатури у правовій державі. 3 одного боку, адвокат - необхідний елемент у системі правосуддя, а з іншого - професійний консультант громадян та їх інституцій (об’єднань). Цю бінарну функцію адвокат може реалізовувати лише в тому разі, якщо йому забезпечена необхідна незалежність. Саме ця незалежність створює адвокату можливість співвідносити і врівноважувати двосторонні інтереси та займати певну правову позицію між двома полюсами» [3, с. 16]. Без адвоката правосуддя не могло би бути справедливим, оскільки не міг би бути забезпечений принцип рівності сторін, реалізоване право на професійний захист. Отже, з упевненістю необхідно констатувати, що суть адвокатської діяльності полягає у наданні професійної правової допомоги клієнтам із метою досягнення справедливості виключно на основі законних та морально виправданих способів. «Справедливість у правах людини - це забезпечена юридична рівність для кожного індивіда, можливість володіти та користуватися певною свободою. При цьому особа, розпоряджаючись належними їй правами, повинна усвідомлювати, що такими ж правами наділені й інші люди, а тому вона зобов’язана їх поважати. Забезпечуючи кожному юридично рівні можливості, держава визначає таким чином межі свобод і встановлює норму про те, що користування особою визнаними за нею правами не повинно порушувати права інших людей» [4, с. 20].

Професійна адвокатська діяльність належить до типу професій «людина - людина», для успішної реалізації в якому необхідно вміти легко встановлювати контакт із людьми, підтримувати спілкування та розуміти людей з їхніми психологічними особливостями та пробле- 
мами; володіти високим рівнем аналітичних здібностей, відмінними професійними знанням. У пригоді стануть такі якості, як комунікабельність, швидкість реакції, стресостійкість. Окрім права, цю професію формують мораль та психологія. Право та мораль характеризуються синкретизмом, оскільки право сформувалося на основі моральних норм та приписів, які діяли на ранніх етапах формування державності. І сьогодні правові норми, санкціоновані державою, цілком узгоджуються з моральними цінностями. Якщо правом регулюються відносини в системах «людина - людина» та «людина - держава», то мораль поряд із цими двома системами апелює ще й до взаємин людини із самою собою, з ії сумлінням. Психологія як наука про людину та іiі внутрішню сутність є вкрай важливою, адже допомагає адвокатові краще порозумітися 3 клієнтом, з іншими людьми, котрі мають пряме або опосередковане відношення до справи, якою займається адвокат, а також пізнати себе. Саме з такої тріади можна виділити всі основні ознаки професійної адвокатської діяльності, які ми умовно зарахували до трьох груп: 1) організаційні, 2) професійні, 3) етичні. У сукупності ці три групи ознак характеризують професійну адвокатську діяльність як сферу суспільної діяльності, поряд із цим визначаючи і вимоги до професії загалом та вимоги до представника професії як фахівця зокрема.

Професійна адвокатська діяльність полягає насамперед у роботі з людиною. Це людиноорієнтована професія, завданням якої є допомога людині з метою покращення рівня її життя. Взаємодіючи з людиною у процесі надання їй правової допомоги, адвокат водночас взаємодіє і з суспільством, і з державою. Взаємодія із суспільством відбувається через того ж таки клієнта, який є частиною суспільства, а тому виражає його настрої та очікування; взаємодія 3 державою відбувається через уповноважених нею осіб та органи, інститути на здійснення функцій, які сприяють досягненню справедливості.

Соціальність як ознака професійної адвокатської діяльності проявляється у ії соціальній сутності як явища; «це його роль у задоволенні потреб, інтересів певного суб'єкта - суспільства загалом чи якоїсь його частини: народу, нації, прошарку, групи тощо. Інакше кажучи, сутність явища соціальної дійсності - це його значення для існування й розвитку суб'єкта» [5, с. 23-25]. Адвокатська діяльність як явище соціальної дійсності покликана задовольнити потребу людини в захисті, адже зазвичай до адвоката звертаються за захистом чи відновленням своїх порушених прав, свобод та законних інтересів. I лише той адвокат зможе задовольнити цю потребу, який, окрім необхідних професійних якостей та бездоганного знання законодавства, володіє й високими моральними принципами, завдяки чому може досягти справедливості на основі законних та морально виправданих засобів.

У цьому контексті ще однією ознакою є компетентність. Це поєднання практичних знань, умінь та навичок, завдяки засвоєнню яких людина може ефективно виконувати певну професійну діяльність. Задля того, щоб досягти мети професії адвоката - надання якісної правової допомоги клієнту та відновлення його прав, свобод і законних інтересів, - компетентність адвоката не повинна викликати у клієнта жодних сумнівів. 3 метою досягнення високого рівня компетентності адвокат повинен: 1) постійно вдосконалювати свій професійний рівень знань; 2) добросовісно працювати над кожною справою, у якій він виступає захисником чи консультантом; 3) неухильно дотримуватися вимог закону та моральних принципів під час здійснення професійної діяльності; 4) своєю щоденною поведінкою утверджувати цінність закону як регулятора суспільних відносин в сучасних суспільстві та державі.

«Визначення професійної компетентності містить низку взаємопов'язаних складових частин: гностичну (або когнітивну), що відображає наявність необхідних професійних знань; регулятивну, що дає змогу використовувати професійні знання для розв'язання професійних завдань; рефлексивно-статусну, що надає право завдяки визнанню авторитетності діяти певним чином; нормативну характеристику, що відображає коло повноважень, сферу професійного знання; комунікативну характеристику, оскільки поповнення знань або практична діяльність завжди здійснюються у процесі спілкування та взаємодії» [6, с. 54].

Сьогодні одним з найбільш актуальних напрямів розвитку компетентності адвоката, окрім вдосконалення знання законодавства, є необхідність чіткої практичної спрямованості. Практична спрямованість професійної адвокатської діяльності актуалізує роботу адвоката у сфері 
захисту прав, свобод і законних інтересів людини, а також допомагає реалізувати на практиці задекларовані у законі права та свободи людини, а також сприяє підвищенню ефективності роботи механізмів, пов'язаних із процесами відновлення порушених прав, свобод і законних інтересів людини.

Окрім означених вище ознак, $є$ ще одна, не менш важлива їхня група, що характеризує саме етичні виміри професійної адвокатської діяльності.

Послуговування особистою усвідомленою системою ціннісних орієнтацій у повсякденному житті та професійній діяльності є важливим для кожного, однак для представників професії адвоката воно має вкрай актуальне значення, адже саме від цінностей адвоката залежить спосіб досягнення справедливості під час роботи з клієнтом. Тобто чи будуть використані виключно законні та морально виправдані методи для досягнення справедливості, чи адвокат використовуватиме всі доступні йому методи та способи, аби повернути справу на користь свого клієнта. Ті цінності, орієнтири, установки, які адвокат використовує у повсякденному житті, він покладе в основу своєї професійної діяльності. Саме від моральних цінностей залежать мотиви поведінки людини та способи досягнення мети. «Ціннісно-орієнтаційна сфера $\epsilon$ цілісним утворенням особистості, що певною мірою визначає мотивацію ії поведінки, а відтак створює єдину мотиваційну структуру, де цінності тісно пов'язані з потребами, мотивами, спонуканнями установками, поведінкою. Мотиви є основною рушійною силою, збудником поведінки людини, а отже, і основним стимулятором для розвитку особистості. Ціннісні орієнтації людини входять до структури мотиваційної сфери людини та визначаються як загальні орієнтири особистості, їі уявлення про ідеальні параметри існування» [7, с. 148]. Ціннісні орієнтації, з якими людина «входить» у професію, становлять ту основу, фундамент, на який потім нашаровуються професійні цінності. 3 цим може бути пов'язана й ситуація, коли одні сприймають ту чи іншу професійну цінність, а інші - ні, причиною такого можуть бути різні базові ціннісні системи у людей.

Професійні цінності адвокатської діяльності виражені у Правилах адвокатської етики. «Правила адвокатської етики мають на меті уніфіковане закріплення традицій і досвіду української адвокатури у сфері тлумачення норм адвокатської етики, а також загальновизнаних деонтологічних норм і правил, прийнятих у міжнародному адвокатському співтоваристві» [8]. Правила професійної етики адвоката продиктовані часом і вимогами до професії у громадянському суспільстві та правовій державі. Сьогодні ми переживаємо своєрідний етичний поворот до загальнолюдських цінностей, які регулювали життя людей упродовж століть, оскільки людство врешті-решт зрозуміло, що розвиток держави та прогрес суспільства без них неможливий. Аналогічною є ситуація із професійними цінностями адвоката, які також беруть початок від моральних цінностей, однак є дещо доповненими актуальними для держави, суспільства та людини приписами.

Підсумовуючи, відзначу, що ознаки професійної адвокатської діяльності - це сукупність властивостей та факторів юридичної діяльності, які виникли у процесі її здійснення та характеризують їі як певний специфічний вид професійної діяльності із захисту прав, свобод та законних інтересів людини. Завдяки якісній професійній адвокатській діяльності, що об'єднує перелічені ознаки, у суспільстві та державі з'являється можливість гарантувати людині практичну можливість користуватися своїми правами і свободами. Держава та суспільство спрямовують свою діяльність на те, щоби права і свободи людини були реалізовані в повному обсязі, що сприяло б розвитку особистості, поступово впливало на чисельність ситуацій, які порушують права і свободи людини. За наявності ефективного механізму відновлення порушених прав і свобод людини та відповідного покарання винних за це кількість таких ситуацій поступово зменшуватиметься. Цьому сприятиме усвідомлення невідворотності покарання за протиправні діiі, ефективного функціонування механізму захисту та відновлення порушених прав і свобод людини. Досягнення справедливості виключно на основі законних та морально виправданих методів сприятиме утвердженню ефективного функціонування задекларованого у законі механізму відновлення порушених прав і свобод та захисту людини; допоможе знизити рівень зловживання правом. Знаючи, що за порушення правових норм обов'язково настане покарання 
відповідно до закону, значна частина людей свідомо уникатиме цього. За вчинення правопорушень та злочинів їхні права також будуть обмежені, а це спонукатиме до правослухняної поведінки, реалізації задекларованих цінностей правової держави та громадянського суспільства. Людина, її права та свободи є найбільшою цінністю для правової держави та громадянського суспільства, тому діяльність держави спрямовується на їх забезпечення, що значно полегшується з допомогою професійної адвокатської діяльності.

\section{Використана література:}

1. Ганкевич Л. Союз Українських Адвокатів у Львові: матеріали й зауваги з нагоди десятиліття. Львів: Накладом СУА, 1938. 38 с.

2. Демчина Т.Ю. Співвідношення принципу незалежності адвокатури з іншими правовими категоріями. Форум права. 2020. № 4. C. 15-23. URL: https://forumprava.pp.ua/files/015-023-2020-4FP-Demchyna_4.pdf

3. Бочуляк Н. Незалежність як домінанта адвокатського самоврядування. Вісник Національного університету «Львівська політехніка». Серія: Юридичні науки. 2019. Вип. 22. С. 12-19.

4. Федіна Н.В. Правова справедливість як засіб забезпечення соціальної цінності правових норм. Прикарпатський юридичний вісник. 2016. Вип. 6 (15). С. 20-24.

5. Рабінович П. Правова держава: яка її соціальна сутність? «На шляху до правової держави»: матеріал. Львівської регіональної науково-правової конференції. Львів, 1992. С. 21-28.

6. Баліцька М.О. Комунікативна компетентність адвоката як предмет дослідження в юридичній психології. Південноукраӥнський правничий часопис. 2017. № 3. С. 54-57.

7. Ткаченко Н., Антонюк А. Особливості зв'язку професійної мотивації з ціннісними орієнтаціями у адвокатів. Збірник наукових праць РДГУ. 2020. Вип. 15. С. 148-154.

8. Правила адвокатської етики. URL: https://zakon.rada.gov.ua/rada/show/n0001891-17\#Text

\section{References:}

1. Hankevych L. (1938). Soiuz Ukrainskykh Advokativ u Lvovi: materialy y zauvahy z nahody desiatylittia [Union of Ukrainian Lawyers in Lviv: materials and remarks on the occasion of the decade]. Lviv: Nakladom SUA. 38 s. [in Ukrainian].

2. Demchyna T.Yu. (2020). Spivvidnoshennia pryntsypu nezalezhnosti advokatury z inshymy pravovymy katehoriiamy [Correlation of the principle of independence of the bar with other legal categories]. Forum prava. No 4. S. 15-23. URL: https://forumprava.pp.ua/files/015-023-2020-4-FP-Demchyna_4. pdf [in Ukrainian].

3. Bochuliak N. (2019). Nezalezhnist yak dominanta advokatskoho samovriaduvannia [Independence as a dominant self-governing self-government]. Visnyk Natsionalnoho universytetu «Lvivska politekhnika». Seriia: Yurydychni nauky. Vyp. 22. S. 12-19. [in Ukrainian].

4. Fedina N.V. (2016). Pravova spravedlyvist yak zasib zabezpechennia sotsialnoi tsinnosti pravovykh norm [Legal justice as a means of ensuring the social value of legal norms]. Prykarpatskyi yurydychnyi visnyk. 2016. Vyp. 6 (15). S. 20-24. [in Ukrainian].

5. Rabinovych P. (1992). Pravova derzhava: yaka yii sotsialna sutnist? «Na shliakhu do pravovoi derzhavy» [The rule of law: what is its social essence? "On the way to the rule of law"]: material. Lvivskoi rehionalnoi naukovo-pravovoi konferentsii. Lviv, 1992. S. 21-28. [in Ukrainian].

6. Balitska M.O. (2017). Komunikatyvna kompetentnist advokata yak predmet doslidzhennia v yurydychnii psykholohii [Communicative competence of a lawyer as a subject of research in legal psychology]. Pivdennoukrainskyi pravnychyi chasopys. No 3. S. 54-57. [in Ukrainian].

7. Tkachenko N., Antoniuk A. (2020). Osoblyvosti zviazku profesiinoi motyvatsii z tsinnisnymy oriientatsiiamy u advokativ [Peculiarities of connection of professional motivation with value orientations of lawyers]. Zbirnyk naukovykh prats RDHU. Vyp. 15. S. 148-154. [in Ukrainian].

8. Pravyla advokatskoi etyky [Rules of lawyer ethics]. (2017). URL: https://zakon.rada.gov.ua/rada/ show/n0001891-17\#Text

\section{Zaiats $O$. S. Intentional analysis of world views of professional advocacy}

The article provides an intentional analysis of the worldview features of professional advocacy, which found that professional advocacy belongs to the type of professions "man - man", for successful implementation in which it is necessary to be able to easily establish contact with people, maintain 
communication and understand people with their psychological features and problems; have a high level of analytical skills, excellent professional knowledge. It is substantiated that the essence of advocacy is to provide professional legal assistance to clients in order to achieve justice solely on the basis of legal and morally justified means. It is stipulated that the implementation of professional advocacy in accordance with the requirements of the law contributes to: increasing the level of trust in advocacy by forming a positive image of the bar in the state; positive impact on the level of legal awareness, legal education and lawful behavior of the population; promoting the functioning of the principle of the rule of law in the territory of the state and the priority of human rights and freedoms, its legitimate interests; self-improvement of a lawyer as a specialist in his field, which contributes to the achievement of justice solely on the basis of legal and morally justified methods. Therefore, it has been established and proposed to interpret the professional legal activity as a human-oriented profession, the task of which is to help a person in order to improve his standard of living. Therefore, interacting with a person in the process of providing him with legal assistance, the lawyer at the same time interacts with society and the state. Interaction with society occurs through the same client who is part of society, and therefore expresses his moods and expectations; interaction with the state takes place through its authorized persons and bodies, institutions to perform functions that contribute to the achievement of justice.

Key words: intentional analysis, advocacy, lawyer, rule of law, society, state, law. 


\author{
УДК 351.713:354.42.44 \\ DOI https://doi.org/10.31392/NPU-nc.series18.2021.36.06
}

Зицик С. Г.

\title{
ПРАВОВИЙ РЕЖИМ ІНФОРМАЦЇ ПРО ПЛАТНИКІВ ПОДАТКІВ В УКРАЇНІ
}

Стаття присвячена правому врегулюванню порядку надання податковими органами інформаиії про платників податків для третіх осіб, отриманої в результаті діяльності циих органів. Досліджено порядок переходу податкових органів на електронний документообіг. Електронні відомості про платника податків використовуються як доказова база як під час розгляду кримінальних i адміністративних справ, так і під час здійснення податкових процедур, пов'язаних із встановленням та узгодженням податкових зобов'язань. Розглядається питання допустимості застосування інформаційних баз даних про платників податків як доказової бази в адміністративних проиедурах та судових проиесах. Вказується на неприпустимість використання податковими органами динамічної інформації про платника податків із сайтів, щчо періодично оновлюються, без додаткового підтвердження иих відомостей. Пропонується конкретизувати перелік відомостей про платників податків (сумлінних), які заборонено розповсюджувати без їхньої згоди, - відомостей, щуо є конфіденційними для інших осіб і не є відкритою інформацією. Досліджено визначені законодавством види «таємниць» у різних сферах публічної діяльності, суть яких полягає в нерозголошенні відомостей, отриманих посадовими особами під час здійснення їхньої професійної діяльності. Обгрунтовується необхідність внесення змін до Податкового кодексу Украӥни у частині визначення терміна «податкова таємниия»; покладення обов'язку зберігати податкову таємницю на податкові органи (замість визначеного сьогодні права платників податків на нерозголошення інформачії про них); виключення з переліку конфіденційної податкової інформачії тієї, щзо є відкритою для третіх осіб. Враховуючи значний суспільний інтерес та суспільну значущість інформащії про осіб, які завдають збитки фінансовій безпеиі держсави, пропонується до суспільно необхідної інформації віднести інформацію про платників податків та бенефіціарів (політичних, державних діячів), які своїми активними протиправними діями перешкоджають надходженню публічних коштів у вигляді податків та зборів.

Ключові слова: податкова таємниця, податкова інформація, правовий режим інформації про платників податків.

За сприяння Міністерства цифрової трансформації України, завдяки стрімкому розвитку інформаційних технологій та телекомунікаційних систем податкові органи, як і інші органи державної виконавчої влади, поступово перейшли на здійснення електронного обміну листами та організаційно-розпорядчими документами.

Для забезпечення ефективної фінансової діяльності суб'єктів оподаткування активно впроваджується обмін інформацією з податковими органами через електронний кабінет платника податків, для удосконалення процедур адміністрування податків застосовується інформаційна система IC «Податковий блок» тощо. Інформація з реєстраторів розрахункових операцій в автоматичному режимі передається до системи обліку реєстраторів розрахункових операцій Державної податкової служби України. За таких умов зберігання та накопичення інформації про платників податків здійснюється в електронному вигляді, що викликає потребу впровадження нових підходів до контролю за їі обігом.

Дослідженнями правового статусу податкової інформації займалися Г.К. Авдєєва, Є.Ф. Збінський, І.М. Проць, О.А. Мандзюк, В.С. Цимбалюк, В.А. Ліпкан, Р.А. Калюжний, О.В. Шепета, I.I. Бабін, Б.А. Кормич, однак у дослідженнях науковців належної уваги не приділено можливості віднесення певної інформації про платників податків до суспільно необхідної.

Податкові органи як розпорядники інформації про платників податків зобов'язані забезпечити конфіденційність отриманої інформації за допомогою програмних засобів захисту. При цьому значно зростають ризики поширення податкової інформації працівниками податкових органів, що звільнилися з роботи. Варто посилити контроль за забезпеченням охорони конфіденційної інформації та підвищити міру відповідальності за неправомірне розповсюдження інформації з податкових баз даних. 
Ці завдання покладено на Управління охорони державної таємниці, технічного та криптографічного захисту інформації ДПС України, яке, зокрема, забезпечує охорону державної таємниці, технічний захист інформації, контроль за його станом; організацію криптографічного захисту інформації з обмеженим доступом та контроль його стану; організацію та координацію заходів забезпечення антивірусного захисту та кіберзахисту інформації, організацію пропускного режиму в органах державної податкової служби [11].

Отже, платники податків, повідомляючи податковим органам конфіденційну інформацію, мають право розраховувати на надійність захисту податкових баз даних, унеможливлення їх використання у приватних інтересах.

Електронні відомості про платників податків, що містяться у податкових базах даних, використовуються як доказова база як під час розгляду кримінальних і адміністративних справ і під час здійснення податкових процедур, пов'язаних із визначенням та узгодженням податкових зобов'язань.

Електронні докази відрізняються від інших джерел доказів (показань, речових доказів, документів, висновків експертів) тим, що вони створені за допомогою електронних пристроїв, зберігаються та розповсюджуються лише за допомогою електронних носіїв інформації та комп'ютерних або телекомунікаційних мереж. Вони стають доступними для сприйняття людиною лише після обробки засобами електронної техніки з відповідним програмним забезпеченням. Електронні докази легше змінити чи підробити, ніж традиційні форми доказів, тому питання забезпечення їх належності і допустимості $є$ вкрай актуальними [1].

Г.К. Авдєєва до причин низького рівня постановлення обвинувальних вироків і притягнення винних у несплаті податків до відповідальності відносить недосконалість зібраної співробітниками слідчих органів доказової бази через проблеми використання електронних (цифрових) доказів. Виявлення, фіксація і використання електронних доказів у процесі доказування викликає певні труднощі через стрімкий розвиток інформаційних технологій, швидкі зміни поколінь цифрової техніки та відсутність визначення поняття «електронні докази» у Кримінальному процесуальному кодексі України [1].

Суди нерідко відмовляються визнавати електронні листи як належні докази у справі; досліджуючи такі докази, суди вказують на неможливість визначити авторів електронних листів; виникають проблеми з ідентифікацією електронних цифрових підписів. У судовій практиці поширені випадки відхилення електронних листів як неналежної доказової бази з причин відсутності електронних цифрових підписів, які є обов'язковими реквізитами електронних документів [12].

Зібрану з різноманітних джерел інформацію про платників податків податкові органи використовують під час прийняття необхідних рішень.

Беззаперечно актуальним є використання у доказуванні податкових правопорушень податкової інформації, що міститься в інформаційних базах податкових органів та підтверджена прикріпленими копіями паперових документів чи документами у належному цифровому форматі та з використанням кваліфікованого електронного підпису (які неможливо підробити).

Однак суперечливим є використання податковими органами динамічної інформації про платника податків із сайтів, що періодично оновлюються, наприклад визначення статусу нерезидента за допомогою сайтів іноземних державних органів (до моменту вирішення справи статус нерезидента може бути зміненим, поновленим; дозвільний документ може бути анульованим, строк його дії може бути завершеним, продовженим) та вітчизняних сайтів із переліком дозвільних документів. Для підтвердження таких відомостей про платника податків варто отримувати додаткову інформацію від дозвільних (реєстраційних) органів, актуальну станом на відповідну дату, з якою пов'язується виникнення, припинення чи зміна податкових правовідносин.

Враховуючи зміст статті 21 Закону України «Про інформацію» [10], будь-які відомості про платника податків - фізичну особу є конфіденційними і поширюються за його згодою або у випадках, прямо передбачених законодавством. Платник податків - юридична особа може обмежити інформацію про себе. 
Водночас згідно із статтею 17 Податкового кодексу України [8] платник податків має право на нерозповсюдження про нього будь-яких відомостей незалежно від статусу юридичної чи фізичної особи, отриманих під час виконання службових обов'язків. $Є$ два виключення щодо можливого поширення такої інформації: за згодою платника податків або за прямим приписом відповідного Закону.

В Україні офіційно термін «податкова таємниця», на відміну від деяких зарубіжних країн та наукової літератури, не застосовується. Водночас, за аналогією з податковою таємницею, вітчизняним податковим законодавством врегульований правовий статус державної, комерційної, банківської таємниці, розповсюдження якої про платника податків (незалежно від статусу юридичної чи фізичної особи) забороняється.

Слід зазначити, що правовими нормами інших галузей права національного законодавства визначено правовий режим адвокатської таємниці, нотаріальної таємниці, таємниці заповіту, таємниці кореспонденції, таємниці листування, телефонних розмов, телеграфної та іншої кореспонденції, лікарської таємниці, таємниці особистого життя, професійної таємниці на ринках капіталу та організованих товарних ринках, таємниці голосування, таємниці сповіді, таємниці усиновлення (удочеріння), охоронюваної законом таємниці (у кримінальних справах), таємниці нарадчої кімнати тощо. Правова природа їх виникнення та застосування аналогічна поняттю «податкова таємниця» і полягає в нерозголошенні відомостей, отриманих посадовими особами під час здійснення їхньої професійної діяльності.

Інформація з обмеженим доступом повинна мати всі ознаки інформації в її законодавчому визначенні з урахуванням класифікуючих ознак, які мають їі складники (таємна, конфіденційна та службова інформація) [7].

В.А. Ліпкан поділяє методи обмеження доступу до інформації на законні і незаконні. Конфіденційна інформація розглядається ним як інформація винятково приватних суб' єктів, яка може бути дуже різноманітною. Основними їі ознаками є те, що вона не є загальновідомою, а відома лише певному приватному суб'єкту (суб'єктам), і він на власний розсуд вирішує, як і коли її поширювати чи обмежувати доступ до неї [7].

С. Ссімов до конфіденційної інформації відносить персональні дані, професійну таємницю, таємницю слідства і судочинства, службову інформацію, комерційну таємницю [3].

I.П. Кушнір, характеризуючи правовий режим інформації з обмеженим доступом, звертає увагу на необхідність чіткого розмежування видів інформації з обмеженим доступом для визначення обсягу та меж правового режиму і вибору конкретних заходів (інструментів) правового впливу. Правовий режим інформації з обмеженим доступом ним розглядається як встановлені законодавством процедури та порядок надання дозволу, доступу, охорони, захисту, а також здійснення діяльності з інформацією, яка становить значну цінність [5].

Є.Ф. Збінський правовий режим податкової таємниці визначає як особливий порядок правового регулювання суспільних відносин, що здійснюються за допомогою системи спеціальних юридичних засобів у сфері конфіденційної, незагальнодоступної інформації платника податків, що стала відома податковому органу у зв'язку з виконанням покладених на нього службових обов'язків, передбачених податковим законодавством [4].

I.M. Проць, розглядаючи податкову таємницю в контексті законодавства зарубіжних країн, зробив висновок про необхідність надати податковій таємниці особливого статусу, виділивши іiі з числа професійних таємниць, а також доводить необхідність передбачення в законодавстві більш суворих вимог до обігу відомостей, що становлять податкову таємницю [13].

Розглянувши погляди вчених на правовий режим інформації про платника податків, варто зазначити про необхідність імплементації до національного законодавства поняття податкової таємниці, а також покладення на контролюючі податкові органи обов'язку вчинення певної сукупності дій або утримання від їх здійснення щодо податкової таємниці (нині це право платника податків).

Відповідно до вимог цивільного законодавства, підозрювана у вчиненні злочину особа, затримана чи обвинувачена особа та особа, що притягується до адміністративної відповідаль- 
ності, мають право на неоприлюднення свого імені до прийняття остаточного рішення у відповідній справі (вирок, постанова).

Згідно зі статтею 29 Закону України «Про інформацію» [10] інформація з обмеженим доступом може бути поширена, якщо вона $є$ суспільно необхідною, $є$ предметом суспільного інтересу, а право громадськості на отримання інформації значно перевищує можливу шкоду (можливі збитки) від поширення такої інформації.

Перелік видів інформації, що може бути предметом суспільного інтересу, не є вичерпним. Гнучкість законодавства в цьому аспекті виправдано надає судам можливість визначати, чи $€$ конкретна інформація суспільно необхідною, з урахуванням індивідуальних обставин справи. Інформація може вважатися суспільно необхідною, якщо ії поширення сприяє дієвому контролю за надходженням та витрачанням публічних коштів [12].

На нашу думку, до суспільно необхідної інформації необхідно віднести інформацію про платників податків та бенефіціарів (політичних, державних діячів), які своїми активними протиправними діями перешкоджають надходженню публічних коштів у вигляді податків та зборів.

Право на доступ до інформації, якою володіють органи публічної влади, є основоположним правом людини та гарантією функціонування демократичної держави [2].

Держава не може обмежити право на доступ, наперед окресливши межі його застосування, тобто виключивши певні категорії відомостей із сфери цього права. Закон не може поділяти інформацію на завжди відкриту та завжди закриту. Це було би внутрішньо суперечливим і, відповідно, неприродним. Не може бути віднесена до конфіденційної інформація щодо використання бюджетних коштів [2]. Яскравим прикладом використання бюджетних коштів є бюджетне відшкодування податку на додану вартість, щодо якого суб'єкти господарювання, які професійно займаються незаконним бюджетним відшкодуванням цього податку, виявляють підвищений інтерес.

Згідно із Законом Закон України «Про доступ до публічної інформації» [9] обмеження доступу до інформації здійснюється за дотримання сукупності таких вимог: по-перше, виключно в інтересах національної безпеки, територіальної цілісності або громадського порядку з метою запобігання заворушенням чи злочинам, для охорони здоров'я населення, для захисту репутації або прав інших людей, для запобігання розголошенню інформації, одержаної конфіденційно, або для підтримання авторитету й неупередженості правосуддя; по-друге, розголошення інформації може завдати істотної шкоди цим інтересам; по-третє, шкода від оприлюднення такої інформації переважає суспільний інтерес в іiі отриманні.

О.С. Твердохліб стверджує, що зарахування інформації, яка потенційно може становити суспільний інтерес, до категорії «для службового користування», таємної чи конфіденційної та відсутність відповідного висновку розпорядника інформації щодо наявності хоча б однієї із трьох підстав «трискладового тесту» означає, що законних підстав для обмеження доступу до інформації немає, а відмова у доступі до публічної інформації вважається законодавцем необгрунтованою [14].

Оскільки предметом суспільного інтересу є інформація, яка забезпечує реалізацію конституційного обов'язку сплачувати податки і збори в порядку і розмірах, встановлених Законом, вважаємо суспільною необхідністю виключення з переліку інформації, яка становить «податкову таємницю», відомостей про назву платників податків, а також про бенефіціарів (політичних та публічних діячів), які містять ознаки фіктивності, беруть участь у складно структурованих схемах з ухилення від оподаткування, були притягнуті до кримінальної відповідальності за вчинення податкових злочинів.

До податкових органів значна частина інформації про платників податків надходить із відкритих джерел даних. Ці відомості про суб’єктів господарювання, потрапляючи до податкових органів, автоматично стають конфіденційними відомостями про платників податків і не можуть бути надані третім особам у загальному порядку.

Враховуючи значні обсяги інформації, що надходять до податкових органів, вважаємо, що в Податковому кодексі України необхідно конкретизувати перелік відомостей про платників 
податків (сумлінних), які заборонено розповсюджувати без їхньої згоди, - відомостей, що $\epsilon$ конфіденційними для інших осіб і не є відкритою або ж суспільно необхідною інформацією.

\section{Використана література:}

1. Авдєєва Г.К. Проблеми використання електронних доказів у протидії правопорушенням у податковій сфері. Протидія мінімізації сплати податків: світовий досвід та практика України : збірник матеріалів III Науково-практичного круглого столу, м. Ірпінь, 15 травня 2020 р. Ірпінь : НДІ фіскальної політики, 2020. С. 84-86.

2. Головенко Р., Котляр Д., Слизьконіс Д. Доступ до публічної інформації : посібник із застосування «трискладового тесту». Київ : ЦПСА, 2014. 152 с.

3. Єсімов С., Ковалів М., Скриньковський Р. Правові режими службової інформації в Україні. Traektoriâ Nauki = Path of Science. 2018. Vol. 4. № 4. C. 7001-7012.

4. Збінський Є. Ф. Правовий режим податкової таємниці в Україні : автореф. дис. ... канд. юрид. наук : 12.00.07. Запоріжжя, 2016. 22 с.

5. Кушнір І.П. Правовий режим інформації з обмеженим доступом у діяльності Державної прикордонної служби України. Право та державне управління. 2019. № 3 (36). С. 180185.

6. Лациба М.В., Хмара О.С., Андрусів В.В. Методичні рекомендації щодо практичного впровадження Закону України «Про доступ до публічної інформації». Укр. незалеж. центр політ. дослідж. Київ : Агентство «Україна», 2012. 164 с.

7. Ліпкан В.А., Капінус Л.І. Доступ до інформації з обмеженим доступом: Проблеми вироблення уніфікованих дефініцій. Науково-практичний юридичний журнал «Публічне право». 2013. № 4. C. 45-53.

8. Податковий кодекс України : Закон України від 02.12.2010 № 2755-VI / Верховна Рада України. URL : https://zakon.rada.gov.ua/laws/show/2755-17\#Text (дата звернення: 08.11.2021).

9. Про доступ до публічної інформації : Закон України від 13.01.2011 № 2939-VI / Верховна Рада України. URL : https://zakon.rada.gov.ua/laws/show/2939-17\#Text (дата звернення: 08.11.2021).

10. Про інформацію : Закон України від 02.10.1992 № 2657-XII / Верховна Рада України. URL : https://zakon.rada.gov.ua/laws/show/2657-12\#Text (дата звернення: 08.11.2021).

11. Про затвердження положень про Державну податкову службу України та Державну митну службу України : Постанова Кабінету Міністрів України від 06.03.2019 № 227 / Кабінет Міністрів України. URL : https://zakon.rada.gov.ua/laws/show/227-2019-\%D0\%BF\#n15 (дата звернення: 08.11.2021).

12. Про практику застосування адміністративними судами законодавства про доступ до публічної інформації : Постанова Пленуму Вищого адміністративного суду України від 29.09.2016 № 10 / Вищийадміністративний суд України.URL:https://zakon.rada.gov.ua/laws/show/v0010760-16\#Text (дата звернення: 08.11.2021).

13. Проць I.М. Податкова таємниця в законодавстві зарубіжних країн. Електронне наукове видання «Порівняльно-аналітичне право». 2020. № 4. С. 539-545.

14. Твердохліб О.С. Доступ до публічної інформації в Україні: проблеми застосування «трискладового тесту». Публічне управління та митне адміністрування. № 1 (16). 2017. С. 62-69.

\section{References:}

1. Avdieieva H.K. (2020). Problemy vykorystannia elektronnykh dokaziv u protydii pravoporushenniam u podatkovii sferi [Problems of using electronic evidence in counteracting offenses in the tax sphere]. Protydiia minimizatsii splaty podatkiv: svitovyi dosvid ta praktyka Ukrainy : zbirnyk materialiv III Naukovo-praktychnoho kruhloho stolu, m. Irpin, 15 travnia 2020 r. Irpin : NDI fiskalnoi polityky, 2020. S. 84-86 [in Ukrainian].

2. Holovenko R., Kotliar D., Slyzkonis D. (2014). Dostup do publichnoi informatsii : posibnyk iz zastosuvannia «tryskladovoho testu». [Access to public information: a guide to the use of «three-part test»)]. Kyiv : TsPSA, 2014. 152 s. [in Ukrainian].

3. Yesimov S., Kovaliv M., Skrynkovskyi R. (2018). Pravovi rezhymy sluzhbovoi informatsii v Ukraini. [Legal regimes of official information in Ukraine]. Traektoriâ Nauki = Path of Science. 2018. Vol. 4. № 4, S. 7001-7012 [in Ukrainian].

4. Zbinskyi Ye.F. (2016). Pravovyi rezhym podatkovoi taiemnytsi v Ukraini [Legal regime of tax secrecy in Ukraine] : avtoref. dys. ... kand. yuryd. nauk : 12.00.07. Zaporizhzhia, 22 s. [in Ukrainian]. 
5. Kushnir I.P. (2019). Pravovyi rezhym informatsii z obmezhenym dostupom u diialnosti Derzhavnoi prykordonnoi sluzhby Ukrainy [Legal regime of information with limited access in the activity of the State Border Guard Service of Ukraine]. Pravo ta derzhavne upravlinnia. № 3 (36), S. 180-185 [in Ukrainian].

6. Latsyba M.V., Khmara O.S., Andrusiv V.V. (2012). Metodychni rekomendatsii shchodo praktychnoho vprovadzhennia Zakonu Ukrainy «Pro dostup do publichnoi informatsii» [Methodical recommendations on practical implementation of the Law of Ukraine «On access to public information»]. Ukr. nezalezh. tsentr polit. doslidzh. Kyiv : Ahentstvo «Ukraina», 164 s. [in Ukrainian].

7. Lipkan V.A., Kapinus L.I. (2013). Dostup do informatsii z obmezhenym dostupom: Problemy vyroblennia unifikovanykh definitsii [Access to information with limited access: Problems of developing unified definitions]. Naukovo-praktychnyi yurydychnyi zhurnal «Publichne pravo». № 4, S. 45-53 [in Ukrainian].

8. Podatkovyi kodeks Ukrainy : Zakon Ukrainy vid 02.12.2010 № 2755-VI (2010) [Tax Code of Ukraine: Law of Ukraine of 02.12.2010 № 2755] / Verkhovna Rada Ukrainy. URL : https://zakon.rada.gov.ua/ laws/show/2755-17\#Text (appeal date: 08.11.2021) [in Ukrainian].

9. Pro dostup do publichnoi informatsii : Zakon Ukrainy vid 13.01.2011 № 2939-VI (2011) [On access to public information: Law of Ukraine of 13.01.2011 № 2939-VI] / Verkhovna Rada Ukrainy. URL : https://zakon.rada.gov.ua/laws/show/2939-17\#Text (appeal date: 08.11.2021) [in Ukrainian].

10. Pro informatsiiu : Zakon Ukrainy vid 02.10.1992 № 2657-XII (1992) [About information: Law of Ukraine 02.10.1992 № 2657-XII] / Verkhovna Rada Ukrainy. URL : https://zakon.rada.gov.ua/laws/ show/2657-12\#Text (appeal date: 08.11.2021) [in Ukrainian].

11. Pro zatverdzhennia polozhen pro Derzhavnu podatkovu sluzhbu Ukrainy ta Derzhavnu mytnu sluzhbu Ukrainy : Postanova Kabinetu Ministriv Ukrainy vid 06.03.2019 № 227 (2019) [On approval of the provisions on the State Tax Service of Ukraine and the State Customs Service of Ukraine: Resolution of the Cabinet of Ministers of Ukraine of 06.03.2019 № 227] / Kabinet Ministriv Ukrainy. URL : https://zakon.rada.gov.ua/laws/show/227-2019-\%D0\%BF\#n15 (appeal date: 08.11.2021) [in Ukrainian].

12. Pro praktyku zastosuvannia administratyvnymy sudamy zakonodavstva pro dostup do publichnoi informatsii : Postanova Plenumu Vyshchoho administratyvnoho sudu Ukrainy vid 29.09.2016 № 10 (2016) [On the practice of application by administrative courts of legislation on access to public information: Resolution of the Plenum of the Supreme Administrative Court of Ukraine of 29.09.2016 № 10] / Vyshchyi administratyvnyi sud Ukrainy. URL : https://zakon.rada.gov.ua/laws/ show/v0010760-16\#Text (appeal date: 08.11.2021) [in Ukrainian].

13. Prots I.M. (2020). Podatkova taiemnytsia v zakonodavstvi zarubizhnykh krain [Tax secrecy in the legislation of foreign countries]. Elektronne naukove vydannia «Porivnialno-analitychne pravo». № 4, S. 539-545 [in Ukrainian].

14. Tverdokhlib O.S. (2017). Dostup do publichnoi informatsii v Ukraini: problemy zastosuvannia «tryskladovoho testu» [Access to public information in Ukraine: problems of application of the «three-component test»]. Publichne upravlinnia ta mytne administruvannia. № 1 (16), S. 62-69 [in Ukrainian].

\section{Zytsyk S. H. Legal regime of information on taxpayers in Ukraine}

The article is devoted to the legal regulation of the procedure for providing tax authorities with information on taxpayers for third parties, obtained as a result of the activities of these authorities. The procedure for the transition of tax authorities to electronic document management has been studied. Electronic information about the taxpayer is used as evidence in criminal and administrative cases, as well as in the implementation of tax procedures related to the establishment and approval of tax liabilities. The question of the admissibility of the use of information databases on taxpayers as an evidence base in administrative procedures and litigation is considered. It is pointed out that it is inadmissible for the tax authorities to use dynamic information about the taxpayer from sites that are periodically updated without additional confirmation of this information. It is proposed to specify the list of information about taxpayers (honest), which is prohibited to distribute without their consent-information that is confidential to others and is not public information. The types of «secrets» defined by the legislation in various spheres of public activity which essence consists in non-disclosure of the information received by officials at implementation of their professional activity are investigated. The necessity of making changes to the Tax Code of Ukraine in terms of defining the term "tax secrecy» is substantiated; imposing an obligation to maintain tax 
secrecy on tax authorities (instead of the currently defined right of taxpayers not to disclose information about them); exclusion from the list of confidential tax information that is open to third parties. Given the significant public interest and public importance of information about persons who cause damage to the financial security of the state, it is proposed to include in the socially necessary information information about taxpayers and beneficiaries (politicians, statesmen) who by their active illegal actions hinder public funds in the form of taxes and meeting.

Key words: tax secrecy, tax information, legal regime of information about taxpayers. 
УДК: 349.412(477)

DOI https://doi.org/10.31392/NPU-nc.series18.2021.36.07

Калетнік Г. М., Опольська Н. М.

\section{НАБУТТЯ ПРАВА ВЛАСНОСТІ НА ЗЕМЕЛЬНІ ДІЛЯНКИ СІЛЬСЬКОГОСПОДАРСЬКОГО ПРИЗНАЧЕННЯ В УКРАЇНІ В РОЗРІЗІ ПРЕЦЕДЕНТНОЇ ПРАКТИКИ СВРОПЕЙСЫКОГО СУДУ ІЗ ПРАВ ЛЮДИНИ}

У статті проведено аналіз відповідності обмежень щзоо запровадження обігу земель сільськогосподарського призначення в Україні «триступеневому тесту», який використовує Свропейський суд із прав людини у справах про визнання правомірності втручання держави у конкретне право. Встановлено, щзо при визнанні правомірними обмежень права на мирне володіння майном, щэо накладаються органами державної влади, Європейський суд із прав людини використовує «триступеневий тест»: чи є обмеження законним, чи має обмеження на меті суспільний інтерес, чи є обмеження пропориійним та чи переслідує легітимну мету.

Визначено поняття «суспільного інтересу» щодо запровадження обігу земель сільськогосподарського призначення, який полягає у забезпеченні ефективного користування землею та уникненні надмірної концентрачії земельної власності, зокрема, в руках економічних гравиів, не залучених до місиевого сільського життя та фермерства.

Доведено, шо умови, на яких запроваджується обіг земель сільськогосподарського призначення в Украӥні, не відповідають «триступеневому тесту» прецедентної практики Європейського суду із прав людини.

Щодо першого критерію доведено, щзо при зверненні до ССПЛ щзодо обмеження фізичних іюридичних осіб у праві набуття права власності на земельні ділянки сільськогосподарського призначення є достатньо правових підстав для визнання запроваджених обмежень такими, що не відповідають критеріям законності у розрізі преиедентної практики ЄСПЛ.

Щодо другого критерію визначено, щзо обмеження не забезпечують ефективного користування землею сільськогосподарського призначення та уникнення надмірної концентрації земельної власності, в руках економічних гравців, не залучених до місцевого сільського життя та фермерства.

Щодо третього критерію, чи є обмеження пропориійним та чи переслідує «легітимну мету», доведено, щьо закон надає невиправдану перевагу певним суб'єктам права, не відповідає принципу правової визначеності, що ставить під сумнів і його легітимну мету.

Ключові слова: обіг земель сільськогосподарського призначення, право на мирне володіння майном, право власності на землі сільськогосподарського призначення.

\section{Постановка проблеми.}

Однією з гарантій реалізації права власності на земельні ділянки сільськогосподарського призначення в Україні є стаття 1 Протоколу до Конвенції про захист прав людини й основоположних свобод (далі Конвенція), яка передбачає захист власності. Кожна фізична або юридична особа має право мирно володіти своїм майном. Ніхто не може бути позбавлений своєї власності інакше як в інтересах суспільства і на умовах, передбачених законом і загальними принципами міжнародного права. Проте попередні положення жодним чином не обмежують право держави вводити в дію такі закони, які вона вважає за необхідне, щоби здійснювати контроль за користуванням майном відповідно до загальних інтересів або для забезпечення сплати податків чи інших зборів або штрафів [1, ст. 1].

Пленум Вищого спеціалізованого суду України зазначає, що гарантування кожному права на справедливий суд та реалізація права людини на судовий захист повинні здійснюватися 3 урахуванням норм Конвенції [2], а також практики Європейського суду з прав людини (далі ЄСПЛ), які відповідно до статті 17 Закону України «Про виконання рішень та застосування практики Європейського суду з прав людини» від 23 лютого 2006 року застосовуються судами під час розгляду справ як джерела права [3].

Предметом регулювання статті 1 Протоколу до Конвенції є втручання держави у право на мирне володіння майном. У розрізі прецедентної практики ЄСПЛ мораторій на обіг земель 
сількогосподарського призначення в Україні був порушенням статті 1 Протоколу до Конвенції, яка гарантує право на повагу до власності. У справі «Зеленчук та Цицюра проти України» ЄСПЛ вказав, що свобода розсуду, якою користуються національні органи влади в Україні, не може охоплювати такі надзвичайні заходи, як абсолютна заборона відчуження землі. У жодній іншій державі не було такої абсолютної заборони, лише встановлювалися певні умови щодо продажу та перепродажу [4].

\section{Аналіз останніх досліджень і публікацій.}

Науково-теоретичним підгрунтям цієї статті стали концептуальні підходи до питання обігу земель сільськогосподарського призначення таких українських та зарубіжних учених, як Д. Гом’єн [5], В. Русан, Л. Жураковська [6], Г. Калетнік [7], Т. Оверковська [8].

Постановка завдання. Метою статті $€$ аналіз відповідності обмежень щодо запровадження обігу земель сільськогосподарського призначення в Україні «триступеневому тесту», який використовує ЄСПЛ у справах про визнання правомірності втручання держави у конкретне право.

\section{Виклад основного матеріалу дослідження.}

Із запровадженням обігу земель сількогосподарського призначення доцільно проаналізувати набуття права власності в Україні відповідно до критеріїв правомірності втручання держави у мирне володіня майном у розрізі практики ЄСПЛ. Рішення ЄСПЛ розкривають принципові підходи щодо розуміння обмеження права власності. У цьому контексті дослідження практики ЄСПЛ у сфері права на мирне володіння майном набуває особливої актуальності.

У практиці ЄСПЛ, зокрема у рішеннях ЄСПЛ у справах «Джеймс та інші проти Сполученого Королівства» від 21 лютого 1986 року [9], «Щокін проти України» від 14 жовтня 2010 року [10], «Сєрков проти України» від 07 липня 2011 року [11], «Колишній король Греції та інші проти Греції» від 23 листопада 2000 року [12], «Трегубенко проти України» від 2 листопада 2004 року [13] та інші напрацьовано три критерії, які слід оцінювати на предмет сумісності заходу втручання у право особи на мирне володіння майном із гарантіями статті 1 Протоколу до Конвенції.

При визнанні правомірними обмежень права на мирне володіння майном, що накладаються органами державної влади, ЄСПЛ використовує «триступеневий тест»:

\section{1. Чи є обмеження законним?}

2. Чи має обмеження на меті суспільний інтерес?

3. Чи є обмеження пропориійним та чи переслідує легітимну мету?

Обіг земель сільськогосподарського призначення в усіх країнах, де існує такий ринок, підлягає певним законодавчим обмеженням. Проаналізуємо обмеження обігу земель сільськогосподарського призначення, які запроваджуються в Україні, на «триступеневий тест» правомірності таких обмежень відповідно до практики ЄСПЛ.

Перший критерій: чи є обмеження законним?

У справі «Зеленчук та Цицюра проти України» ЄСПЛ оприлюднив своє рішення 22 травня 2018 року. Суд визнав земельний мораторій порушенням права людини розпоряджатися своєю власністю, гарантованого статтею 1 Протоколу до Конвенції, а також статтею 41 Конституції України. У рішенні Суд постановив, що уряд повинен вжити законодавчі заходи для забезпечення необхідного справедливого балансу для власників земельних ділянок сільськогосподарського призначення, зобов'язавши Україну виплатити кожному із заявників по 3000 євро та додатково компенсацію судових витрат [4].

Із прийняттям цього рішення в нашій країні з'явилася надія, що після 20-річного мораторію на відчуження земель сількогосподарського призначення власники земель нарешті зможуть вільно розпоряджатися своєю власністю, а фермери, які обробляють землю, отримають можливість купувати іiї та господарювати на своїй землі. Вважаємо, що для нормального функціонування ринку земель в Україні держава повинна забезпечити прозорість такого ринку та права як потенційних продавців, так і покупців земель сільськогосподарського призначення.

Принцип законності у прецедентній практиці ЄСПЛ має широке тлумачення. Однак перша вимога - це наявність відповідної норми у національному законі. У разі іiї відсутності можна 
констатувати порушення вже на цьому етапі, без подальших перевірок. Як зазначає Д. Гом'єн, поняття «законність» набуває в практиці Суду автономного тлумачення, а чинний національний закон ураховується лише як вихідний пункт, текст та застосування якого ЄСПЛ перевіряє у світлі більш широких критеріїв законності [5, с. 38].

На формальне дотримання першої вимоги, тобто наявності норми закону при запровадженні обігу земель, 31 березня 2020 Верховна Рада України прийняла Закон України № 552-IX «Про внесення змін до деяких законодавчих актів України щодо умов обігу земель сільськогосподарського призначення» [14]. 28 квітня 2021 року було прийнято Закон України № 1423-IX «Про внесення змін до Земельного кодексу України та інших законодавчих актів щодо удосконалення системи управління та дерегуляції у сфері земельних відносин» [15].

Проаналізувавши вказані закони, слід відзначити, що пропоновна модель ринку земель сількогосподарського призначення в Україні має багато ризиків, колізій та непропорційних обмежнь права на мирне володіння майном у розумінні статті 1 Протоколу до Конвенції. Згідно 3 практикою ЄСПЛ втручання держави у право на мирне володіння майном $є$ законним, якщо здійснюється на підставі закону, що має бути доступним для зацікавлених осіб, чітким і передбачуваним із питань застосування та наслідків дії його норм [4].

Нині слід відзначити, що відповідність прийнятих законів Конституції України поставлена під сумнів. Так, у Конституційному Суді України розглядається справа за конституційними поданнями 48 та 53 народних депутатів України щодо відповідності Конституції України Закону України «Про внесення змін до деяких законодавчих актів України щодо умов обігу земель сільськогосподарського призначення» від 31 березня 2020 року № 552-IX, які об’єднано в одне конституційне провадження [16].

Серед спірних аргументів, на наш погляд, слід вказати думку суб'єктів подання, що питання власності на землю має вирішуватися на референдумі. Адже стаття 13 Коституції України вказує, що земля є об'єктом права власності українського народу, від імені якого права власника здійснюють органи державної влади та органи місцевого самоврядування [17].

Окремого дослідження потребує питання, яке викладено у конституційному поданні щодо конституційності положення Закону № 552-IX про викуп земель фермерськими господарствами, що попередньо надавалися на праві постійного користування для заснування фермерського господарства. Погоджуючись із недосконалістю врегулювання цього питання, слід зауважити, що 15 квітня 2021 року було зареєстровано Проект Закону № 5385 «Про внесення змін до Земельного кодексу України та інших законодавчих актів щодо скасування інституту права постійного користування земельними ділянками» 3 метою внесення змін до Земельного кодексу України, в частині надання права фізичним та юридичним особам приватного права переоформити право постійного користування на право оренди строком на 50 років, а також право викупу земельної ділянки із 30-річним розстроченням платежу [18]. Також вказаним Проектом Закону пропонується трансформація права постійного користування землею у сучасні правові титули, а саме право оперативного управління та право господарського відання.

Вважаємо, що прийняття парламентом вказаного Проекту Закону за основу може спричинити порушення прав ЗВО на користування земельними ділянками. Проект не містить норми, яка надає ЗВО право отримувати земельні ділянки у користування на підставі права оперативного управління чи права господарського відання.

Варто погодитись із позицією суб'єктів конституційного подання у тому, що закон містить неврегульованості, суперечності з іншими положеннями законодавства, надає невиправдану перевагу певним суб'єктам права, не відповідає принципу правової визначеності, що ставить під сумнів і його легітимну мету. У конституційному поданні зазначається, що нормативним актом закладається нерівність перед законом суб'єктів права власності та надається невиправдана перевага банкам на земельному ринку [16, с.5]. Ми погоджуємось із тим, що банки порівняно з іншими юридичними особами, в тому числі орендарями земельних ділянок, які обмежені до 2024 року в можливості набуття права власності на землі сільськогосподарського призначення, мають невиправдану перевагу. Усі юридичні особи, крім банків, не мають права 
до 2024 року набувати право власності на земельні ділянки сільськогосподарського призначення, що вказує на непропорційність запроваджених обмежень.

Слід відзначити, що відповідно до законів № 552-IX та № 1423-IX на банки не поширюється й обмеження «не більше ніж 100 га (з 2024 року - 10 тис. га) в одні руки» $[14,15]$. Їм надається право володіти землями сільськогосподарського призначення за умови, що їх стягнули як заставу за кредитом, і за два роки банки мають продати заставну землю на електронних торгах. На наш погляд, у такий спосіб на ринок землі вводиться посередник, узаконюються тіньові схеми та можливість створення умов для концентрації земель сільськогосподарського призначення в певних руках.

Крім того, слід відзначити, що сьогодні в Україні чисельність банків з іноземним капіталом зростає. Згідно із законодавством, на них не поширюються запроваджені обмеження, тому що вони є не покупцями, а стягують землі сільськогосподарського призначення як заставні за кредитами. Виникає питання про дієвість законодавчого обмеження щодо набуття у власність цих земель іноземцями, якщо такі банки можуть набувати права власності на землі сільськогосподарського призначеня строком на 2 роки. 3 метою викупу земель сільськогосподарського призначення фермери будуть шукати можливості отримати кредит. Хто тоді стане власником земель у випадку неврожаю, збитковості чи банкрутства фермера, який взяв кредит під заставу землі?

Розв'язати проблему викупу земель сільськогосподарського призначення, які є підзаставними, а також забезпечити отримання кредиту під помірні відсотки потенційними покупцями таких земель можна було б, повернувшись до концептуальних засад створення Державного земельного (іпотечного) банку в Україні, які були розроблені в законопроекті «Про ринок земель» від 18.07.2011 р. № 9001 [19]. В той час створення Держзембанку викликало гостру критику з боку іноземного бізнесу, національних агрохолдингів і банківського сектору. Незважаючи на те, що у 2012 році в Україні було створено публічне акціонерне товариство «Державний земельний банк» за рахунок коштів державного бюджету, у 2014 році банк було розпродано.

Повертаючись до аналізу конституційного подання [16], слід зауважити, що сама по собі підстава суперечності з іншими положеннями законодавства як можливість визнання Закону № 552-IX неконституційним не відповідає компетенції Конституційного Суду України (далі КСУ). Адже під час розгляду такого роду справ КСУ обмежується лише питанням конституційності законів або їх окремих положень [20, ст. 8]. Відповідно, КСУ не може розглядати колізії законів, а повноваження заповнення прогалин у законодавстві України має виключно парламент.

Отже, питання відповідності прийнятих нормативно-правових актів принципу законності як одного з керівних принципів у практиці ЄСПЛ потребує подальшого дослідження з урахуванням рішення КСУ щодо конституційності Закону № 552-IX. При зверненні до ЄСПЛ юридичних та фізичних осіб щодо обмеження їх у праві набуття права власності на земельні ділянки сільськогосподарського призначення $\epsilon$ достатньо правових підстав для визнання запроваджених обмежень такими, що не відповідають критеріям законності у розрізі прецедентної практики ЄСПЛ.

Другий критерій:чи має обмеження на меті суспільний інтерес?

Беручи до уваги потребу у створенні потужних стимулів для розвитку економіки, а також розуміючи важливість створення умов для формування потужного середнього класу у сільській місцевості, скасування мораторію на продаж земель сільськогосподарського призначення як такого відповідає суспільним інтересам. Однак, розкриваючи цей критерій, доцільно проаналізувати інтереси, які забезпечуються тими окремими обмеженнями, що запроваджуються змінами до законів.

Саме національні органи влади мають здійснювати первісну оцінку наявності проблеми, що становить суспільний інтерес, вирішення якої вимагало б таких заходів. Поняття «суспільний інтерес» у практиці ЄСПЛ має широке тлумачення, яке викладено у рішенні від 23 листопада 2000 року в справі «Колишній король Греції та інші проти Греції» [12]. Крім того, ССПЛ також 
визнає, що правильне застосування законодавства, безперечно, становить суспільний інтерес рішення ССПЛ від 02 листопада 2004 року в справі «Трегубенко проти України» [13].

Аналіз рішення ЄСПЛ «Зеленчук та Цицюра проти України» [4] дає можливість визначити поняття «суспільного інтересу» щодо запровадження обігу земель сільськогосподарського призначення, який полягає у:

- забезпеченні ефективного користування землею для сільськогосподарського призначення;

- уникненні надмірної концентрації земельної власності, зокрема, «в руках економічних гравців, не залучених до місцевого сільського життя та фермерства». Пункт 127 Рішення у справі «Зеленчук та Цицюра проти України» містить узагальнення європейської мети регулювання ринку землі, що полягає у формуванні цивілізованого та ефективного ринку, в інтересах народів цих держав [4].

Під час аналізу відповідності суспільному інтересу тих умов, на яких запроваджується досліджуваний ринок, варто наголосити на тому, що у змінах до законодавства відсутні кваліфікаційні вимоги до покупців земель сільськогосподарського призначення.

Стаття 130 «Покупці земель сільськогосподарського призначення» Земельного кодексу України в редакції закону, який діяв до 28 травня 2021 року, встановлювала таке:

1. Покупцями земельних ділянок сільськогосподарського призначення для ведення товарного сільськогосподарського виробництва можуть бути: а) громадяни України, які мають сільськогосподарську освіту або досвід роботи у сільському господарстві чи займаються веденням товарного сільськогосподарського виробництва; б) юридичні особи України, установчими документами яких передбачено ведення сільськогосподарського виробництва.

2. Переважне право купівлі земельних ділянок сільськогосподарського призначення мають громадяни України, які постійно проживають на території відповідної місцевої ради, де здійснюється продаж земельної ділянки, а також відповідні органи місцевого самоврядування [21].

328 травня 2021 року статтю 130 Земельного кодексу України викладено у новій редакції. Набувати право власності на земельні ділянки сільськогосподарського призначення можуть: а) громадяни України; б) юридичні особи України, створені і зареєстровані за законодавством України, учасниками (акціонерами, членами) яких є лише громадяни України та/або держава, та/або територіальні громади; в) територіальні громади; г) держава [22].

Аналізуючи цю норму, варто погодитись із думкою, яку висвітлюють В. Русан, Л. Жураковська, що під час запровадження ринку землі необхідним є збереження принаймні таких вимог до земленабувачів:

- до фізичних осіб: наявність сільськогосподарської освіти, досвід роботи в сільському господарстві, а також наявність умови, що місцем проживання для громадян повинна бути територія відповідної місцевої ради, де розташована земельна ділянка;

- до юридичних осіб: установчими документами яких передбачено ведення товарного сільськогосподарського виробництва і у яких валовий дохід, отриманий від операцій з реалізації сільськогосподарської продукції власного виробництва та продуктів її переробки, за наявності сільськогосподарських угідь та/або поголів'я сільськогосподарських тварин у власності, користуванні, в тому числі на умовах оренди, за попередні п'ять звітних (податкових) років перевищує 75\% загальної суми валового доходу, а також місцем реєстрації є територія відповідної місцевої ради, де розташована земельна ділянка [6].

Ця умова, на наш погляд, є визначальною для забезпечення реалізації суспільного інтересу, соціального розвитку села та територіальних громад. Оскільки, відповідно до реформи децентралізації, розвиток сільських населених пунктів повністю залежить від платоспроможності бюджетів ОТГ, що наповнюються за рахунок податків фізичних та юридичних осіб, які зереєстровані в ОТГ.

Отже, аналізуючи, чи мають на меті обмеження, які накладаються на фізичних та юридичних осіб при запровадженні обігу земель сільськогосподарського призначення в Україні, суспільний інтерес, можна відзначити, що вони не забезпечують ефективного користування землею сільськогосподарського призначення та створюють умови для надмірної концентрації земельної власності в руках економічних гравців, не залучених до місцевого сільського життя та фермерства. 
Третій критерій: чи є обмеження пропориійним та чи переслідує легітимну мету?

Втручання держави в право особи на мирне володіння своїм майном повинно здійснюватися 3 дотриманням принципу пропорційності, тобто справедливої рівноваги, балансу між інтересами держави, суспільства, які пов'язані із втручанням та інтересами особи.

Як уже зазначалося, дотримання принципу пропорційності відсутнє щодо набуття права на викуп земель сільськогосподарського призначення, адже ці обмеження стосуються юридичних осіб (орендарів), проте не розповсюджуються на банки. Банки зможуть набувати право власності на земельні ділянки сільськогосподарського призначення шляхом стягнення на них як на предмет застави. На наш погляд, це суперечить принципу пропорційності, адже банки стануть тими економічними гравцями, які не залучені до місцевого сільського життя та фермерства.

Відповідно до змін у законодавстві, переважного права купівлі земельних ділянок сільськогосподарського призначення набуває орендар, який згідно із законами № 552-IX та № 1423-IX $[14,15]$ може мати у власності орендовану земельну ділянку, якщо інше не передбачено законом. Проте до 1 січня 2024 року жодна юридична особа не зможе купити або іншим способом набути у власність раніше «підмораторну» земельну ділянку.

Отже, наявність у орендаря - юридичної особи переважного права на купівлю земельної ділянки сільськогосподарського призначення не може бути реалізовано останнім, оскільки в силу законів $[14,15,22]$ юридичній особі заборонено до 2024 року купувати земельні ділянки сільскогосподарського призначення. Така колізія в земельному законодастві стане причиною для численних судових спорів, у тому числі в ССПЛ, щодо обмеження права на мирне володіння майном в розумінні статті 1 Протоколу до Конвенції [1].

\section{Висновки.}

Підводячи підсумок аналізу умов, на яких запроваджується обіг земель сільськогосподарського призначення в Україні, у розрізі «триступеневого тесту» прецедентної практики ЄСПЛ, слід відзначити:

- щодо першого критерію (чи є обмеження, які накладаються із запровадженням ринку землі законними?) - оцінку має надати КСУ. Однак при зверненні до ЄСПЛ щодо обмеження фізичних і юридичних осіб у праві набуття права власності на земельні ділянки сільськогосподарського призначення є достатньо правових підстав для визнання запроваджених обмежень такими, що не відповідають критеріям законності у розрізі прецедентної практики ЄСПЛ;

- щодо другого критерію (чи мають обмеження на меті суспільний інтерес?) потрібно відзначити, що обмеження не забезпечують ефективного користування землею сільськогосподарського призначення та уникнення надмірної концентрації земельної власності в руках економічних гравців, не залучених до місцевого сільського життя та фермерства;

- щодо третього критерію (чи є обмеження пропорційними та чи переслідують легітимну мету?) слід відзначити, що закон надає невиправдану перевагу певним суб'єктам права та не відповідає принципу правової визначеності, що ставить під сумнів і його легітимну мету.

\section{Використана література:}

1. Протокол до Конвенції про захист прав людини і основоположних свобод від 17.07.1997 p. URL: https://zakon.rada.gov.ua/laws/show/994_535\#Text (дата звернення: 09.07.2021).

2. Конвенція про захист прав і основоположних свобод людини від 04.11.1950 p. URL: http://zakon4.rada.gov.ua/laws/show/995_004/print1389988659002889 (дата звернення: 09.07.2021).

3. Про деякі питання юрисдикції загальних судів та визначення підсудності цивільних справ № 3 від 01.03.2013. URL : https://zakon.rada.gov.ua/laws/show/v0003740-13\#Text.

4. European Court of Human Rights. Case of Zelenchuk and Tsytsyura v. Ukraine (14.09.2018). URL: https://zakon.rada.gov.ua/laws/show/974_c79\#Text (дата звернення 07.05.2021).

5. Гом’єн Д. Короткий путівник Європейською конвенцією з прав людини. Київ: «Фенікс», 2006. $92 \mathrm{c}$.

6. Русан В.М., Жураковська Л.А. Щодо Закону України «Про внесення змін до деяких законодавчих актів України щодо обігу земель сільськогосподарського призначення». Національний інститут стратегічних досліджень. URL :https:/niss.gov.ua/sites/default/files/2020-04/zakon-prozemlyu.pdf (дата звернення: 19.07.2021). 
7. Калетнік Г.М., Козловський С.В., Ціхановська В.М. Перспективи розвитку земельних відносин та ринку землі в Україні. Агросвіт. 2012. № 12. С. 2-6.

8. Оверковська Т.К. Моніторинг земель України: правові аспекти. Юридичний вісник. Повітряне і космічне право. 2015. № 1. C. 125-128. URL: http://nbuv.gov.ua/UJRN/Npnau 2015125 (дата звернення: 19.07.2021).

9. Рішення Європейського суду з прав людини в справі «Джеймс та інші проти Сполученого Королівства» (21.02.1986) URL: https://zakon.rada.gov.ua/laws/show/980_180\#Text (дата звернення 15.06.2021).

10. Рішення Європейського суду з прав людини в справі «Щокін проти України» (14.10.2010). URL: https://zakon.rada.gov.ua/laws/show/974_858\#Tеxt (дата звернення 15.07.2021).

11. Рішення Європейського суду з прав людини в справі «Сєрков проти України» (07.082011). URL: https://ips.ligazakon.net/document/soo00264 (дата звернення 15.07.2021).

12. Рішення Європейського суду з прав людини в справі «Колишній король Греції та інші проти Греції» (23.10.2000). URL: https://zakon.rada.gov.ua/laws/show/980 007\#Text (дата звернення 15.07.2021).

13. Рішення Європейського суду з прав людини в справі «Трегубенко проти України» «02.10.2004) URL: https://zakon.rada.gov.ua/laws/show/980 355\#Text (дата звернення 15.07.2021).

14. Про внесення змін до деяких законодавчйх актів України щодо умов обігу земель сільськогосподарського призначення: Закон України від 31 березня 2020 року № 552-IX. URL : https://zakon.rada.gov.ua (дата звернення 14.07.2021).

15. Про внесення змін до Земельного кодексу України та інших законодавчих актів щодо удосконалення системи управління та дерегуляції у сфері земельних відносин: Закон України від 28 квітня 2021 року № 1423-IX. URL: https://zakon.rada.gov.ua (дата звернення 14.07.2021).

16. Конституційне подання щодо відповідності Конституції України (конституційності) Закону України «Про внесення змін до деяких законодавчих актів України щодо умов обігу земель сільськогосподарського призначення» від 31 березня 2020 року. Офіційний сайт Конституційного Суду України. URL: https://ccu.gov.ua/sites/default/files/3_186_2020_0.pdf (дата звернення 14.07.2021).

17. Конституція України: Закон від 28.06.1996 № 254к/96-BP URL: http://zakon3.rada.gov.ua/laws/ show/62/95-\%D0\%B2\%D1\%80 (дата звернення: 19.06.2021).

18. Про внесення змін до Земельного кодексу України та інших законодавчих актів щодо скасування інституту права постійного користування земельними ділянками: проект закону України від 15.04.2021 p. № 5385. URL: http://w1.c1.rada.gov.ua/pls/zweb2/webproc4_1?pf3511=71680 (дата звернення: 18.06.2021).

19. Про ринок земель: проект закону України від 18.07.2011 p. № 9001. URL: http://search.ligazakon.ua/ 1_doc2.nsf/link1/JF6Y100A.html (дата звернення: 18.06.2021).

20. Про Конституційний Суд України: Закон України від 13.07.2017 p. № 2136-VIII. URL: https://zakon.rada.gov.ua/laws/show/2136-19\#Техt (дата звернення 20.05.2021 p.).

21. Земельний кодекс України: Закон України від 25.10.2001 р. № 2768-III. Відомості Верховної Ради України. 2002. № 3-4. Ст. 130.

22. Земельний кодекс України: Закон України від 25.10.2001 p. № 2768-III. URL: https://zakon.rada.gov.ua/laws/show/435-15 (дата звернення: 19.0.2021).

\section{References:}

1. Protokol do Konventsii pro zakhyst prav liudyny i osnovopolozhnykh svobod [Protocol to the Convention for the Protection of Human Rights and Fundamental Freedoms] (1997, August 17). Retrieved from: https://zakon.rada.gov.ua/laws/show/994_535\#Text [in Ukrainian].

2. Konventsiia pro zakhyst prav i osnovopolozhnykh svobod liudyny [Convention for the Protection of Human Rights and Fundamental Freedoms] (1950, November 11). Retrieved from: http://zakon4.rada. gov.ua/laws/show/995_004/print1389988659002889 [in Ukrainian].

3. Pro deiaki pytannia yurysdyktsii zahalnykh sudiv ta vyznachennia pidsudnosti tsyvilnykh sprav [On some issues of jurisdiction of general courts and determination of jurisdiction in civil cases] (2013, March 1). Retrieved from: https://zakon.rada.gov.ua/laws/show/v0003740-13\#Text [in Ukrainian].

4. European Court of Human Rights. Case of Zelenchuk and Tsytsyura v. Ukraine. (2018, September 14). Retrieved from: https://zakon.rada.gov.ua/laws/show/974_c79\#Text [in Ukrainian]. 
5. Homien, D. (2006). Korotkyi putivnyk Yevropeiskoiu konventsiieiu z prav liudyny [A short guide to the European Convention on Human Rights]. Kyiv: «Feniks», 92 p. [in Ukrainian].

6. Rusan, V.M., \& Zhurakovska, L.(2020). Shchodo Zakonu Ukrainy «Pro vnesennia zmin do deiakykh zakonodavchykh aktiv Ukrainy shchodo obihu zemel silskohospodarskoho pryznachennia» [Regarding the Law of Ukraine "On Amendments to Certain Legislative Acts of Ukraine Concerning the Circulation of Agricultural Lands"] Retrieved from: https://niss.gov.ua/sites/default/files/2020-04/ zakon-pro-zemlyu.pdf [in Ukrainian].

7. Kaletnik, G.M., Kozlovskyi, S.V., \& Tsikhanovska, V.M. (2012) Perspektyvy rozvytku zemelnykh vidnosyn ta rynku zemli v Ukraini [Prospects for the development of land relations and the land market in Ukraine.] Agrosvit - Agroworld, 12, 2-6 [in Ukrainian].

8. Overkovska, T.K. (2015). Monitorynh zemel Ukrainy: pravovi aspekty.[Monitoring of lands of Ukraine: legal aspects]. Yurydychnyi visnyk. Povitriane i kosmichne pravo-Legal Bulletin. Air and space law, 1, 125-128 [in Ukrainian].

9. Rishennia Yevropeiskoho sudu z prav liudyny v spravi «Dzheims ta inshi proty Spoluchenoho Korolivstva» [Judgment of the European Court of Human Rights in the case of James and Others v. The United Kingdom], (1986, February 21). Retrieved from: https://zakon.rada.gov.ua/laws/ show/980_180\#Text [in Ukrainian].

10. Rishennia Yevropeiskoho sudu z prav liudyny v spravi «Shchokin proty Ukrainy» [Judgment of the European Court of Human Rights in the case of Shchokin v. Ukraine], (2010, October 14). Retrieved from: https://zakon.rada.gov.ua/laws/show/974_858\#Text [in Ukrainian].

11. Rishennia Yevropeiskoho sudu z prav liudyny v spravi «Sierkov proty Ukrainy» [Judgment of the European Court of Human Rights in the case of Serkov v. Ukraine] (2011, August 7). Retrieved from: https://ips.ligazakon.net/document/soo00264 [in Ukrainian].

12. Rishennia Yevropeiskoho sudu z prav liudyny v spravi «Kolyshnii korol Hretsii ta inshi proty Hretsii» [Judgment of the European Court of Human Rights in the case of Former King of Greece and others v. Greece] (2000, October 23 ). Retrieved from: https://zakon.rada.gov.ua/laws/show/980_007\#Text [in Ukrainian].

13. Rishennia Yevropeiskoho sudu z prav liudyny v spravi «Trehubenko proty Ukrainy» [Judgment of the European Court of Human Rights in the case of Tregubenko v. Ukraine] (2004, October 2). Retrieved from: https://zakon.rada.gov.ua/laws/show/980_355\#Text[in Ukrainian].

14. Pro vnesennia zmin do deiakykh zakonodavchykh aktiv Ukrainy shchodo umov obihu zemel silskohospodarskoho pryznachennia: Zakon Ukrainy № 552-IX [On Amendments to Certain Legislative Acts of Ukraine Concerning the Conditions of Circulation of Agricultural Lands: Law of Ukraine] (2020, March 31). Retrieved from: https://zakon.rada.gov.ua [in Ukrainian].

15. Pro vnesennia zmin do Zemelnoho kodeksu Ukrainy ta inshykh zakonodavchykh aktiv shchodo udoskonalennia systemy upravlinnia ta derehuliatsii u sferi zemelnykh vidnosyn: Zakon Ukrainy № 1423-IX [On Amendments to the Land Code of Ukraine and Other Legislative Acts to Improve the Management and Deregulation System in the Sphere of Land Relations: Law of Ukraine № 1423-IX] (2021, April 28). Retrieved from: https://zakon.rada.gov.ua [in Ukrainian].

16. Konstytutsiine podannia shchodo vidpovidnosti Konstytutsii Ukrainy (konstytutsiinosti) Zakonu Ukrainy «Pro vnesennia zmin do deiakykh zakonodavchykh aktiv Ukrainy shchodo umov obihu zemel silskohospodarskoho pryznachennia» [Constitutional submission on the compliance of the Constitution of Ukraine (constitutionality) with the Law of Ukraine "On Amendments to Certain Legislative Acts of Ukraine Concerning the Conditions of Circulation of Agricultural Lands"] (2020, March 31). ccu.gov. ua. Retrieved from: https://ccu.gov.ua/sites/default/files/3_186_2020_0.pdf [in Ukrainian].

17. Konstytutsiia Ukrainy [The Constitution of Ukraine] (1996, June 28 ). Retrieved from: https://zakon.rada.gov.ua/laws/show/254\%D0\%BA/96-\%D0\%B2\%D1\%80 [in Ukrainian].

18. Pro vnesennia zmin do Zemelnoho kodeksu Ukrainy ta inshykh zakonodavchykh aktiv shchodo skasuvannia instytutu prava postiinoho korystuvannia zemelnymy diliankamy: proekt zakonu Ukrainy № 5385 [On Amendments to the Land Code of Ukraine and Other Legislative Acts Concerning the Abolition of the Institute of the Right to Permanent Use of Land Plots: Draft Law of Ukraine № 5385] (2021, April 15). Retrieved from: http://w1.c1.rada.gov.ua/pls/zweb2/webproc4_1?pf3511=71680 [in Ukrainian].

19. Pro rynok zemel: proekt zakonu Ukrainy № 9001[On the land market: Draft Law of Ukraine № 9001] (2011, August 18). Retrieved from: http://search.ligazakon.ua/1_doc2.nsf/link1/JF6Y100A.html [in Ukrainian]. 
20. Pro Konstytutsiinyi Sud Ukrainy: Zakon Ukrainy № 2136-VIII [On the Constitutional Court of Ukraine: Law of Ukraine № 2136 - VIII] (2017, August 13). Retrieved from: https: https://zakon.rada.gov.ua/laws/show/2136-19\#Text [in Ukrainian].

21. Zemelnyi kodeks Ukrainy No 2768-III [Land Code of Ukraine No 2768-III] (2001, October 25). Vidomosti Verkhovnoi Rady Ukrainy. 3-4, 130.

22. Zemelnyi kodeks Ukrainy No 2768-III. [Land Code of Ukraine No 2768-III.] (2001, October 25). Retrieved from: https://zakon.rada.gov.ua/laws/show/2768-14\#Text [in Ukrainian].

Kaletnik H. M., Opolska N. M., Acquisition of ownership out of agricultural land in Ukraine in the concern of case practice of the European Court of Human Rights

The article analyzes the compliance of restrictions on the introduction of agricultural land in Ukraine with the "three-stage test" used by the European Court of Human Rights in cases of recognition of the legitimacy of state intervention in a particular law. It has been established that in recognizing lawful restrictions on the right to intentional possession of property imposed by public authorities, the European Court of Human Rights uses the so-called three-step test: whether the restriction is legal, whether the restriction is for "public" interest and whether it pursues a "legitimate aim."

The concept of "public interest" in the introduction of agricultural land circulation, which is to ensure efficient use of agricultural land and avoid excessive concentration of land ownership, in particular, in the hands of economic players not involved in local rural life and farming.

It is proved that the conditions under which the circulation of agricultural land in Ukraine is introduced do not correspond to the three-stage test of the case law of the European Court of Human Rights.

It has been established that the CCI should provide an assessment of the first criterion of whether the restrictions imposed by the introduction of the land market are legal. It has been proved that, when appealing to the ECtHR, there are sufficient legal grounds for restricting the right of individuals and legal entities to acquire ownership of agricultural land plots that do not meet the legality criteria that do not meet the criteria of legality in terms of ECtHR case law.

Regarding the second criterion, whether the restriction is aimed at "public interest" - the restrictions do not ensure efficient use of agricultural land and avoid excessive concentration of land ownership in the hands of economic players not involved in local rural life and farming.

As to the third criterion, whether the restriction is proportionate and pursues a "legitimate aim", it has been shown that the law confers an unjustified advantage on certain subjects of law, does not comply with the principle of legal certainty, which calls into question its legitimate aim.

Key words: circulation of agricultural lands, the right to peaceful possession of property, the right of ownership of agricultural lands. 
УДК 343.97:343.91-053.6

DOI https://doi.org/10.31392/NPU-nc.series18.2021.36.08

Кончаковська В. В., Макарова О.В.

\section{ПРИЧИНИ ФОРМУВАННЯ КРИМІНОГЕННОЇ ПОВЕДІНКИ У НЕПОВНОЛІТНІХ}

У статті йдеться про визначальну роль сім'ї у вихованні дитини, профілактииі правового нігілізму і формуванні злочинної поведінки у підлітків. Розглянуто особливості сочіалізаиї дитини в сім'ї, а також фактори, які впливають на формування криміногенної поведінки неповнолітніх. Визначено основні недоліки сімейного виховання, проаналізовано статистику злочинності серед неповнолітніх за останні десять років.

Розглядається проблема сімейного неблагополуччя як основної причини, яка впливає на поведінку неповнолітнього. Крім того, виділено такі причини формування протиправної поведінки неповнолітніх, як: вплив найближчого оточення (друзі, школа, сусіди, знайомі), потреба в самоствердженні, надмірна опіка, вплив засобів масової інформащії, недоліки шкільного виховання, надлишок відеоігр та безконтрольне проведення часу за комп'ютером, смартфоном, у соиіальних мережах.

Важливим є вплив батьківського виховання та найближчого оточення на виховання дитини, іï сочіалізацію та формування правової спрямованості, з одного боку. 3 іншого - несприятлива обстановка в сім' $i$, негативні приклади переймаються дитиною, переносяться у свідому поведінку і сприймаються як норма.

Недостатня увага, надмірний контроль, недовіра до дитини з боку батьків відштовхує дітей від них, втрачається довіра, почуття безпеки, дружби, щзо в сукупності негативним чином відображається на вихованні та поведіниі зокрема.

На основі офіційної статистики констатовано, щзо за останні 10 років спостерігається зменшення чисельності зареєстрованих кримінальних правопорушень, вчинених неповнолітніми (зокрема, з 2012 р. до 2020 р. приблизно у 3,5 раза: із 14,5 тис. до 4 тис. зафіксованих випадків).

Запропонована модель поведінки вчителів у разі виявлення проблем у дитячому колективі з метою недопущення посягання на права, свободу, честь, гідність, законні інтереси неповнолітніх.

Ключові слова: неповнолітній, насильство, жорстокість, детермінанти злочинності, соціалізачія, злочин, причини.

Постановка проблеми. Проблема сімейного неблагополуччя, в тому числі як чинника злочинності неповнолітніх, сьогодні є об'єктом дослідження не лише кримінологів, а й психологів, педагогів, які в межах своєї професійної діяльності виконують виховну функцію, займаються профілактикою та корекцією аморальної і протиправної поведінки. Кримінологи, досліджуючи поведінку неповнолітніх, намагаються зрозуміти та виокремити причини й умови протиправної та аморальної поведінки. Зрозуміло, що, шукаючи відповіді щодо детермінант такої поведінки, цілком виправдано їх досліджувати у взаємозв'язку зі змінами та станом соціальної й економічної ситуації в державі. Адже саме ці чинники, поряд із політичними, впливають на добробут, дохід, розвиток усіх сфер суспільного життя й виховання дітей.

Динаміка злочинності в державі є мірилом правильно спланованої роботи на державному, спеціально-кримінологічному та індивідуальному рівнях. Говорячи про формування проявів протиправної поведінки, які в подальшому можуть призвести до вчинення злочинів неповнолітніми, серед основних факторів виділимо негативний вплив сімейного виховання, вплив найближчого оточення дитини (друзі, школа, сусіди, знайомі). Адже саме із сім'ї починається соціалізація дитини. Хоча не секрет, що соціалізація триває все життя, проте фундамент поведінки, розуміння моральних норм у суспільстві закладається саме в ранньому дитинстві.

Досить багато факторів можуть стати причиною формування соціально негативної поведінки, інколи злочинної. Поряд із сімейним і найближчим оточенням виділяють вплив засобів масової інформації, недоліки шкільного і побутового виховання. Тож підкреслимо, що несприятлива обстановка в сім’ї, негативні приклади переймаються дитиною, переносяться у свідому поведінку і сприймаються як норма. Адже дитина через недостатньо сформовану систему 
цінностей сприймає світ і бере приклад із найближчого оточення. Тому так важливо донести цінність людського життя, здоров'я, правила правомірної поведінки в соціумі, заборону посягання на честь і гідність та розуміння людини як найвищої соціальної цінності. Крім того, усвідомлення дитиною принципу рівності всіх, поваги до честі й гідності людини дозволить протидіяти такому, на жаль, нині розповсюдженому явищу, як жорстокість і насильство в дитячому колективі, в тому числі шкільному, а в подальшому житті зможе стати профілактикою сімейного насильства.

Перш ніж перейти безпосередньо до викладу матеріалу, відзначимо, що проблемами, пов'язаними $з$ дослідженням злочинності неповнолітніх, займаються досить багато науковців і практиків. Тема дійсно актуальна, тому інтерес до неї є зрозумілим. Серед науковців відзначимо роботи В.Д. Водніка, В. Голіна, С. Козлюк, Т. Слуцької.

Окремі аспекти досліджуваної проблематики розглядали у своїх дисертаційних роботах такі науковці, як Н.В. Кідіна («Кримінологічні засади індивідуалізації покарання неповнолітніх в Україні», Київ, 2021), О.М. Ситнік («Кримінологічна характеристика та запобігання втягненню неповнолітніх у злочинну діяльність в Україні», Харків, 2018).

Метою дослідження $є$ теоретичне узагальнення факторів, які впливають на формування злочинної поведінки серед неповнолітніх, із метою профілактики насильства і жорстокості в дитячому колективі.

Виклад основного матеріалу. Поглянемо на динаміку злочинності серед неповнолітніх: за останні 10 років можемо спостерігати зменшення чисельності зареєстрованих кримінальних правопорушень, вчинених неповнолітніми (2010 р. - 17342, 2011 р. - 17846, 2012 р. - 14238, 2013 p. $-8781,2014$ p. $-7467,2015$ p. $-7171,2016$ p. $-5230,2017$ p. $-5608,2018$ p. -4750 , 2019 р. - 4088, 2020 р. - 4019). Частка злочинів, що вчиняються дітьми, у структурі всієї злочинності в середньому становить до 8\%) [1, с. 1]. Тож можемо констатувати непогану роботу державних органів, фахових спеціалістів та, зокрема, сім'ї з роботи із профілактики злочинності серед неповнолітніх. Проте викликають занепокоєння зміни у структурі злочинності неповнолітніх, мотиви вчинення такими особами злочинів [2, с. 3].

Е. Дюркгейм писав: «Злочинність - нормальне явище, тому що суспільство без злочинності немислиме. Головне, щоб ії рівень не перевищував норми. Ненормально, коли цей рівень надто падає». Цілком із цим погоджуємося і не намагаємося розробити стратегію, щоби повністю позбутися вчинення досліджуваних видів злочинів [3, с. 149].

32012 р. до 2020 р. злочинність серед неповнолітніх зменшилася приблизно у 3,5 раза: із 14,5 тис. до 4 тис. зафіксованих випадків. Якщо ж говорити про два останні роки, то кількість таких порушень знизилася майже на 15\%: із 4750 випадків у 2018 р. до 4088 випадків у 2019 р. [4].

Людина не народжується особою, а стає нею у процесі свого розвитку, входження в соціальне середовище, засвоєння навколишньої дійсності, ідей, поглядів, норм моралі і звичок, поведінки, властивих соціуму, до якого вона належить. Процес, протягом якого особа розвивається і змінюється, отримуючи конкретне соціальне обличчя, називається соціалізацією. Дефектом соціалізації є особа злочинця, яка формується поступово. Погоджуємося з більшістю вітчизняних кримінологів, які вважають, що немає людей, приречених на вчинення злочинів, злочинцями вони стають внаслідок дефектів їх соціалізації [5, с. 46].

До основних причин, які зумовлюють злочинність неповнолітніх, належить: негативний вплив у сім’ї (тривала бездоглядність; зайва опіка і строгість; конфліктні сімейні стосунки), сфера негативного проведення дозвілля (у неповнолітніх правопорушників саме беззмістовне, бездіяльне проведення вільного часу в групі однолітків або старших товаришів разом із пляшкою спиртного, цигарками призводить до того, що такий спосіб життя стає звичкою, потім формує відповідні потреби), потреба у самоствердженні, вплив засобів масової інформації (Інтернет, телебачення, газети, радіо) [6]. Вважаємо, що сюди також можна віднести надмірну опіку. Адже недостатня увага, надмірний контроль, недовіра до дитини з боку батьків відштовхує дітей від них, втрачається довіра, почуття безпеки, дружби. Дитина замикається і шукає підтримки, розуміння та сприйняття ії поза сім'єю. На жаль, не завжди знаходить друзів, які соціально і право- 
мірно орієнтовані. I тут виникає конфлікт. Зрозуміло, що несформована психологічно дитина в межах свого віку, опинившись у конкретній життєвій ситуації під впливом багатьох факторів, не застрахована від того, що відбудеться злочинний прояв, тобто спрацює механізм злочинної поведінки. Вважаємо, що вплив батьківського виховання та найближчого оточення відіграє чи не найважливішу роль у формуванні правової спрямованості дитини та іiї соціалізації.

У повсякденному житті доволі часто можна почути такі поняття, як «неблагополучна сім'я», «малозабезпечені сім’ї», «недоглянуті діти». Більшість психологів, кримінологів, соціальних працівників приходять до єдиної думки, що діти з таких сімей, яким не приділяється достатньо уваги з боку батьків або осіб, які їх замінюють, більше схильні до вчинення правопорушень, порушення норм права та моралі.

Роль сім'ї у вихованні дитини неможливо переоцінити. Саме сім'я є першим природним середовищем, у якому відбувається становлення і розвиток особистості дитини, формування системи стійких моральних переконань, ціннісних орієнтирів [7, с. 190].

Психологи виділяють ще й соціально занедбаних дітей, які, маючи повну родину, не відчувають батьківського піклування, уваги. Досить часто заклопотані батьки, йдучи на роботу або залишаючи дітей на виховання няням, забувають, що для малят любов, увага, спільні ігри є фундаментом у формуванні особистості. Тож логічно згадати про наступну причину формування у дітей неправомірної поведінки - вплив засобів масової інформації. На нашу думку, доречніше сказати «надлишок» відеоігр, незрозумілих та абсурдних коротких роликів у соціальних мережах, безконтрольне проведення часу за комп'ютером, смартфоном, у соціальних мережах (для дітей молодшого шкільного віку). В силу незавершеності фізичного розвитку, психологічних властивостей діти нездатні правильно зрозуміти ту чи іншу інформацію, а безконтрольний перегляд відео, телебачення може спричинити психологічну шкоду здоров'ю дитини та стати причиною неправомірної поведінки в тій чи іншій конкретній життєвій ситуації.

Особливо загрозливим у цьому розумінні $є$ вік від 4 до 15 років - вік формування соціальності, коли людина вчиться відчувати інших, спілкуватися з іншими людьми. Якщо підліток «спілкується» 3 машиною, входить в ілюзорний світ - це відхід від реалій життя. Дуже часто підліткам спілкування з комп'ютером, який не образить і не образиться, замінює спілкування спочатку з однолітками, а пізніше - взагалі з іншими людьми [8].

Ми навели приклади, які, на нашу думку, є найбільш значущими причинами формування негативних соціально-психологічних властивостей особи та формування криміногенної мотивації неповнолітнього, які в певній ситуації можуть призвести до вчинення злочину.

Іншою, не менш вагомою, причиною вчинення протиправних діянь неповнолітніми є підбурювання з боку дорослих. Не секрет, що діти є довірливими, до них можна легко ввійти в довіру, в силу невеликого життєвого досвіду вони можуть не розпізнати людей, які обманом вчиняють 3 допомогою дитини протиправні дії. На жаль, досить велика кількість злочинів залишається латентними. Причини можуть бути різні: недовіра до правоохоронних органів, сором, недовіра до батьків або страх перед батьківським покаранням.

За даними прокуратури, кількість правопорушень проти дітей зросла майже на 20\% у 2020 р. проти 2019 р. Понад 5,2 тис. дітей постраждали від злочинів. На 37\% зросла кількість дітей, які постраждали від насильницьких дій сексуального характеру, зокрема згвалтування [9].

Висновки. Підводячи підсумки, слід згадати італійського мислителя, філософа, юриста Ч. Беккаріа, який вважав, що злочинність можна ліквідувати шляхом створення хороших, зрозумілих законів і просвітництва, виховання людей [3, с. 149]. Зазначимо, що в цьому аспекті вирішальними, на нашу думку, у профілактиці злочинності неповнолітніх та профілактиці формування протиправної поведінки у дітей є тісний взаємозв'язок і спілкування в колі сім'ї та правове виховання. Крім того, величезну роль мають відіграти школа, зокрема вчителі та психологи, які мають тісно взаємодіяти з батьками з метою підтримки правового виховання та запобігання розповсюдженню насильства й жорстокості. Вчителі мають вміти знаходити підхід до учнів, сприяти вирішенню та налагодженню відносин у колективі. Досить важливим $€$ також уміння вчителя виявляти детермінанти жорстокості у поведінці дітей та відповідним чином реагувати з метою недопущення негативних наслідків. 


\section{Використана література:}

1. Кідіна Н.В. Кримінологічні засади індивідуалізації покарання неповнолітніх в Україні : автореф. дис. ... канд. юрид. наук : 12.00.08. «Кримінальне право та кримінологія; кримінальновиконавче право» ; Національна академія внутрішніх справ . Київ, 2021. 20 с.

2. Кідіна Н.В. Кримінологічні засади індивідуалізації покарання неповнолітніх в Україні : дис. ... канд. юрид. наук : 12.00.08. Київ, 2021. 258 с.

3. Кончаковська В.В. Примушування давати показання: кримінально-правові та кримінологічні аспекти : дис... канд. юрид. наук : 12.00.08. Київ, 2010. 244 с.

4. Козлюк С. Обійти юність за гратами. Матеріал друкованого видання. № 29 (661). 2020. URL: https://tyzhden.ua/Society/245689 (дата звернення: 11.11.2021).

5. Кончаковська В. Особа злочинця у злочинах, що містять ознаки катування. Вісник Академії адвокатури України. 2009. № 3 (16). С. 46-51.

6. Шевчук Ю. Причини правопорушень серед дітей та відповідальність за їх скоєння. 2020. URL: https://gorodyshe.gr.org.ua/prychyny-pravoporushen-sered-ditej-ta-vidpovidalnist-za-yih-skoyennya/ (дата звернення: 11.11.2021).

7. Макарова О.В. Сім'я як основний інститут правової соціалізації дитини. Науковий часопис НПУ імені М.П. Драгоманова. Економіка і право. Серія № 18. Вип. 25. 2014. С. 190-194.

8. Про наслідки використання електронної техніки для розвитку здібностей дитини. URL: http://gymnasium83.edu.kh.ua/psihologichna_sluzhba_gimnazii/vam_lyublyachi_batjki/pro_ naslidki_vikoristannya_elektronnih_tehnichnih_priladiv_dlya_rozvitku_ditej/ (дата 11.11.2021).

9. Прокуратура створить канали довіри в соцмережах для неповнолітніх. 2021. URL: https://suspilne.media/110685-prokuratura-stvorit-kanali-doviri-v-socmerezah-dla-nepovnolitnih/ (дата звернення: 11.11.2021).

\section{References:}

1. Kidina, N.V. (2021). Kryminolohichni zasady indyvidualizatsii pokarannia nepovnolitnikh v Ukraini. [Principles of criminology of individualization of punishment of minor are in Ukraine] : avtoref. dys. ... kand. yuryd. nauk : 12.00.08. «Kryminalne pravo ta kryminolohiia; kryminalno-vykonavche pravo»; Natsionalna akademiia vnutrishnikh sprav . Kyiv. 20 s. [in Ukrainian].

2. Kidina, N.V. (2021). Kryminolohichni zasady indyvidualizatsii pokarannia nepovnolitnikh v Ukraini. [Principles of criminology of individualization of punishment of minor are in Ukraine] : dys. ... kand. yuryd. nauk : 12.00.08. Kyiv. 258 s. [in Ukrainian].

3. Konchakovska, V.V. (2010). Prymushuvannia davaty pokazannia: kryminalno-pravovi ta kryminolohichni aspekty. [Compulsion to give a testimony : criminal and legal and criminology aspects] : dys... kand. yuryd. nauk : 12.00.08. Kyiv. 244 s. [in Ukrainian].

4. Kozliuk, S. (2020). Obiity yunist za hratamy. [To go round youth behind bars]. Material drukovanoho vydannia. № 29 (661). 2020. Retrieved from: https://tyzhden.ua/Society/245689 [in Ukrainian].

5. Konchakovska, V. (2009). Osoba zlochyntsia u zlochynakh, shcho mistiat oznaky katuvannia. [The identity of the offevder in crimes that are signs of torture]. Visnyk Akademii advokatury Ukrainy, № 3 (16). S. 46-51 [in Ukrainian].

6. Shevchuk, Yu. (2020). Prychyny pravoporushen sered ditei ta vidpovidalnist za yikh skoiennia. [Causes of offenses among children and responsibility for their commision]. Retrieved from: https://gorodyshe. gr.org.ua/prychyny-pravoporushen-sered-ditej-ta-vidpovidalnist-za-yih-skoyennya/ [in Ukrainian].

7. Makarova, O.V. (2014). Simia yak osnovnyi instytut pravovoi sotsializatsii dytyny. [Family as basic institute of legal socialization of child]. Naukovyi chasopys NPU imeni M.P. Drahomanova. Ekonomika i parvo, Seriia № 18. Vyp. 25. S. 190-194 [in Ukrainian].

8. Pro naslidky vykorystannia elektronnoi tekhniky dlia rozvytku zdibnostei dytyny. [About the consequences of the use of electronic technique for developing flairs of child]. Retrieved from: http://gymnasium83.edu.kh.ua/psihologichna_sluzhba_gimnazii/vam_lyublyachi_batjki/pro_ naslidki_vikoristannya_elektronnih_tehnichnih_priladiv_dlya_rozvitku_ditej/ [in Ukrainian].

9. Prokuratura stvoryt kanaly doviry $\bar{v}$ sotsmerezhakh dlia nepovnolitnik $\bar{h}$. 2021. [The office of public prosecutor will create the channels of trust in TV for minor]. Retrieved from: https://suspilne.media/ 110685-prokuratura-stvorit-kanali-doviri-v-socmerezah-dla-nepovnolitnih/ [in Ukrainian]. 


\section{Konchakovska $V$. V., Makarova $O$. V. Reasons for the formation of criminogenic behavior in minors}

The article deals with the decisive role of the family in the upbringing of the child, the prevention of legal nihilism and the formation of criminal behavior in adolescents. The peculiarities of socialization of the child in the family are considered, as well as factors that influence the formation of criminogenic behavior of minors. The main disadvantages of family education are determined, crime statistics are analyzed among the minors over the past ten years.

The problem of family disadvantages is considered as a basic cause that affects the behavior of a minor. In addition, the following reasons for the formation of unlawful behavior of minors are allocated: the influence of the nearest environment (friends, school, neighbors, familiar), need for self-affirmation, excessive burns, mass media, disadvantages of school education, surplus video games and uncontrolled pastime for the computer Uther, smartphone, social networks.

Inexpensive is the influence of parental education and closest environment in the education of a child, its socialization and formation of legal orientation, on one side. From another - an unfavorable situation in the family, negative examples are concerned with a child and are transferred to conscious behavior and perceived as a norm.

Insufficient attention, excessive control, distrust of the child from parents, repels children from them, there is a trust, a sense of security, friendship, which in combination in a negative way is reflected in education and behavior, in particular.

On the basis of official statistics, it is stated that over the past 10 years there has been a decrease in the number of registered criminal offenses committed by minors (in particular from 2012 to 2020 by about 3.5 times: from 14.5 thousand to 4 thousand fixed cases).

The proposed model of teacher behavior in case of identification of problems in the children's team in order to prevent the attack on rights, freedom, honor, dignity, lawful interests of minors.

Key words: minor, violence, cruelty, reasons and terms of criminality, socialization, crime, reasons. 
Сизоненко А. $C$.

\section{ПРОФІЛАКТИКА ЮВЕНАЛЬНОЇ КРИМІНАЛЬНО ПРОТИПРАВНОӤ ДІЯЛЬНОСТІ ЯК ПРОВІДНИЙ МІЖНАРОДНИЙ СТАНДАРТ ЗАПОБІГАННЯ КРИМІНАЛІЗАЦІЇ НЕПОВНОЛІТНІХ}

У статті автор розглядає міжнародні стандарти запобігання криміналізації неповнолітніх. Особлива увага приділяється профілактищі ювенальної кримінально протиправної діяльності. Розділяючи думку щодо ширшого залучення громадськості щодо запобігання ювенальній злочинності та ефективної реалізації інституту громадського вихователя, автор наполягає на тому, що не треба нівелювати значенням запобіжної діяльності правоохоронних органів, які також повинні спрямовувати здійснення своїх повноважень на превениію ювенальної злочинності. Підтримується позиція вчених щзодо того, щчо запобігання злочинності, а особливо запобігання ювенальній злочинності має бути складовою частиною загальнодержавних програм щодо суспільного розвитку в різних сферах життя. Водночас для формування та реалізації таких програм необхідні достатні фінансові ресурси, яких у нашій країні бракує. Через відсутність достатнього обсягу матеріального забезпечення неможливо ефективно здійснювати заходи запобігання злочинності серед дітей шляхом реалізації відповідних загальнодержавних програм. Зазначається, що ювенальні суди та ювенальні судді під час здійснення правосуддя покликані враховувати фізіологічні, психологічні особливості дітей, які притягаються до відповідальності за вчинення правопорушень. Таке особливе відношення до дітей сприятиме виправленню та перевихованню підлітків та подальшому запобіганню ювенальній злочинності в державі. Підсумовується, щзо міжнародно-правовими стандартами запобігання ювенальній злочинності є: позитивна соціалізація дітей; профілактика ювенальної злочинності, створення системи ювенального правосуддя (правосуддя дружнього до дитини).

Ключові слова: міжнародні стандарти, неповнолітніх, ювенальний суд, профілактика, кримінальне правопорушення, запобігання криміналізації.

Ювенальна кримінально протиправна діяльність $є$ достатньо поширеним феноменом, який негативно впливає на загальну кримінологічну картину України. Загальновідомим є той факт, що одним із основних способів попередити кримінальне правопорушення є профілактика суспільно небезпечної поведінки особи, в тому числі - неповнолітньої. Про це свідчать і положення, викладені в міжнародних та європейських нормативно-правових актах та рекомендаціях із відправлення правосуддя у відношенні неповнолітніх осіб. Отже, враховуючи вказане, вважаємо за доцільне зупинитись більш детально на розгляді профілактики ювенальної кримінально протиправної діяльності як провідного міжнародний стандарту запобігання криміналізації неповнолітніх.

Відтак відповідно до п. 24 Керівних принципів запобігання злочинності серед неповнолітніх ООН необхідно розробити і використовувати спеціалізовані програми профілактичного характеру. ООН, ЮНЕСКО, Дитячий фонд ЮНІСЕФ та інші міжнародні організації значну увагу приділяють саме профілактиці негативних явищ у молодіжному середовищі. Чимало зусиль спрямовано на пошук нових чи адаптованих до сучасних умов життя підходів до здійснення профілактики правопорушень серед неповнолітніх [1, с. 382]. Оскільки найефективнішим напрямом превенції є своєчасне усунення криміногенних факторів зовнішнього середовища, а також створення антикриміногенних умов, за наявності яких правопорушник відмовиться від наміру вчинити правопорушення, а саме умов, які ускладнять учинення правопорушень, додадуть ризикованості діям й обмежать вигоду [1, с. 383].

Влучно відмічає Н.С. Юзікова, що суспільство має бути більш зацікавлене в запобіганні злочинів неповнолітніх, ніж у застосуванні заходів кримінально-правового впливу до них [2, с. 115]. Не можна не погодитись з авторкою в тому, що краще запобігати дитячій злочин- 
ності, аніж застосовувати до дітей заходи кримінально-правового характеру. У зв'язку із цим украй важливе значення набуває профілактика ювенальної злочинності.

Система профілактики злочинності у цілому та злочинів, що вчиняються неповнолітніми, зокрема в сучасних умовах, має враховувати позитивний досвід, а також нові вимоги суспільства. При цьому слід виходити з такого:

- поєднання державних і суспільних засад, сил і ресурсів такої діяльності;

- здійснення комплексного впливу на особу, середовище, діяльність суб'єктів виховання та профілактики, громадську думку;

- розподіл функцій між окремими учасниками профілактичної діяльності з тим, щоб уникнути дублювання;

- визначення сфери застосування заходів виховання, забезпечення нормальних життєвих умов, соціальної допомоги та власне профілактики, включаючи правові їі форми [3, с. 111].

Отже, система профілактики ювенальної злочинності включає декілька аспектів, у тому числі об'єднання державної, суспільної та громадської складових частин, а також поєднання виховної та профілактичної складових, їх комплексного впливу.

Виховну та запобіжну роботу серед молоді проводять ради сприяння родині та школі, батьківські комітети, ради ветеранів війни та праці, громадські вихователі неповнолітніх та ін. Відмітимо, що до основних завдань діяльності вказаних органів, зокрема батьківського комітету, належать: сприяння створенню умов для формування та розвитку особистості учня та його громадянської позиції, становлення учнівського самоврядування; формування загальнолюдської культури і моралі, культури міжетнічних відносин; взаємодія з педагогічним колективом загальноосвітньої установи з питань профілактики правопорушень, бездоглядності та безпритульності серед неповнолітніх учнів; всебічне зміцнення зв'язків між родинами, навчальним закладом і громадськістю з метою встановлення єдності їхнього виховного впливу на дітей; залучення батьківської громадськості до професійної орієнтації учня, позакласної та позашкільної роботи тощо. Крім того, вищезазначені органи мають великі можливості для виявлення неблагополучних сімей, в яких батьки зловживають алкоголем, ведуть аморальний спосіб життя, та вжиття необхідних заходів щодо покращення умов виховання в окремих родинах або звернення до відповідних державних органів [4, с. 313]. Аналогічний чинник запобігання злочинності неповнолітніх наводить А.Ю. Дзюба, який, розглядаючи питання про загальносоціальні заходи запобігання злочинності неповнолітніх як один із напрямів кримінологічної політики ФРН, наголошує на створенні спеціальних служб допомоги учням: бесіди щодо шкоди паління, вживання алкоголю і наркотиків, консультації із приводу статевих стосунків, вирішення конфліктів, допомога тим, хто відстає в навчанні [3, с. 313]. Свропейська філософія дружнього відношення до підлітка, який вступив у конфлікт із законом, полягає в залученні якомога більше служб, які здатні позитивно впливати на його поведінку без застосування надмірної репресії [3, с. 96]. Якщо розглядати соціальні служби крізь призму європейських правових стандартів, то необхідно відмітити, що саме вони повинні здійснювати превентивну функцію, виділяючи серед дітей осіб, які мають девіантну поведінку, виховуються в неблагонадійних та неповних родинах, позбавлені батьківської уваги та нормального виховання тощо $[5$, с. 96$]$.

Окрім того, А.Ю. Дзюба акцентує увагу на тому, що в умовах формування правової держави особлива увага повинна приділятися не лише проблемам захищеності особи правом, іiі правової інформованості, а й її культурному та трудовому вихованню, розвитку сім'ї. Особливою і досить важливою є специфіка самого процесу сімейного виховання. Досліджуючи сімейне виховання, необхідно, в першу чергу, відмітити його безперервність, тривалість і різнобічність. У цьому сенсі з родиною не може зрівнятися жодний інший виховний інститут [3, с. 114]. Залучення родини до перевиховання неповнолітнього правопорушника, а також спільне відвідування батьками з підлітками спеціальних реабілітаційних курсів дозволить їм швидше досягти мети перевиховання, а також зблизить членів родини [5, с. 98].

О.М. Самойлова зазначає, що одним із дієвих методів участі представників громадськості в запобіганні злочинності неповнолітніх $є$ проведення регулярних рейдів за участі батьків, 
вчителів по місцях концентрації підлітків та молоді з метою виявлення місць, в яких можуть виникнути несприятливі умови їх морального виховання, а також усунення або послаблення джерел такого впливу. Особливу увагу слід звертати на перевірку суб'єктів підприємницької діяльності стосовно недопущення порушень правил торгівлі, заборони продажу неповнолітнім тютюнових виробів та спиртних напоїв [4, с. 313]. Таким чином, досягнення бажаних результатів у запобіганні злочинам неповнолітніх уявляється можливим лише за умови налагодження тісної взаємодії державних органів із громадськістю. Очевидною є необхідність активніше залучати до цієї діяльності громадські організації та формування, пересічних громадян, тим самим розвиваючи соціально-правову активність останніх. Не викликає жодного сумніву, що чим більше людей включатиметься в цю роботу, тим успішнішою вона буде [4, с. 313].

Залучення громадськості до роботи з неповнолітніми правопорушниками $є$ одним із шляхів запобігання та протидії сучасній протиправній діяльності, а також можливим варіантом звільнення їх від покарання та його відбування. Цю думку підтверджує створення інституту громадського вихователя, який на сьогодні втратив свою дієвість через недосконалість ювенального кримінального законодавця та зниження відповідальності та громадської позиції суспільства [5, c. 100].

Розділяючи думку щодо ширшого залучення громадськості щодо запобігання ювенальній злочинності та ефективної реалізації інституту громадського вихователя, все ж таки вважаємо, що не треба нівелювати значення запобіжної діяльності правоохоронних органів, які також повинні спрямовувати здійснення своїх повноважень на превенцію ювенальної злочинності.

Разом із тим О.П. Заворіна акцентує увагу на тому, що превентивна діяльність правоохоронних органів та інших органів влади України дещо ізольована від суспільства й часто не може контролювати розвиток кримінальної ситуації у країні. Натомість у більшості розвинутих країн запобігання злочинності є частиною загальнодержавних програм соціального та економічного розвитку [6, с. 153]. Повністю підтримуємо авторку в тому, що запобігання злочинності, а особливо запобігання ювенальній злочинності має бути складовою частиною загальнодержавних програм щодо суспільного розвитку в різних сферах життя. Водночас для формування та реалізації таких програм необхідні достатні фінансові ресурси, яких в нашій країні бракує. Через відсутність достатнього обсягу матеріального забезпечення неможливо ефективно здійснювати заходи запобігання злочинності серед дітей шляхом реалізації відповідних загальнодержавних програм.

Як вірно підкреслює А.О. Йосипів, системи освіти й охорони здоров'я, наукові установи через мізерне фінансування, брак спеціальних кадрів, нерозвинену мережу й матеріально-технічну базу закладів не змогли швидко розробити та впровадити методи і засоби профілактики, діагностики, лікування та реабілітації дітей і підлітків із маргінального середовища [1, с. 384]. А.Ю. Дзюба, дослідивши питання про загально соціальні заходи запобігання злочинності неповнолітніх як один із напрямів кримінологічної політики ФРН, наголошує на використанні принципу субсидіарності, коли основна відповідальність, у тому числі фінансова, покладається на найбільш наближений до неповнолітніх рівень. У Німеччині близько 60\% витрат на реалізацію молодіжних програм припадає на комунальний рівень (близько $10 \%$ комунального бюджету), 35\% - на рівень відповідних земель. Це дає можливість надавати допомогу молоді 3 урахуванням локальних і регіональних соціально-економічних реалій і потреб [3, с. 113]. Застосування такого принципу субсидіарності щодо реалізації загальносоціальних програм стосовно запобігання ювенальній злочинності уявляється досить перспективним. Такий розподіл фінансових витрат може бути здійснений у нашій державі для підвищення рівня запобігання злочинності серед дітей.

Окреслений підхід до запобігання ювенальної злочинності буде відповідати змісту Рекомендації N Rec (2003) 20 Комітету міністрів Ради Свропи державам-членам «Про нові підходи до злочинності серед неповнолітніх та про значення правосуддя у справах неповнолітніх», відповідно до якого попередження злочинності серед неповнолітніх має плануватися, координуватися і фінансуватися місцевими партнерами, включаючи ключові державні установи: поліцію, служби пробації, соціального забезпечення та у справах неповнолітніх, судові органи, 
установи освіти, зайнятості, охорони здоров'я та житлово-комунальні господарства, добровільний та приватний сектор [7]. Для подальшого становлення й розвитку вітчизняної системи профілактики правопорушень серед неповнолітніх, розроблення та впровадження в діяльність суб'єктів цієї профілактики нових ефективних форм і методів слід вивчати й упроваджувати закордонні методичні напрацювання, практичні прийоми в цій сфері, ураховуючи національні особливості, пов'язані з історичним розвитком нашої держави та сучасними трансформаційними процесами, що тривають у всіх сферах суспільного життя [1, с. 389].

Аналіз правових систем і норм розвинених зарубіжних країн із профілактики правопорушень серед дітей доводить, що практично скрізь діє єдина скоординована, цілісна система попередження правопорушень неповнолітніх осіб та притягнення їх до юридичної та інших видів відповідальності. Зусилля всіх державних органів у даному випадку спрямовані на вирішення однієї складної глобальної проблеми, яка набула пріоритетності в усьому світі. Політика Великобританії є яскравим прикладом громадсько-інтегративного підходу профілактики правопорушення неповнолітніх, Франція має яскраво виражені ознаки реституційної моделі, Японія здійснює акцент на ресоціалізації неповнолітніх. Однак у профілактичних системах високорозвинених країн ми помічаємо й ознаки інших підходів. Так, у Німеччині, окрім ресоціалізації, увага приділяється й каральному аспекту, а також розгалуженою $є$ система взаємодії різних органів та установ. У Великобританії, де найвагомішу роль відіграє громада, є й високорозвинена ресоціалізаційна система. Японія, окрім методів ресоціалізації, не оминає увагою необхідність співпраці різних урядових структур [8]. Таким чином, найефективніші програми базуються на мультифакторному підході та застосовуються починаючи з періоду раннього дитинства, спрямовані не стільки на індивіда (агресивна поведінка, стрес, навички подолання), скільки на несприятливі характеристики найближчого сімейного та соціального оточення. Вважаємо, що така програма може використовуватися для профілактики злочинності дітей, тому що досить часто причиною їх девіантної поведінки є недоліки в сімейному вихованні [9, с. 142].

Вважаємо, що ефективна система профілактики правопорушень неповнолітніх має поєднувати в собі ознаки різних концепцій: об’єднувати громадські ініціативи задля профілактики девіацій серед дітей, мати структуровану систему ресоціалізації, у якій співпрацюють між собою різні державні установи, не уникати можливості відновлювального правосуддя, що $€$ однією із сутнісних ознак реституційного підходу, за необхідності до правопорушника мають бути застосовані каральні заходи. Зважаючи на досвід впровадження системи профілактики в зарубіжних країнах, найбільш перспективним для запровадження в Україні, на нашу думку, $€$ позитивний досвід Германії та Франції, де принцип індивідуального підходу до неповнолітніх правопорушників виражений у найбільш сприятливій формі в тому числі й на структурному рівні. Йдеться про створення в системі правоохоронних органів підрозділів, які б представляли структуру, створену з числа кваліфікованих педагогів, психологів, а також інших вузькопрофільних спеціалістів [8].

Історія ювенальної юстиції внесла корективи у традиційне уявлення про безспірні переваги автономного правосуддя зі справ неповнолітніх. У світі розвинулися варіанти таких судів колегії, склади суду, які розглядають справи неповнолітніх і діють не автономно, а як частина загальних судів. Усе ж таки з урахуванням історичних змін можна вести мову про відокремленість суду зі справ неповнолітніх, яка зумовлена комплексом правових норм (матеріальних і процесуальних), що в сукупності становлять його автономність. Значна частина цих правових норм застосовується лише у правосудді зі справ неповнолітніх [3, с. 65].

Ювенальний суд вирізняється тільки йому притаманними ознаками, а саме: 1) у всіх країнах, де такий суд існує, на початкових стадіях розгляду справи він виступає магістратом, мировим суддею і діє одноособово; 2) до освіти, професії й життєвого досвіду судді висуваються особливі вимоги: йому не обов'язково бути правником, а перевага віддається психологам, педагогам, лікарям; 3) там, де в системі правосуддя $є$ суд присяжних у справах неповнолітніх, аналогічні вимоги мають висуватись і до присяжних (до речі, існують спеціальні правила складання списків присяжних та їх відбору); 4) цей суд здійснює правосуддя, використовуючи різноманітні допоміжні неюридичні служби; 5) правосуддя реалізується відповідно до особливостей судової процедури, 
в центрі якої знаходиться неповнолітній і суддя; 6) він розвивається нині як суд комплексної, змішаної юрисдикції (прикладом можуть стати опікунські суди в Австрії, правомочні розглядати й вирішувати в одній справі питання про правопорушення, яке вчинив підліток, і цивільно-правового захисту останнього); 7) має специфічну персональну і предметну підсудність. У першому випадку йдеться про такі варіанти, як розгляд справ тільки неповнолітніх, розгляд справ і дорослих співучасників та передача справ у загальні суди. У другому - розгляд діянь, які вважаються правопорушеннями лише у випадках учинення їх неповнолітніми (так звані статусні злочини) [3, с. 65]. Ювенальні суди та ювенальні судді під час здійснення правосуддя покликані враховувати фізіологічні, психологічні особливості дітей, які притягаються до відповідальності за вчинення правопорушень. Таке особливе відношення до дітей сприятиме виправленню та перевихованню підлітків та подальшому запобіганню ювенальній злочинності в державі.

Окрім ювенальних судів, на запобігання ювенальній злочинності спрямовано функціонування інших установ та органів. Як слушно підкреслюється в юридичній літературі, ювенальна юстиція - це не лише ювенальні суди, а ціла система взаємодії судової влади, державних та громадських інституцій, закріплена на законодавчому рівні [10, с. 217]. Серед таких органів та інституцій у системі кримінального судочинства можна виокремити ювенальних (спеціалізованих) адвокатів, слідчих та прокурорів, на запровадження яких наголошується у правовій літературі [11, с. 174].

Як із боку сторони захисту, так і з боку сторони обвинувачення під час досудового розслідування та судового провадження мають враховуватися особливості фізіологічного та психічного розвитку дитини. Оскільки перед тим як дитина предстане перед ювенальним судом, із нею будуть контактувати у процесуальному сенсі представники сторін кримінального провадження. Взаємовідносини підлітка з дізнавачем, слідчим, оперативним співробітником, прокурором, захисником зумовлюватиме відношення дитини до представників кримінальної юстиції та формуватиме бажання щодо майбутньої злочинної діяльності. У зв'язку із цим створення ювенальних органів обвинувачення та ювенальної адвокатури нерозривно пов'язано із запобігання дитячої злочинності.

Таким чином, міжнародно-правовими стандартами запобігання ювенальній злочинності є: позитивна соціалізація дітей; профілактика ювенальної злочинності, створення системи ювенального правосуддя (правосуддя дружнього до дитини).

\section{Використана література:}

1. Йосипів А.О. Зарубіжний досвід запобігання злочинам, що вчиняють неповнолітні з маргінального середовища. Юридичний часопис Національної академії внутрішніх справ. 2018. № 1. С. 381-392.

2. Юзікова Н.С. Заходи запобігання злочинності неповнолітніх за радянських часів. Юридичний вісник. Повітряне і космічне право. 2011. № 4. С. 111-115.

3. Дзюба А.Ю. До питання про загально соціальні заходи запобігання злочинності неповнолітніх як один із напрямів кримінологічної політики ФРН. Вісник Харківського національного університету внутрішніх справ. 2017. Вип. 4. С. 109-116.

4. Самойлова О.М. Запобігання злочинності неповнолітніх за участю громадськості. Право $і$ суспільство. 2013. № 6.2. С. 311-314.

5. Вітвіцький С.С., Назимко Є.С., Тіточка Т.І. Звільнення неповнолітніх від покарання та його відбування: міжнародні та європейські правові стандарти: монографія. Київ : ВД «Дакор», 2021. $134 \mathrm{c}$.

6. Заворіна О.П. Міжнародний досвід протидії підрозділами національної поліції вбивствам, які вчиняються неповнолітніми. Форум права. 2017. № 5. С. 148-156.

7. Рекомендация N Rec (2003) 20 Комитета министров Совета Европы государствам-членам «О новых подходах к преступности среди несовершеннолетних и о значении правосудия по делам несовершеннолетних» (24 сентября 2003 года). URL : https://zakon.rada.gov.ua/laws/ show/994 865\#Text.

8. Мураненко К.Ю. Зарубіжний досвід профілактики правопорушень серед неповнолітніх. Психологічний часопис. 2019. № 2. С. 85-98. 
9. Семенишин М.О. Зарубіжний досвід запобігання корисливо-насильницьким злочинам, що вчиняються дітьми. Наше право. 2020. № 1. С. 139-146.

10. Дмитришина Т. Ювенальна юстиція: міжнародний досвід та перспективи його впровадження в Україні. Підприємництво, господарство і право. 2021. № 1. С. 210-219.

11. Ольшанецький I. В. Ювенальна юстиція - проблеми законодавчого врегулювання іiі органів в Україні (ювенальний суддя, прокурор, слідчий, адвокат). Правова держава. 2020. № 37. С. 45-56.

\section{References:}

1. Yosypiv A. O. Zarubizhnyy dosvid zapobihannya zlochynam, shcho vchynyayut' nepovnolitni z marhinal'noho seredovyshcha. Yurydychnyy chasopys Natsional'noyi akademiyi vnutrishnikh sprav. 2018. № 1. S. 381-392.

2. Yuzikova N.S. Zakhody zapobihannya zlochynnosti nepovnolitnikh za radyans'kykh chasiv. Yurydychnyy visnyk. Povitryane i kosmichne pravo. 2011. № 4. S. 111-115.

3. Dzyuba A.YU. Do pytannya pro zahal'no sotsial'ni zakhody zapobihannya zlochynnosti nepovnolitnikh yak odyn iz napryamiv kryminolohichnoyi polityky FRN. Visnyk Kharkivs'koho natsional'noho universytetu vnutrishnikh sprav. 2017. Vyp. 4. S. 109-116.

4. Samoylova O.M. Zapobihannya zlochynnosti nepovnolitnikh za uchastyu hromads'kosti. Pravo i suspil'stvo. 2013. № 6.2. S. 311-314.

5. Vitvits'kyy S.S., Nazymko YE.S., Titochka T.I. Zvil'nennya nepovnolitnikh vid pokarannya ta yoho vidbuvannya: mizhnarodni ta yevropeys'ki pravovi standarty: monohrafiya. Kyyiv: VD «Dakor», 2021. $134 \mathrm{~s}$.

6. Zavorina O.P. Mizhnarodnyy dosvid protydiyi pidrozdilamy natsional'noyi politsiyi vbyvstvam, yaki vchynyayut'sya nepovnolitnimy. Forum prava. 2017. № 5. S. 148-156.

7. Rekomendatsyya N Rec (2003) 20 Komyteta mynystrov Soveta Evropy hosudarstvam-chlenam «O novykh podkhodakh $\mathrm{k}$ prestupnosty sredy nesovershennoletnykh y o znachenyy pravosudyya po delam nesovershennoletnykh» (24 sentyabrya 2003 hoda). URL: https://zakon.rada.gov.ua/laws/ show/994 865\#Text

8. Muranenko K. YU. Zarubizhnyy dosvid profilaktyky pravoporushen' sered nepovnolitnikh. Psykholohichnyy chasopys. 2019. № 2. S. 85-98.

9. Semenyshyn M.O. Zarubizhnyy dosvid zapobihannya koryslyvo-nasyl'nyts'kym zlochynam, shcho vchynyayut'sya dit'my. Nashe pravo. 2020. № 1. S. 139-146.

10. Dmytryshyna T. Yuvenal'na yustytsiya: mizhnarodnyy dosvid ta perspektyvy yoho vprovadzhennya $\mathrm{V}$ Ukrayini. Pidpryyemnytstvo, hospodarstvo i pravo. 2021. №1. S. 210-219.

11. Ol'shanets'kyy I. V. Yuvenal'na yustytsiya - problemy zakonodavchoho vrehulyuvannya yiyi orhaniv v Ukrayini (yuvenal'nyy suddya, prokuror, slidchyy, advokat). Pravova derzhava. 2020. № 37. S. 45-56.

\section{Syzonenko A. S. Prevention of juvenile criminal activity as a leading international standard for the prevention of juvenile delinquency}

In the article the author considers the international standards of prevention of criminalization of minors. Particular attention is paid to the prevention of juvenile criminal activity. Sharing the view on wider public involvement in the prevention of juvenile delinquency and the effective implementation of the institution of public educator, the author insists that the importance of preventive activities of law enforcement agencies, which should also direct their powers to prevent juvenile delinquency. The position of scientists is supported that the prevention of crime, and especially the prevention of juvenile crime should be part of national programs for social development in various spheres of life. At the same time, the formation and implementation of such programs requires sufficient financial resources, which are lacking in our country. Due to the lack of sufficient material support, it is impossible to effectively implement measures to prevent crime among children through the implementation of appropriate national programs. It is noted that juvenile courts and juvenile judges in the administration of justice are designed to take into account the physiological, psychological characteristics of children who are prosecuted for offenses. Such a special treatment of children will contribute to the correction and re-education of adolescents and the further prevention of juvenile delinquency in the state. It is concluded that the international legal standards for the prevention of juvenile delinquency are: positive socialization of children; prevention of juvenile delinquency, creation of a juvenile justice system (child-friendly justice).

Key words: international standards, juveniles, juvenile court, prevention, criminal offense, prevention of criminalization. 
Терехов В. Ю.

\section{НОРМАТИВНО-ПРАВОВИЙ АНАЛІЗ РОБОТИ ПРАВООХОРОННИХ ОРГАНІВ В УМОВАХ НЕСПРИЯТЛИВОЇ ЕПІДЕМОЛОГІЧНОЇ СИТУАЦЇ̈ (НА ПРИКЛАДІ ПРОТИДІЇ ГОСТРІЙ РЕСПІРАТОРНІЙ ХВОРОБІ СОVID-19)}

У статті проведено аналіз правових засобів забезпечення гарантій роботи правоохоронних органів в умовах несприятливої епідеміологічної ситуаџї̈ (на прикладі протидії гострій респіраторній хворобі COVID-19, спричиненої коронавірусом SARS-CoV-2) та запроваджено: удосконалити нормативне регулювання правового режиму пандемії COVID-19 та реалізації повноважень у сфері протиепідеміологічної роботи органами безпеки та правопорядку; внести зміни до законодавства та відомчих правових актів з питань медичного забезпечення, страхування та грошової допомоги праиівникам та військовослужбовиям правоохоронних органів, які забезпечують дотримання карантинної дисципліни та життєдіяльності населення на період дї карантину; розмежувати правоохоронні та інші функиії у протиепідеміологічній роботі, визначити напрями спільної діяльності з метою протидії поширенню COVID-19; забезпечити методологічну та консультативну підтримку для працівників поліиії під час реалізації адміністративно-юрисдикиійної діяльності.

Метою правових засобів забезпечення гарантій роботи правоохоронних органів $є$ забезпечення безпеки, захищеності та інституційної спроможності діяльності органів безпеки, правопорядку в екстремальних умовах, зокрема при поширенні захворювань.

Участь правоохоронних органів в умовах пандемії необхідно розглядати у таких сценаріях: перший - застосування адміністративно-юрисдикиійних повноважень для виявлення та припинення фактів недотримання карантинних обмежень шляхом складання адміністративних матеріалів та розслідування фактів вчинення злочинів у межах повноважень; другий - підсилення правоохоронного моніторингу та контролю за недопущенням, виявленням та припиненням протизаконних дій, які супроводжуються режимом карантинних обмежень (наприклад, домашне насилля, кіберправопорушення, вандалізм, мародерство, хуліганство, тощо); третій - посилення процесів безпекової та правоохоронної взаємодії поліиії, санітарно-епідеміологічної служби, служби охорони здоров'я та надзвичайних ситуачій, прикордонної служби, Національної гвардії, органів національної безпеки, муніципальних варт, громадських об 'єднань задля забезпечення життєдіяльності країни в умовах COVID-19.

Ключові слова: COVID-19, несприятлива епідеміологічна обстановка, правоохоронні органи, життєдіяльність населення, епідеміологічний контроль.

\section{Вступ}

Епідемія COVID-19 продемонструвала слабкість та фактичну неспроможність протистояти викликам санітарно-біологічної небезпеки навіть найпотужнішими державами світу. Глобальний прояв пандемії не залишив осторонь і Україну. Навіть через два роки масштаб впливу помітний в усіх сферах суспільного життя, починаючи із сфери охорони здоров'я та закінчуючи проблемою економічної стагнації і кризи.

\section{Постановка проблеми}

На наш погляд, саме діяльність правоохоронних органів потребує безперебійності виконання обов'язків їх посадовими особами в умовах карантину. Зважаючи на необхідність здійснення додаткових завдань із попередження та протидії поширенню коронавірусної хвороби, здоров'ю та життю правоохоронців існують реальні загрози. Зокрема, за даними МВС України, всього з початку пандемії на COVID-19 захворіло 11389 правоохоронців, одужало 10 545, померло - 29. Водночас із початку карантинних обмежень до органів поліції надійшло 134067 повідомлень, пов'язаних із порушенням карантинних заходів. Поліцейські склали 52003 адміністративних протоколи та розпочали 445 кримінальних проваджень [13, с. 14]. Відсутність комплексного підходу до управління правоохоронною діяльністю в умовах погіршення епідеміологічної ситуації несе ризики дестабілізації усієї правоохоронної системи. 
3 урахуванням наявного негативного досвіду одним із завдань для подальшого удосконалення правоохоронної функції є забезпечення гарантій безпеки, захищеності та інституційної спроможності діяльності органів правопорядку в екстремальних умовах, зокрема, при поширенні захворювань.

Meта статmi полягає в проведенні нормативно-правового аналізу загальних питань діяльності правоохоронних органів в умовах протидії COVID-19.

\section{Виклад основного матеріалу}

Аналізуючи діяльність органів правоохорони в умовах COVID-19, Б.О. Логвиненко зауважує, що Національна поліція залишилася фактично єдиним суб'єктом, наділеним повноваженнями застосовувати заходи адміністративного примусу щодо дотримання карантинних вимог [6, с. 50]. Це стало результатом декількох факторів, подій: по-перше, концентрація адміністративно-юрисдикційних повноважень із розгляду справ про адміністративні правопорушення виключно в органах Національної поліції України; по-друге, ліквідація у 2012 році Державної санітарно-епідеміологічної служби [7], яка відповідно до покладених на неї завдань здійснювала державний санітарно-епідеміологічний нагляд за дотриманням вимог санітарного законодавства органами виконавчої влади та органами місцевого самоврядування, підприємствами, установами, організаціями незалежно від форм власності та господарювання та громадянами [9].

Проте органи Національної поліції не єдині, які безпосередньо виконують функції забезпечення життєдіяльності населення в умовах протидії епідемії. Національна гвардія, Державна прикордонна служба України, Державна служба надзвичайних ситуацій фактично долучені до правоохоронних завдань щодо виконання обов'язків, які пов'язані із безпосереднім ризиком зараження COVID-19.

За наявності стратегічних прорахунків у нормотворенні, недалекоглядності управління системою забезпечення здоров'я та життєдіяльності населення при COVID-19 утворилася кризова ситуація, що пов'язана із дезорганізацією координації служб охорони здоров'я, правоохоронних органів та інших суб'єктів забезпечення життєдіяльності населення. Зауважуємо, що наявність чіткого нормативно-правового забезпечення міжвідомчої координації в кризових ситуаціях $\epsilon$ визначальним чинником для ефективності та дієвості реалізації органами правопорядку протиепідеміологічної роботи.

Фактором ефективності правоохоронної функцій та створення гарантій виконання завдань забезпечення правопорядку в умовах, які склалися при COVID-19, є правовий режим пандемії в загальнонаціональному правовому полі.

Згідно зі ст. 11 Кодексу цивільного захисту України, єдина державна система залежно від масштабів і особливостей надзвичайної ситуації, що прогнозується або виникла, функціонує у режимах за ступенем градації: повсякденного функціонування; підвищеної готовності; надзвичайної ситуації; надзвичайного стану [3]. Ч. 1 ст. 28 зазначеного Кодексу передбачено, що для ліквідації наслідків надзвичайних ситуацій відповідно до закону можуть залучатися Збройні Сили України, інші військові формування та правоохоронні органи спеціального призначення, утворені відповідно до законів України [3].

Як відомо, згідно зі ст. 4 Закону України «Про правовий режим надзвичайного стану», підставою для введення правового режиму надзвичайного стану є реальна загроза безпеці громадян або конституційному ладові, усунення якої іншими способами неможливе [11]. Відповідно до ч. 1 ст. 4 вищезазначеного Закону, виникнення особливо тяжких надзвичайних ситуацій техногенного та природного характеру (стихійного лиха, катастроф, особливо великих пожеж, застосування засобів ураження, пандемій тощо), що створюють загрозу життю і здоров'ю значних верств населення, є однією із умов введення надзвичайного стану [11]. Суб'єктами, уповноваженими здійснювати контроль за дотриманням обмежень у зв'язку із надзвичайним станом, визначено органи Національної поліції, Національної гвардії України, Служби безпеки України, Військової служби правопорядку у Збройних Силах України [11]. Отже, будьякий правовий режим, що виникає в результаті чинників техногенного чи антропогенного походження, передбачає застосування сил та засобів органів правопорядку, а також військових формувань $з$ правоохоронними функціями для його комплексного подолання. 
На відміну від низки країн Європи, Україна не вводила режим надзвичайного стану, незважаючи на те, що прямі законні підстави існували, особливо в період загострення періоду спалаху інфекції навесні 2020 року. Натомість уповноваженими органами не введено жодного 3 правових режимів, який передбачений Кодексом цивільного захисту населення України. Низку обмежень, які визначали особливий характер функціонування всієї держави в умовах COVID-19, було регламентовано так званим «карантинним режимом». Основним недоліком зазначеного правового режиму із обмежувальними заходами є відсутність чіткого алгоритму державно-правового впливу на забезпечення життєдіяльності держави та протидію пандемії. Правове забезпечення діяльності органів правопорядку, відповідно, також не містить системного підходу в організації протиепідеміологічних функцій.

Констатується, що Закон України «Про внесення змін до деяких законодавчих актів України, спрямованих на запобігання виникненню і поширенню коронавірусної хвороби (COVID-19)» від 17.03.2020 № 530-IX [8] є основним нормативним документом, який спрямований на визначення особливостей реагування держави в умовах карантину. Проте в результаті аналізу його положень можна дійти висновку, що він не містить жодної системоутворюючої норми, яка передбачала б загальні засади управління діяльністю органів влади для припинення поширення коронавірусної інфекції. Отже, так званий «Закон про COVID-19» є за своєю природою тимчасовим правовим актом, що не може претендувати на постійний характер та потребуватиме внесення релевантних доповнень з урахуванням змін епідеміологічної обстановки.

Законом України «Про захист населення від інфекційних хвороб», визначено лише, що карантин - це перелік адміністративних та медико-санітарних заходів, що застосовуються для запобігання поширенню особливо небезпечних інфекційних хвороб [10]. Питання також виникають у визначенні переліку адміністративних заходів, якими описується термін «карантин» у Законі України «Про захист населення від інфекційних хвороб».

Оскільки чинне законодавство не визначає карантин як особливий правовий режим, відсутній інституційний підхід до залучення правоохоронних органів для вжиття протиепідеміологічних заходів з метою дотримання обмежень, пов'язаних із ним.

Прогте у науковій літературі вже сформувалося цілісне уявлення про національну модель «ковідного» карантину, яку можна використати в подальшому удосконаленні роботи правоохоронних органів для цілей протидії COVID-19. Наприклад, M.В. Колеснікова пропонує розглядати «адміністративно-правовий режим пандемії COVID-19» з урахуванням комбінації наявних у чинному законодавстві термінів. Вчена вважає, що карантин як адміністративноправовий режим зумовлений постійно мінливими чинниками поширення вірусного захворювання, враховуючи природу цього явища, є режимом непостійним [4, с. 79]. Термін «режим повної ізоляції» згадується у праці А. Вознюк та С. Чернявського [2, с. 8]. Формулювання «адміністративно-правовий режим забезпечення санітарно-епідеміологічного благополуччя» використано у праці В.М. Редкоуса [12]. В.В. Бухарєв та О.М. Рєзнік пропонують вживання правового режиму «самоізоляції» як обов'язкового елементу дотримання режиму карантину при COVID-19, який забезпечується шляхом обмеження основних прав і свобод людини (наприклад, обов'язкова госпіталізація передбачає обмеження права на свободу та особисту недоторканість, а обов'язок постійно перебувати у визначеному місці самоізоляції - обмеження права на свободу пересування) [1].

На наш погляд, адміністративно-правовий режим карантину в умовах COVID-19 в Україні в контексті діяльності органів правоохорони, безпеки та правопорядку слід розглядати як сукупність обмежувальних заходів, які залежно від рівня епідеміологічної обстановки застосовуються уповноваженими суб'єктами протиепідеміологічної діяльності з метою дотримання карантинної дисципліни та забезпечення життєдіяльності країни.

Особливістю нормативно-правового забезпечення діяльності органів правопорядку при COVID-19 є несистемна (точкова) модель вжиття заходів, що виглядає як форма реалізації компетенції. Але якщо повноваження Національної поліції України чітко визначені підвідомчістю адміністративних та кримінальних правопорушень, то діяльність інших суб'єктів антиковідної роботи не завжди має чітке нормативне визначення. 
Наприклад, аналізуючи нормативно-правове забезпечення діяльності Національної гвардії України, констатуємо відсутність положень щодо реалізації протиепідеміологічної компетенції.

Тому з методологічної позиції участь правоохоронних органів в умовах пандемії необхідно розглядати у таких сценаріях: (1) перший - застосування адміністративно-юрисдикційних повноважень для виявлення та припинення фактів недотримання карантинних обмежень шляхом складання адміністративних матеріалів та розслідування фактів вчинення злочинів в межах повноважень; (2) другий - підсилення правоохоронного моніторингу та контролю за недопущенням, виявленням та припиненням протизаконних дій, які супроводжуються режимом карантинних обмежень (наприклад, домашне насилля, кіберправопорушення, вандалізм, мародерство, хуліганство, тощо); (3) третій - посилення процесів безпекової та правоохоронної взаємодії поліції, санітарно-епідеміологічної служби, служби охорони здоров'я та надзвичайних ситуацій, прикордонної служби, Національної гвардії, органів національної безпеки, муніципальних варт, громадських об’єднань задля забезпечення життєдіяльності країни в умовах COVID-19.

Що стосується саме пандемії COVID-19, то іï слід охарактеризувати високим ступенем ураження та швидкістю поширення. А тому створення загрози стрімкого поширення хвороби у масових масштабах може бути підставою вчинення діяння, яке охоплюється ознаками злочину, передбаченого статтею 325 Кримінального кодексу України «Порушення санітарних правил і норм щодо запобігання інфекційним хворобам та масовим отруєнням» [5].

При цьому важливо відзначити не тільки важливість будь-якого свідомого громадянина, суб'єкта підприємницької діяльності щодо недопущення поширення інфекції шляхом дотримання карантинного режиму та інших заходів, а й участь правоохоронців у забезпеченні карантинної дисципліни.

Працівник правоохоронного органу, незважаючи на наявність повноважень щодо реалізації протиепідеміологічної правоохоронної компетенції, повинен реагувати на факти, які обумовлюють недотримання санітарно-епідеміологічних норм, які охоплюють склад адміністративного чи кримінального правопорушення.

Так, природа виконання правоохоронних повноважень у сфері охорони здоров'я та реалізації протиепідеміологічних заходів при COVID-19, зокрема, передбачає: необхідність прямого контакту із потенційними носіями вірусу; підвищений стресовий, конфліктний характер криміногенної обстановки, який зумовлений небажанням дотримуватися протиепідеміологічних заходів; збільшений обсяг робочого часу в результаті посилення оперативних чергувань; посилення загальної криміногенності у зв’язку із запровадженням карантинних заходів тощо.

Однією із позитивних законодавчих змін є впровадження регулярного тестування для працівників органів Національної поліції та Національної гвардії, яке згідно зі ст.35-1 вищезазначеного Закону здійснюється незалежно від того, чи мали вони встановлений контакт із особою, хворою на коронавірусну хворобу (COVID-19) [10].

\section{Висновки}

За результатами нормативно-правового аналізу роботи правоохоронних органів в умовах несприятливої епідеміологічної ситуації (на прикладі протидії гострій респіраторній хворобі COVID-19) виокремлено такі пропозиції:

1) з урахуванням наявного досвіду практичної реалізації підрозділами Національної гвардії України функцій забезпечення життєдіяльності населення та державних інституцій в умовах протидії COVID-19, з метою забезпечення правових гарантій їхньої законної діяльності, пропонується розробити Положення про участь підрозділів Національної гвардії України в забезпеченні життєдіяльності держави та населення в умовах поширення гострої респіраторної хвороби COVID-19. Пропонується виокремити такі заходи, до реалізації яких можуть залучатися військовослужбовці Національної гвардії України, як: охорона закладів обсервації; спільне з органами Національної поліції патрулювання вулиць, громадського транспорту на предмет дотримання карантинних обмежень; забезпечення безпеки медпрацівників та персоналу клінік, ліцензованих під лікування COVID-19, адміністративних та релігійних споруд; роз'яснення карантинних обмежень, спричинених COVID-19; контроль дотримання обмежень при в'їздах та виїздах з міст, селищ, пунк- 
тів обсервації, контроль пасажироперевезень; патрулювання публічних місць масового скупчення (вокзалів, парків, площ) з метою профілактики та контролю за дотримання санітарно-епідеміологічних обмежень; дезінфекція техніки, засобів протидії поширення інфекції; організація швидкої (екстреної) доставки медичних вантажів до пунктів призначення; гуманітарна допомога протидії поширенню COVID-19 на території іноземних держав у складі спільних груп;

2) у Розділі VIII Закону України «Про захист населення від інфекційних хвороб» працівники поліції не містяться серед суб'єктів, на яких поширюються заходи правового і соціального захисту медичних та інших працівників, зайнятих у сфері захисту населення від інфекційних хвороб. Зокрема, статтею 39 Закону України «Про захист населення від інфекційних хвороб» передбачено, що держава забезпечує страхові виплати медичним працівникам державних і комунальних закладів охорони здоров'я. Невключення в зазначений перелік працівників правоохоронних органів є суттєвим недоліком, який не забезпечує правоохоронцям достатніх гарантій їх професійної діяльності в умовах безпосередньої реалізації протиепідеміологічних повноважень.

Зурахуванням вищезазначеного пропонується внести зміни до абзацу другого статті 393 Закону України «Про захист населення від інфекційних хвороб» від 06.04.2000 № 1645-III, виклавши його в такій редакції: «Держава забезпечує страхові виплати в таких розмірах медичним працівникам державних і комунальних закладів охорони здоров'я, а також іншим працівникам органів державної влади, в тому числі правоохоронних органів»;

3) з метою підвищення професійної готовності правоохоронців щодо реалізації неспецифічних правозастосовних функцій існує необхідність розроблення внутрівідомчих інструкцій та проведення за їх результатами навчань. 3 урахуванням наявних складнощів пропонується забезпечити методологічну підтримку для працівників поліції:

- перелік та межі дії заборон, обмежень (з огляду на їх визначеність в різних нормативноправових актах);

- забезпечення безпеки, дотримання прав, свобод громадян та юридичних осіб в умовах COVID-19;

- підстави застосування заходів адміністративного припинення у справах про порушення карантинних обмежень;

- визначення меж суспільно небезпечних наслідків злочину, передбаченого ст. 325 КК України «Порушення санітарних правил і норм щодо запобігання інфекційним хворобам та масовим отруєнням» та його відмежуванням від адміністративного правопорушення, передбаченого ст. $44-^{3}$ Кодексу України про адміністративні правопорушення «Порушення правил щодо карантину людей».

\section{Використана література:}

1. Бухарєв, В.В., Рєзнік, О.М. Правовий режим самоізоляції. Сумський державний університет. Матеріали IV Міжнародної науково-практичної конференції. - Суми, 21-22 травня 2020 року. URL: https://essuir.sumdu.edu.ua/bitstream-download/123456789/77951/1/Bukharyev_isolation.pdf

2. Вознюк, А. Чернявський, С. Порушення правил і норм щодо запобігання COVID-19: актуальні проблеми кримінальної та адміністративної відповідальності. - Юридичний часопис Національної академії внутрішніх справ. 2020 №19.1. С: 8-19.

3. Кодекс цивільного захисту України : Кодекс України; Закон, Кодекс від 02.10.2012 № 5403-VI / База даних «Законодавство України» / Верховна Рада України. URL: https://zakon.rada.gov.ua/ go/5403-17 (дата звернення: 21.11.2021).

4. Колеснікова, М.В. Особливості та проблеми адміністративно-правового режиму пандемії COVID-19 в Україні - перспектива розвитку питання. Правові горизонти. 2021. Вип. 26 (39). С. $78-85$

5. Кримінальний кодекс України : Кодекс України; Кодекс, Закон від 05.04.2001 № 2341-III / База даних «Законодавство України» / Верховна Рада України. URL: https://zakon.rada.gov.ua/ go/2341-14 (дата звернення: 30.11.2021).

6. Логвиненко Б.О. Проблеми нормативно-правового забезпечення протидії covid-19 органами національної поліції: Дніпровський науковий часопис публічного управління, психології, права. 2020, № 2. URL: https://doi.org/10.51547/ppp.dp.ua/2020.2.8. 
7. Про визнання таким, що втратив чинність, наказу Міністерства охорони здоров'я України від 19.11.2002 № 420 : Наказ; МОЗ України від 18.01.2012 № 32 / База даних «Законодавство України» / Верховна Рада України. URL: https://zakon.rada.gov.ua/go/z0160-12 (дата звернення: 27.11.2021).

8. Про внесення змін до деяких законодавчих актів України, спрямованих на запобігання виникненню і поширенню коронавірусної хвороби (COVID-19) : Закон України від 17.03.2020 № 530-IX / База даних «Законодавство України» / Верховна Рада України. URL: https://zakon.rada.gov.ua/go/530-20 (дата звернення: 21.11.2021).

9. Про затвердження Положення про державну санітарно-епідеміологічну службу Міністерства охорони здоров'я України : Наказ; МОЗ України від 19.11.2002 № 420 // База даних «Законодавство України» / Верховна Рада України. URL: https://zakon.rada.gov.ua/go/z0960-02 (втратив чинність) (дата звернення: 15.11.2021).

10. Про захист населення від інфекційних хвороб : Закон України від 06.04.2000 № 1645-III / База даних «Законодавство України» / Верховна Рада України. URL: https://zakon.rada.gov.ua/ go/1645-14 (дата звернення: 29.11.2021).

11. Про правовий режим надзвичайного стану : Закон України від 16.03.2000 № 1550-III / База даних «Законодавство України» / Верховна Рада України. URL: https://zakon.rada.gov.ua/ go/1550-14 (дата звернення: 29.11.2021).

12. Редкоус, В.М. К вопросу об определении административно-правового режима обеспечения санитарно-эпидемиологического благополучия населения в связи с распространением новой коронавирусной инфекции COVID-19. Вестник Пермского института ФСИН России, 2020, № 2, С: 90-94.

13. Сокуренко, В.В. Правовий захист суб'єктів господарювання в умовах пандемії COVID-19. Актуальні питання діяльності суб'єктів господарювання в умовах пандемії COVID-19 : матеріали Міжнар. наук.-практ. конф. (м. Харків, 26 лют. 2021 р.) / МВС України, МОЗ України, Харків. нац. ун-т внутр. справ, Нац. фармацевт. ун-т. Харків : ХНУВС, 2021. С. 14-17.

\section{References:}

1. Bukhariev, V.V., Rieznik, O.M. (Sumy, 21-22 travnia 2020 roku). Pravovyi rezhym samoizoliatsii. Sumskyi derzhavnyi universytet [Legal regime of self-isolation]. Materialy IV Mizhnarodnoi naukovo-praktychnoi konferentsii. Retrieved from: https://essuir.sumdu.edu.ua/bitstreamdownload/123456789/77951/1/Bukharyev_isolation.pdf [in Ukrainian].

2. Vozniuk, A. Cherniavskyi, S. (2020). Porushennia pravyl i norm shchodo zapobihannia COVID-19: aktualni problemy kryminalnoi ta administratyvnoi vidpovidalnosti [Violation of COVID-19 prevention rules and regulations: current issues of criminal and administrative liability]. Yurydychnyi chasopys Natsionalnoi akademii vnutrishnikh sprav, 2020, №19.1. 8-19 [in Ukrainian].

3. Verkhovna Rada Ukrainy (2012). Kodeks tsyvilnoho zakhystu Ukrainy [Code of Civil Protection of Ukraine]: Kodeks Ukrainy; Zakon, Kodeks vid 02.10.2012 № 5403-VI// Baza danykh «Zakonodavstvo Ukrainy»/ Verkhovna Rada Ukrainy. Retrieved from: https://zakon.rada.gov.ua/go/5403-17 [in Ukrainian].

4. Kolesnikova, M.V (2021). Osoblyvosti ta problemy administratyvno-pravovoho rezhymu pandemii COVID-19 v Ukraini: perspektyva rozvytku pytannia [Features and problems of the administrative and legal regime of the COVID-19 pandemic in Ukraine - the prospect of the issue]. M.V. Kolesnikova, Ya.A. Shevtsov, N.S. Pak. Pravovi horyzonty, 2021, Vyp. 26 (39), 78-85 [in Ukrainian].

5. Verkhovna Rada Ukrainy (2001). Kryminalnyi kodeks Ukrainy [Criminal Code of Ukraine]: Kodeks Ukrainy; Kodeks, Zakon vid 05.04.2001 № 2341-III. Baza danykh «Zakonodavstvo Ukrainy». Verkhovna Rada Ukrainy. Retrieved from: https://zakon.rada.gov.ua/go/2341-14 [in Ukrainian].

6. Lohvynenko B.O. (2020). Problemy normatyvno-pravovoho zabezpechennia protydii COVID-19 orhanamy natsionalnoi politsii [Problems of normative and legal support of counteraction to COVID-19 by national police bodies] № 2. Dniprovskyi naukovyi chasopys publichnoho upravlinnia, psykholohii, prava. Retrieved from: https://doi.org/10.51547/ppp.dp.ua/2020.2.8 [in Ukrainian].

7. Verkhovna Rada Ukrainy (2012). Pro vyznannia takym, shcho vtratyv chynnist, nakazu Ministerstva okhorony zdorov `ia Ukrainy vid 19.11.2002 № 420 [On recognizing as invalid the order of the Ministry of Health of Ukraine dated 19.11.2002 № 420]: Nakaz. MOZ Ukrainy vid 18.01.2012 № 32. Baza danykh «Zakonodavstvo Ukrainy». Verkhovna Rada Ukrainy. Retrieved from: https://zakon.rada.gov. ua/go/z0160-12 [in Ukrainian]. 
8. Verkhovna Rada Ukrainy (2020). Pro vnesennia zmin do deiakykh zakonodavchykh aktiv Ukrainy, spriamovanykh na zapobihannia vynyknenniu i poshyrenniu koronavirusnoi khvoroby (COVID-19) [On Amendments to Certain Legislative Acts of Ukraine Aimed at Preventing the Occurrence and Spread of Coronavirus Disease (COVID-19)]. Zakon Ukrainy vid 17.03.2020 № 530-IX. Baza danykh «Zakonodavstvo Ukrainy». Verkhovna Rada Ukrainy. Retrieved from: https://zakon.rada.gov.ua/ go/530-20 [in Ukrainian].

9. MOZ Ukrainy (2002). Pro zatverdzhennia Polozhennia pro derzhavnu sanitarno-epidemiolohichnu sluzhbu Ministerstva okhorony zdorovia Ukrainy [About approval of the Situation on the state sanitary and epidemiological service of the Ministry of Health of Ukraine]. Nakaz, MOZ Ukrainy vid 19.11.2002 № 420. Baza danykh «Zakonodavstvo Ukrainy». Verkhovna Rada Ukrainy. Retrieved from: https://zakon.rada.gov.ua/go/z0960-02 (vtratyv chynnist) [in Ukrainian].

10. Verkhovna Rada Ukrainy (2000). Pro zakhyst naselennia vid infektsiinykh khvorob. [About protection of the population against infectious diseases]: Zakon Ukrainy vid 06.04.2000 № 1645-III. Baza danykh «Zakonodavstvo Ukrainy» / Verkhovna Rada Ukrainy. Retrieved from: https://zakon.rada.gov.ua/ go/1645-14 [in Ukrainian].

11. Verkhovna Rada Ukrainy (2000). Pro pravovyi rezhym nadzvychainoho stanu [About the legal regime of the state of emergency]: Zakon Ukrainy vid 16.03.2000 № 1550-III. Baza danykh «Zakonodavstvo Ukrainy». Verkhovna Rada Ukrainy. Retrieved from: https://zakon.rada.gov.ua/go/1550-14 [in Ukrainian].

12. Redkous, V.M. (2020). K voprosu ob opredelenyy admynystratyvno-pravovoho rezhyma obespechenyia sanytarno-эpydemyolohycheskoho blahopoluchyia naselenyia v sviazy s rasprostranenyem novoi koronavyrusnoi ynfektsyy COVID-19 [On the issue of determining the legal regime to ensure the sanitary and epidemiological well-being of the population in connection with the spread of a new coronavirus infection COVID-19], Vestnyk Permskoho instytuta FSYN Rossyy, 2020, №2, 90-94 [in Russian].

13. Sokurenko, V.V. (2021). Pravovyi zakhyst subiektiv hospodariuvannia v umovakh pandemii COVID-19 [Legal protection of business entities in the context of the COVID-19 pandemic]. Aktualni pytannia diialnosti subiektiv hospodariuvannia v umovakh pandemii COVID-19 : materialy Mizhnar. nauk.prakt. konf. (m. Kharkiv, 26 liut. 2021 r.), MVS Ukrainy, MOZ Ukrainy, Kharkiv, nats. un-t vnutr. sprav, Nats. farmatsevt. un-t. - Kharkiv : KhNUVS, 2021, 14-17 [in Ukrainian].

\section{Terekhov V. Yu. Legal regulation of law enforcement authorities activities in the conditions of an adverse epidemiological situation (on the example combating acute respiratory disease COVID-19)}

In thise article is analyzes the legal means of ensuring the guarantees of law enforcement in an unfavorable epidemiological situation (on the example of combating acute respiratory disease COVID-19 caused by coronavirus SARS-CoV-2) and introduced: to improve the legal regulation of the pandemic in a field of anti-epidemiological work by security and law enforcement agencies; to amend the legislation and departmental legal acts on medical care, insurance and financial assistance to employees and servicemen of law enforcement agencies that ensure compliance with quarantine discipline and life of the population for the period of quarantine; to differentiate between law enforcement and other functions in anti-epidemiological work, to determine areas of joint activity in order to counter the spread of COVID-19; to provide methodological and advisory supporting for police.

The purpose of legal means to ensure the guarantees of law enforcement is to ensure the safety, security and institutional capacity of security agencies, law and order in extreme conditions, in particular, in the spread of disease.

The involvement of law enforcement agencies in a pandemic should be considered in the following scenarios: the first is the use of administrative jurisdiction to identify and stop non-compliance with quarantine restrictions by compiling administrative materials and investigating crimes within the authority; second - strengthening law enforcement monitoring and control over the prevention, detection and cessation of illegal actions that are accompanied by a regime of quarantine restrictions (eg, domestic violence, cybercrime, vandalism, looting, hooliganism, etc.); third - strengthening the processes of security and law enforcement cooperation between the police, sanitary and epidemiological service, health and emergency services, border service, the National Guard, national security agencies, municipal guards, public associations to ensure the viability of the country in COVID-19.

Key words: COVID-19, unfavorable epidemiological situation, law enforcement agencies, cosial vital activity, epidemiological control. 
УДК 347.63

DOI https://doi.org/10.31392/NPU-nc.series 18.2021.36.11

Томляк Т. С.

\section{ГЕНЕЗИС ПРИНЦИПУ ЗАБЕЗПЕЧЕННЯ НАЙКРАЩИХ ІНТЕРЕСІВ ДИТИНИ В МІЖНАРОДНОМУ ПРАВІ}

Статтю присвячено генезису принцииу забезпечення найкращих інтересів дитини як основній правовій категорії, щз застосовується у сфері прав дитини. Проаналізовано норми міжнародного права у сфері захисту найкращих інтересів дитини. Зокрема, норми Конвенщії про права дитини та Факультативних протоколів до неї, Конвениії про иивільно-правові аспекти міжнародного викрадення дітей 1980 року, Конвениї про захист дітей та співробітництво в галузі міжнародного усиновлення 1993 року; Конвениії про юрисдикцію, застосовне право, визнання, виконання та співробітництво стосовно батьківської відповідальності та заходів захисту дітей 1996 року й низку інших. Виокремлено тенденції становлення принщипу забезпечення найкращих інтересів дитини.

Доведено, що вперше визначення «принщип правового забезпечення найкращих інтересів дитини» вжито в Конвениії про права дитини 1989 року, проте більше двадияти років в міжнародному та начіональному законодавстві відсутне визначення поняття «принципу правового забезпечення найкращих інтересів дитини». Зроблено висновок, щзо така прогалина в законодавстві призводить до правової невизначеності під час розгляду справ за участю дітей державними та судовими органами.

Визначено, що поняття «найкращі інтереси дитини» є ширшим, ніж поняття «права та свободи дитини». Запропоновано внести зміни до Закону України «Про охорону дитинства» та ввести поняття «принципу правого забезпечення найкращих інтересів дитини», а саме доповнити статтю 1 Закону Украӥни «Про охорону дитинства» абзацом 22 такого змісту: «принцип забезпечення найкращих інтересів дитини - це відображені у міжнародних договорах та закріплені в національному законодавстві основоположні засади та керівні ідеї, спрямовані на гармонійний розвиток дитини, забезпечення її потреб та інтересів, як ширшого поняття, ніж права та свободи дитини, з урахуванням винятковості та особливості кожної дитини».

Ключові слова: дитина, права, генезис, принцип, найкращі інтереси, сімейні відносини, батьки.

Постановка проблеми. Принцип забезпечення найкращих інтересів дитини $є$ пріоритетним і визначальним у відносинах за участю дітей. Він лежить в основі ефективного механізму забезпечення прав і свобод дитини. Категорія «принцип забезпечення найкращих інтересів дитини» надає можливість забезпечити реалізацію тих інтересів дитини, які не охоплюються правом. Зокрема, закріплене в законодавстві пріоритетне право дитини на сімейне виховання не гарантує дитині права на щасливу сім'ю. Зважаючи на це, вивчення сутності та генезису цього принципу в міжнародному та національному праві є досить актуальним.

Аналіз останніх досліджень і публікацій. Серед науковців принципи правового захисту прав дитини досліджували такі науковці, як Б. Андрусишин [1, 2], Н. Оніщенко [3], Н. Опольська $[4,5,6]$, Ю. Шемшученко [7]. Поряд із цим питання найкращих інтересів дитини розглядалося такими вченими, як М. Менджул [8], Ж. Петрочко [9], Я. Тудольцева [10] та інші.

Формулювання цілей статті. Метою статті є вивчення сутності та генезису принципу забезпечення найкращих інтересів дитини в міжнародному праві та національному законодавстві.

Виклад основного матеріалу дослідження. Нині принцип забезпечення найкращих інтересів дитини є основним у будь-яких відносинах за участю дітей. Проте на практиці захист прав, свобод дитини не завжди зорієнтований на вказаний принцип.

Головним чинником регулювання відносин захисту прав, свобод та інтересів дитини є міжнародно-правові акти в галузі захисту прав дітей. До таких документів належать міжнародні договори, резолюції міжнародних організацій, до яких належать: Організація Об'єднаних Націй, Міжнародна організація праці, дитячий фонд OOH-UNICEF; Всесвітня організація охорони здоров'я; комітет ООН у справах освіти, науки і культури. Прийняття міжнародних дого- 
ворів щодо захисту прав дітей не було раптовим, а стало наслідком багаторічного розвитку правового захисту прав та свобод дитини.

Передусім необхідність захисту прав дитини було зумовлено тим, що з розвитком суспільства діти на рівні з дорослими почали брати участь у правовідносинах. Насамперед до таких відносин належали трудові, які полягали саме у фізичній праці малолітніх дітей на заводах чи фабриках країн Свропи та Америки в XIX столітті.

При цьому незахищеність дітей використовували як роботодавці, так і батьки дітей, адже дитиною, яка не досягнула фізичної і психологічної зрілості, легше керувати і примушувати до чогось, надавати меншу заробітну плату за виконану роботу.

Звичайно, така робота неповнолітніх дітей негативно впливала на їх здоров’я, фізичний, психічний та соціальний розвиток та позбавляла можливості навчатися.

3 метою захисту прав та інтересів дітей Генеральна конференція Міжнародної організації праці 29 жовтня 1919 року прийняла Конвенцію про мінімальний вік приймання дітей на роботу в промисловості № 5, якою передбачила, що діти, молодші за чотирнадцять років, не приймаються на роботу і не виконують роботи на жодному з державних або приватних промислових підприємств [11].

Прийняття Конвенції про мінімальний вік значно посилило захист прав дітей, оскільки на практиці праця дітей використовувалася без врахування забезпечення потреб дитини.

У подальшому ще однією підставою необхідності вирішення питання щодо захисту прав і свобод дитини стали Перша та Друга світові війни. Так, внаслідок Першої світової війни велика кількість дітей залишилася без батьківського піклування, житла, їжі та інших життєво важливих речей.

Першим кроком на міжнародному рівні, після якого права дитини увійшли до системи міжнародного права, було прийняття Лігою Націй 1924 року Женевської декларації про права дитини, яка складається всього з п'яти пунктів. У зазначених пунктах ми вбачаємо першу спробу узагальнення найкращих інтересів дитини:

1. Дитина має отримувати усі засоби, необхідні для іiі нормального матеріального і духовного розвитку.

2. Голодна дитина має бути нагодована; хвора дитина має бути доглянута; дитина у скруті має отримати допомогу; сирота або безпритульна дитина має отримати притулок і догляд.

3. У лихі часи дитина першою має отримати допомогу.

4. Дитина повинна мати засоби для існування і захист від будь-яких форм експлуатації.

5. Дитина має бути вихована з усвідомленням того, що їі кращі якості повинні служити іншим людям [12].

Як вказано в преамбулі Декларації прав дитини 1959 року, саме Женевська декларація прав дитини 1924 р. заклала основи захисту прав дітей [13].

У подальшому з метою захисту прав дітей у 1946 році, після завершення Другої світової війни, було засновано Міжнародний надзвичайний фонд допомоги дітям при Організації Об'єднаних Націй. Основною метою фонду було допомагати дітям, життя яких було в небезпеці та захистити їхні права.

Через два роки, в 1948 році, Генеральною Асамблеєю була прийнята Загальна декларація прав людини [13]. В iї положеннях, а саме статті 25, вказано, що материнство і дитинство дають право на особливе піклування і допомогу. Всі діти, народжені у шлюбі або поза шлюбом, повинні користуватися однаковим соціальним захистом [13, ст. 25].

Подальший розвиток найкращих інтересів дитини знайшов своє відображення у Декларації прав дитини, що була прийнята Генеральною Асамблеєю ООН у 1959 році, в якій були сформульовані десять принципів, що визначають дії всіх, хто відповідає за здійснення всієї повноти прав дітей, і яка мала на меті забезпечення їм «щасливого дитинства» [14].

В основі сучасного принципу забезпечення найкращих інтересів дитини лежить Конвенція про права дитини.

Під час створення Конвенції про права дитини було взято до уваги напрацювання, зафіксовані в Женевській декларації прав дитини 1924 року [11] і Декларації прав дитини, прийнятій 
Генеральною Асамблеєю 20 листопада 1959 року [13], Загальній декларації прав людини [14], в Міжнародному пакті про громадянські і політичні права (зокрема, у статтях 23 і 24) [15], в Міжнародному пакті про економічні, соціальні і культурні права (зокрема, в статті 10) [16], а також у статутах і відповідних документах спеціалізованих установ і міжнародних організацій, що займаються питаннями благополуччя дітей.

Отже, вперше було узагальнено інтереси дитини в Женевській декларації прав дитини 1924 р. Вперше вжито визначення «принцип правового забезпечення найкращих інтересів дитини» в Конвенції про права дитини 1989 року [17]. Україна ратифікувала Конвенцію про права дитини 27 лютого 1991 року відповідно до Постанови Верховної ради Української РСР № 789-XII [18].

У Конвенції про права дитини вперше було проголошено на міжнародному рівні принцип якнайкращого забезпечення інтересів дитини в усіх діях щодо дітей, проте більше двадцяти років в міжнародному та національному законодавстві відсутнє визначення поняття «принципу правового забезпечення найкращих інтересів дитини».

Так, Конвенція про права дитини є юридичною базою існування та функціонування Комітету з прав дитини, що здійснює контроль за виконанням державами-учасницями своїх зобов'язань за цим міжнародним договором та факультативними протоколами до нього.

На підставі Конвенції про права дитини було прийнято три факультативних протоколи до неї:

1. Факультативний протокол до Конвенції про права дитини щодо торгівлі дітьми, дитячої проституції і дитячої порнографії від 25 травня 2000 року [19];

2. Факультативний протокол до Конвенції про права дитини щодо участі дітей у збройних конфліктах від 25 травня 2000 року [20];

3. Факультативний протокол до Конвенції про права дитини щодо процедури повідомлень від 19 грудня 2011 року [21].

Частина 3 статті 8 Факультативного протоколу до Конвенції про права дитини щодо торгівлі дітьми, дитячої проституції і дитячої порнографії від 25 травня 2000 року визначає, що держави-учасниці забезпечують, щоб у системі кримінального судочинства при поводженні з дітьми, які є жертвами злочинів, передбачених цим Протоколом, першочергова увага приділялась дотриманню найкращих інтересів дитини.

Також цей протокол зобов'язує держав-учасниць криміналізувати на національному рівні протиправні діяння щодо дітей, передбачити кримінальну відповідальність за їх вчинення та вживати на рівні держави відповідних заходів для захисту прав та інтересів дітей.

Зокрема, відповідно до частини 3 статті 8 Факультативного протоколу до Конвенції про права дитини щодо торгівлі дітьми, дитячої проституції і дитячої порнографії від 25 травня 2000 року держави-учасниці вживають відповідних заходів для захисту прав та інтересів дітей-жертв практики, забороненої цим Протоколом, на всіх етапах кримінального судочинства, зокрема шляхом: а) визнання уразливості дітей-жертв і адаптації процедур для визнання їхніх особливих потреб, у тому числі їх особливих потреб як свідків; b) інформування дітей-жертв про їхні права, роль та утримання, терміни і процес судочинства та про рішення щодо їхніх справ; c) забезпечення того, щоб думки, потреби і проблеми дітей жертв подавались і розглядались у процесі судочинства відповідно до процесуальних норм національного законодавства у тих випадках, коли зачіпаються їхні особисті інтереси; d) надання дітям-жертвам послуг щодо надання відповідної підтримки на всіх етапах судочинства; е) захисту у відповідних випадках особистого життя й особи дітей-жертв та вжиття заходів, згідно з національним законодавством, із метою уникнення небажаного розповсюдження інформації, яка могла би призвести до встановлення особи дітей-жертв; f) забезпечення у відповідних випадках захисту дітей-жертв, а також їхніх сімей та свідків, які виступають від їхнього імені, від залякування та застосування заходів помсти; g) недопущення надмірних затримок із винесенням рішень щодо справ та виконанням розпоряджень і постанов щодо надання компенсації дітям-жертвам [19, ст. 8].

Отже, цей Протокол із метою дотримання найкращих інтересів дитини зобов'язує державучасниць передбачити в національному законодавстві та реалізувати на практиці проведення 
слідчих дій у межах кримінального провадження та здійснити судовий розгляд справ щодо торгівлі дітьми, дитячої проституції і дитячої порнографії, адаптувавши усі процери під особливості дитини, забезпечити конфіденційність та швидкість проведення як слідчих дій, так і судового розгляду такої категорії справ. Реалізація проведення вказаних дій повинна зебезпечувати дотримання найкращих інтересів дитини.

Проте, як свідчить практика, національні державні органи під час розгляду справ за участю дітей в межах кримінального аспекту часто вдаються до надмірного формалізму, дитяча спеціалізація як слідчих, так і судових органів здебільшого не передбачає спеціальної підготовки, органи кримінальної юстиції не адаптовані до роботи з дітьми, недостатньо психологів та соціальних педагогів, які підготовлені до роботи з дітьми у контакті із законом, що призводить до порушення найкращих інтересів дітей.

Положення Факультативного протоколу до Конвенції про права дитини щодо участі дітей у збройних конфліктах від 25 травня 2000 року є особливо актуальними для нашої держави під час війни з Російською Федерацією. Зокрема, цей протокол проголошує, що держави-учасниці, будучи впевнені, що факультативний протокол до Конвенції, який підвищує вік можливого призову осіб до збройних сил і їхньої участі у військових діях, ефективно сприятиме здійсненню принципу, згідно з яким у всіх діях щодо дітей першочергова увага повинна приділятися найкращому забезпеченню інтересів дитини [20].

Стаття 3 цього ж факультативного протоколу передбачає, що держави-учасниці підвищують мінімальний вік добровільного призову осіб до їхніх національних збройних сил порівняно 3 віком, визначеним у пункті 3 статті 38 Конвенції про права дитини, враховуючи принципи, які містяться в цій статті, і визнаючи, що відповідно до Конвенції особи, які не досягли 18 років, мають право на особливий захист [20, ст. 3].

Вважаємо, що до такого особливого захисту належать не лише наявність національного законодавства, яке захищало би права та свободи неповнолітніх під час збройних конфліктів, а й практична реалізація забезпечення прав та свобод дітей під час воєнних дій.

Факультативний протокол до Конвенції про права дитини щодо процедури повідомлень від 19 грудня 2011 року збільшив коло повноважень Комітету із прав дитини шляхом проведення процедур повідомлень і розслідувань.

Поряд із цим статтею 2 Факультативного протоколу до Конвенції про права дитини щодо процедури повідомлень від 19 грудня 2011 року передбачено, що під час виконання функцій, покладених на нього цим Протоколом, Комітет керується принципом найкращого забезпечення інтересів дитини. Він також враховує права й погляди дитини, приділяючи поглядам дитини належну увагу відповідно до віку та зрілості дитини [21, ст. 2].

Нашою державою під час ратифікації Факультативного протоколу до Конвенції про права дитини щодо процедури повідомлень заявлено про тимчасову об'єктивну неможливість виконання своїх зобов'язань за вказаним протоколом на тимчасово окупованій території України, а також в окремих районах Донецької та Луганської областей України.

Комітет із прав дитини виконує моніторингову функцію. Як зазначено статтею 43 Конвенції про права дитини, метою діяльності цього органу є розгляд прогресу, досягнутого державамиучасницями щодо виконання зобов'язань, взятих згідно з цим міжнародним договором. Комітет складається з 18 експертів, які виступають в особистій якості та обираються на чотирирічних строк із можливістю переобрання [17, ст. 43].

Поряд 3 цим стаття 44 Конвенції про права дитини передбачає, що держави-учасниці зобов'язані подавати Комітету через Генерального секретаря Організації Об'єднаних Націй доповіді про вжиті ними заходи щодо закріплення визнаних у Конвенції прав та прогрес, досягнутий у здійсненні цих прав: а) протягом двох років після набуття чинності цією Конвенцією для відповідної Держави-учасниці; b) надалі - кожні п'ять років. У доповідях, які подаються відповідно до цієї статті, зазначаються фактори і труднощі, якщо такі є, що впливають на ступінь виконання зобов'язань за цією Конвенцією. Доповіді містять також достатню інформацію, щоб забезпечити Комітету повне розуміння дії Конвенції у цій країні. Державі-учасниці, яка подала Комітету всебічну первинну інформацію, немає необхідності повторювати у наступних 
доповідях, що подаються відповідно до пункту 1 підпункту b цієї статті, раніше викладену основну інформацію. Комітет може запитувати у Держав-учасниць додаткову інформацію, що стосується здійснення цієї Конвенції. Держави-учасниці забезпечують широку гласність своїм доповідям у власних країнах [17, ст. 44].

Комітет із прав дитини після розгляду доповідей може вносити рекомендації та пропозиції загального характеру, які направляються будь-якій зацікавленій державі-учасниці і повідомляються Генеральній Асамблеї ООН поряд із зауваженнями держав-учасниць, якщо такі є. Такі зауваження Комітету із прав дитини можуть бути використані у національних судах України через призму пункту 11 постанови Пленуму Вищого спеціалізованого суду України з розгляду цивільних і кримінальних справ від 19 грудня 2014 року №13 «Про застосування судами міжнародних договорів України при здійсненні правосуддя», яким передбачено, що у разі виникнення труднощів із застосуванням міжнародних договорів України суди при здійсненні правосуддя можуть використовувати акти та рішення міжнародних організацій, спеціалізованих органів, які мають повноваження щодо тлумачення відповідних міжнародних договорів або врегулювання спорів щодо тлумачення [22].

Конвенція про права дитини та факультативні протоколи до неї є міжнародними договорами у значенні п.П. «а» п.1 ст.2 Віденської конвенції про право міжнародних договорів, відповідно до якого «договір» означає міжнародну угоду, укладену між державами в письмовій формі і регульовану міжнародним правом, незалежно від того, чи викладена така угода в одному документі, двох чи кількох зв'язаних між собою документах, а також незалежно від іiї конкретного найменування [23, ст. 2].

Окрім Конвенції про права дитини та Факультативних протоколів до неї, забезпечення найкращих інтересів дитини знайшло своє відображення у Конвенції про захист прав людини й основоположних свобод 1950 року [24], Конвенції про цивільно-правові аспекти міжнародного викрадення дітей 1980 року [25]; Конвенції про захист дітей та співробітництво в галузі міжнародного усиновлення 1993 року [26]; Конвенції про юрисдикцію, застосовне право, визнання, виконання та співробітництво стосовно батьківської відповідальності та заходів захисту дітей 1996 року [27] й низці інших. При цьому жодний із вищезазначених міжнародних документів не містить визначення поняття та змісту принципу правового забезпечення найкращих інтересів дитини.

Стеттею 6 Конвенції про захист прав людини й основоположних свобод 1950 року передбачено, що судове рішення проголошується публічно, але преса і публіка можуть бути не допущені в зал засідань протягом усього судового розгляду або його частини в інтересах моралі, громадського порядку чи національної безпеки в демократичному суспільстві, якщо того вимагають інтереси неповнолітніх [24].

Так, у Конвенції про цивільно-правові аспекти міжнародного викрадення дітей 1980 року закріплено, що держави, що підписали цю Конвенцію, твердо переконані в тому, що інтереси дітей - це найважливіше в справі турботи про них [25].

Стаття 4 Конвенції про захист дітей та співробітництво в галузі міжнародного усиновлення 1993 року передбачає, що усиновлення в межах цієї Конвенції має місце тільки у випадку, якщо компетентні органи влади Держави походження визначили після належного розгляду можливостей улаштування дитини в Державі походження, що міждержавне усиновлення відповідає найкращим інтересам дитини [26, ст. 4].

Відповідно до Конвенції про юрисдикцію, застосовне право, визнання, виконання та співробітництво стосовно батьківської відповідальності та заходів захисту дітей 1996 року держави, що підписали цю Конвенцію, підтверджують, що найвищим інтересам дитини повинне надаватися першочергове значення. Так, статтею 28 вказаної Конвенції визначено, що заходи, ужиті в одній Договірній Державі та визнані такими, що підлягають виконанню або реєстрації 3 метою виконання в іншій Договірній Державі, виконуються в останній Державі так, якби вони були вжиті органами тієї Держави. Виконання відбувається згідно з правом держави, в якій було подано прохання, настільки, наскільки передбачено цим правом, беручи до уваги найвищі інтереси дитини [27, ст. 28]. 
Вважаємо, що принцип забезпечення найкращих інтересів дитини - це відображені у міжнародних договорах та закріплені в національному законодавстві основоположні засади та керівні ідеї, спрямовані на гармонійний розвиток, забезпечення ii потреб та інтересів, як ширшого поняття, ніж права дитини, з урахуванням винятковості та особливості кожної дитини.

Тобто найкращі інтереси дитини є ширшим поняттям за права та свободи дитини, закріплені в праві. У зв'язку з цим пропонуємо внести зміни до Закону України «Про охорону дитинства» та ввести поняття «принципу правого забезпечення найкращих інтересів дитини», а саме доповнити статтю 1 Закону України «Про охорону дитинства» абзацом 22 такого змісту: «Принцип забезпечення найкращих інтересів дитини - це відображені у міжнародних договорах та закріплені в національному законодавстві основоположні засади та керівні ідеї, спрямовані на гармонійний розвиток, забезпечення її потреб та інтересів, як ширшого поняття, ніж права дитини, з урахуванням винятковості та особливості кожної дитини».

Для визначення аспектів, які можна буде враховувати при розгляді справи за участю дитини для врахування іiї найкращих інтересів, автор вважає за необхідне продовжити вивчення міжнародного та національного законодавства, а також проаналізувати практику Європейського суду з прав людини та національних судів.

Висновки. Підсумовуючи викладене, слід зазначити, що вперше принцип забезпечення найкращих інтересів дитини було проголошено Конвенцією про права дитини 1989 року. Проте вже більше двадцяти років в міжнародному і в національному законодавстві відсутнє визначення та поняття змісту принципу правового забезпечення найкращих інтересів дитини. Така прогалина в законодавстві призводить до правової невизначеності при розгляді справ за участю дітей державними та судовими органами.

Автором запропоновано закріпити на законодавчому рівні визначення принципу правого забезпечення найкращих інтересів дитини та аспекти, які можна буде враховувати під час розгляду справи за участю дитини для врахування iї найкращих інтересів.

\section{Використана література:}

1. Б. Андрусишин, С. Шимон. Науково-практична підготовка правознавців у сфері прав дитини в НПУ імені М.П. Драгоманова. Юридичний журнал. 2013. № 2. с. 37-42.

2. Соціально-правовий захист дітей в Україні: монографія/за ред. Б.І. Андрусишина. - К. : Видавництво НПУ імені М. П. Драгоманова, 2017. - 264с.

3. Н. Оніщенко, О. Львова, С. Сунєгін. Права і свободи дитини: вступ до проблеми Лаврик Г.В. Людиномірність політики сприяння розвитку кооперації. Часопис Київського університету права. 2013. №2. с. 13-17.

4. Н. Опольська. Принципи правового захисту дитини. Держава і право. 2011. № 51. с. 40-45.

5. Н. Опольська. Права дитини в Україні: монографія, 2-ге видання, перероблене та доповнене. Вінниця: ВНАУ. 2019. с. 289.

6. Н. Опольська. Теоретико-правові засади забезпечення прав і свобод дитини: монографія. Вінниця: ПП «Едельвейс і К», 2011. с. 226.

7. Актуальні проблеми юридичної освіти та науки в Україні: монографія / за ред. Ю.С. Шемшученка. Київ. Вид-во НПУ імені М.П. Драгоманова. 2016 р. с. 322-344.

8. М. Менджул Зміст принципу найкращих інтересів дитини та його практичне застосування. Науковий вісник Ужгородського національного університету. Серія Право. 2019. Випуск 56. Том 1. с. 87-91.

9. Ж Петрочко. Найкращі інтереси дитини: сутність і шляхи забезпечення. Наукові записки НДУ ім. М. Гоголя. 2014. с. 70-74.

10. Я. Тубольцева. Забезпечення найкращих інтересів дитини при розгляді судом справ про усиновлення. Теорія і практика правознавства. 2018.2 (14). с. 1-14.

11. Конвенція про мінімальний вік приймання дітей на роботу в промисловості № 5 від 29.10.1919 року. URL: https://zakon.rada.gov.ua/laws/show/993_109\#Text.

12. Женевська декларація прав дитини 1924 p. URL: http:/www.un-documents.net/gdrc1924.htm.

13. Загальна декларація прав людини, прийнята і проголошена резолюцією 217 A (III) Генеральної Асамблеї ООН від 10 грудня 1948 року. URL: https://zakon.rada.gov.ua/laws/show/995_015\#Text. 
14. Декларація прав дитини, прийнята резолюцією 1386 (XIV) Генеральної Асамблеї ООН від 20 листопада 1959 року. URL: https://zakon.rada.gov.ua/laws/show/995 384\#Text.

15. Міжнародний пакт про громадянські і політичні права від 16.12 .1966 року. URL: https://zakon.rada.gov.ua/laws/show/995_043\#Text

16. Міжнародний пакт про економічні, соціальні і культурні права від 16.12.1966 року. URL: https://zakon.rada.gov.ua/laws/show/995_042\#Text.

17. Конвенція про права дитини, прийнята Генеральною Асамблеєю ООН 20 листопада 1989 року. URL: https://zakon.rada.gov.ua/laws/show/995_021\#Text.

18. Про ратифікацію Конвенції про права дитини: Постанова Верховної ради Української РСР від 27 лютого 1991 року № 789-XII. URL: https://zakon.rada.gov.ua/laws/show/789-12\#Text.

19. Факультативний протокол до Конвенції про права дитини щодо торгівлі дітьми, дитячої проституції і дитячої порнографії від 25 травня 2000 року. URL: https://zakon.rada.gov.ua/laws/ show/995 b09\#Text

20. Факультативний протокол до Конвенції про права дитини щодо участі дітей у збройних конфліктах від 25 травня 2000 року. URL: https://zakon.rada.gov.ua/laws/show/995_795\#Text

21. Факультативний протокол до Конвенції про права дитини щодо процедурй повідомлень від 19 грудня 2011 року. URL: https://zakon.rada.gov.ua/laws/show/995_160\#Text

22. Постанова Пленуму Вищого спеціалізованого суду України з розгляду цивільних і кримінальних справ від 19 грудня 2014 року №13 «Про застосування судами міжнародних договорів України при здійсненні правосуддя». URL: https://zakon.rada.gov.ua/laws/show/v0013740-14\#Text

23. Віденська конвенція про право міжнародних договорів від 23.05.1969 року. URL: https://zakon.rada.gov.ua/laws/show/995_118\#Text.

24. Конвенція про захист прав людини і основоположних свобод від 04.11.1950 року. URL: https://zakon.rada.gov.ua/laws/show/995_004\#Text.

25. Конвенція про цивільно-правові аспекти міжнародного викрадення дітей від 25 жовтня 1980 року. URL: https://zakon.rada.gov.ua/laws/show/995_188\#Text.

26. Конвенція про захист дітей та співробітництво в галузі міжнародного усиновлення від 29 травня 1993 року. URL: https://zakon.rada.gov.ua/laws/show/995_365\#Text.

27. Конвенція про юрисдикцію, застосовне право, визнання, виконання та співробітництво стосовно батьківської відповідальності та заходів захисту дітей 19 жовтня 1996 року. URL: https://zakon.rada.gov.ua/laws/show/973_002\#Text.

\section{References:}

1. B. Andrusyshyn, S. Shymon (2013). Naukovo-praktychna pidhotovka pravoznavtsiv u sferi prav dytyny v NPU imeni M.P. Drahomanova. [Scientific and practical training of jurists in the field of children's rights at NPU named after MP Драгоманова]. Yurydychnyy zhurnal - Legal journal, 2, 37-42 [in Ukrainian].

2. B. Andrusyshyn. Sotsial'no-pravovyy zakhyst ditey v Ukrayini [Social and legal protection of children in Ukraine]. Vydavnytstvo NPU imeni M. P. Drahomanova -

1. MP Drahomanov National Pedagogical University Publishing House, 2017, 264.

3. N. Onishchenko, O. L'vova, S. Sunyehin (2013). Prava i svobody dytyny: vctup do problemy Lavryk HV Lyudynomirnist' polityky spryyannya rozvytku kooperatsiyi. [Rights and freedoms of the child: an introduction to the problem Lavrik GV Humanity of the policy of promoting the development of cooperation]. Chasopys Kyyivs'koho universytetu prava - Journal of Kyiv University of Law, 2, 13-17 [in Ukrainian].

4. N. Opol's'ka. (2011). Pryntsypy pravovoho zakhystu dytyny. [Principles of legal protection of the child]. Derzhava i pravo - State and law, 51, 40-45 [in Ukrainian].

5. N. Opol's'ka. Prava dytyny v Ukrayini: monohrafiya, 2-he vydannya, pereroblene ta dopovnene. [Children's rights in Ukraine: monograph, 2nd edition, revised and supplemented]. Vinnyts'kyy natsional'nyy ahrarnyy universytet - Vinnytsia National Agrarian University, 2019, 289.

6. N. Opol's'ka. Teoretyko-pravovi zasady zabezpechennya prav i svobod dytyny: monohrafiya. [Theoretical and legal principles of ensuring the rights and freedoms of the child: a monograph]. PP «Edel'veys i K» - PE "Edelweiss and K", 2011, 226.

7. YU. Shemshuchenko. Aktual'ni problemy yurydychnoyi osvity ta nauky v Ukrayini: monohrafiya. [Current problems of legal education and science in Ukraine: a monograph]. ]. Vydavnytstvo NPU imeni M. P. Drahomanova - MP Drahomanov National Pedagogical University Publishing House, 2016 p, 322-344. 
8. M. Mendzhul. (2019). Zmist pryntsypu naykrashchykh interesiv dytyny ta yoho praktychne zastosuvannya. [The content of the principle of the best interests of the child and its practical application]. Naukovyy visnyk Uzhhorods'koho natsional'noho universytetu. Seriya Pravo. - Scientific Bulletin of Uzhhorod National University. Law Series, 56, 87-91 [in Ukrainian].

9. ZH Petrochko. (2014) Naykrashchi interesy dytyny: sutnist' i shlyakhy zabezpechennya. [The best interests of the child: the essence and ways to ensure]. Naukovi zapysky NDU im. M. Hoholya - Scientific notes of NDU named after M. Gogol, 70-74 [in Ukrainian].

10. YA. Tubol'tseva. Zabezpechennya naykrashchykh interesiv dytyny pry roz hlyadi sudom sprav pro usynovlennya. [Ensuring the best interests of the child when the court considers adoption cases]. Teoriya i praktyka pravoznavstva - Theory and practice of jurisprudence, 2 (14), 1-14 [in Ukrainian].

11. Konventsiya pro minimal'nyy vik pryymannya ditey na robotu v promyslovosti № 5 vid 29.10.1919 roku. [Convention concerning the Minimum Age for Admission of Children to Work in Industry № 5 of 29.10.1919]. Retrieved from: https://zakon.rada.gov.ua/laws/show/993_109\#Text. [in Ukrainian].

12. Zhenevs'ka deklaratsiya prav dytyny $1924 \mathrm{r}$. [Geneva Declaration of the Rights of the Child 1924]. Retrieved from: http://www.un-documents.net/ gdrc1924.htm. [in Ukrainian].

13. Zahal'na deklaratsiya prav lyudyny, pryynyata i proholoshena rezolyutsiyeyu 217 A (III) Heneral'noyi Asambleyi OON vid 10 hrudnya 1948 roku. [Universal Declaration of Human Rights, adopted and promulgated by UN General Assembly Resolution 217 A (III) of 10 December 1948]. Retrieved from: https://zakon.rada.gov.ua/laws/show/995_015\#Text. [in Ukrainian].

14. Deklaratsiya prav dytyny, pryynyata rezolyutsiyeyu 1386 (KHIV) Heneral'noyi Asambleyi OON vid 20 lystopada 1959 roku. [Declaration of the Rights of the Child, adopted by UN General Assembly Resolution 1386 (XIV) of 20 November 1959]. Retrieved from: https://zakon.rada.gov.ua/laws/ show/995_384\#Text. [in Ukrainian].

15. Mizhnarōnnyy pakt pro hromadyans'ki i politychni prava vid 16.12.1966 roku [International Covenant on Civil and Political Rights of December 16, 1966]. Retrieved from: https://zakon.rada.gov.ua/laws/ show/995_043\#Text. [in Ukrainian].

16. Mizhnarō̄nyy pakt pro ekonomichni, sotsial'ni i kul'turni prava vid 16.12.1966 roku. [International Covenant on Economic, Social and Cultural Rights of December 16, 1966]. Retrieved from: https://zakon.rada.gov.ua/laws/show/995_042\# Text. [in Ukrainian].

17. Konventsiya pro prava dytyny, pryynyata Heneral'noyu Asambleyeyu OON 20 lystopada 1989 roku. [Convention on the Rights of the Child, adopted by the UN General Assembly on November 20, 1989]. Retrieved from: https://zakon.rada.gov.ua/laws /show/995_021\#Text. [in Ukrainian].

18. Pro ratyfikatsiyu Konventsiyi pro prava dytyny [On ratification of the Convention on the Rights of the Child] Resolution of the Verkhovna Rada of the Ukrainian SSR (1991, february 27) № 789-XII. Retrieved from: https://zakon.rada.gov.ua/laws/show/789-12\#Text. [in Ukrainian].

19. Fakul'tatyvnyy protokol do Konventsiyi pro prava dytyny shchodo torhivli dit'my, dytyachoyi prostytutsiyi i dytyachoyi pornohrafiyi vid 25 travnya 2000 roku. [Optional Protocol to the Convention on the Rights of the Child on the sale of children, child prostitution and child pornography of 25 May 2000]. Retrieved from: https://zakon.rada.gov.ua/laws/show/995_b09\#Text. [in Ukrainian].

20. Fakul'tatyvnyy protokol do Konventsiyi pro prava dytyny shchodo uchasti ditey u zbroynykh konfliktakh vid 25 travnya 2000 roku. [Optional Protocol to the Convention on the Rights of the Child on the Involvement of Children in Armed Conflict of 25 May 2000]. Retrieved from: https://zakon.rada.gov.ua/laws/show/995_795\#Text. [in Ukrainian].

21. Fakul'tatyvnyy protokol do Konventsiyi pro prava dytyny shchodo protsedury povidomlen' vid 19 hrudnya 2011 roku [Optional Protocol to the Convention on the Rights of the Child on the notification procedure of 19 December 2011]. Retrieved from: https://zakon.rada.gov.ua/laws/show/995_160\#Text. [in Ukrainian].

22. Postanova Plenumu Vyshchoho spetsializovanoho sudu Ukrayiny z roz'hlyadu tsyvil'nykh i kryminal'nykh sprav vid 19 hrudnya 2014 roku №13 «Pro zastosuvannya sudamy mizhnarodnykh dohovoriv Ukrayiny pry zdiysnenni pravosuddya». [Resolution of the Plenum of the Supreme Specialized Court of Ukraine for Civil and Criminal Cases of December 19, 2014 №13 "On the application by courts of international treaties of Ukraine in the administration of justice."] Retrieved from: https://zakon.rada.gov.ua/laws/show/v0013740-14\#Text. [in Ukrainian].

23. Videns'ka konventsiya pro pravo mizhnarodnykh dohovoriv vid 23.05.1969 roku. [Vienna Convention on the Law of Treaties of 23 May 1969]. Retrieved from: https://zakon.rada.gov.ua/laws/ show/995_118\#Text. [in Ukrainian]. 
24. Konventsiya pro zakhyst prav lyudyny i osnovopolozhnykh svobod vid 04.11.1950 roku. [Convention for the Protection of Human Rights and Fundamental Freedoms November 4, 1950]. Retrieved from: https://zakon.rada.gov.ua/laws/ show/995_004\#Text. [in Ukrainian].

25. Konventsiya pro tsyvil'no-pravovi aspekty mizhnarodnoho vykradennya ditey vid 25 zhovtnya 1980 roku. [Convention on the Civil Aspects of International Child Abduction, October 25, 1980]. Retrieved from: https://zakon.rada.gov.ua/laws/show/9 95_188\#Text. [in Ukrainian].

26. Konventsiya pro zakhyst ditey ta spivrobitnytstvo v haluzi mizhnarodnoho usynovlennya vid 29 travnya 1993 roku. [Convention on the Protection of Children and Co-operation in Respect of Intercountry Adoption, May 29, 1993]. Retrieved from: https://zakon.rada.gov.ua/laws/show/995_365\#Text. [in Ukrainian].

27. Konventsiya pro yurysdyktsiyu, zastosovne pravo, vyznannya, vykonannya ta spivrobitnytstvo stosovno bat'kivs'koyi vidpovidal'nosti ta zakhodiv zakhystu ditey 19 zhovtnya 1996 roku [Convention on Jurisdiction, Applicable Law, Recognition, Enforcement and Cooperation in Respect of Parental Responsibility and Measures for the Protection of Children 19 October 1996]. Retrieved from: https://zakon.rada.gov.ua/laws/show/973_002\#Text. [in Ukrainian].

Tomliak T. S. Genesis of the principle of ensuring the best interests of the child in international law

The article is devoted to the genesis of the principle of ensuring the best interests of the child as the main legal category used in the field of children's rights. The norms of international law in the field of protection of the best interests of the child are analyzed. In particular, the provisions of the Convention on the Rights of the Child and its Optional Protocols, the 1980 Convention on the Civil Aspects of International Child Abduction, the 1993 Convention on the Protection of Children and Cooperation in Respect of International Adoption; Conventions on Jurisdiction, Applicable Law, Recognition, Enforcement and Cooperation in Respect of Parental Responsibility and Child Protection Measures of 1996 and a number of others. The tendencies of formation of the principle of ensuring the best interests of the child are singled out.

It has been proven that the definition of the principle of the best interests of the child was first used in the 1989 Convention on the Rights of the Child, but for more than twenty years there has been no definition of the principle of the best interests of the child in international and national law. It is concluded that such a gap in the legislation leads to legal uncertainty in the consideration of cases involving children by state and judicial bodies.

It is determined that the concept of "best interests of the child" is broader than the concept of "rights and freedoms of the child". It is proposed to amend the Law of Ukraine "On Child Protection" and introduce the concept of "the principle of legal protection of the best interests of the child", namely to supplement Article 1 of the Law of Ukraine "On Child Protection" paragraph 22 as follows: "The principle of ensuring the best interests of the child - is reflected in international treaties and enshrined in national law fundamental principles and guidelines aimed at the harmonious development of the child, ensuring its needs and interests as a broader concept than the rights and freedoms of the child, taking into account exclusivity and features every child. "

Key words: child, rights, genesis, principle, best interests, family relations, parents. 
УДК 341.24:327.5 (477+73)

DOI https://doi.org/10.31392/NPU-nc.series18.2021.36.12

Харитонов Р. Ф.

\section{МІЖНАРОДНО-ПРАВОВИЙ АСПЕКТ ВІДНОСИН МІЖ УКРАЇНОЮ ТА США (1991-1994 РР.)}

Розбудова сучасної держави можлива лише у тісному взаємозв'язку з іншими державами. Нині США є прикладом успішного економічного розвитку та успіху у прочесі державотворення. Проблема історико-правового розвитку відносин між Україною та США є важливою з погляду сучасного геополітичного становища нашої держави та державної стратегії щодо інтеграції у євроатлантичний простір. У статті розглядається процес розвитку міждержавних відносин починаючи з моменту проголошення нашою державою незалежності у 1991 році до сьогоднішнього дня. Фактично починаючи з 2014 року наша держава перебуває в новій геополітичній реальності, яка потребує переосмислення власної суб 'єктності в сучасному світі та визначення нових підходів до співробітництва зі своїми стратегічними партнерами, зокрема зі Сполученими Штатами Америки. У політииі адміністрацій президентів США незалежна Україна сприймалася по-різному. Бачення ними молодої держави змінювалося, еволючіонувало залежно від подій і становища на міжнародній арені, внутрішнього життя Украӥни та, власне, від особливостей підходу американських адміністрацій.

3 обранням нового Президента США Джо Байдена Україна та США отримали унікальний шанс поглибити двосторонні міждержавні відносини з урахуванням довгострокових національних інтересів обох країн. Це особливо важсливо з огляду на те, що значення україно-американського «стратегічного партнерства» виходить за межі суто двосторонніх відносин - його подальше змічнення позитивно впливатиме на подолання викликів регіональної та європейської безпеки. США та інші країни Заходу відмовились від погляду про належність України до пострадянського простору, враховуючи те, щзо Україна довела свою відданість изіностям демократії та прав людини.

Ключові слова: міждержавні відносини, Україна, США.

Протягом останніх років наша держава відчуває на собі численні наслідки анексії Автономної Республіки Крим та окупації окремих районів Луганської та Донецької областей. Російська Федерація брутально порушила норми міжнародного права та весь корпус двосторонніх договорів.

Фактично починаючи з 2014 року наша держава перебуває в новій геополітичній реальності, яка потребує переосмислення власної суб'єктності в сучасному світі та визначення нових підходів до співробітництва зі своїми стратегічними партнерами, зокрема зі Сполученими Штатами Америки. Недаремно міністр закордонних справ Д. Кулеба нещодавно закликав США та інші країни Заходу відмовитись від погляду про належність України до пострадянського простору, враховуючи те, що Україна довела свою відданість цінностям демократії та прав людини. На думку міністра, США та Свропа мають визнати, що Україна є невід'ємною частиною Заходу [10].

3 обранням нового Президента США Джо Байдена Україна та США отримали унікальний шанс поглибити двосторонні міждержавні відносини з урахуванням довгострокових національних інтересів обох країн. Саме з цією метою Президент України Володимир Зеленський нещодавно здійснив довгоочікуваний візит до США, де провів конструктивні перемовини 3 Президентом Байденом. Це підтверджується текстом комюніке, де зазначено, що «успіх України має центральне значення для глобальної боротьби між демократією та автократією. Коли ми спільно стикаємося з цим викликом, ми стоїмо пліч-о-пліч та маємо оптимізм стосовно наших амбітних спільних цілей щодо просування демократії, забезпечення справедливості, покращення добробуту та зміцнення безпеки України... Україна досягла прогресу в розбудові доброчесних інституцій та має намір, за підтримки США, продовжувати протидію корупції, забезпечувати підзвітність, захищати права людини, реалізовувати прагнення своїх громадян та створювати сприятливі умови для залучення прямих іноземних інвестицій і стимулювання зростання» [1]. 
Проте, незважаючи на цілком дружню атмосферу, між нашими державами залишаються певні суперечності, плідне вирішення яких цілком залежить від розуміння перших років становлення наших відносин. Саме це зумовлює актуальність цієї розвідки для вітчизняної історико-правової та міжнародно-правової науки.

Питанням місця України серед зовнішньополітичних інтересів США займалося значне коло вчених. Серед вітчизняних та іноземних науковців можна назвати К. Агитона, Р. Асмуса, 3. Бжезінського, Н. Корнієнко, Д. Лакішика, М. Лимара, І. Погорську, Дж. Ріллі, Н. Середюк, О. Сивак, П. Соломона, А. Худолія.

Розглядаючи зазначену проблематику, доцільно зазначити, що зовнішня політика США грунтувалася насамперед на захисті власних національних інтересів, пріоритети щодо яких детермінувалися в залежності від конкретних історичних умов. Розпад Радянського Союзу та поява на його теренах низки нових незалежних держав вимагали від США концептуального переосмислення місця цього регіону в зовнішньополітичній стратегії країни. Американські вчені закликали розглядати Україну як точку деомкратичного опору у Східній Свропі, реформування якої важливе для гарантії безпеки в Свропі та для демократізації в Росії [20, p. 77].

Провідна роль США у закінченні холодної війни та оформленні нового світового порядку сприяла досягненню консенсусу між республіканцями і демократами щодо необхідності подальшої активної присутності Америки на міжнародній арені. Однак причини досягнення цієї згоди були вкрай різними. Демократи висловлювали бажання зберегти за США статус світового лідера. В основі цього наміру лежить «ідеалістичний» підхід до міжнародної політики, за яким США історично покликані поширювати у світі демократичні цінності та ринкові ідеали. Натомість українська вчена I. Погорська вважає, що республіканці виступали прихильниками реалістичної школи міжнародної політики, яка ставила ідеологію та інші внутрішньополітичні чинники на другорядне місце у формуванні стратегії міждержавних відносин. Силова могутність держави в міжнародній системі та ії геополітичне залучення в регіоні, на їхню думку, посідали першочергове місце [13, с. 30].

Як уважає українська дослідниця Н. Корнієнко, у зовнішній політиці США можна виділити три основні напрями, що мали забезпечувати іiі лідерство в постбіполярному світі [9, с. 44]:

- контроль над зброєю масового знищення;

- поширення демократичних цінностей у світі разом зі впровадженням ринкової економіки;

- протистояння міжнародному тероризму.

Перемога «ліберально-демократичної традиції» надала можливість для зміцнення лідерства США через впровадження американської моделі в інших державах світу. Результатом цього стала сформульована політика так званого «Вашингтонського консенсусу», яка містила в собі основні політичні (демократія) та економічні (вільний ринок) принципи, які США намагались закріпити в державах перехідного типу, серед яких були й держави пострадянського простору $[5$, c. 45$]$.

У політиці адміністрацій президентів США незалежна Україна сприймалася по-різному. Бачення ними молодої держави змінювалося, еволюціонувало залежно від подій і становища на міжнародній арені, внутрішнього життя України та, власне, від особливостей підходу американських адміністрацій.

Геополітичне розташування України зацікавило США в іiі незалежності та здатності нейтралізувати розширення російського впливу за її державні кордони.

Від часу проголошення незалежності України українсько-американські відносини розвивалися під впливом двох трендів: ідеологічного та прагматичного. Зокрема, ідеологічний тренд базувався на відомій тезі ключової геополітичної ролі України, яку сформулював американський дослідник 3. Бжезінський. Він зазначив, що провідна роль Сполучених Штатів на пострадянському просторі вимагає докладання зусиль з метою утримання України у своїй сфері впливу для ії зміцнення та просування інтересів на міжнародній арені [12, с. 144].

На початку 1990-х років американські державні діячі наголошували, що політико-системні характеристики України як перехідної держави належать до однієї з найбільш виразних осо- 
бливостей нового стратегічного ландшафту Європи. На той час Україну передусім розглядали як важливий стратегічний буфер між Європою і Росією. 3 погляду американської політичної стратегії суверенна та стабільна Україна обмежувала сфери впливу Росії на інші регіони. Поки Україна залишається незалежною, стверджували вищі керівники американської держави, вона може бути справді ефективним буфером між Росією та Європою [18, p. 30].

Американсько-українські відносини після «холодної війни» були непростими від початку проголошення незалежності. У липні 1991 року Дж. Буш-ст. здійснив візит до України, яка розцінювала такий крок як знак підтримки прагнення до незалежності. У своїй промові, яка завдяки журналісту «New York Times» В. Сефайєру ввійшла в історію як Chicken Kiev Speech («котлета по-київськи»), Дж. Буш-ст. наголосив на двох блоках понять: згадці про колишній СРСР та власне проблемі незалежності України. Ключовою, на думку українського професора А. Худолія, стала вимога відмовитися від курсу на незалежність, який обрав український народ [17, с. 116]. Президент Дж. Буш-ст. зазначив: «але свобода - це не те ж саме, що незалежність. Американці не будуть підтримувати тих, хто прагне незалежності для того, щоб замінити тиранію на місцевий деспотизм. Ми не будемо допомагати тим, хто сприяє самовбивчому націоналізмові» $[17$, с. 116]. Вочевидь, США боялись розповсюдження ядерної зброї та були зацікавлені у збереженні Радянського Союзу в послабленному стані.

За рік до проголошення незалежності Верховна Ради УРСР прийняла Декларацію про державний суверенітет України, в якій було зазначено, що Українська РСР виступає рівноправним учасником міжнародного спілкування, активно сприяє зміцненню загального миру і міжнародної безпеки, безпосередньо бере участь у загальноєвропейському процесі та європейських структурах. Крім того, у Декларації визнавалась перевага загальнолюдських цінностей над класовими, пріоритет загальновизнаних норм міжнародного права перед нормами внутрішньодержавного права. Фактично, Декларація затверджувала миролюбний характер майбутньої незалежної держави [4].

Офіційне визнання України як незалежної суверенної держави США здійснили 25 грудня 1991 року. За тиждень, а отже, 3 січня 1992 року, були встановлені дипломатичні відносини між двома країнами. США гарантували суверенітет, незалежність, територіальну цілісність і непорушність кордонів України, а також високо оцінили зусилля українського уряду зі зміцнення національної економіки і забезпечення політичної стабільності в умовах подальшого посилення демократичних стандартів [14, с. 35].

Розвиваючи стратегічне партнерство зі США, Україна усвідомлювала ключову роль, яку ця наддержава відіграє в системі політичних, економічних, науково-технологічних, воєнно-політичних координат нинішнього світу.

Історико-правова характеристика відносин між Україною та США протягом 1991-1994 років містить певні етапи, кожен з яких віддзеркалює особливості внутрішньої та зовнішньополітичної ситуації в обох країнах та міжнародної ситуації в цілому.

На початку в українсько-американських відносинах домінував «російський підхід». Враховуючи власні інтереси, США та Росія посилили тиск на Україну з метою змусити ії ліквідувати арсенал ядерної зброї. Головною метою зовнішньої політики України на американському векторі в цей період стало здобуття від США реального визнання України як рівноправного партнера.

5-11 травня 1992 року відбувся перший офіційний робочий візит Президента України Л. Кравчука до США, під час якого було підписано політичну декларацію та меморандум про взаєморозуміння між урядами України та США. Хоч у політичній декларації вперше було зафіксовано формулу «демократичного партнерства» двох країн, практика тодішніх українсько-американських відносин залишалася на тому самому рівні [14, с. 35].

Наступний етап розвитку українсько-американських відносин, що тривав до кінця 1993 року, набув значного потепління. Новий Президент США Білл Клінтон, обраний 1992 року, почав змінювати підхід американської адміністрації до України. Частково ця зміна була викликана посиленням антидемократичних тенденцій у Росії. До кінця 1993 року нова політика США стосовно України і налагодження двосторонніх та тристоронніх переговорів стали фундаментом для порозуміння між двома державами. 
Б. Клінтон поставився до проблем України зі значно більшим порозумінням, ніж його попередники. Усвідомлюючи те, що українсько-російські суперечності навряд чи вдасться вирішити без втручання третьої сторони, було вирішено розширити участь України в ініційованих США переговорах із вирішення політичних і економічних питань безпеки, які б привели, у свою чергу, до вирішення ядерного питання.

Кінцевим результатом цієї нової політики стало підписання в Москві 14 січня 1994 року тристоронньої угоди, що здійснили Президенти Б. Клінтон, Л. Кравчук та Б. Сльцин, згідно 3 якою Україна зобов'язувалася знищити всю ядерну зброю, розташовану на іiї території, протягом семи років. Виконання Договору про нерозповсюдження ядерної зброї відбулося в жовтні 1994 року [16, с. 87].

У Спільній заяві про розвиток дружби і партнерства між Україною та США від 4 березня 1994 року було викладено функціонально обумовлений перелік основних сфер і напрямів двостороннього співробітництва й закріплено його мету: «докласти зусиль для розширення змісту двосторонніх відносин на основі партнерства, взаємної довіри та поваги» [2]. Згодом у Хартії українсько-американського партнерства, дружби і співробітництва від 22 листопада 1994 року було використано формулювання «міцне партнерство» та вміщено перелік з 10 пунктів, які конкретизували засади, цілі та основні напрями двосторонньої взаємодії [11, с. 52]. Хартія вперше містила умовне положення, відповідно до якого в залежності від успішності просування «привабливого правового та фінансового клімату для міжнародних інвестицій» США брали на себе готовність сприяти заохоченню американського приватного бізнесу до входження в ринок України [3].

Крім того, США підтвердили готовність підтримати Україну в її зусиллях, спрямованих на вирішення суперечностей з її сусідами в дусі миру та співпраці та на утримання від загрози силою або ії застосування проти територіальної цілісності або політичної незалежності будьякої держави [3]. Таким чином, Україна легітимізувала можливість США брати участь у вирішенні російсько-українських проблем, що означало можливість упевненіше відстоювати свої позиції у відносинах з економічно могутнішою Росією, подвоєння американських коштів у вигляді економічної допомоги для вирішення проблем та надання гарантій безпеки з боку США, Великої Британії, а також Росії.

Наступний етап у міждержавних відносинах розпочався 1994 року, коли адміністрація Б. Клінтона підтримала ідею залучення України до світової спільноти та проголосила у США 1994 рік «роком України». Саме з цього часу потепління у ставленні до України з боку США, що намітилося 1993 року, стало очевидним. Адміністрація Б. Клінтона почала вести активну політику, спрямовану на залучення України до світового співтовариства та його інституцій [6, с. 117].

Ще одним напрямом зацікавленості США Україною стало поширення демократичних цінностей в Україні паралельно з розвитком ринкової економіки.

Президент Б. Клінтон 1994 року навіть запровадив так звану «доктрину розширення», в якій йшлося про збільшення кількості країн з демократичним устроєм та вільними ринками. Це обгрунтовувалось тим, що держави з демократичним устроєм є більш мирними та, як наслідок, дружними до США. «Безпечні нації більш схильні підтримувати вільну торгівлю і підтримувати демократичні структури... Демократичні держави 3 меншою ймовірністю загрожують нашим інтересам, і більш імовірно співпрацюватимуть з США для упередження безпекових загроз і сприяння сталому розвитку» [9, с. 47].

Відвідавши Київ, Президент Клінтон зазначив важливість місця та ролі, яку відіграє Україна для Свропи: «Я впевнений, що Україна може відіграти важливу роль у майбутньому Європи, безпека якої грунтується на демократичних засадах, ринковій економіці та взаємоповазі до існуючих кордонів». Проте насправді Б. Клінтон був зацікавлений у зміцненні України насамперед як противаги та стримуючого чинника для Росії [17, с. 116].

Новий Президент України Л. Кучма одразу після приходу до влади восени 1994 року проголосив курс на проведення ліберальних економічних реформ. Саме за часів президентства Б. Клінтона популярними стали концепції 3. Бжезінського та Шермана Гарнетта про геострате- 
гічну важливість України на пострадянських теренах для забезпечення національного інтересу США та безпеки в регіоні, оскільки у США сподівалися, що Україна порівняно швидко подолає перехідний період і незабаром стане головною фігурою американського впливу на Росію [7, c. 13].

Починаючи ще з 1991 року Україна орієнтувала себе на «стратегічний курс приєднання до Європи», наполегливо визначаючи себе саме європейськими, а не євразійськими термінами. Проте, оскільки на півночі Україна мала такого сусіда, як Росія, який ніколи повністю не відмовлявся від своїх геополітичних претензій та часто використовував економічну залежність України у політичних цілях, Україна не могла дозволити собі провадити прозахідну політику.

У зв’язку з цим 1994 року був прийнятий «багатовекторний» курс української зовнішньої політики, який грунтувався на такій концепції: Україна не буде в безпеці доти, доки Росія не вирішить для себе, що незалежність України та ії прозахідна орієнтація відповідають російським національним інтересам. Таким чином, необхідною умовою української багатовекторної політики та «стратегічного партнерства» з Росією ставали дружні відносини між Росією та Заходом.

Значною мірою українська «багатовекторність» концентрувалась у цей час на українсько-американських відносинах. Ще під час державного візиту до США Президента України Л. Кучми в листопаді 1994 року був підписаний один з основоположних документів двосторонніх відносин - Хартія українсько-американського партнерства, дружби та співробітництва [8, с. 8].

Рішення про започаткування «стратегічного партнерства» було важливим досягненням обох країн, хоч надалі реалії українсько-американських відносин не завжди відповідали його умовам.

Із плином часу бачення геостратегічної важливості місця України на Заході, й особливо у США, змінилося. В американської сторони на зміну самодостатнього сприйняття потенційного впливу, який Україна могла б справляти на убезпечення регіону, прийшло усвідомлення того, що без внутрішнього зміцнення держави ії̈ потенціал не можна використати.

США не влаштовував той факт, що позитивні зрушення відбувалися надто повільно, незважаючи на те що в реформування свого «стратегічного партнера» було вкладено значних коштів. США прагнули якнайскоріше вийти зі стадії надання матеріальної допомоги Україні та перейти до стадії, коли б економічні відносини між двома державами відбувалися за рахунок природного інтересу американського приватного капіталу [15, с. 5].

Дедалі більшого контрасту набули бажання України бути європейською державою та дійсність. На Заході зростало невдоволення невизначеністю і непередбачуваністю української «багатовекторності», яку почали розглядати як політику «маятника» від Заходу до Росії, та частими намаганнями України покращити свої відносини з одним із них за рахунок іншого $[16$, c. 90$]$.

Таким чином, українсько-американські відносини від самого початку були динамічними та суперечливими одночасно.

Слід констатувати, що принциповими факторами, що негативно впливали на американськоукраїнські відносини, були невизначеність меж стабілізації української внутрішньополітичної системи та повільний процес демократичного реформування.

Безперечно, США мали визначальний вплив на формування та розвиток України як незалежної держави, але слабка позиція української політики, ії системна невизначеність постійно підривали основи двостороннього «стратегічного партнерства».

Розвиток відносин між Україною та США саме протягом 1991-1994 років найбільш розкрито характеризує історико-правову основу взаємодій цих двох країн.

Стратегічна і тактична дії США щодо України базувалися на прагматиці реалістичного підходу, що визначала пряму залежність ефективності двосторонньої взаємодії від чіткості реалізації останньою стратегічних орієнтирів на інтеграцію до євроатлантичної спільноти.

Саме в цей період були зроблені найбільш важливі кроки на шляху до досягнення вигідних домовленостей та проектів, установлення надійних «ліній комунікації» між керівництвами двох країн. 
Це особливо важливо з огляду на те, що значення україно-американського «стратегічного партнерства» виходить за межі суто двосторонніх відносин - його подальше зміцнення позитивно впливатиме на подолання викликів регіональної та європейської безпеки.

Історія відносин США та України кінця 1990-х - початку 2000-х років зазнавала змін. Якщо на початку 1990-х років США називали Україну важливим геополітичним партнером на пострадянському просторі, то на початку 2000-х, особливо в контексті загального невдоволення якістю і темпами демократизації, а також наявністю серйозних проблем у сфері забезпечення свободи засобів масової інформації, приходило реальне бачення дійсності. Відносини між країнами зазнавали серйозної перевірки на міцність - можна стверджувати про своєрідну форму напівізоляції України від західного співтовариства націй [21, р. 72].

\section{Використана література:}

1. Спільна заява щодо стратегічного партнерства України та Сполучених Штатів Америки. 2021. URL: https:/www.president.gov.ua/news/spilna-zayava-shodo-strategichnogo-partnerstva-ukrayinita-s-70485 (дата звернення: 14.08.2021).

2. Спільна заява про розвиток дружби і партнерства між Україною та Сполученими Штатами Америки. 1994. URL: https://zakon.rada.gov.ua/laws (дата звернення: 11.08.2021).

3. Хартія українсько-американського партнерства, дружби і співробітництва. 1994. URL: https:// zakon.rada.gov.ua (дата звернення: 14.08.2021).

4. Декларація про державний суверенітет України. 1990. URL: https://zakon.rada.gov.ua (дата звернення: 10.08.2021).

5. Агитон К. Альтернативный глобализм. Новые мировые движения протеста / пер с франц. под общ. ред. Ю. Марковой; науч. ред. К. Клеман. Москва: Гилея, 2004. 204 с.

6. Бжезінський 3. Велика шахівниця. Київ: Фабула, 2018. 288 с.

7. Бжезінський 3. Вирішальна роль України на пострадянському просторі. Політика $i$ час. 1997. № 9. С. 24-28.

8. Камінський С. Українсько-американські відносини на початку 21-го століття. Дослідження світової політики: зб. наук. пр. 2003. Вип. 23. С. 8-13.

9. Корнієнко Н. Місце України серед зовнішньополітичних пріоритетів США у пост-біполярний період. Сполучені Штати Америки у сучасному світі: політика, економіка, право, суспільство. Ч 2: матеріали II Міжнар. наук.-практ. конф. (м. Львів, 15 трав. 2015 р.) / упоряд.: Р. Калитчак, 3. Зазуляк. Львів: Центр амер. студій ФМВ ЛНУ ім. І. Франка, 2015. С. 43-51.

10. Кулеба Д. Україна є частиною Заходу: HATO та ЄC мають сприймати iї саме так. URL: https:// www.foreignaffairs.com/articles/ukraine/2021-08-02/ukraine-part-west (дата звернення: 14.08.2021).

11. Лакішик Д. Особливості американсько-українських відносин у 1991-2004 pp. Американська історія та політика. 2018. Вип. 5. С. 50-58.

12. Лимар М. Основні тенденції україно-американських відносин на початку XXI століття. Міжнародні відносини і туризм: сучасність та ретроспектива. 2013. Вип. 3. С. 143-147.

13. Погорська I. США: місія здійснима? Праксеологія творення глобального світу. Київ: Грамота, 2009. $520 \mathrm{c}$.

14. Середюк Н. Стратегічне партнерство Україна-США. Вісник КНУ. Серія: Міжнародні відносини. 2017. Вип. 46. URL: http://journals.iir.kiev.ua/index.php/knu/article/view/3261 (дата звернення: 14.08.2021).

15. Сполучені Штати Америки у сучасному світі: політика, економіка, право, суспільство. Ч 1: матеріали II Міжнар. наук.-практ. конф. (м. Львів, 15 трав. 2015 р.) / упоряд.: Р. Калитчак, 3. Зазуляк. Львів: Центр амер. студій ФМВ ЛНУ ім. І. Франка, 2015. 476 с.

16. Сивак О., Черник П. Новітні україно-американські відносини. Українська національна ідея: реалії та перспективи розвитку. 2010. Вип. 22. С. 87-93.

17. Худолій А. Американсько-українські відносини в світлі викликів XXI століття. Американська історія та політика. 2016. № 1. С. 115-122.

18. Asmus R., Kugler R., Larrabee F. Building a New NATO. Foreign Affairs. 1993. Vol. 72, №. 4. P. $28-40$.

19. Bush G. H. «Chicken Kiev Speech»/ Remarks to the Supreme Soviet of the Republic of the Ukraine in Kiev, Soviet Union, August 1, 1991. URL: http://www.presidency.ucsb.edu (дата звернення: 14.08.2021).

20. Riley J. Ukraine: A promising US partner for the 2st centuty: Thesis. Troy State University, 1995. 87 p. 
21. Solomon P., Foglesong T. The Two Faces of Crime in Post-Soviet Ukraine. East European Constitutional Review. 2000. V. 9(3). P. 72-76.

\section{References:}

1. Spilna zaiava shchodo stratehichnoho partnerstva Ukrainy ta Spoluchenykh Shtativ Ameryky [Joint Statement on the Strategic Partnership between Ukraine and the United States of America], (2021), URL: https://www.president.gov.ua/news/spilna-zayava-shodo-strategichnogo-partnerstva-ukrayinita-s-70485 (accessed 14.08.2021) [in Ukrainian].

2. Joint statement on the development of friendship and partnership between Ukraine and the United States of America [Joint statement on the development of friendship and partnership between Ukraine and the United States of America] (1994) URL: https://zakon.rada.gov.ua/laws (accessed 11.08.2021) [in Ukrainian].

3. Khartiia ukrainsko-amerykanskoho partnerstva, druzhby i spivrobitnytstva [Charter on UkrainianAmerican Partnership, Friendship and Cooperation] (1994) URL: https://zakon.rada.gov.ua (accessed 14.08.2021) [in Ukrainian].

4. Deklaratsiia pro derzhavnyi suverenitet Ukrainy [Declaration of State Sovereignty of Ukraine] (1990) URL: https://zakon.rada.gov.ua (accessed 10.08.2021) [in Ukrainian].

5. Agiton K. (2004) Alternativnyiy globalizm. Novyie mirovyie dvizheniya protesta [Alternative globalism. New world protest movements], Moscow, Gileya, 204 p [in Russian].

6. Bzhezinskyi Z. (2018) Velyka shakhivnytsia [Big chessboard] Kyiv, Fabula, 288 p.

7. Bzhezinskyi Z. Vyrishalna rol Ukrainy na postradianskomu prostori [Ukraine's crucial role in the postSoviet space], Polityka i chas [Politics and time 1997. no. 9. P. 24-28 [in Ukrainian].

8. Kaminskyi Ye. Ukrainsko-amerykanski vidnosyny na pochatku 21-ho stolittia [Ukrainian-American relations at the beginning of the 21st century], Doslidzhennia svitovoi polityky [Research of world politics] 2003, vol. 23. P. 8-13 [in Ukrainian].

9. Korniienko N. Mistse Ukraïny sered zovnishnopolitychnykh priorytetiv SShA u post-bipoliarnyy period [Ukraine's place among US foreign policy priorities in the post-bipolar period] Spolucheni Shtaty Ameryky u suchasnomu sviti: polityka, ekonomika, pravo, suspilstvo [The United States of America in the modern world: politics, economics, law, society] Lviv, 2015. P. 43-51 [in Ukrainian].

10. Kuleba D. Ukraina ye chastynoiu Zakhodu: NATO ta YeS maiut spryimaty yii same tak [Ukraine is part of the West: NATO and the EU should see it that way] URL: https://www.foreignaffairs.com/ articles/ukraine/2021-08-02/ukraine-part-west (accessed 14.08.2021) [in Ukrainian].

11. Lakishik D. Features of American-Ukrainian relations in 1991-2004. [Features of American-Ukrainian relations in 1991-2004] Amerykanska istoriia ta polityka [American history and politics], 2018, vol. 5. P. 50-58 [in Ukrainian].

12. Lymar M. Osnovni tendentsii ukraino-amerykanskykh vidnosyn na pochatku XXI stolittia [The main trends of Ukrainian-American relations at the beginning of the XXI century] Mizhnarodni vidnosyny $i$ turyzm: suchasnist ta retrospektyva [International relations and tourism: modernity and retrospective], 2013, vol. 3. P. 143-147 [in Ukrainian].

13. Pohorska I. SShA: misiia zdiisnyma? Prakseolohiia tvorennia hlobalnoho svitu [USA: is the mission feasible? Praxeology of the creation of the global world], Kyiv, Hramota, 2009. 520 p [in Ukrainian].

14. Serediuk N. Stratehichne partnerstvo Ukraina-SShA [Strategic partnership Ukraine-USA] Visnyk KNU. Seriia: Mizhnarodni vidnosyny [Bulletin of the KNU. Series: International Relations], 2017, vol. 46. URL: http://journals.iir.kiev.ua/index.php/knu/article/view/3261 (accessed 14.08.2021) [in Ukrainian].

15. Spolucheni Shtaty Ameryky u suchasnomu sviti: polityka, ekono-mika, pravo, suspilstvo [The United States of America in the modern world: politics, economics, law, society], Lviv, 2015. $476 \mathrm{p}$ [in Ukrainian].

16. Syvak O., Chernyk P. Novitni ukraino-amerykanski vidnosyny, [The latest Ukrainian-American relations], Ukrainska natsionalna ideia: realii ta perspektyvy rozvytku, [Ukrainian national idea: realities and prospects of development], 2010.,vol. 22. P. 87-93 [in Ukrainian].

17. Khudolii A. Amerykansko-ukrainski vidnosyny v svitli vyklykiv XXI stolittia, [American-Ukrainian relations in the light of the challenges of the XXI century], Amerykanska istoriia ta polityka [American history and politics], 2016. no. 1. P. 115-122 [in Ukrainian].

18. Asmus R., Kugler R., Larrabee F. Building a New NATO. Foreign Affairs. 1993. Vol. 72, №. 4. P. 28-40. 
19. Bush G. H. «Chicken Kiev Speech» / Remarks to the Supreme Soviet of the Republic of the Ukraine in Kiev, Soviet Union, August 1, 1991. URL: http://www.presidency.ucsb.edu (дата звернення: 14.08.2021).

20. Riley J. Ukraine: A promising US partner for the 2st centuty: Thesis. Troy State University, 1995. $87 \mathrm{p}$.

21. Solomon P., Foglesong T. The Two Faces of Crime in Post-Soviet Ukraine. East European Constitutional Review. 2000. V. 9(3). P. 72-76.

Kharytonov R. F. International legal aspect of relations between Ukraine and the United States (1991-1994)

Building a modern state is possible only in close cooperation with other states. Today, the United States is an example of successful economic development and success in the state-building process. The problem of historical and legal development of relations between Ukraine and the United States is important from the point of view of the current geopolitical situation of our state and the state strategy for integration into the Euro-Atlantic space. The article considers the process of development of interstate relations from the moment of our declaration of independence in 1991 to the present day. In fact, since 2014, our country has been in a new geopolitical reality, which requires rethinking its own subjectivity in the modern world and defining new approaches to cooperation with its strategic partners, including the United States. Independent Ukraine was perceived differently in the policies of US presidential administrations. Their vision of a young state changed, evolved depending on events and the situation on the international arena, the internal life of Ukraine and, in fact, the peculiarities of the approach of American administrations.

With the election of new US President Joe Biden, Ukraine and the United States have a unique chance to deepen bilateral interstate relations, taking into account the long-term national interests of both countries. This is especially important given that the importance of the Ukrainian-American "strategic partnership" goes beyond purely bilateral relations - its further strengthening will have a positive impact on overcoming the challenges of regional and European security. The United States and other Western countries must abandon the view that Ukraine belongs to the post-Soviet space, given that Ukraine has proven its commitment to the values of democracy and human rights.

Key words: interstate relations; Ukraine; USA. 
Чорний Г. О., Савченко Р. I.

\section{ДО ПОСТАНОВКИ ПИТАННЯ ЩОДО ПРОФЕСІЙНОЇ ДЕФОРМАЦІЇ ПРАЦІВНИКІВ НАЦІОНАЛЬНОЇ ПОЛІЦІЇ УКРАЇНИ ЯК ОДНІЄЇ $З$ ПРИЧИН ПОРУШЕННЯ ПРАВ ЛЮДИНИ ТА ЗАСТОСУВАННЯ НАСИЛЬСТВА}

Стаття присвячена дослідженню такого важливого психологічного явища у діяльності працівників правоохоронних органів, як професійна деформація.

Доведено, щуо необхідною умовою ефективної діяльності правоохоронних органів є дотримання принциипів верховенства права та забезпечення захисту прав людини. Констатовано, щзо це здійснить вплив не лише на стан дотримання прав людини, а й на рівень довіри до поліиії, цей фактор є основним показником для оцінки ефективності діяльності поліиії.

Звернено увагу, щз професійна деформаџія властива кожній професії і є неминучим та небажаним явищем. Встановлено, щзо професія працівника правоохоронного органу є однією з найбільш вразливих до формування та розвитку професійної деформачії. Зокрема, через особливі риси такої діяльності - умови праці, коло обов'язків, фізичне та психічне навантаження, наявність конфліктних ситуацій тощзо.

Висунуто гіпотезу, що однією з причин, яка може призвести до застосування працівником правоохоронного органу насильства, є професійна деформація особистості такого працівника. Явище професійної деформащії особистості працівника правоохоронного органу розглянуто $і$ як одну із причин порушення ним прав людини та вчинення злочину.

Синтезовано підходи до визначення феномену професійної деформації. Встановлено, що професійна деформація зумовлена комплексом причин, серед яких є сочіальні, політичні, моральні, адміністративні та інші. Визначено чинники, які можуть призвести до професійної деформації працівника правоохоронного органу. Висвітлено розповсюдження професійної деформаиї̈ не лише на службову сферу працівника правоохоронного органу, але й на його особисте життя та оточення.

Здійснено підсумок, щзо на попередження та усунення професійної деформації як загального феномена мають бути спрямовані зусилля не лише самого правоохоронного органу, але й суспільства та держави.

Ключові слова: професійна деформація, працівник правоохоронного органу, права людини, застосування насильства.

Відповідно до положень статті 3 Конституції України найвищою соціальною цінністю в державі визнається людина, її життя, здоров'я, честь і гідність, недоторканність і безпека. Права і свободи людини, а також їх гарантії визначають зміст і спрямованість держави, а утвердження та забезпечення прав і свобод людини є головним їі обов’язком [1].

Національна поліція України є центральним органом виконавчої влади, який служить суспільству шляхом забезпечення охорони прав і свобод людини, протидії злочинності, підтримання публічної безпеки і порядку [2]. Поліція є найбільшим за чисельністю кадрового складу правоохоронним органом в Україні.

Під час виконання своїх службових обов'язків поліцейський постійно контактує з людьми. Теж саме стосується і громадян, які у випадку порушення їхніх прав чи свобод мають право звернутися за захистом до правоохоронних органів. Цей спосіб захисту прав $є$ доволі поширеним.

Однак, поряд із забезпеченням та захистом прав і свобод людини, поліція водночас може бути і їх потенційним порушником. Важливим аспектом забезпечення прав людини в діяльності Національної поліції України є недопущення проявів насильства та викорінення фактів жорстокого поводження з людьми [3, с. 176]. Тому для цього видається необхідним встановити причини і умови, що породжують такі дії. Однією з причин, яка може призвести до застосування насильства представником правоохоронного органу і порушення прав людини, є професійна деформація особистості такого працівника. 
Особливістю поліцейської діяльності є те, що суб’єкт її реалізації є представником держави, тому під час несення служби він діє від імені держави, що зумовлює формування вертикальних відносин з іншими людьми. Такі відносини умовно можна зобразити, як відносини «держава-людина». Саме у згаданих вертикальних відносинах $є$ високий ризик порушення прав людини. Діяльність поліцейського потребує підвищеної моральної відповідальності за поведінку, здоров'я і життя окремих людей, груп населення та суспільства в цілому [4, с. 312]. Це викликає потребу більш детального розгляду механізмів впливу професії на людину задля того, щоб запровадити та працювати 3 діагностикою та корекцією професійних деформацій працівників.

Такі ознаки, як зловживання владою, правовий нігілізм, самовиправдання порушень службових норм інтересами і цілями боротьби зі злочинністю, зниження самоконтролю і вимогливості до себе, у структурі особистості працівника поліції можуть сприяти розвитку професійної деформації [5, с. 287]. У статті висувається гіпотеза щодо впливу професійної деформації на ситуацію із дотриманням прав людини, зокрема на випадки застосування насильства поліцією.

Метою статті є розгляд такого складного психологічного явища в діяльності поліції, як професійна деформація особистості працівника, в контексті однієї з причин порушення прав людини та застосування насильства. Метою роботи є також узагальнення підходів щодо визначення та класифікації професійної деформації працівника поліції; дослідження чинників, які призводять до професійної деформації (причин іiї появи), ії наслідків та шляхів попередження і боротьби.

Актуальність статті полягає у тому, що одним із основних принципів діяльності поліції є принцип верховенства права, відповідно до якого людина, іiї права та свободи визнаються найвищими цінностями та визначають зміст і спрямованість діяльності держави [2]. Враховуючи це, аспект дотримання прав людини поліцією набуває особливого значення. Актуальність роботи також зумовлена вимогами держави та суспільства щодо підвищення рівня ефективності діяльності правоохоронних органів, особливо у контексті дотримання прав людини; зростаючим значенням проблеми професійної деформації у працівників поліції; необхідністю комплексного наукового аналізу факторів та чинників, які зумовлюють виникнення та розвиток професійної деформації; недостатньою кількістю теоретичних і практичних досліджень особливостей прояву деформаційних ознак та розвитку професійної деформації; необхідністю формування нових підходів до профілактики та корекції різних проявів професійної деформації поліцейського. Системне дослідження згаданих питань викликає значний інтерес і в теоретичному, і в прикладному плані [6].

Питання, пов'язані із впливом професії на особу, вивчалися ще за часів давніх філософів, особливої уваги ця проблема набула наприкінці XIX - початку XX століття, зокрема завдячуючи Е.Ф. Зеєру та А.К. Марковій, коли у доктрині з'явився свій понятійний апарат щодо визначення феномену професійної деформації [7] [8].

Явище професійної деформації $є$ доволі науково розробленим та було предметом досліджень багатьох науковців, серед них - Ю.В. Александров, Е.А. Айроян, А.В. Буданов, С. Браун, С.Є. Борисова, Н.В. Вітрук, А.К. Глазичев, А.В. Дулов, О.М. Ігнатов, В. Полуектов, З.Р. Кісіль, Р.А. Кузнецов, Л. Мардахаєв, О.А. Мартиненко, К. Маслач, В.С. Медвєдєв, В. Самойлова, Д. Трунов, О.С. Новаков, М. Фірсов, О. Хухлаєва, С.А. Шалгунова та інші.

Питання злочинності в органах поліції та шляхів протидії їй розглядалося П.П. Андрушком, М.І. Ануфрієвим, О.Ф. Бантишевим, А.В. Галаховою, О.Ф. Гідою, Є.В. Додіним, О.О. Дудоровим, А.Ф. Зелінським, В.Ф. Кириченком, М.Й. Коржанським, Ю.І. Ляпуновим, П.С. Матишевським, М.І. Мельником, С.І. Ніколаюком, Г.В. Прокоповичем, М.М. Семендяєм, А.Н. Трайніним, О.Ю. Хабло, М.І. Хавронюком, Н.М. Ярмишем та іншими.

Незважаючи на те, що питання професійної деформації залишається у центрі наукових дискусій, наукові пошуки стосовно питань професійної деформації серед працівників правоохоронних органів є застарілими та потребують актуалізації. Водночас тематика професійної деформації поліцейського як однієї з причин порушення прав та свобод людини майже не розглядалася, а тому потребує уваги. 
Не підлягає доведенню те, що професійну правоохоронну діяльність неможливо уявити без аспекту дотримання прав людини. Це є принциповою умовою змісту діяльності поліції [9, c. 118].

Однак, за даними Харківського інституту соціальних досліджень, оцінна кількість жертв насильства в поліції у 2020 році становила 698926 осіб. За результатами попередніх аналогічних досліджень, така кількість жертв становила: 791700 осіб впродовж 2010 року, 409080 осіб впродовж 2015 року, 546686 осіб у 2018 році. Як бачимо, після незначного зниження кількості жертв незаконного насильства в поліції масштаби цього явища повернулись до показників 2017 року [10, с. 22].

На відносне зменшення порушень прав людини поліцією вплинули такі фактори, як запровадження нових положень КПК України, якими було надано нові гарантії дотримання прав людини; створення системи надання безоплатної правової допомоги, яка починає діяти із моменту затримання людини та певним чином стримує працівників правоохоронних органів від порушень; внутрішні зміни в поліції (реформи, запровадження нових інститутів - наприклад, Управління із забезпечення прав людини, системи Custody records); розвиток та зміцнення громадянського суспільства, його увага до дій поліції. Так, відносно нова система Custody records, яка запроваджується нині, $є$ результатом злагоджених дій представників громадянського суспільства та дозволяє попередити більшість порушень прав людини на етапі затримання особи та утримання їі у місцях тимчасового тримання.

Безумовно, згадані фактори не можуть повністю вплинути на стан дотримання прав людини правоохоронними органами. Протиправна діяльність поліції може порушувати майже всі основні права людини, починаючи від права на приватність, особисту недоторканність та закінчуючи правом на життя. Левова частка порушень прав людини поліцією, які документуються правозахисниками, стосуються безпідставних затримань, незаконного застосування сили, катувань та жорстокого поводження [11]. Тобто такі дії поліції зачіпають фундаментальні (невід’ємні) права, що безпосередньо пов’язані із людською честю та гідністю.

Систематичні порушення прав людини поліцією впливають не лише на рівень довіри населення, а й на рівень загальної злочинності. Так, через постійне порушення прав людини поліцією значне місце посідає злочинність з боку правоохоронних органів.

Явище професійної деформації характерне практично для всіх професій; рівень професійної деформації залежить від тривалості службової діяльності, їі особливостей та індивідуальних характеристик людини [12, с. 206] [13]. Багаторічне виконання професійної діяльності не може постійно супроводжуватися її вдосконаленням і безперервним професійним розвитком особистості [9]. Професійні деформації $є$ неминучими у кожній спеціальності і порушують цілісність особистості, знижують її адаптивність, стійкість, негативно позначаються на продуктивній діяльності. Професійні деформації - це зміни сформованої структури діяльності та особи, що негативно позначаються на продуктивності праці та взаємодії з іншими учасниками цього процесу. Багаторічне виконання однієї і тієї ж діяльності усталеними способами веде до розвитку професійно небажаних якостей та професійної дезадаптації фахівців [4, с. 313].

Відповідно до класифікації професій Є.О. Клімова, професійна діяльність працівників поліції належить до категорії «людина - людина» [14, с. 214]. Відповідний вид діяльності пронизаний людськими відносинами, які є стрижнем професії; для неї характерний тісний контакт з різними категоріями людей, де переплітаються людські взаємозв'язки і відносини: оперуповноважений та розшукуваний правопорушник; слідчий та підозрюваний тощо [15, c. 4].

Представники цього напряму діяльності, як зазначає Є.О. Клімов, мають справу із соціальними системами, співтовариствами і людьми різного віку [14]. Виконання посадових обов'язків пов'язане з підвищеною відповідальністю працівників за свої дії. Несення служби часто відбувається в ситуаціях із непередбачуваними наслідками, характеризується недостатньою визначеністю рольових функцій, психічними і фізичними перевантаженнями, необхідністю спілкування з різноманітним контингентом громадян, що вимагає від правоохоронця рішучих дій і здатності ризикувати. Ці специфічні особливості професійної діяльності значно впливають 
на особистісні характеристики ії представників і можуть спричиняти професійну деформацію працівників поліції [5, с. 287].

Як слушно зазначає В.Р. Кісіль, професійна деформація працівників правоохоронних органів $\epsilon$ реально існуючим явищем, яке наносить величезну шкоду правоохоронній діяльності [16]. Слід додати, що такий негативний вплив розповсюджується не лише на правоохоронну систему, а й на суспільство та державу загалом.

Є різні підходи до розуміння сутності та природи професійної деформації. Так, на думку автора фундаментального наукового дослідження В.С. Медведєва, яке $\epsilon$ досі актуальним, професійна деформація є комплексом своєрідних, взаємопов'язаних змін окремих якостей і особистості загалом, що виникають внаслідок виконання правоохоронних функцій [13].

С.П. Безносов сутність професійної деформації розуміє у тому, що під впливом виконання професійної ролі у людини змінюються ті чи інші властивості особистості, виникає професійний тип особистості, який проявляється і поза професійною сферою. Це - докорінна зміна людських властивостей, яку під впливом професії можна спостерігати у різних спеціальностях. Але особливо гостро вона проявляється у представників тих спеціальностей, які мають справу з людьми: працівники сфери обслуговування, медичний персонал, продавці, стюардеси, керівники колективів, учителі, співробітники правоохоронних органів, військові [6].

О. Бандурка та В. Медвєдєв професійну деформацію визначають як результат появи та розвитку жорстких професійних стереотипів, перенесення професійної ролі у сферу позаслужбових стосунків або впливу специфіки службової діяльності у професійну сферу [13, с. 16]. Деякі дослідники вважають, що професійна деформація є результатом невідповідності людини суспільній професійній нормі, що деформації розвиваються під впливом умов праці й віку, спотворюють конфігурацію особистісного профілю персоналу та негативно позначаються на продуктивності праці [13, с. 23].

$€$ й змішаний підхід до розуміння професійної деформації. Так, С.С. Борисова вважає, що професійна деформація є результатом взаємного впливу специфіки службової діяльності та професійної ролі, з одного боку, і особистісних характеристик - з іншого. Однак у цьому взаємному впливі основну роль відіграють чинники, пов'язані з особливостями виконуваної професійної діяльності та професійної ролі, оскільки саме вони сприяють розвитку особистих передумов і проявів професійній деформації [17]. Аналогічну позицію поділяють I.М. Хоржевська та В.В. Царапора, констатуючи, що головним чинником та ключовою детермінантою розвитку деструкцій є сама професійна діяльність [4, с. 315].

Професійна деформація несе за собою певні негативні наслідки, які стосуються не тільки самої особистості поліцейського, а й його соціального оточення та професійної діяльності.

Так, деформація у соціальній сфері призводить до формування негативного іміджу працівника правоохоронного органу, негативної громадської думки про діяльність поліції; упереджено-негативного ставлення до громадян, а також соціальної відчуженості та закритості. Деформація у згаданій сфері, як бачимо, безпосередньо впливає на діяльність поліції [15, с. 14]. Такий показник, як рівень довіри населення до поліції, є головним критерієм оцінки ефективності діяльності органів і підрозділів поліції відповідно до положень Закону України «Про Національну Поліцію України» [2]. За даними більшості досліджень рівень довіри громадян до поліції порівняно з минулими роками зріс, однак це не скасовує потреби у зверненні уваги до деформації працівників правоохоронних органів у соціальній сфері.

Деформація також впливає і на особисту сферу поліцейського, серед ії наслідків виокремлюють професійну заангажованість та вигорання; відсутність бажання професійного росту й навчання; погіршення психічного здоров'я; незадоволеність собою й оточенням тощо $[15$, c. 14$]$.

Особливу увагу слід звернути на деформацію у професійно-службовій сфері, адже саме вона чинить вплив на стан дотримання прав людини. Так, наслідками такої деформації є зниження ефективності виконання службової діяльності; порушення службової дисципліни й законності; прояви девіантної поведінки на службі та поза нею; затримка професійного розвитку; позаслужбові стосунки [15, с. 14]. 
Основними психологічними детермінантами професійної деформацій працівника правоохоронного органу є безпосередньо сама професійна діяльність, а також фактори, пов'язані зі змістом, організацією, умовами службової діяльності та окремими оперативно-службовими завданнями - зокрема, із фізичними та психологічними перевантаженнями; наявністю владних повноважень та рівнем контролю за правомірністю їх застосування; станом соціально-правового захисту; низькою довірою громадян до органу. Соціальне оточення працівника теж вважається детермінантом деформації через можливу некомпетентність керівництва (ригідність, упередженість, грубість), несприятливий соціально-психологічний клімат у колективі тощо [15, с. 13].

Варто не забувати і про детермінанти суб'єктивного характеру, які пов’язані з індивідуальнопсихологічними, особистісними характеристиками особи. Це - недостатня морально-вольова надійність; низька психологічна стійкість і витривалість; недостатня соціально-психологічна культура й підготовленість; неадекватна професійна мотивація; жорсткі, упереджені професійні стереотипи й установки; схильність до неконтрольованого вживання алкоголю й зловживання ним [15, с. 13]. Такі детермінанти можуть слугувати попереджувальними сигналами як для самого працівника, так і для його колег та керівництва.

Говорячи про причини професійної деформації, варто навести і певні положення із праць Р. Конечного та М. Боухала, які видаються слушними. Так, схильність до деформації особливо часто спостерігається у певних професіях, представники яких мають підлеглих і $€$ важкоконтрольованими владою. Від рішень і волі цих людей залежить гідність, існування, свобода і навіть здоров'я та життя інших людей, як це буває, наприклад, у вчителів, суддів, військовослужбовців, працівників держбезпеки, а також медичних працівників. Володіння владою призводить до громадської та психічної деформації, особливо у тих випадках, коли відсутні ефективні зворотні зв'язки - громадський контроль, критика і можливість позбавити носія деформації влади [18]. Схожої позиції притримується і С.П. Безносов, зазначаючи, що характер деформації може визначати не тільки професія, але й високе посадове становище. Володіння владою може призводити до деформації, коли відсутні ефективні зворотні зв'язки - громадський контроль та критика [6].

Отже, явище професійної деформації характерне для представників всіх видів професій. Однак працівники правоохоронних органів насамперед можуть піддаватися професійній деформації. Поява такого складного феномену зумовлена великою кількістю причин, серед яких виокремлюють адміністративні, організаційні, соціальні, політичні, моральні та інші причини. Однією з причин, яка призводить до перевищення чи зловживання владою поліцейським, застосування ним насильства та порушення прав людини, є професійна деформація. Така діяльність впливає не лише на зростання рівня злочинності, зниження рівня довіри до поліції, й на ситуацію із дотриманням прав людини. Вважаю, що встановлення деонтологічних стандартів поліцейської діяльності потребує ретельного концептуального осмислення, доктринального визначення та нормативного закріплення, адже в положеннях чинного законодавства в контексті діяльності поліції досі немає такої категорії, як професійне вигорання працівника. Позитивним прикладом має бути досвід зарубіжних країн, таких як Люксембург, Нідерланди, Німеччина, Ірландія, США, Франція та інші, де на законодавчому рівні прийнято кодекси деонтологічної поведінки поліцейських. Питання, пов'язані із професійною деформацією працівників правоохоронних органів, завжди мають бути на порядку денному. Попередження, усунення та протидія їй мають бути одним із завдань правоохоронних органів та підтримуватися державою і суспільством.

\section{Використана література:}

1. Конституція України: Закон України від 28.06.1996 р. № 254к/96-ВР / Верховна Рада України. Відомості Верховної Ради України. 1996. № 30. Ст.141.

2. Про Національну поліцію: Закон України від 02.07.2015 p. № 580-VIII / Верховна Рада України. URL: https://zakon.rada.gov.ua/laws/show/580-19\#Теxt (дата звернення: 06.11.2021).

3. Гула Л.Ф. Заходи щодо запобігання порушення законності та прав і свобод людини працівниками органів внутрішніх справ. Вісник Луганського держсавного університету внутрішніх справ імені Е.О. Дідоренка. № 2. С. 173-180. 
4. Хоржевська I.М., Царапора В.В. Особливості професійної деформації особистості військових та міліціонерів. Науковий вісник Миколаӥвського державного університету імені В. О. Сухомлинського. Серія: Психологічні науки. 2013. Т. 2. Вип. 10. С. 312-315. URL: http://nbuv.gov.ua/UJRN/ Nvmdups_2013_2_10_62 (дата звернення: 02.11.2021).

5. Боднар В.С. Детермінанти професійної деформації працівників Національної поліції України. Юридичний бюлетень. 2018. Вип. 8. С. 283-291. URL: http://www.lawbulletin.oduvs.od.ua/ archive/2018/8_2018/43.pdf (дата звернення: 02.11.2021).

6. Безносов С.П. Профессиональная деформация и воспитание личности. Психологическое обеспечение социального развития человека. СПб.: Речь, 2004. 271 с.

7. Зеер Э.Ф. Психология профессий: учебное пособие. М.: Академический проект. Екатеринбург: Деловая книга, 2003. 336 с.

8. Маркова А.К. Психология профессионализма. М.: Знание, 1996. 308 с.

9. Вітик Ю.І. Принцип дотримання прав людини в діяльності Національної поліції України: стан наукового дослідження. Підприємництво, господарство і право, 2021. № 5. C. 116-121. URL: http://pgp-journal.kiev.ua/archive/2021/4/32.pdf (дата звернення: 03.11.2021).

10. Національний моніторинг незаконного насильства в поліції в Україні у 2020 році / Д. Кобзін, А. Черноусов, С. Щербань; Харківський інститут соціальних досліджень; Харківська правозахисна група. Харків: ТОВ «Видавництво «Права людини», 2020. 64 c. URL: http://library.khpg.org/ index.php?id=1602823656 (дата звернення: 02.11.2021).

11. Захаров Є.Ю. Реформування органів внутрішніх справ та права людини. URL: https://helsinki.org.ua/mvs-ta-prava-lyudyny-e-zaharov (дата звернення: 01.11.2021).

12. Кирбят'єв О.О. Професійна деформація особистості працівника правоохоронного органу як причина неналежного виконання своїх обов’язків. Юридичний вісник. 2019. № 4. С. 204-210. URL: http://yurvisnyk.in.ua/v4_2019/32.pdf (дата звернення: 05.11.2021).

13. Медведев В.С. Психология профессиональной деформации сотрудников органов внутренних дел : дис. ... д-ра психолог. наук : 19.00.06 . Киев, 1999. 412 с.

14. Климов Е.А. Психология профессионала: монография. Москва: Изд-во «Институт практической психологии», 1996. 400 с.

15. Професійно-психологічна підготовка працівників Національної поліції. Міністерство внутрішніх справ України, Одеський державний університет внутрішніх справ. 2017. 18 с. URL: http://oduvs.edu.ua/wp-content/uploads/2016/09/lek-1_2017-PPPPPNP.pdf (дата звернення: 07.11.2021).

16. Кісіль 3.Р. Професійна деформація працівників органів внутрішніх справ України: історіографія та феноменологія. Науковий вісник Львівського державного університету внутрішніх справ. Серія психологічна. 2014. Вип. 2.-С.33-44. URL: http://nbuv.gov.ua/UJRN/Nvldu_2014_2_6(дата звернення: 02.11.2021).

17. Борисова С.Е. Профессиональная деформация сотрудников милиции и ее личностные детерминанты: автореф. дис. на соиск. уч. ст. канд. психол. наук. Москва, 1998. 204 с.

18. Конечный Р., Боухал Я. Психология в медицине. М.: Прага, 1983. С. 253-254.

\section{References:}

1. Konstytutsiya Ukrainy: Zakon Ukrainy vid 28.06.1996 r. № 254k/96-VR/ [The Constitution of Ukraine: Law of Ukraine as of 28.06.1996 No. 254k/96-VR]. Verhovna Rada Ukrainy. Vidomosti Verkhovnoi Rady. 1996. № 30. 141 p. [in Ukrainian].

2. Pro Nacionalnu policiyu: Zakon Ukrainy vid 02.07.2015 r. № 580-VIII [About National police: Law of Ukraine as of 02.07.2015 No. 580-VIII]. Verhovna Rada Ukrainy. URL: https://zakon.rada.gov.ua/ laws/show/580-19\#Text. [in Ukrainian].

3. Hula L.F. (2015) Zahodi shodo zapobigannya porushennya zakonnosti ta prav i svobod lyudini pracivnikami organiv vnutrishnih sprav [Measures in relation to prevention of violation of legality and rights and freedoms of man by the workers of organs of internal affairs] Visnik Luganskogo derzhavnogo universitetu vnutrishnih sprav imeni E.O. Didorenka. № 2. S. 173-180. [in Ukrainian].

4. Khorzhevska I.M., Carapora V.V. (2013) Osoblivosti profesijnoyi deformaciyi osobistosti vijskovih ta milicioneriv [Features of professional deformation of personality of soldiery and militiamen]. Naukovij visnik Mikolayivskogo derzhavnogo universitetu imeni V.O. Suhomlinskogo. Seriya: Psihologichni nauki. T. 2. Vol. 10. S. 312-315. [in Ukrainian]. 
5. Bodnar V.Ye. (2018) Determinanti profesijnoyi deformaciyi pracivnikiv Nacionalnoyi policiyi Ukrainy [Determinants of professional deformation of police officers of the National police of Ukraine]. Yuridichnij byuleten. Vol. 8. S. 283-291. [in Ukrainian].

6. Beznosov S.P. (2004) Professional'naja deformacija i vospitanie lichnosti. [The professional deformation and personal education]. Psihologicheskoe obespechenie social'nogo razvitija cheloveka. Vol. 13, s. 34-45. SPb., Rech. [in Russian].

7. Zeer E.F. (2003) Psihologiya professij: uchebnoe posobie. [Psychology of profession]. M.: Akademicheskij proekt. Ekaterinburg: Delovaya kniga. 336 s. [in Russian].

8. Markova A.K. (1996) Psihologiya professionalizma. [Psychology of professionalism]. M.: Znanie, 308 s. [in Russian].

9. Vityk Yu.I. Princip dotrimannya prav lyudini v diyalnosti Nacionalnoyi policiyi Ukrayini: stan naukovogo doslidzhennya. [Principle of respect for human rights in activities of the National Police of Ukraine: state of scientific research]. Pidpriyemnictvo, gospodarstvo i pravo, 2021. № 5. S. 116-121. [in Ukrainian].

10. Nacionalnij monitoring nezakonnogo nasilstva $\mathrm{v}$ policiyi $\mathrm{v}$ Ukrayini u 2020 roci D. Kobzin, A. Chernousov, S. Sherban (2020). [The National monitoring of use of force in police of Ukraine, 2020]. Harkivskij institut socialnih doslidzhen; Harkivska pravozahisna grupa. Harkiv: TOV «Vidavnictvo «Prava lyudini», 64 s. [in Ukrainian].

11. Zaharov Ye.Yu. Reformuvannya organiv vnutrishnih sprav ta prava lyudini. [The reform of internal affairs agencies and human rights]. [in Ukrainian].

12. Kyrbiatiev O.O. (2019) Profesijna deformaciya osobistosti pracivnika pravoohoronnogo organu yak prichina nenalezhnogo vikonannya svoyih obov'yazkiv. [Professional deformation of the personality of the law enforcement authority as a cause of the inadmissible fulfillment of their duties]. Yuridichnij visnik. № 4. S. 204-210. [in Ukrainian].

13. Medvedev V.S. (1999) Psihologiya professionalnoj deformacii sotrudnikov organov vnutrennih del. [Psychology of professional deformation of internal affairs officers]. Dis. ... d-ra psiholog. nauk : 19.00.06 . Kiev. 412 s. [in Russian].

14. Klimov E.A. (1996) Psihologiya professionala: monografiya. [Psychology of professional]. Moskva: Izd-vo «Institut prakticheskoj psihologii». $400 \mathrm{~s}$. [in Russian].

15. Profesijno-psihologichna pidgotovka pracivnikiv Nacionalnoyi policiyi (2017). [Professional and psychological training of National police officers]. Ministerstvo vnutrishnih sprav Ukrayini, Odeskij derzhavnij universitet vnutrishnih sprav. $18 \mathrm{~s}$. [in Ukrainian].

16. Kisil Z.R. (2014) Profesijna deformaciya pracivnikiv organiv vnutrishnih sprav Ukrayini: istoriografiya ta fenomenologiya. [Professional deformation of law enforcement workers of Ukraine: historiography and phenomenology]. Naukovij visnik Lvivskogo derzhavnogo universitetu vnutrishnih sprav. Seriya psihologichna. Vol. 2. - S. 33-44. [in Ukrainian].

17. Borisova S.E. (1998) Professionalnaya deformaciya sotrudnikov milicii i ee lichnostnye determinanty [The professional deformation of militia officers and its personal determinants]. avtoref. dis. na soisk. uch. st. kand. psihol. nauk. Moskva, 204 s. [in Russian].

18. Konechnyj R., Bouhal Ya. (1983) Psihologiya v medicine. [Psychology in medicine]. M.: Praga. S. 253-254. [in Russian].

Chornyi H. O., Savchenko R. I. Problem statement of professional deformation of police officers of the National police of Ukraine as a cause of human rights violation and use of force

The article is devoted to the study of an important psychological phenomenon in the activities of law enforcement agencies, namely, professional deformation.

It is proved that the essential prerequisite for effective police action is the mandatory observance of the rule of law and protecting human rights. It is noted that this would have an impact not only on the state of respect for human rights, but also on the level of trust to the police. The recognition by the public opinion police is the main criteria for assessing the work of these bodies.

It is emphasized that the professional deformation is inherent in every profession and is an inevitable and undesirable phenomenon. It is established that the profession of law enforcement officer is one of the most vulnerable to the formation and development of professional deformation. In particular, due to the special features of such activities - working conditions, responsibilities, physical and mental stress, conflict situations, etc.

It has been hypothesized that one of the reasons that could lead to a use of force of a law enforcement officer is the professional deformation of the personality of such an employee. The phenomenon 
of professional deformation of the law enforcement officer personality is considered as one of the reasons for human rights violations and committing the crime.

It was found out that professional deformation is caused by a whole complex of social, political, moral reasons, administrative and other reasons. Factors that can lead to professional deformation of the law enforcement officer are identified. The influence of the professional deformation not only in professional activity of the law enforcement officer, but also in private life and inner circle is highlighted. Approaches to the definition of professional deformation phenomenon are synthesized.

It was summarized that the efforts to the prevention and elimination of the professional deformation as a general phenomenon should be directed not only by the law enforcement agencies, but also effort of both society and the State.

Key words: professional deformation, law enforcement officer, human rights, use of force. 
УДК 343.98:343.326

DOI https://doi.org/10.31392/NPU-nc.series18.2021.36.14

Чорний Г. О.

\section{ОСОБЛИВОСТІ ЗАСТОСУВАННЯ ГЕНЕТИЧНОГО ФІНГЕРПРИНТА ПІД ЧАС РОЗСЛІДУВАННЯ ЗЛОЧИНІВ ТЕРОРИСТИЧНОЇ СПРЯМОВАНОСТІ}

Злочини терористичної спрямованості відносяться до тяжких та особливо тяжких кримінальних правопорушень, розслідування яких здебільшого залежить від ефективності проведення слідчих розшукових гласних дій на початковому етапі. До таких дій належить насамперед огляд місия події, метою якого є виявлення та фіксація відомостей щодо обставин вчинення кримінальних правопорушень. Серед необхідних та важливих зазначених обставин важливу роль відіграють сліди вчинення злочинів терористичної спрямованості.

Особливу зацікавленість та криміналістичну «привабливість» мають біологічні мікросліди людини та можливість ї̈ ідентифікаиії за зразками ДНК - генетичний фінгерпринтинг. У теорії криміналістики під мікрослідами розуміють мікрооб'єкти - речові докази, які мають малий розмір (дрібні тіла), а також малу кількість речовин і матеріалів, - невидимі або слабо видимі за нормальних умов спостереження. Розглядаючи у статті сліди біологічного походження - виділення організму та/або частини органів і тканини, слід зазначити, що до них належать насамперед клітини, кров, сперма, волосся, слина, потові та жирові нашарування, сеча, а також нігті, кістки, частини шкіри, м'язової тканини та інших внутрішніх органів.

У статті детально розглядаються питання застосування методу вузлового огляду об' єктів носіїв слідів біологічного походження (далі - СБП) та пропонується такий алгоритм: можливість дослідження СБП; особливості вилучення конкретного СБП; особливості отримання зразків для експертного дослідження; коло питань під час призначення судової молекулярно-генетичної експертизи.

Особливу увагу автор приділяє правилам, вимогам до вилучення слідів біологічного походження: вилучення СБП здійснюється виключно після їх опису у протоколі слідчої дї̈ та проведення фотота відеозйомки; до вилучення СБП необхідно приступити як можна швидше після їх утворення та/або виявлення; невеликі об 'єкти-носії слід вилучати разом із предметом, а з великогабаритних робити змиви; усі СБП повинні бути упаковані таким чином, щุоб їх можна було вилучити без порушення упаковки.

Ключові слова: злочини терористичної спрямованості, мікросліди, сліди біологічного походження людини, генетичний фінгерпринтінг.

Вчинення злочинів терористичної спрямованості відповідно до частини 1 ст. 11 та частини 6 ст. 12 КК України належить до найбільш суспільно небезпечних кримінальних правопорушень. Під час проведення досудового слідства, особливо на початковому етапі, слідчі, прокурори все частіше стикаються з тим, що злочини терористичної спрямованості мають ретельну підготовку, підбір учасників та знарядь вчинення кримінального правопорушення. Особливе значення на початковому етапі досудового розслідування під час проведення огляду місця події мають мікросліди. У теорії й практиці криміналістики використовуються поняття «мікрочастинки», «мікросліди», «мікрооб’єкти» та інші.

Під мікрооб'єктами як речовими доказами слід розуміти різноманітні дрібні тіла, а також малу кількість речовин і матеріалів, що невидимі або слабо видимі за нормальних умов спостереження. Таким чином, малий розмір, труднощі виявлення за звичайних умов (нормальний зір, звичайне освітлення) - основні ознаки, які відрізняють мікрооб'єкти від маси інших об'єктів, визначають специфіку роботи з ними. Наведене визначення не виключає, зрозуміло, використання під час експертних досліджень спеціальних нормованих градацій проб речовини, мікропрепаратів тощо [4, с. 39]

Невидимими $є$ такі, які за нормальних умов (звичайне освітлення, нормальні суб'єктивні дані спостерігача) зором не сприймаються. Вони можуть бути невидимими внаслідок малих розмірів, що лежать за порогом гостроти зору людини, а також через малу відмінність за кольором та іншими властивостями від навколишнього середовища. 
Слабко видимі мікрооб'єкти визначаються тим, що факт їх наявності за звичайних умов зором може бути встановлений, але вивчення ознак без спеціальних технічних засобів і методів неможливе. У цьому разі сприймається візуальний сигнал лише про наявність об'єкта, необхідна інформація про його властивості неозброєному зору недоступна.

Найбільш загальною підставою для класифікації мікрочастинок $є$ форма їхнього матеріального втілення (організація матеріальної субстанції). За цією підставою мікрочастинки діляться на: 1) одиничні матеріальні утворення - окремі фізичні тіла, що володіють стійкою формою; 2) речовини (матеріали), що не мають форми одиничного тіла (рідини, порошкоподібні речовини).

За безпосереднім джерелом походження мікрооб'єкти класифікуються на дві великі групи: частини природного походження (від природних об'єктів); частини, які відокремилися від об'єктів, значною мірою оброблених або штучно створених людиною. У першій групі необхідно виділити чотири підгрупи: мікрооб'єкти, які відокремилися від організму людини (обривки волосся, шматочки шкіри, уламки нігтів, мікрокількості різних виділень тощо); мікрооб'єкти від тварин (волоски вовни, пуху тощо); мікрочастинки від рослин (насіння, частки трав і деревних рослин, пилок тощо); мікрооб'єкти мінерального характеру (грунтові частки, частки твердих копалин, мікросліди природної нафти). Ці підгрупи визначають спеціалізацію експертизи, що досліджує відповідні мікрооб'єкти, вибір експертної установи для напряму об'єктів (криміналістична, судово-медична тощо). У другу групу входять тіла й речовини, що відокремились у вигляді мікрочастинок від оброблених або штучно створених об'єктів (виробів). Частки цієї групи можна умовно розподілити за основними компонентами складу на три підгрупи: мікрочастинки неорганічного складу (осколки скла, кераміки, мікрооб'єкти виробів із металів, деякі будівельні матеріали, неорганічні хімічні речовини); мікрооб'єкти з основним органічним складом (волокна з вовняної й рослинної пряжі, шматочки дерев'яних виробів, паперу, частки тютюну, мікросліди паливно-мастильних матеріалів, мікросліди хімічних матеріалів та інші органічні речовини); мікрочастинки змішаного складу (волокна від комбінованих ниток, частки автоемалі). Класифікація мікрооб'єктів за складом має значення для правильної побудови методики їх подальшого експертного дослідження. Під час розгляду мікрооб'єктів у сукупності з об'єктами-носіями їх диференціюють за слідоутворюючим об'єктом та видом контактного зв'язку з носієм: накладення; включення; нашарування [ 6, с. 61, 73].

Останнім часом, із розвитком науково-технічного процесу та втіленням його в процес розслідування кримінальних правопорушень, важливе значення мають процеси ідентифікації людини за її зразками біологічного походження. Особливу зацікавленість та, так би мовити, «криміналістичну привабливість» становить генетичний фінгерпринтинг - ідентифікація людини за кодом ДНК. Необхідно звернути увагу, що починаючи з 80-х років минулого століття наукові досягнення дозволили використовувати ДНК-матеріал для ідентифікації особистості. Перший патент для використання варіації ДНК у криміналістиці був поданий доктором Джефрі Гласбергом ще у 1983 році. Незалежно від цього Алек Джеффріс, працюючи на кафедрі генетики університету Лестера, разом із Пітоером Гіллом та Дейвом Верреттом, працівниками Служби криміналістичної науки (FSS), розробили у 1984 році процес профілювання за ДНК.

Зазначений метод вперше був застосований під час розслідування вбивства двох підлітків, які були згвалтовані та вбиті в Нарборо і Лестерширі у 1983 та 1986 роках. Шляхом ідентифікації близько 5000 зразків крові, отриманих добровільно від місцевих чоловіків, було висунуто обвинувачення та засуджено Коліна Пітчфорка, який залишив свій ДНК на обох місцях вчинення вбивств.

Код ДНК міститься в слідах біологічного походження - виділеннях організму та/або частини органів і тканини. До них належать насамперед клітини, кров, сперма, волосся, слина, потожирові нашарування, сеча, а також нігті, кістки, частини шкіри, м'язової тканини та інших внутрішніх органів. Досліджуючи більш детально зазначені об'єкти - носії слідів біологічного походження (далі СБП), доцільно це зробити за таким алгоритмом: можливість дослідження СБП; особливості вилучення конкретного СБП; особливості отримання зразків для експертного дослідження; коло питань під час призначення судової молекулярно-генетичної експертизи. 
Виявлення мікрослідів здійснюється послідовно та планомірно, відповідно до тактичних комбінацій відповідної слідчої дії. Найбільш поширеним методом виявлення мікрослідів науковці та експерти вважають метод вузлового огляду об'єктів, сутність якого полягає у тому, що кожен вузол включає у себе окремі об'єкти (ділянки місцевості, предмети тощо), які послідовно досліджуються один за одним. Детальний огляд об'єктів супроводжується використанням статичного та динамічних методів [5, с. 123].

Особливу увагу слід приділити загальним правилам вилучення слідів біологічного походження: вилучення СБП здійснюється виключно після їх опису у протоколі слідчої дії та проведення фото- та відеозйомки і здійснюється на завершальній стадії слідчої дії, що дозволяє виявити механізм вчинення злочину та утворення слідів; до вилучення СБП необхідно приступити якомога швидше після їх утворення та/або виявлення; невеликі об'єкти-носії слід вилучати разом із предметом, а з великогабаритних робити змиви; усі СБП повинні бути упаковані таким чином, щоб їх можна було вилучити без порушення упаковки. Під час виявлення слідів крові звертається увага на величину і форму слідів, що може свідчити про механізм слідоутворення та обставини вчинення кримінального правопорушення. Однотипні елементарні сліди крові зустрічаються у вигляді одиночних або групових (сукупності) слідів. Розрізняють такі форми елементарних слідів крові, як: калюжа - від витікання великої маси крові; плями від бризок - від краплі крові, що падає під дією сили ваги, або пляма від краплі крові, що одержала додаткову кінетичну енергію; потік - від великого обсягу або великих крапель крові, що стікаються під дією сили ваги; помарка - від зіткнення (дотику) закривавленого предмету або частини тіла з будь-якою поверхнею; відбиток - від повного зіткнення закривавленого предмету та/або частини тіла з якою-небудь поверхнею.

Вилучення слідів крові здійснюється шляхом зіскобу або змиву. До кола питань, які вирішує судова молекулярно-генетична експертиза, слід віднести такі: 1. Чи є кров людини на об'єкті, який наданий на дослідження? 2. Якщо так, то чи можливо встановити іiї генетичні ознаки (ДНК-профіль)? 3. Прошу встановити генетичні ознаки (ДНК-профіль) зразка крові підозрюваного П.; 4. Чи зберігаються генетичні ознаки крові, виявленої на наданому для дослідження об’єкті, з генетичними ознаками (ДНК-профілем) зразка крові підозрюваного П.?

Основна частина слідів, залишених на гладких поверхнях, відноситься до потожирових слідів. Піт - продукт потових шкірних залоз, які разом із сальними $є$ похідними шкірного епідермісу і являють собою залозистий апарат шкіри. Це безбарвна водяниста рідина, що містить значну кількість сечовини і солей. До її складу входять сечова кислота, креатини, летучі жирні кислоти і мінеральні солі. Піт не містить ядровмісних клітин. Жиропіт - основна частина сліду, залишеного на гладкий поверхні пальцями рук та долонь. Піт і жиропіт визначеної особи має однакову із кров'ю групову належність. Об'єкти зі слідами жиропоту (поту) вилучаються разом з об'єктом-носієм. Якщо об'єкт зі слідами поту та /або його частину вилучити неможливо, здійснюється змив. Змив роблять на фрагменті марлі, яку перед упакуванням обов’язково ретельно висушують при кімнатній температурі без впливу сонячного світла.

Слина являє собою секрет залоз людини, що виділяється в стільникову порожнину і бере участь у травленні, є мутнуватою рідиною через наявність клітинних елементів. Слину найчастіше виявляють на недопалках сигар і цигарок, носовиках, поштових марках, конвертах, столовому посуді, горлечках пляшок та недоїдках. До кола питань, які вирішує судова молекулярно-генетична експертиза під час виявлення слідів біологічного походження, які можуть містити клітини з ядрами, слід віднести такі: 1. Чи є на об'єкті клітини з ядрами?; 2. Якщо так, то чи можливо встановити їх генетичні ознаки (ДНК-профіль)?; 3. Прошу встановити генетичні ознаки (ДНК-профіль) зразка букального епітелію підозрюваного П.; 4. Чи збігаються генетичні ознаки клітини з ядрами, виявлених на наданому для дослідження об'єкті, з генетичними ознаками (ДНК-профілем) зразка букального епітелію підозрюваного П.?

Волосся розглядається як рогові утворення шкіри, що покривають майже всю її поверхню. Розрізняють довге товсте волосся голови, бороди і вусів, пахвових западин, лобка і статевих органів, щетинисте волосся брів, вій, носового входу і зовнішнього слухового проходу, пушкове волосся, що покриває всю іншу шкіру. У волоссі розрізняють стрижень, що виступає 
над поверхнею шкіри і складається із серцевини, коркової речовини і кутикули, та занурений у шкіру корінь, який закінчується стовщенням - цибулиною. Волосся вилучається разом із предметом, на якому воно виявлено, або окремо. Під час вилучення важливо не припускатися пошкоджень волосся. Волосся, яке виявлене в різних місцях під час огляду місяця події, упаковується в окремі конверти із зазначенням місць виявлення. Якщо волосся виявлено у слідах засохлої крові, воно вилучається разом із кров’ю або з частинами предмета-носія.

Вилучення зразків волосся рекомендується здійснювати шляхом виривання його пальцями у трупів чи зрізання ножицями у живих осіб із передньої, середньої і бокової частин голови (лобної, тьмяної, потиличної, правої і лівої скроневих ділянок). У разі потреби беруть у такий же спосіб волосся із бороди, вусів, бакенбардів, брів, лобка тощо. Зразки волосся в кількості 15-30 штук із кожної ділянки кладуть в окремі пакети чи пробірки і супроводжують відповідними надписами про місце відібрання зразків [1, с. 47].

Розглядаючи питання призначення судової молекулярно-генетичної експертизи (СМГЕ) під час виявлення волосся людини слід насамперед зазначити, що остання призначається після проведення судової експертизи волосся, у висновку якої повинна міститися інформація про те, що об'єкти є волоссям, яке належить людині та є придатним для проведення СМГЕ ядерної ДНК. У такому разі на вирішення СМГЕ можливо поставити таке питання: «Чи можливо встановити генетичні ознаки (ДНК-профіль) волосини (волосся) людини згідно з висновком судового експерта, який проводив первинне дослідження?» У ситуації, коли разом із волоссям на експертизу направляється зразок особи, приблизне коло питань може бути таким: 1. Прошу встановити генетичні ознаки (ДНК-профіль) зразка (крові / букального епітелію) особи. 2. Чи можливо встановити генетичні ознаки (ДНК-профіль) волосини (волосся) людини згідно 3 висновком судового експерта, який проводив первинне дослідження? 3. Чи збігаються генетичні ознаки (ДНК-профіль) волосини (волосся) людини, згідно з висновком судового експерта, який проводив первинне дослідження, з генетичними ознаками (ДНК-профілем) зразка (крові / букального епітелію) особи?

Кістки, частини шкіри, м'язової тканини та інші внутрішні органи досить рідко зустрічаються під час огляду місця події як мікросліди. Найчастіше вони виявляються на знаряддях вчинення злочинів терористичної спрямованості - транспортних засобах, якщо вони були використані як об'єкти та/або предмети злочинного посягання, предметах обстановки місця вчинення злочину, в піднігтьовому вмісті потерпілого та терориста [3, с. 45]. Необхідно звернути увагу, що до комплексного дослідження піднігтьового вмісту рекомендовано спочатку провести дослідження на наявність текстильних волокон та інших мікрооб'єктів, а потім цитологічну експертизу. Із трупа, який має гнилісні зміни, у тому числі й під час ексгумації, доцільно направляти найменш змінені тканини і трубчасті кістки з епіфізами. Дії високої температури негативно впливають на виділення і подальше дослідження ДНК. У таких випадках на дослідження необхідно направляти м'язи, в яких менше виражені гнилісні зміни. Під час вчинення злочинів терористичної спрямованості шляхом використання вибухового пристрою та/або вибухових речовин, якщо є залишки ушкоджених тіл, частини трупного матеріалу - м'язи, шматочки шкіри, кістки, частини внутрішніх органів тощо, останні вилучаються до контейнеру (скляні або пластикові банки чи пробірки), відповідним чином опечатуються й описуються [7, с. 89, 90].

Розглядаючи питання відібрання біологічних зразків, слід звернути увагу, що дії слідчого та прокурора регламентуються статтями 241 та 245 КПК України на підставі постанови вищезазначених посадових осіб. Перед початком відібрання біологічних зразків особі пред'являють постанову та пропонують добровільно надати біологічні зразки. Найпоширенішими способами отримання біологічних зразків в особі є відбирання крові, слини та/або букального епітелію. У разі відмови особи добровільно надати біологічні зразки сторона кримінального провадження звертається до слідчого судді з клопотанням про відібрання біологічних зразків примусово.

Процесуальна форма передбачає, що слідчий та прокурор виконують роботу з виявлення, фіксації та вилучення мікрослідів біологічного походження, однак мають на підставі ст. 69 та 71 КПК України залучати експертів та спеціалістів. [2, с. 57, 59]. 


\section{Використана література:}

1. Перлін С.І., Шевцов С.О., Косміна Н.М. Огляд місця події: виявлення та вилучення об'єктів біологічного походження: методичні рекомендації. ДНДЕКЦ МВС України. Харків: ФОП Чальцев О.В., 2009. 100 с.

2. Прокопенко Н.А. Проблемы использования микроследов в правоохранительной деятельности. III Международная научно-практическая конференция, 2008. С. 374-376.

3. Марчук А.И. Использование микрообъектов при расследовании преступлений против личности. Теоретические и практические проблемы обеспечения раскрытия и расследования преступлений криминалистическими методами и средствами: сборник научных трудов. Киев, 1992. 237 с.

4. Бершацкий Е.М. Проблемы микроследов в современной криминалистике. Криминалистика $u$ судебная экспертиза: республиканский межведомственный сборник научных и научно-методических работ. 1977. Вип. 14.

5. Клименко Н.И. Использование микрообъектов при расследовании преступлений. Киев: КГУ, $1984.93 \mathrm{c}$.

6. Практикум з криміналістики: навчальний посібник / В.Ю. Шепітько та ін.; за ред. В.Ю. Шепітька. Київ: Ін Юре, 2013. 128 с.

7. Особливості збирання у досудовому провадженні біологічних слідів людини: методичні рекомендації / М.В. Нечеснюк та ін. Київ: Національна академія внутрішніх справ, 2016. 44 с.

\section{References:}

1. Perlin S.I., Shevcov S.O., Kosmina N.M. (2009) Oglyad miscya podiyi: viyavlennya ta viluchennya ob'yektiv biologichnogo pohodzhennya: metodichni rekomendaciyi [Site overview: detection and removal of objects of biological origin: guidelines]. DNDEKC MVS Ukrainy. Harkiv: FOP Chalcev O.V., 2009. 100 s. [in Ukrainian].

2. Prokopenko N.A. (2008) Problemy ispolzovaniya mikrosledov v pravoohranitelnoj deyatelnosti [Problems of using microtrace in law enforcement]. III Mezhdunarodnaya nauchno-prakticheskaya konferenciya, S. 374-376. [in Russian].

3. Marchuk A.I. (1992) Ispolzovanie mikroobektov pri rassledovanii prestuplenij protiv lichnosti [The use of micro-objects in the investigation of crimes against the person]. Teoreticheskie i prakticheskie problemy obespecheniya raskrytiya $i$ rassledovaniya prestuplenij kriminalisticheskimi metodami $i$ sredstvami: sbornik nauchnyh trudov. Kiev. 237 s. [in Russian].

4. Bershackij E.M. (1977) Problemy mikrosledov v sovremennoj kriminalistike [Problems of microtraces in modern forensics]. Kriminalistika i sudebnaya ekspertiza: respublikanskij mezhvedomstvennyj sbornik nauchnyh i nauchno-metodicheskih rabot. Vol. 14. [in Russian].

5. Klimenko N.I. (1984) Ispolzovanie mikroobektov pri rassledovanii prestuplenij [The use of microobjects in the investigation of crimes.]. Kiyiv: KGU. 93 s. [in Russian].

6. Praktikum z kriminalistiki: navchalnij posibnik (2013) [Workshop on sciences of criminalistic: training manual] / V.Yu. Shepitko ta in.; za red. V.Yu. Shepitka. Kiyiv: In Yure. 128 s. [in Ukrainian].

7. Osoblivosti zbirannya u dosudovomu provadzhenni biologichnih slidiv lyudini: metodichni rekomendaciyi (2016) [The features of biological traces removal in the pre-trial proceedings: methodological recommendations] / M.V. Nechesnyuk ta in. Kiyiv: Nacionalna akademiya vnutrishnih sprav. 44 s. [in Ukrainian].

\section{Chornyi $G .0$. The features of the use of genetic fingerprinting in the investigation of terrorist crimes}

Terrorist crimes are serious and especially serious criminal offenses, investigation which in most cases depends on the effectiveness of investigative investigative actions at the initial stage. Such actions include, first of all, an inspection of the scene, the purpose of which is to identify and record information on the circumstances of the commission of criminal offenses. Among the necessary and important of these circumstances, traces of terrorist crimes play an important role.

Special interest and forensic "attractiveness" attract biological microtrace of human compartments and the possibility of its identification by DNA samples - genetic fingerprinting. In the theory of criminology, micro-traces are understood as micro-objects - physical evidence that has a small size (small bodies), as well as a small amount of substances and materials - invisible or faintly visible under normal conditions of observation. Considering in this article traces of biological origin - the selection of the body and / or parts of organs and tissues, it should be noted that they include, first of all, 
cells, blood, semen, hair, saliva, sweat and fat, urine, and as well as nails, bones, skin, muscle tissue and other internal organs.

The article considers in detail the application of the method of nodal inspection of objects - carriers of traces of biological origin (hereinafter SBP) and proposes the following algorithm: - the possibility of studying SBP; - features of removal of a specific SBP; - features of receipt samples for expert research; range of issues in the appointment of forensic molecular genetic examination.

The author pays special attention to the rules, requirements for the removal of traces of biological origin, which include: - removal of SBP is carried out only after their description in the protocol of the investigative action and photo and video shooting; - removal of SBP should begin as soon as possible after their formation and / or detection; - small objects - media should be removed together with the object, and large ones should be washed away; - all SBPs must be packed in such a way that they can be removed without disturbing the packaging.

Key words: terrorist crimes, trace traces, traces of human biological origin, genetic fingerprinting. 


\section{НАШІ АВТОРИ}

АНТОЩУК АНДРІЙ
ОЛЕКСАНДРОВИЧ

БЛІХАР МАРІЯ МИРОНІВНА

ГЛУЩЕНКО МИКОЛА

ПАВЛОВИЧ

ГРИНЕНКО КАТЕРИНА

BIKTOPIBHA

ЗАЯЦЬ ОЛЬГА СТЕПАНІВНА

ЗИЦИК СЕРГІЙ ГРИГОРОВИЧ

КАЛЕТНІК ГРИГОРІЙ
МИКОЛАЙОВИЧ

КОНЧАКОВСЬКА

ВАЛЕНТИНА ВАСИЛІВНА

МАКАРОВА ОЛЕНА

ВАСИЛІВНА

НАТАЛІЯ АДРІАНІВНА
БУКОВИНСЬКА

ОПОЛЬСЬКА НАТАЛЯ

МИХАЙЛІВНА кандидат юридичних наук, доцент кафедри криміналістики та судової медицини Національної академії внутрішніх справ absord@ukr.net

доктор юридичних наук, доцент, професор кафедри адміністративного та інформаційного права Інституту права, психології та інноваційної освіти Національного університету «Львівська політехніка»

blikharm@ukr.net

аспірант кафедри правознавства та галузевих юридичних дисциплін факультету політології та права Національного педагогічного університету імені М. П. Драгоманова paluch84@ukr.net

ад'юнкт кафедри криміналістики та судової медицини Національної академії внутрішніх справ

tymoshenko_k@ukr.net

кандидат юридичних наук, доцент кафедри цивільноправових дисциплін Львівського державного університету внутрішніх справ

zaiatsolha777@gmail.com

кандидат юридичних наук, доцент кафедри права Луцького національного технічного університету

sergeypravo@i.ua

доктор економічних наук, професор, академік Національної академії аграрних наук України, завідувач кафедри адміністративного менеджменту та альтернативних джерел енергії Вінницького національного аграрного університету

rector@vsau.org

кандидат юридичних наук, доцент кафедри правознавства і галузевих юридичних дисциплін соціально-правового факультету Національного педагогічного університету імені М. П. Драгоманова

valentina_kv@ukr.net

кандидат юридичних наук, доцент кафедри теорії та історії держави і права соціально-правового факультету Національного педагогічного університету імені М. П. Драгоманова

Elena_k_v@ukr.net

аспірант кафедри адміністративного права i процесу та митної безпеки Університету Державної фіскальної служби України natali410@gmail.com

доктор юридичних наук, доцент, завідувач кафедри права Вінницького національного аграрного університету Opolska@vsau.org 
САВЧЕНКО РЕГІНА ІГОРІВНА студентка VI курсу слідчо-криміналістичного інституту Національного юридичного університету України імені Ярослава Мудрого

\author{
СИЗОНЕНКО АНТОН \\ СТЕПАНОВИЧ
}

ТЕРЕХОВ ВІТАЛІЙ ЮРІЙОВИЧ

ТОМЛЯК ТАЇСА СЕРГІЇВНА

\author{
ХАРИТОНОВ РОМАН \\ ФЕЛІКСОВИЧ
}

\author{
ЧОРНИЙ ГЕННАДІЙ \\ ОЛЕКСІЙОВИЧ
}

sregina302@gmail.com

кандидат юридичних наук, доцент, Заслужений юрист України, перший заступник директора Департаменту персоналу Міністерства внутрішніх справ України my.post@meta.ua кандидат юридичних наук, адвокат terehov_dok@ukr.net аспірантка кафедри теорії та історії держави і права Національного педагогічного університету імені М. П. Драгоманова, старший викладач кафедри права Вінницького національного аграрного університету

tomlak.taya@gmail.com

кандидат юридичних наук, доцент кафедри міжнародного та європейського права факультету міжнародно-правових відносин Національного університету «Одеська юридична академія»

roman2012h@gmail.com

кандидат юридичних наук, доцент, доцент кафедри криміналістики Національного юридичного університету України імені Ярослава Мудрого

chernygennadiy@gmail.com 


\section{OUR AUTHORS}

ANTOSHCHUK ANDRII OLEKSANDROVYCH

BLIKHAR MARIIA

MYRONIVNA

CHORNYI HENNADII

OLEKSIIOVYCH

GLUSCHENKO MYKOLA PAVLOVYCH

HRYNENKO KATERYNA VIKTORIVNA

KALETNIK GRYGORII MYKOLAYOVYCH

KHARYTONOV ROMAN FELIKSOVYCH

KONCHAKOVSKA

VALENTYNA VASYLIVNA

MAKAROVA

OLENA VASYLIVNA

NATALIIA ADRIANIVNA BUKOVYNSKA

SAVCHENKO REHINA IHORIVNA
Candidate of Law, Associate Professor at the Department of Criminalistics and Forensic Medicine, National Academy of Internal Affairs

absord@ukr.net

Doctor of Juridical Sciences, Associate Professor, Professor at the Department of Administration and Informational Law, Institute of Jurisprudence, Psychology and Innovative Education of Lviv Polytechnic National University

blikharm@ukr.net

Candidate of Law, Associate Professor, Associate Professor at the Department of Criminology, Yaroslav Mudryi National Law University

chernygennadiy@gmail.com

Postgraduate Student at the Department of Jurisprudence and Branch Legal Disciplines, National Pedagogical Dragomanov University

paluch84@ukr.net

Postgraduate Student at the Department of Criminalistics and Forensic Medicine, National Academy of Internal Affairs tymoshenko_k@ukr.net

Doctor of Economic Sciences, Professor, Academician of National Academy of Agrarian Sciences of Ukraine, Head of the Department of Administrative Management and Alternative Energy Sources, Vinnytsia National Agrarian University

rector@vsau.org

Candidate of Law, Associate Professor at the Department of International and European Law, Faculty of International Legal Relations, National University "Odessa Law Academy" roman2012h@gmail.com

Candidate of Law, Associate Professor at the Department of Jurisprudence and Branch Legal Disciplines Socio-Legal Faculty, National Pedagogical Dragomanov University valentina_kv@ukr.net

Candidate of Law, Associate Professor at the Department of Theory and History of the State and Right Socio-Legal Faculty, National Pedagogical Dragomanov University Elena_k_v@ukr.net

Postgraduate student at the Department of Administrative Law and Procedure and Customs Security, University of the State Fiscal Service of Ukraine natali410@gmail.com

VI year student, Institute of Forensic Science of Yaroslav Mudryi National Law University sregina302@gmail.com 
SYZONENKO ANTON STEPANOVYCH

TEREKHOV VITALY

YURIEVICH

TOMLYAK TAISA

SERHIIVNA

ZAIATS OLHA

STEPANIVNA

ZYTSYK SERHIY

HRYHOROVYCH

OPOLSKAYA NATALYA

MYKHAILIVNA
Candidate of Law, Associate Professor, Honored Lawyer of Ukraine, First Deputy Director of the Personnel Department of the Ministry of Internal Affairs of Ukraine

my.post@meta.ua

Candidate of Law, Lawyer

terehov_dok@ukr.net

Graduate Student at the Department of Theory and History of State and Law of National Pedagogical Dragomanov University, Senior Lecturer at the Department of Law, Vinnytsia National Agrarian University

tomlak.taya@gmail.com

Candidate of Juridical Sciences, Associate Professor at the Department of Civil Law Disciplines, Lviv State University of Internal Affairs Ukraine

zaiatsolha777@gmail.com

Candidate of Law, Associate Professor at the Department of Law, Lutsk National Technical University

sergeypravo@i.ua

Doctor of Law, Associate Professor, Head of the Department of Law, Vinnytsia National Agrarian University

Opolska@vsau.org 


\section{MICT}

Антощук А. О., Гриненко К. В.

ОСОБЛИВОСТІ ПРЕД' ЯВЛЕННЯ ОСОБИ ДЛЯ ВПІЗНАННЯ

ЗА МАТЕРІАЛАМИ ВІДЕОЗАПИСУ.

Бліхар M. M.

ПУБЛІЧНИЙ ІНТЕРЕС В АДМІНІСТРАТИВНОМУ ПРАВІ.

Буковинська Н. А.

НАПРЯМИ УДОСКОНАЛЕННЯ ОРГАНІЗАЦИЙНОГО ТА ПРАВОВОГО ЗАБЕЗПЕЧЕННЯ

ГЕНДЕРНОЇ ПОЛІТИКИ В УКРАЇНІ.

Глущенко М. П.

РОЛЬ ПРОФСПІЛОК У ЗАХИСТІ ТРУДОВИХ ПРАВ

В УМОВАХ РОЗВИТКУ ЦИФРОВОЇ ЕКОНОМІКИ.

Заяць О. C.

ІНТЕНЦІОНАЛЬНИЙ АНАЛІЗ СВІТОГЛЯДНИХ ОЗНАК ПРОФЕСІЙНОЇ

АДВОКАТСЬКОЇ ДІЯЛЬНОСТІ.

Зицик $\boldsymbol{C}$. $\Gamma$.

ПРАВОВИЙ РЕЖИМ ІНФОРМАЦІЇ ПРО ПЛАТНИКІВ ПОДАТКІВ В УКРАЇНІ 38

Калетнік Г. М., Опольська Н. М.

НАБУТТЯ ПРАВА ВЛАСНОСТІ НА ЗЕМЕЛЬНІ ДІЛЯНКИ СІЛЬСЬКОГОСПОДАРСЬКОГО ПРИЗНАЧЕННЯ В УКРАЇНІ В РОЗРІЗІ ПРЕЦЕДЕНТНОЇ ПРАКТИКИ

ЄВРОПЕЙСЬКОГО СУДУ ІЗ ПРАВ ЛЮДИНИ.

Кончаковська В. В., Макарова О. В.

ПРИЧИНИ ФОРМУВАННЯ КРИМІНОГЕННОЇ ПОВЕДІНКИ У НЕПОВНОЛІТНІХ. .54

Сизоненко А. С.

ПРОФІЛАКТИКА ЮВЕНАЛЬНОЇ КРИМІНАЛЬНО ПРОТИПРАВНОЇ ДІЯЛЬНОСТІ

ЯК ПРОВІДНИЙ МІЖНАРОДНИЙ СТАНДАРТ ЗАПОБІГАННЯ

КРИМІНАЛІЗАЦІЇ НЕПОВНОЛІТНІХ

Терехов В. Ю.

НОРМАТИВНО-ПРАВОВИЙ АНАЛІЗ РОБОТИ ПРАВООХОРОННИХ ОРГАНІВ

В УМОВАХ НЕСПРИЯТЛИВОЇ ЕПІДЕМІОЛОГІЧНОЇ СИТУАЦІЇ

(НА ПРИКЛАДІ ПРОТИДІЇ ГОСТРІЙ РЕСПІРАТОРНІЙ ХВОРОБІ COVID-19).

.65

Томляк Т. С.

ГЕНЕЗИС ПРИНЦИПУ ЗАБЕЗПЕЧЕННЯ НАЙКРАЩИХ ІНТЕРЕСІВ ДИТИНИ

В МІЖНАРОДНОМУ ПРАВІ.

Харитонов Р. Ф.

МІЖНАРОДНО-ПРАВОВИЙ АСПЕКТ ВІДНОСИН МІЖ УКРАЇНОЮ ТА США (1991-1994 РР.) .81

ЧорНИЙ Г. О., Савченко Р. I.

ДО ПОСТАНОВКИ ПИТАННЯ ЩОДО ПРОФЕСІЙНОЇ ДЕФОРМАЦІЇ ПРАЦІВНИКІВ

НАЦІОНАЛЬНОЇ ПОЛІЦІЇ УКРАЇНИ ЯК ОДНІЄЇ З ПРИЧИН ПОРУШЕННЯ ПРАВ ЛЮДИНИ

ТА ЗАСТОСУВАННЯ НАСИЛЬСТВА.

Чорний Г. О.

ОСОБЛИВОСТІ ЗАСТОСУВАННЯ ГЕНЕТИЧНОГО ФІНГЕРПРИНТА

ПІД ЧАС РОЗСЛІДУВАННЯ ЗЛОЧИНІВ ТЕРОРИСТИЧНОЇ СПРЯМОВАНОСТІ. 97

НАШІ АВТОРИ. .103 


\section{CONTENTS}

Antoshchuk A. O., Hrynenko K. V.

FEATURES OF PRESENTATION A PERSON FOR IDENTIFICATION BY VIDEO MATERIALS. 3

Blikhar M. M.

PUBLIC INTEREST IN ADMINISTRATIVE LAW.....

Bukovynska N. A.

DIRECTIONS OF IMPROVEMENT OF ORGANIZATIONAL AND LEGAL SUPPORT

OF GENDER POLICY IN UKRAINE.

Gluschenko M. P.

THE ROLE OF TRADE UNIONS IN PROTECTING LABOUR RIGHTS IN THE DIGITAL ECONOMY .....24

Zaiats $\boldsymbol{O}$. $S$.

INTENTIONAL ANALYSIS OF WORLD VIEWS OF PROFESSIONAL ADVOCACY.

.32

Zytsyk S. $H$.

LEGAL REGIME OF INFORMATION ON TAXPAYERS IN UKRAINE.

.38

Kaletnik H. M., Opolska N. M.

ACQUISITION OF OWNERSHIP OUT OF AGRICULTURAL LAND IN UKRAINE

IN THE CONCERN OF CASE PRACTICE OF THE EUROPEAN COURT OF HUMAN RIGHTS.

Konchakovska $V . V$., Makarova $O . V$.

REASONS FOR THE FORMATION OF CRIMINOGENIC BEHAVIOR IN MINORS.

Syzonenko A. S.

PREVENTION OF JUVENILE CRIMINAL ACTIVITY AS A LEADING INTERNATIONAL

STANDARD FOR THE PREVENTION OF JUVENILE DELINQUENCY.

Terekhov $\mathrm{V}$. Yu.

LEGAL REGULATION OF LAW ENFORCEMENT AUTHORITIES ACTIVITIES

IN THE CONDITIONS OF AN ADVERSE EPIDEMIOLOGICAL SITUATION

(ON THE EXAMPLE COMBATING ACUTE RESPIRATORY DISEASE COVID-19).

\section{Tomliak T.S.}

GENESIS OF THE PRINCIPLE OF ENSURING THE BEST INTERESTS

OF THE CHILD IN INTERNATIONAL LAW.

Kharytonov $\boldsymbol{R}$. $\boldsymbol{F}$.

INTERNATIONAL LEGAL ASPECT OF RELATIONS BETWEEN UKRAINE

AND THE UNITED STATES (1991-1994).

Chornyi H. O., Savchenko R. I.

PROBLEM STATEMENT OF PROFESSIONAL DEFORMATION OF POLICE OFFICERS

OF THE NATIONAL POLICE OF UKRAINE AS A CAUSE

OF HUMAN RIGHTS VIOLATION AND USE OF FORCE.

Chornyi G. $O$.

THE FEATURES OF THE USE OF GENETIC FINGERPRINTING IN THE INVESTIGATION

OF TERRORIST CRIMES. 


\section{НОТАТКИ}




\title{
НАУКОВИЙ ЧАСОПИС НАЦІОНАЛЬНОГО ПЕДАГОГІЧНОГО УНІВЕРСИТЕТУ IМЕНІ М. П. ДРАГОМАНОВА
}

\author{
Серія 18. Право
}

Випуск 36

Матеріали подані мовою оригіналу

Автори опублікованих матеріалів несуть повну відповідальність за підбір, точність наведених фактів, цитат, економіко-статистичних даних, власних імен та інших відомостей.

\author{
Підписано до друку 23.12.2021. \\ Формат 60x84/8. Гарнітура Times New Roman. \\ Папір офсет. Цифровий друк. Ум.-друк. арк. 12,79. Обл.-вид. арк. 10,30. \\ Замов. № 0122/007. Наклад 300 прим. \\ Віддруковано з оригіналів \\ Видавничий дім «Гельветика» \\ 73021, м. Одеса, вул. Інглезі, 6/1 \\ Телефон +38 (0552) 3995 80, +38 (095) 93448 28, +38 (097) 7230608 \\ E-mail: mailbox@helvetica.ua \\ Свідоцтво суб'єкта видавничої справи \\ ДК № 6424 від 04.10.2018 p.
}

